OMAR GOMES FILHO

INFLUÊNCIA DA CORRENTE ELÉTRICA, DA FORÇA DE RECALQUE E DO TRATAMENTO TÉRMICO DE REVENIMENTO NA SOLDAGEM TOPO-ATOPO POR CENTELHAMENTO DE SERRAS DE FITA BIMETÁLICA

Dissertação apresentada à Escola Politécnica da Universidade de São Paulo para a obtenção do título de Mestre em Engenharia.

São Paulo 
OMAR GOMES FILHO

\section{INFLUÊNCIA DA CORRENTE ELÉTRICA, DA FORÇA DE RECALQUE E DO TRATAMENTO TÉRMICO DE REVENIMENTO NA SOLDAGEM TOPO-A- TOPO POR CENTELHAMENTO DE SERRAS DE FITA BIMETÁLICA}

Dissertação apresentada à Escola Politécnica da Universidade de São Paulo para a obtenção do título de Mestre em Engenharia.

Área de Concentração:

Engenharia Metalúrgica e de Materiais

Orientador:

Prof. Dr. Sérgio Duarte Brandi

São Paulo 
Este exemplar foi revisado e alterado em relação à versão original, sob responsabilidade única do autor e com a anuência de seu orientador.

São Paulo, 18 de setembro de 2007.

Autor: Omar Gomes Filho

Orientador: Prof. Dr. Sérgio Duarte Brandi

\section{Ficha catalográfica}

\section{Omar Gomes Filho.}

Influência da corrente elétrica, da força de recalque e do tratamento térmico de revenimento na soldagem topo-a-topo por centelhamento de serras de fita bimetálica / Omar Gomes Filho - São Paulo, 2007.

$211 \mathrm{p}$.

Dissertação (Mestrado) - Escola Politécnica da Universidade de São Paulo. Departamento de Engenharia Metalúrgica e de Materiais.

1. Soldagem topo-a-topo. 2. Soldabilidade. 3 Aços baixa liga.

I. Universidade de São Paulo. Escola Politécnica. Departamento de Engenharia Metalúrgica e de Materiais. II. D 
Dedico este trabalho, à minha esposa, a psicóloga Zilda Lúcia Carneiro de Carvalho, e às minhas filhas Gabriella e Ana Beatriz Gomes de Carvalho, pelo grande apoio, carinho e compreensão, que foram essenciais para o desenvolvimento e conclusão desta dissertação. 
Ofereço esta dissertação aos meus pais Omar Gomes de Carvalho e Maria Nazareth Coura Carvalho, pelo exemplo de vida, pela base educacional e pelo constante apoio e incentivo ao desenvolvimento deste trabalho. 
O compromisso abre as portas da imaginação, e nos dá a capacidade de sonhar e o "material certo" para transformar os nossos sonhos em realidade.

James Womack 


\section{AGRADECIMENTOS}

Ao Prof. Dr. Sérgio Duarte Brandi por me acolher na Escola Politécnica da Universidade de São Paulo, ensinar-me os fundamentos de um trabalho científico, orientar-me de maneira excepcional durante todo o período de atividades e pela confiança depositada.

Ao MSc. Erni Dattein - Gerente Geral da empresa Wagner Lennartz do Brasil Indústria e Comércio de Serras Ltda. - pelo apoio irrestrito a esta pesquisa, pelo fornecimento dos materiais e equipamentos para execução da soldagem e pelas sugestões que muito auxiliaram no desenvolvimento deste trabalho.

Ao Prof. Dr. Amilton Sinatora do Departamento de Engenharia Mecânica da EPUSP, que permitiu a execução dos ensaios de dureza no laboratório LFS e ao Técnico Jovanio de Oliveira Santos, que me ensinou a utilizar o durômetro e proveu todo o suporte necessário durante a realização dos ensaios.

Ao Prof. Dr. Hercílio Rechenberg e ao físico Renato Cohen do Instituto de Física da Universidade de São Paulo, que muito gentilmente se prontificaram à execução e análise dos ensaios de Espectroscopia Mossbauer.

Ao Vinicius Freire Elias - Técnico do Laboratório MEV do Departamento de Engenharia Metalúrgica e de Materiais da EPUSP - pela execução das microfotografias de fraturas e análises EDS.

Ao Cláudio Roberto dos Santos - Técnico do Laboratório de Metalografia do Departamento de Engenharia Metalúrgica e de Materiais da EPUSP - que desenvolveu o procedimento para os ataques químicos, bem como proveu todo o suporte durante a fase de caracterização microestrutural. 
Aos colegas da EPUSP Dr. Wanderson Santana da Silva e doutorando Abel André Recco, pela preciosa ajuda na discussão dos resultados e ao mestrando Mário Gonzalez Ramirez, pelo grande apoio ao uso dos equipamentos do laboratório metalográfico e armazenagem das amostras em vácuo.

À empresa Testin - Tecnologia de Materiais Ltda. - Vila Mariana - SP, pela preciosa colaboração na execução dos ensaios de tração. Em especial à Sra. Duleina Andreone de Lima Diretora Comercial, Sr. Nelson Jesus Martinez - Diretor Presidente, Sr. Luiz Antônio Fernandes Sant'Ana - Diretor Técnico e ao Sr. Manoel Messias Brilhante - Técnico do Laboratório de Ensaios Mecânicos.

Ao Sr. Harri Soares, Diretor da empresa Ferhari - Dispositivos para Automação Industrial Diadema - SP, pela importante colaboração no corte dos corpos de prova para ensaios de tração pelo processo de eletro-erosão a fio.

Ao colega José Ramalho - doutorando na EPUSP, pelo empréstimo de livros, sugestões de idéias para execução dos ensaios e grande apoio durante a execução dos testes práticos.

Ao Flávio Gil - colega de mestrado na EPUSP, pela traçagem dos corpos de prova para ensaios de tração e determinação das áreas fraturadas dos corpos de prova de torção em equipamento estereoscópico do Laboratório de Junção do Departamento de Engenharia Metalúrgica e de Materiais da EPUSP.

Ao Sr. Dieter Lasarz - Gerente de Engenharia da empresa Ideal Werk da Alemanha, pelas importantes informações transmitidas sobre o processo de soldagem topo-a-topo por centelhamento e funcionamento do equipamento de soldagem.

Ao Sr. Christoph Peter - Gerente de Qualidade da empresa Wespa Metallsägefabrik da Alemanha, pelas valiosas informações sobre os requisitos de qualidade da junta soldada de serras de fita bimetálica pelo processo topo-a-topo por centelhamento. 
À Simonds International - USA, em especial Sr. Edward Lashua - Especialista em Soldagem de Serras de Fitas, Sr. Bill Logan - Chefe do Laboratório Metalográfico e Sr. Sal Santoro - Gerente de Qualidade e de Engenharia, pelas importantes informações e esclarecimentos transmitidos, que muito ajudaram na execução deste trabalho.

A todos os colegas de trabalho da empresa Wagner Lennartz, que participaram direta e indiretamente deste trabalho, com destaque para o Eng $^{\mathrm{o}}$ Jéferson Luis da Silva, que elaborou os desenhos deste trabalho, Valdenir Rodrigues da Silva que fez o corte e embutimento dos corpos de prova para metalografia, Daniel Antônio da Silva que ajudou na medição do alongamento dos corpos de prova de tração, Sr. Altair Miato pelas importantes informações sobre análises metalográficas e ao $\mathrm{Eng}^{\mathrm{o}}$ Ricardo Portella de Souza, pelos importantes ensinamentos a respeito do uso do equipamento de soldagem topo-a-topo por centelhamento e pela colaboração na soldagem dos corpos de prova.

Ao Gilberto Martins e Clélia Meguerditchian da Biblioteca do Departamento de Engenharia Metalúrgica e de Materiais da EPUSP, pelo apoio ao uso da biblioteca e na obtenção de materiais para pesquisas.

Ao Eng ${ }^{\circ}$ Gérson Bianco Alonso - Gerente Comercial da empresa Demag Cranes \& Components Ltda., que autorizou e deu amplo apoio ao início deste trabalho de mestrado no período de curso das disciplinas. 


\section{CURRICULUM VITAE}

\section{OMAR GOMES FILHO}

NASCIMENTO:

1960, Delfim Moreira-MG, Brasil.

\section{FORMAÇÃO ACADÊMICA:}

1979 - 1983 Formação em Engenharia Mecânica - Universidade de Taubaté - Taubaté - SP.

1993 - 1994 Pós-graduação em Administração Industrial - Fundação Vanzolini - EPUSP.

1995 - 1996 Pós-graduação em Qualidade e Produtividade - Fundação Vanzolini - EPUSP.

\section{EXPERIÊNCIA PROFISSIONAL:}

1984 - 2004 Demag Cranes \& Components Ltda.

- Engenheiro de Controle de Qualidade.

- Supervisor de Nacionalização e Projetos de Dispositivos.

- Supervisor de Montagem Externa de Equipamentos.

- Supervisor de Produção.

2004 - Atual Wagner Lennartz \& Simonds International Ltda.

- Gerente de Projetos para implantação de uma fábrica de serras de fitas.

- Gerente Industrial.

\section{TRABALHO SUBMETIDO:}

GOMES FILHO, O.; BRANDI, S.D. Efeitos da corrente elétrica, da força de recalque e do tratamento de revenimento na soldagem topo-a-topo por centelhamento de serras de fita bimetálica. XXXIII Congresso Nacional de Soldagem, Caxias do Sul, RS, Agosto, 2007. 


\section{SUMÁRIO}

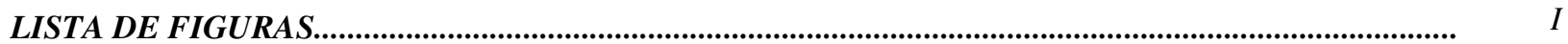

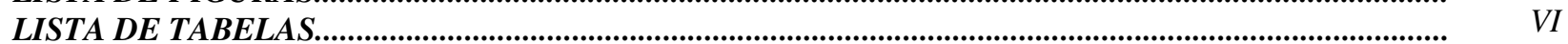

LISTA DE ABREVIATURAS

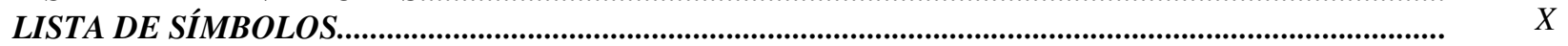

RESUMO

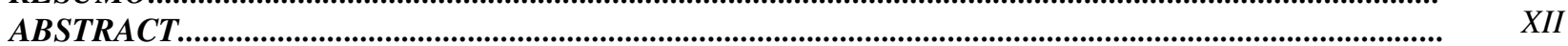

1. INTRODUÇÃ

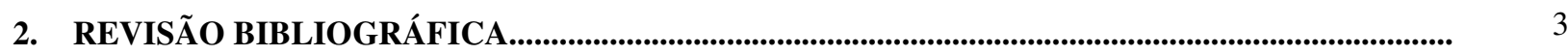

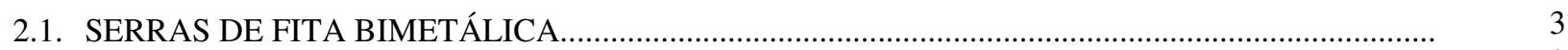

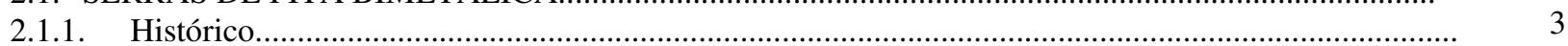

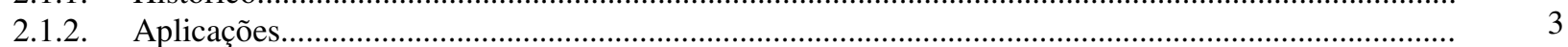

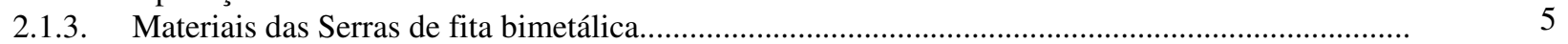

2.1.3.1. Fitas Bimetálicas para Serras de Fitas............................................................................................ 5

2.1.4. Processo de Fabricação das Fitas Bimetálicas...............................................................................

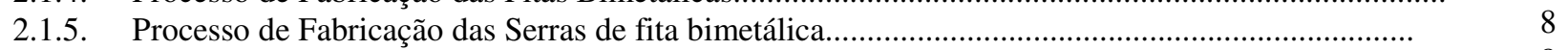

2.1.5.1. Tratamento Térmico de Têmpera e Revenimento das Serras de fita bimetálica................................

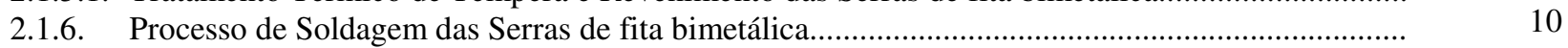

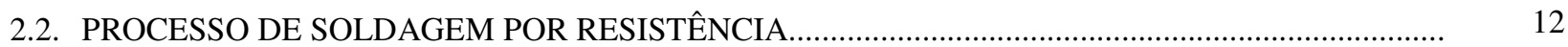

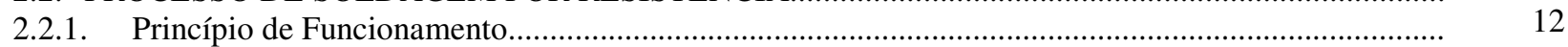

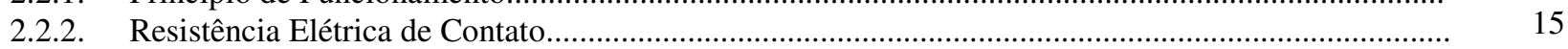

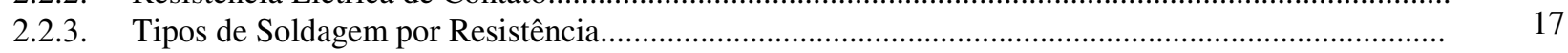

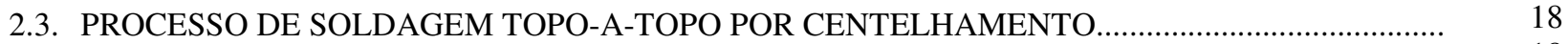

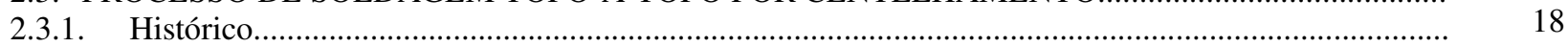

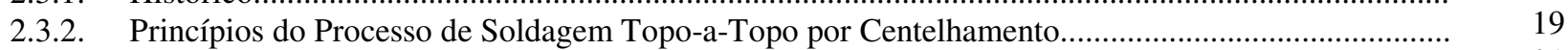

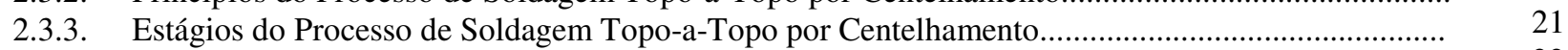

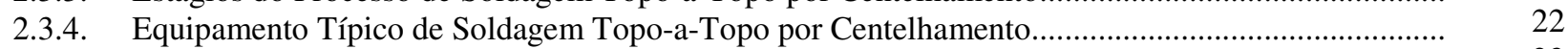

2.3.5. Descrição do Processo de Soldagem Topo-a-Topo por Centelhamento para Serras de Fita................... 23

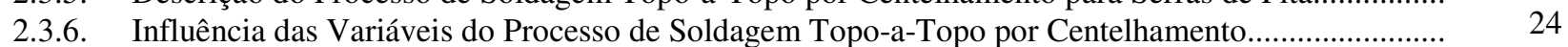

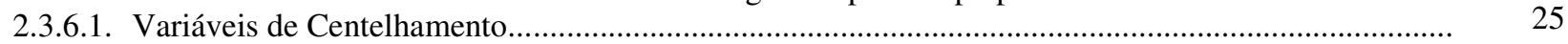

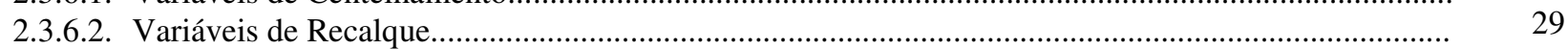

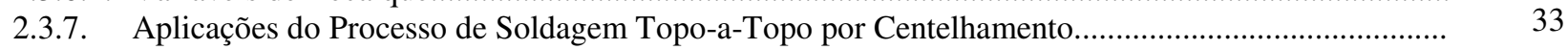

2.4. CARACTERÍSTICAS METALÚRGICAS DAS SOLDAS TOPO-A-TOPO POR

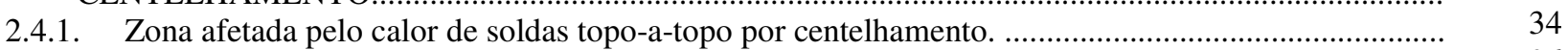

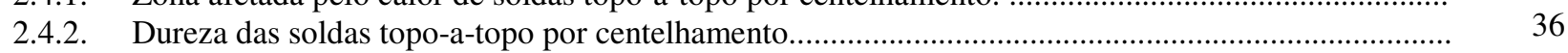

2.5. REVENIMENTO DAS SOLDAS TOPO-A-TOPO POR CENTELHAMENTO..................................... 38

2.6. PROPRIEDADES DAS JUNTAS SOLDADAS TOPO-A-TOPO POR CENTELHAMENTO..................42

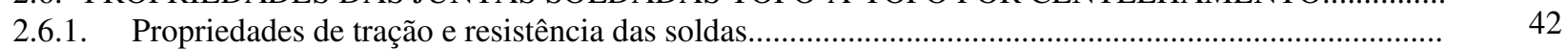

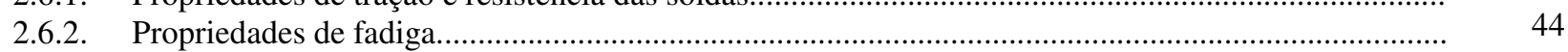

2.7. QUALIDADE DAS SOLDAS TOPO-A-TOPO POR CENTELHAMENTO.............................................

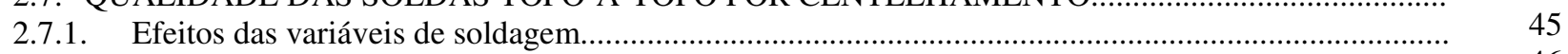

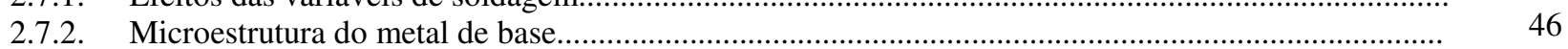

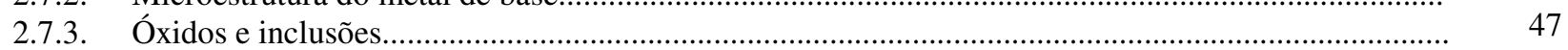




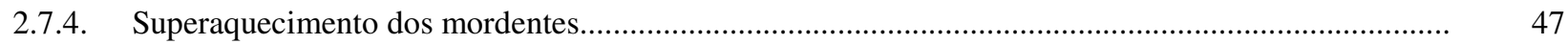

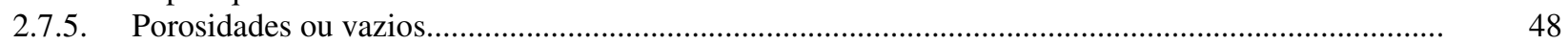

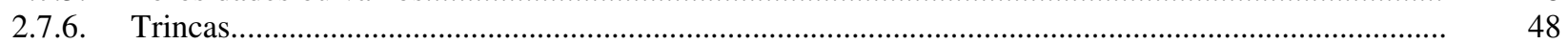

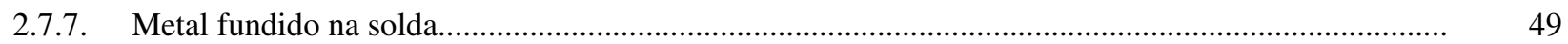

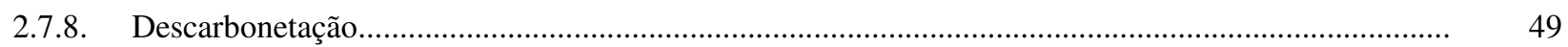

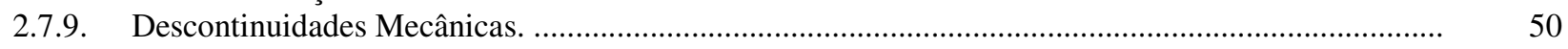

2.8. AÇOS DE BAIXA LIGA E MÉDIO TEOR DE CARBONO............................................................. 50

2.8.1. Aços de alta resistência, baixa liga e médio teor de carbono.......................................................... 51

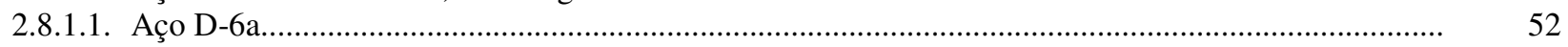

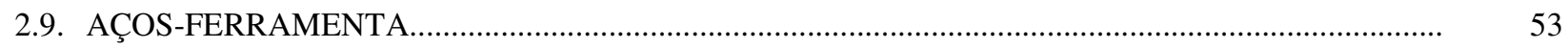

2.9.1. Efeitos dos elementos de liga nos aços ferramentas....................................................................

2.9.2. Classificação dos aços ferramentas.......................................................................................... 55

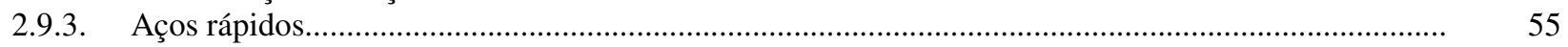

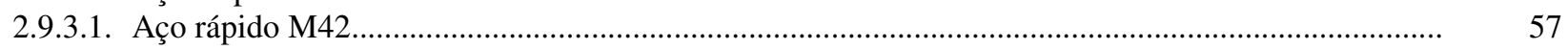

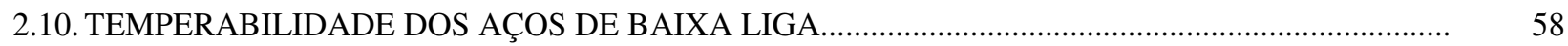

2.10.1. Transformações Microestruturais nos aços de baixa liga...................................................................... 58

2.10.2. Efeitos do tratamento térmico no aço D-6a................................................................................... 59

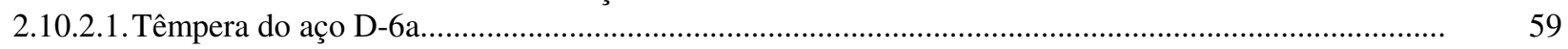

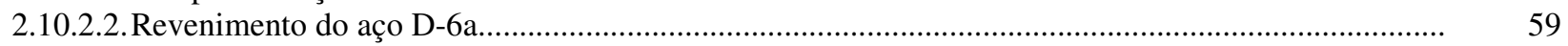

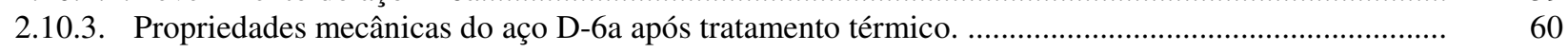

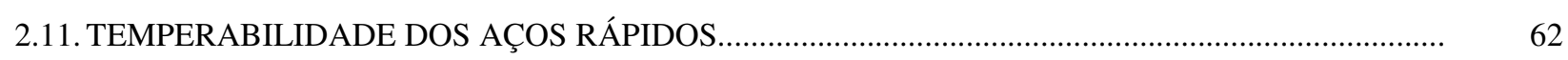

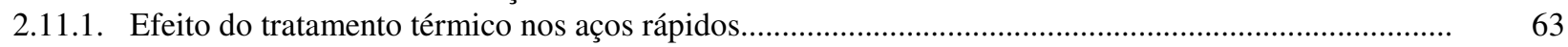

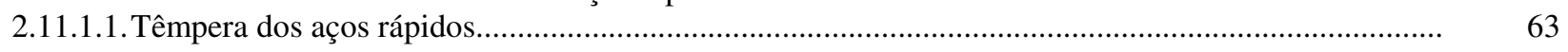

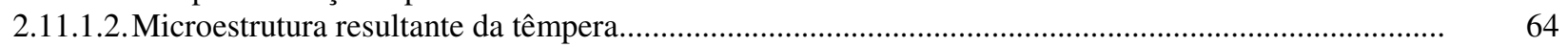

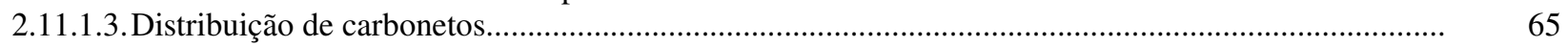

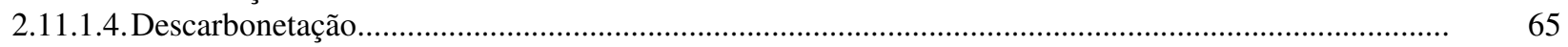

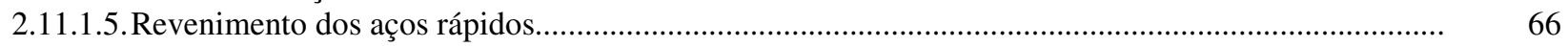

2.12. METALURGIA DA SOLDAGEM DOS AÇOS DE BAIXA LIGA E AÇOS-FERRAMENTA............. 67

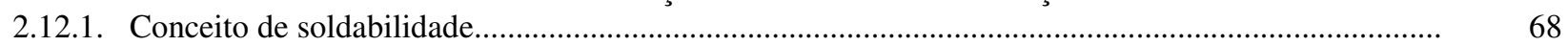

2.12.2. Soldabilidade dos aços de baixa liga.. $\quad 69$

2.12.2.1. Transformações metalúrgicas na soldagem dos aços de baixa liga..................................................... 71

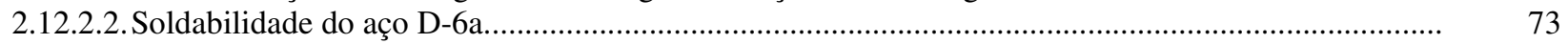

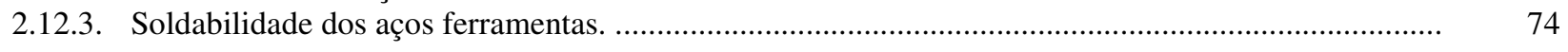

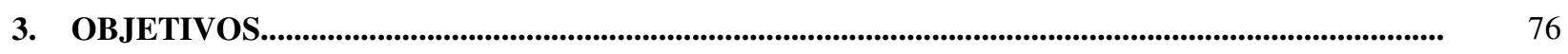

4. MATERIAIS E MÉTODOS............................................................................................................................

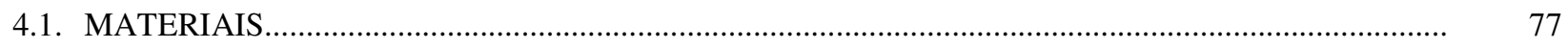

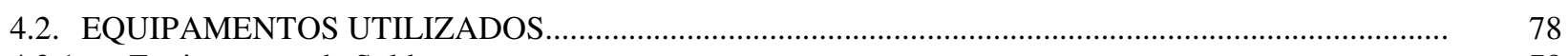

4.2.1. Equipamento de Soldagem.....................................................................................................

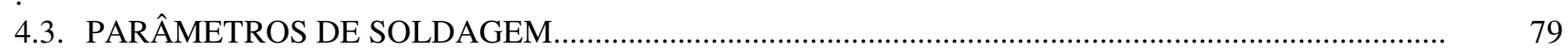

4.3.1. Parâmetros de soldagem recomendados para serras de fitas de $27 \mathrm{~mm}$ de largura............................... 79

4.3.2. Parâmetros de soldagem testados para serras de fitas de $27 \mathrm{~mm}$ de largura......................................... 80

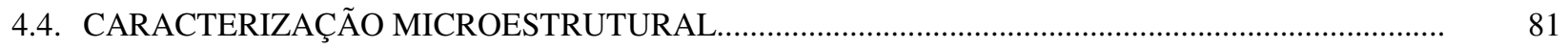

4.4.1. Critérios para retirada dos corpos de prova................................................................................. 82

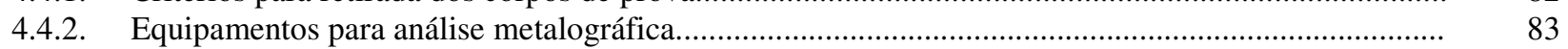

4.4.3. Equipamentos para Espectroscopia Mossbauer.......................................................................... 
4.5. ENSAIOS MECÂNICOS PARA AVALIAÇÃO DA JUNTA SOLDADA................................................

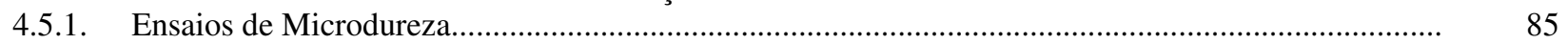

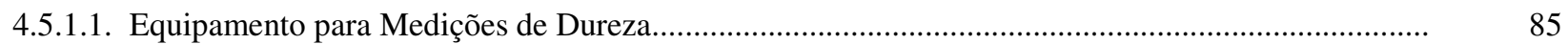

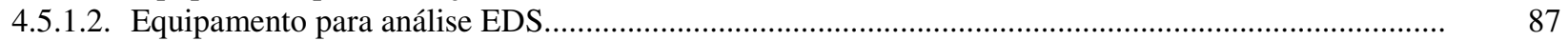

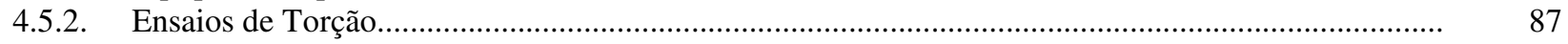

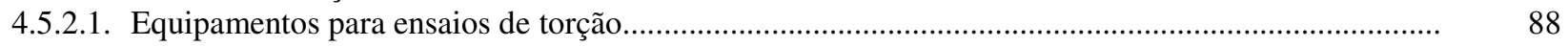

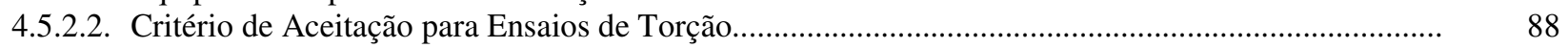

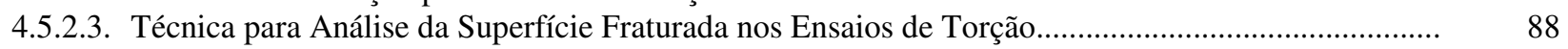

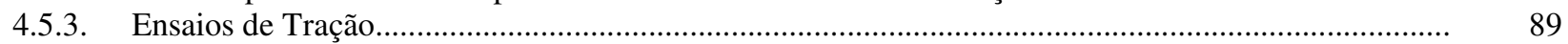

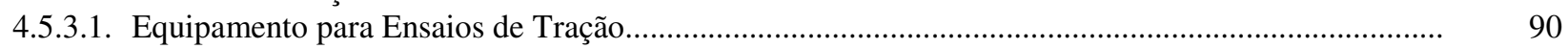

4.5.3.2. Técnica para Análise da Superfície Fraturada nos Ensaios de Tração.................................................. 90

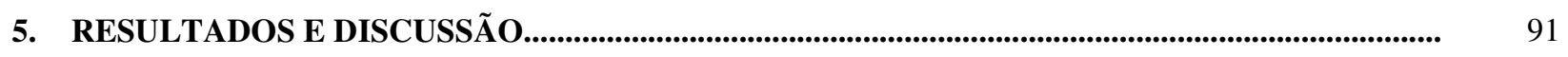

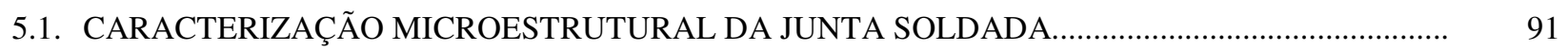

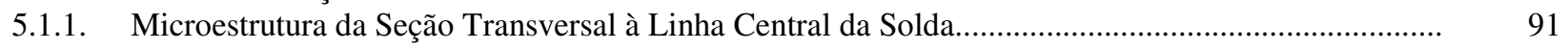

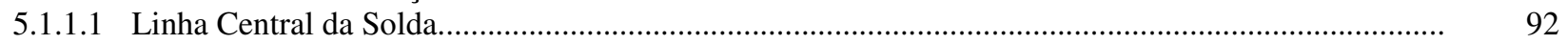

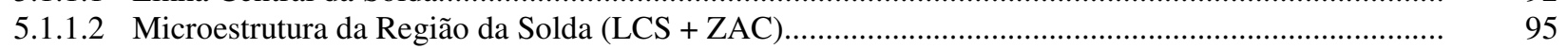

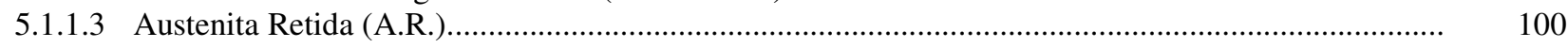

5.1.1.4 Defeitos na região da solda (LCS + ZAC) ................................................................................... 102

5.1.1.5 Linhas de fluxo de material na região da solda (LCS + ZAC) ..................................................... 102

5.1.2 Microestrutura da Seção Longitudinal à Linha Central da Solda........................................................ 104

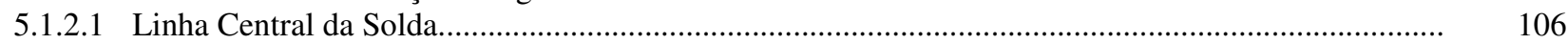

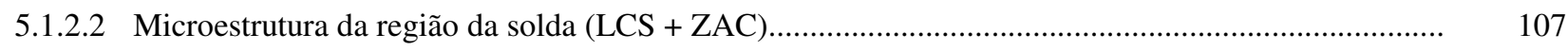

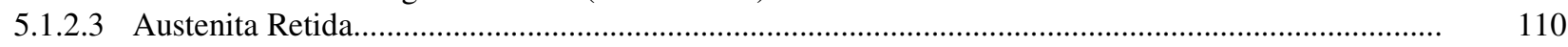

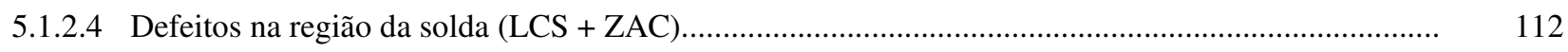

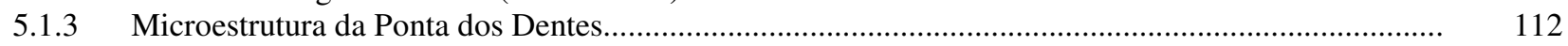

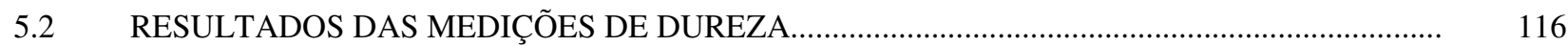

5.2.1 Critério de Medição da Dureza nas Amostras...................................................................................... 116

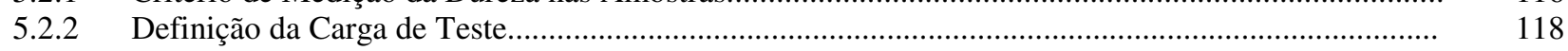

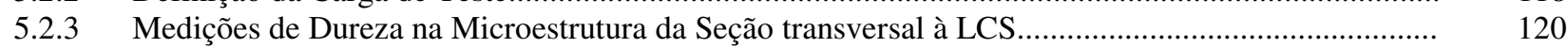

5.2.3.1 Variação da Dureza na LCS em Função da Variação da Corrente Elétrica.............................................. 121

5.2.3.2 Variação da Dureza na LCS em Função da Variação da Força de Recalque......................................... 125

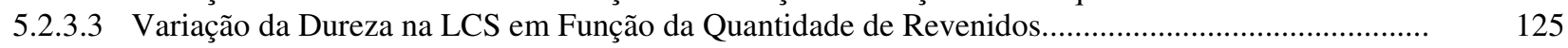

5.2.3.4 Variação da Dureza na LCS em Função da Temperatura de Revenido................................................ 130

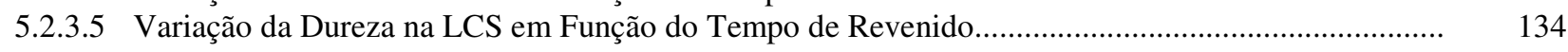

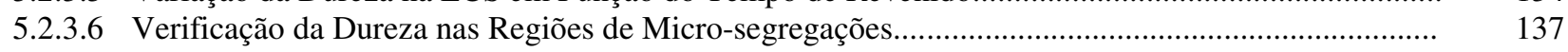

5.2.3.7 Verificação da Composição Química por EDS nas Regiões de Micro-segregações.............................. 140

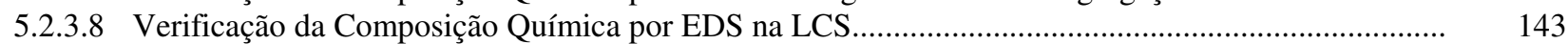

5.2.3.9 Verificação da Dureza na região de austenita retida.......................................................................

5.2.3.10 Verificação da Dureza na ZAC e MB em relação à LCS......................................................................

5.2.4 Medições de Dureza na Microestrutura da Seção Longitudinal à LCS.................................................. 147

5.2.4.1 Comparação de Dureza da Seção Transversal e Longitudinal à LCS................................................... 151

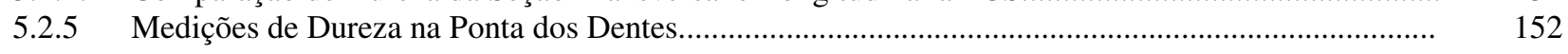

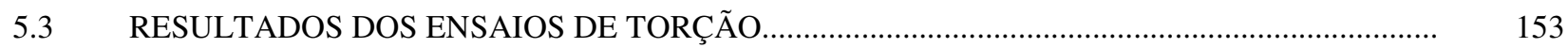

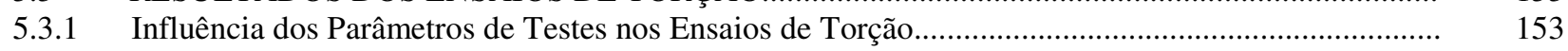

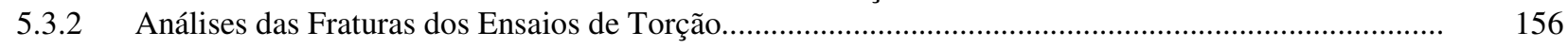

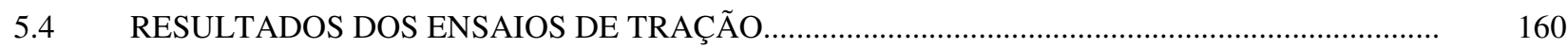

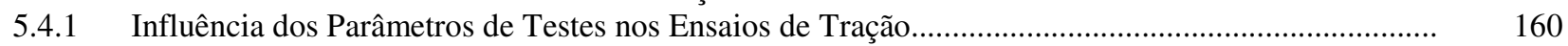

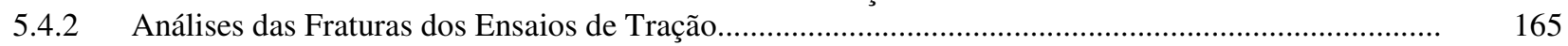


5.5 RESUMOS DOS PRINCIPAIS RESULTADOS CONSIDERANDO-SE OS PARÂMETROS DE SOLDAGEM ESTUDADOS

5.5.1 Verificação do Aumento de Produtividade com Parâmetro E1.

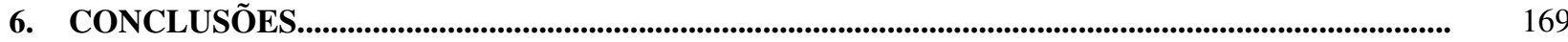

7. SUGESTÕES PARA TRABALHOS FUTUROS.................................................................................. 174

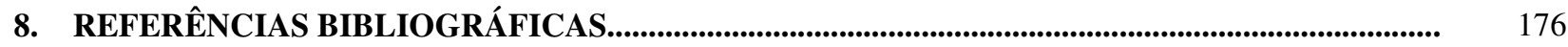

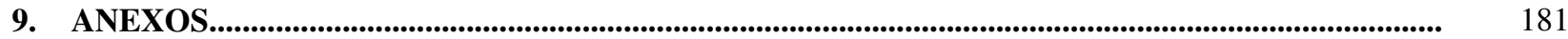




\section{LISTA DE FIGURAS}

Figura 1.1 Dados do mercado mundial de serras de fita - 2007.

Figura 2.1 Exemplos de aplicações de serras de fita bimetálica.

Figura 2.2 Diagrama esquemático mostrando os componentes das fitas bimetálicas e seu respectivo processo de fabricação: A - corpo da fita em aço carbono de baixa liga e alta resistência; $\mathrm{B}$ - fita de aço rápido; $\mathrm{C}$ - solda por feixe de elétrons.

Figura 2.3 Microestrutura da ponta de um dente de serra de fita $27 \mathrm{~mm}-3 / 4$ em aço rápido M42, mostrando carbonetos uniformes e bem distribuídos em matriz martensítica revenida fina, isenta de austenita retida e de descarbonetação.

Figura 2.4 Microestrutura do corpo de uma serra de fita $27 \mathrm{~mm}$ - 4/6 em aço carbono de alta resistência e baixa liga D-6a, mostrando martensita revenida fina.

Figura 2.5 Diagrama esquemático mostrando a posição da solda topo-a-topo por centelhamento da serra de fita.

Figura 2.6 Esquema mostrando as resistências dos componentes no processo de soldagem por resistência elétrica a ponto.

Figura 2.7 Etapas básicas na soldagem topo-a-topo por centelhamento: (A) posicionamento e fixação das peças; (B) aplicação da tensão de centelhamento e início do deslocamento da porta-eletrodo móvel; (C) centelhamento; (D) Desligamento da corrente e aplicação da força de recalque.

Figura 2.8 Diagrama esquemático de um ciclo de soldagem por centelhamento.

Figura 2.9 Diagrama esquemático de um equipamento de soldagem topo-a-topo por centelhamento.

Figura 2.10 Variação de dureza na ZAC e no metal de base para juntas soldadas por centelhamento em: (a) aço carbono de baixo teor de carbono laminado a frio e (b) um aço ligado ao Cr-Ni-Mo.

Figura 2.11 Efeitos do tempo na redução da dureza de aços temperados com $0,35 \% \mathrm{C}$ em quatro diferentes temperaturas de revenimento.

Figura 2.12 Variação da dureza com o aumento da temperatura em aços com 5\% de cromo contendo $0,35 \%$ de carbono e molibdênio em teores variáveis.

Figura 2.13 Gráficos de dureza transversal para soldas por centelhamento típicas. (a) conforme soldado. (b) normalizado e revenido após soldagem. Mesmas condições de soldagem para (a) e (b).

Figura 2.14 Linhas de fluxo de metal e rebarbas típicas de uma solda topo-a-topo por centelhamento.

Figura 2.15 Tenacidade à baixas temperaturas do aço D-6a. Todos os corpos de prova foram tratados termicamente até uma resistência à tração à temperatura ambiente de 1790 a $1860 \mathrm{MPa}$. 
Figura 2.16 Variação da dureza com a temperatura de revenimento para o aço D-6a. Todos os corpos de prova foram temperados em óleo a $845^{\circ} \mathrm{C}$ e revenidos $2 \mathrm{~h}$ na temperatura.

Figura 2.17 Gráfico de dureza $\mathrm{x}$ temperatura de revenimento para alguns aços rápidos selecionados, após três ciclos de revenimento de 2 horas cada.

Figura 2.18 Efeito do tempo de resfriamento $\Delta \mathrm{t}_{8-5}$ na fração volumétrica da martensita em forma de lâminas dentro da ZAC de grãos grosseiros de aços de baixa liga.

Figura 2.19 Diagrama de transformação de resfriamento contínuo para o aço AISI 4340.

Figura 4.1 Desenho esquemático para retirada das amostras dos corpos de prova.

Figura 4.2 Desenho esquemático das amostras embutidas em baquelite: (a) amostra da ponta do dente de aço rápido M42; (b) amostra da seção transversal à LCS e (c) amostra da seção longitudinal à LCS.

Figura 4.3 Desenho esquemático indicando os pontos de medições de dureza em cada tipo de amostra: (a) microdureza na ponta do dente; (b) microdureza transversal à LCS e (c) microdureza longitudinal à LCS.

Figura 4.4 Desenho esquemático dos corpos de prova soldados para ensaios de torção.

Figura 4.5 Desenho esquemático para usinagem dos corpos de prova de tamanho reduzido para ensaios de tração conforme ASTM SA-370.

Figura 5.1 Microestrutura transversal à LCS da amostra E1T2 mostrando a linha clara e reta no centro da solda que é a LCS. As regiões à direita e à esquerda desta linha são as zonas afetadas pelo calor. Ataque: Villela. MO. 100X.

Figura 5.2 Microestrutura transversal à LCS da amostra B1T1 mostrando a LCS ao centro com microestrutura um pouco mais grossa que a microestrutura da ZAC. Ataque: Villela. MO. 200X.

Figura 5.3 Microestrutura transversal à LCS mostrando região da solda da amostra C1T1 que não foi revenida após soldagem, com LCS e ZAC apresentando martensita virgem. A LCS apresenta microestrutura mais grosseira em relação à ZAC. Ataque: Villela. MO. 50X, 100X e 1.000X.

Figura 5.4 Microestrutura transversal à LCS mostrando interface região da solda x metal de base da amostra A1T1. Região da solda à direita apresenta martensita revenida fina e o metal de base (corpo da serra de fita que não foi soldado) à esquerda apresenta martensita revenida mais grosseira. Ataque: Villela. MO. $50 \mathrm{X}$.

Figura 5.5 Microestrutura transversal à LCS da amostra A1T1 mostrando LCS com martensita revenida mais fina em relação ao metal de base. Ataque: Villela. MO. 200X.

Figura 5.6 Microestrutura transversal à LCS da amostra A1T1 mostrando ZAC com martensita revenida mais fina em relação ao metal de base. Ataque: Villela. MO. 200X. 
Figura 5.7 Metal de base da serra de fita fora da região da solda. Amostra A1T1 extraída transversalmente à linha central da solda. Microestrutura constituída por martensita revenida mais grosseira em relação à região da solda. Ataque: Villela. MO. Aumento: 500X.

Figura 5.8 Amostra C1T2 extraída transversalmente à linha central da solda., mostrando interface solda/metal de base. A microestrutura de cor clara é a região da solda e a escura é o metal de base (corpo da serra de fita). Ataque: Villela. MO. Aumento: 50X, 100X e 200X.

Figura 5.9 Microestrutura transversal à LCS da amostra D1T1 mostrando regiões esbranquiçadas da A.R. à esquerda da LCS. Ataque: Villela. MO. (a) 200X; (b) $1.000 \mathrm{X}$.

Figura 5.10 Espectroscopia Mossbauer. (a) Espectro de folha fina de ferro puro para calibração. (b) Espectro da amostra A1T1 mostrando um singleto de austenita no centro do espectro.

Figura 5.11 Microestrutura transversal à LCS da amostra A1T1 mostrando as linhas de fluxo do material na ZAC, que foram deformadas pela força de recalque no sentido contrário à LCS. Ataque: Villela. MO. (a)50X; (b)100X.

Figura 5.12 Microestrutura transversal à LCS da amostra C1T1 mostrando as linhas de fluxo do material na ZAC, que foram deformadas pela força de recalque no sentido contrário à LCS. Ataque: Villela. MO. 50X.

Figura 5.13 Microestrutura longitudinal à LCS da amostra E2L1 mostrando a linha clara e reta no centro da solda que é a LCS. As regiões à direita e à esquerda desta linha são as zonas afetadas pelo calor. A microestrutura mais grosseira a direita da ZAC é o metal de base. Ataque: Villela. MO. 50X.

Figura 5.14 Microestrutura longitudinal à LCS da amostra A3L1 mostrando a LCS ao centro com microestrutura um pouco mais grossa que a da ZAC. Ataque: Villela. MO. 200X.

Figura 5.15 Microestrutura longitudinal à LCS da amostra A2L2 mostrando ZAC a esquerda com martensita revenida mais fina que o metal de base. Ataque: Villela. MO. 100X.

Figura 5.16 Microestrutura longitudinal à LCS da amostra A3L2 mostrando ZAC a esquerda com martensita revenida mais fina em relação ao metal de base. Ataque: Villela. MO. 200X.

Figura 5.17 Microestrutura transversal à LCS da amostra A1L1 mostrando metal de base com martensita revenida mais grosseira. Ataque: Villela. MO. 500X.

Figura 5.18 Microestrutura longitudinal à LCS mostrando regiões esbranquiçadas da austenita retida próximo à LCS. Ataque: Villela. MO. (a) Amostra D1L1, 200X; (b) Amostra A1L2, 1.000X.

Figura 5.19 Microestrutura longitudinal à LCS mostrando região da solda isenta de defeitos. Amostra B3L2. Ataque: Villela. MO. 100X. 
Figura 5.20 Microestrutura da ponta do dente de aço rápido M42 mostrando carbonetos globulares e bem distribuídos em matriz martensítica isenta de austenita retida e de descarbonetação. Ataque: Villela - 7s. MO. Aumento 1.000X. (a) Amostra A2D2; (b) Amostra F1D2

Figura 5.21 Microestrutura da ponta do dente de aço rápido M42 mostrando carbonetos globulares e bem distribuídos em matriz martensítica isenta de austenita retida e de descarbonetação. Ataque: Villela - 12s. MO. Aumento 1.000X. (a) Amostra A3D1; (b) Amostra F1D2

Figura 5.22 Pontos de verificação de dureza no sentido transversal à LCS da amostra A2T2. Ataque: Villela. MO. 100X.

Figura 5.23 Pontos de verificação de dureza no sentido transversal à LCS da amostra A2T2. Ataque: Villela. MEV. 250X.

Figura 5.24 Variação da dureza em função da carga de teste. Sentido transversal à LCS.

Figura 5.25 Variação da dureza na LCS em função da variação da corrente elétrica para os parâmetros A1, A2 e A3. Sentido transversal à LCS.

Figura 5.26 Variação da dureza na LCS em função da variação da força de recalque para os parâmetros B1, B2 e B3. Sentido transversal à LCS.

Figura 5.27 Variação da dureza na LCS em função da variação da pressão de recalque. Sentido transversal à LCS.

Figura 5.28 Variação da dureza na LCS em função da variação da quantidade de revenidos para os parâmetros C1, C2 e C3. Sentido transversal à LCS.

Figura 5.29 Variação da dureza na LCS em função da variação da temperatura de revenido para os parâmetros D1, D2 e D3. Sentido transversal à LCS.

Figura 5.30 Variação da dureza na LCS em função da variação do tempo de revenido para os parâmetros E1, E2 e E3. Sentido transversal à LCS.

Figura 5.31 Determinação dos pontos sobre as linhas de fluxo claras e escuras da ZAC para execução da análise por EDS. Sentido transversal à LCS. Amostra A3T2.MEV. $800 \mathrm{X}$

Figura 5.32 Medição de microdureza na austenita retida da amostra D1L1.MEV. 200X.

Figura 5.33 Variação da dureza na LCS em função da variação da corrente elétrica para os parâmetros A1, A2 e A3. Sentido longitudinal à LCS.

Figura 5.34 Dureza média na ponta dos dentes em função de vários parâmetros de soldagem.

Figura 5.35 Superfície fraturada em ensaio de torção da amostra A23TO, mostrando região clara com característica dúctil (mecanismo alveolar) e região escura com característica frágil (mecanismo por clivagem). MEV. 40X. 
Figura 5.36 Superfície fraturada em ensaio de torção da amostra D12TO, mostrando região clara com característica dúctil (mecanismo alveolar) e região escura com característica frágil (mecanismo por clivagem). MEV. 250X.

Figura 5.37 Superfície fraturada em ensaio de torção da amostra E21TO, mostrando região clara com característica dúctil (mecanismo alveolar) e região escura com característica frágil (mecanismo por clivagem). MEV. 250X.

Figura 5.38 Superfície fraturada em ensaio de torção da amostra C12TO, mostrando fratura frágil com desvios. MEV. 40X.

Figura 5.39 Superfície fraturada em ensaio de tração do corpo de prova A21TR, mostrando fratura com aspectos frágil (ao centro) e dúctil (mais a esquerda). MEV. $5.000 \mathrm{X}$

Figura 5.40 Superfície fraturada em ensaio de tração do corpo de prova A21TR, mostrando detalhes da fratura com aspectos frágil (clivagem) circundados por alvéolos (fratura dúctil). MEV. 15.000X. 


\section{LISTA DE TABELAS}

Tabela 2.1 Composição química de algumas fitas de aço rápido e de aço carbono empregadas na fabricação de serras de fita bimetálica em \%p.

Tabela 2.2 Classificação de alguns tipos de fitas de aço rápido usadas em serras de fita bimetálica em função de seu desempenho.

Tabela 2.3 Efeitos das variáveis na qualidade das soldas por centelhamento.

Tabela 2.4 Composição química dos aços de alta resistência, baixa liga e médio teor de carbono em \%p.

Tabela 2.5 Efeito de vários elementos de ligas nas propriedades dos aços ferramentas.

Tabela 2.6 Composição química do aço rápido M42.

Tabela 2.7 Propriedades mecânicas típicas do aço D-6a em barra. Normalizado a $900^{\circ} \mathrm{C}$,

Tabela 2.8 Tabela indicativa do grau de soldabilidade de aços carbono a partir da determinação do carbono equivalente.

Tabela 4.1 Dimensões / Especificações da serra de fita bimetálica 27 mm - 4/6.

Tabela 4.2 Composição química dos materiais da serra de fita bimetálica. $27 \mathrm{~mm}$.

Tabela 4.3 Especificação de dureza para serras de fita bimetálica $27 \mathrm{~mm}$.

Tabela 4.4 Ficha técnica do equipamento de soldagem.

Tabela 4.5 Parâmetros de soldagem recomendados para serras de fitas de $27 \mathrm{~mm}$ de largura.

Tabela 4.6 Parâmetros utilizados nos testes de soldagem de serras de fita bimetálica de $27 \mathrm{~mm}$ de largura.

Tabela 5.1 Análise da Microestrutura na Seção Transversal à Linha Central da Solda.

Tabela 5.2 Perda de material no processo de soldagem topo-a-topo por centelhamento das serras de fita bimetálica de $27 \mathrm{~mm}$.

Tabela 5.3 Análise da Microestrutura na Seção longitudinal à Linha Central da Solda.

Tabela 5.4 Análise da Microestrutura na Ponta dos Dentes da Serra de Fita Bimetálica $27 \mathrm{~mm}$.

Tabela 5.5 Variação da Dureza em Função da Carga de Teste.

Tabela 5.6 Variação da Dureza na LCS em Função da Variação da Corrente Elétrica.

Tabela 5.7 Análise de variância para dureza na LCS dos parâmetros A1, A2 e A3. 
Tabela 5.8 Testes de hipóteses para dureza na LCS dos parâmetros A1, A2 e A3.

Tabela 5.9 Variação da dureza na LCS em função da variação da corrente elétrica.

Tabela 5.10 Variação da Dureza na LCS em Função da Variação da Força de Recalque.

Tabela 5.11 Análise de variância para dureza na LCS dos parâmetros B1, B2 e B3.

Tabela 5.12 Testes de hipóteses para dureza na LCS dos parâmetros B1, B2 e B3.

Tabela 5.13 Variação da Dureza na LCS em Função da Variação da Força de Recalque.

Tabela 5.14 Variação da Dureza na LCS em Função da Variação da Quantidade de Revenidos.

Tabela 5.15 Análise de variância para dureza na LCS dos parâmetros C1, C2 e C3.

Tabela 5.16 Testes de hipóteses para dureza na LCS dos parâmetros C1, C2 e C3.

Tabela 5.17 Variação da Dureza na LCS em Função da Variação da Temperatura de

Tabela 5.18 Análise de variância para dureza na LCS dos parâmetros D1, D2 e D3.

Tabela 5.19 Testes de hipóteses para dureza na LCS dos parâmetros D1, D2 e D3.

Tabela 5.20 Variação da Dureza na LCS em Função da Variação do Tempo de Revenido.

Tabela 5.21 Análise de variância para dureza na LCS dos parâmetros E1, E2 e E3.

Tabela 5.22 Testes de hipóteses para dureza na LCS dos parâmetros E1, E2 e E3.

Tabela 5.23 Relação de durezas das linhas claras x linhas escuras da ZAC.

Tabela 5.24 Análise EDS nas linhas de fluxo da ZAC e MB das amostras A2T2 e A3T2.

Tabela 5.25 Análise EDS na LCS e MB das amostras A2T2 e A3T2.

Tabela 5.26 Verificação de microdureza na austenita retida da amostra D1L1 e D1T1.

Tabela 5.27 Comparação de durezas na ZAC e MB em relação à LCS.

Tabela 5.28 Variação da Dureza na LCS em Função da Variação da Corrente Elétrica -

Tabela 5.29 Análise de variância para dureza na LCS dos parâmetros A1, A2 e A3.Sentido

Tabela 5.30 Testes de hipóteses para dureza na LCS dos parâmetros A1, A2 e A3.

Tabela 5.31 Variação da dureza na LCS em função da variação da corrente elétrica.Sentido

Tabela 5.32 Comparação de dureza na seção transversal e longitudinal à LCS para as 
Tabela 5.33 Dureza média na ponta dos dentes em função de diferentes parâmetros de 152 soldagem.

Tabela 5.34 Resultados dos Ensaios de Torção.

Tabela 5.35 Determinação da relação da área da região dúctil $\mathrm{x}$ área total da fratura.

Tabela 5.36 Resultados dos Ensaios de Tração. 


\section{LISTA DE ABREVIATURAS}

SAE $\quad: \quad$ Sociedade dos Engenheiros de Automóveis (Society of Automotive Engineers).

HSS : : Aço rápido (High Speed Steel).

AISI : $\quad$ Instituto Americano de Ferro e Aço (American Iron and Steel Institute).

HRC : $\quad$ Dureza Rockell - escala C

MO : $\quad$ Microscópio Óptico.

LCS : $\quad$ Linha Central da Solda.

ZAC : $\quad$ Zona afetada pelo calor.

VHN : $\quad$ Número de dureza Vickers (Vickers hardness number).

EN $\quad$ : $\quad$ Norma Européia (European Norm).

EC80 : $\quad$ Classificação do material 16MnCr5 conforme norma EN.

CVN : $\quad$ Energia de impacto no teste Charpy.

AMS : $\quad$ Especificações de Materiais Aeronáuticos (Aerospace Materials Specifications).

HV $\quad$ : $\quad$ Dureza Vickers.

ASTM $\quad: \quad$ Sociedade Americana para Testes de Materiais (American Society for Testing Materials).

AQ $\quad: \quad$ Como temperado (as quenched).

RT : $\quad$ Aço laminado e temperado (rolled and quenched steel).

IIW $\quad$ : $\quad$ Instituto Internacional de Soldagem (International Institute of Welding).

HTLA : $\quad$ Aços de baixa liga tratados termicamente.

LC : $\quad$ Linha de Centro

MB $\quad$ : $\quad$ Metal de Base.

MEV : $\quad$ Microscopia Eletrônico de Varredura.

EDS : $\quad$ Microanálise química por dispersão de energia.

AR : $\quad$ Austenita Retida.

MP : $\quad$ Matéria Prima

LE : $\quad$ Limite de Escoamento.

LR : $\quad$ Limite de Ruptura. 


\section{LISTA DE SÍMBOLOS}

\begin{tabular}{|c|c|c|}
\hline$\% \mathrm{p}$ & : & Porcentagem em peso de um elemento químico na liga em relação a sua fração total. \\
\hline$\%$ at & : & Idem para átomos por cento. \\
\hline $\mathrm{mW}$ & : & MiliWatt \\
\hline Ms & : & Início da transformação martensítica (martensite start). \\
\hline Mf & : & Final da transformação martensítica (martensite finish). \\
\hline $\mathrm{Ae}_{1} \mathrm{e} \mathrm{Ae}_{3}$ & : & Temperaturas de transformações de equilíbrio nos aços. \\
\hline $\mathrm{T}_{\mathrm{p}}$ & : & Temperatura de pico em ${ }^{\circ} \mathrm{C}$ ou $\mathrm{K}$ (peak temperature). \\
\hline$\Delta \mathrm{t}_{8 / 5}$ & : & Tempo de resfriamento de 800 a $500^{\circ} \mathrm{C}(\mathrm{s})$. \\
\hline $\mathrm{C}_{\mathrm{eq}}$ & : & Carbono equivalente. \\
\hline c.d.p. & : & Corpo de prova. \\
\hline$\mu$ & : & Média das amostras. \\
\hline$\sigma$ & $:$ & Desvio padrão das amostras.. \\
\hline $\mathrm{H}_{\mathrm{O}}$ & : & Hipótese a ser testada de que as médias são iguais. \\
\hline $\mathrm{n}$ & : & número de amostras \\
\hline$\alpha$ & : & nível de significância ou grau de incerteza. \\
\hline $\mathrm{F}$ & : & Variável F da distribuição de Snedecor calculada . \\
\hline $\mathrm{F}_{\alpha}$ & : & Variável F da distribuição de Snedecor tabelada. \\
\hline$t_{n-1}$ & $:$ & Variável t da distribuição t de Student calculada para n-1. \\
\hline $\mathrm{t}_{\mathrm{n}-1 ; \mathrm{a} \%}$ & : & Variável t da distribuição $t$ de Student tabelada para n-1 e $\alpha \%$. \\
\hline$d_{\mathrm{A} 1 \mathrm{~A} 2}$ & : & $\begin{array}{l}\text { Diferença dos valores de dureza das amostras do parâmetro A1 em relação ao A2. Idem } \\
\text { para os outros parâmetros B, C, D e E. }\end{array}$ \\
\hline$d_{\mathrm{A} 1 \mathrm{~A} 3}$ & : & $\begin{array}{l}\text { Diferença dos valores de dureza das amostras do parâmetro A1 em relação ao A3. Idem } \\
\text { para os outros parâmetros B, C, D e E. }\end{array}$ \\
\hline$d_{\mathrm{A} 2 \mathrm{~A} 3}$ & : & $\begin{array}{l}\text { Diferença dos valores de dureza das amostras do parâmetro A2 em relação ao A3. Idem } \\
\text { para os outros parâmetros B, C, D e E }\end{array}$ \\
\hline$\Sigma$ & $:$ & Somatório. \\
\hline $\mathrm{sd}^{2}$ & $:$ & Variância da amostra das diferenças. \\
\hline sd & : & Desvio padrão da amostra das diferenças. \\
\hline$\varepsilon$ & $:$ & Módulo de elasticidade. \\
\hline $\mathrm{Li}$ & $:$ & Comprimento inicial. \\
\hline Lf & $:$ & Comprimento final. \\
\hline$\Delta \mathrm{L}$ & : & Alongamento. \\
\hline
\end{tabular}




\section{RESUMO}

O desempenho de serras de fita bimetálica depende principalmente das características da junção de suas extremidades, executada pelo processo de soldagem topo-a-topo por centelhamento. Este é um processo de soldagem por resistência, constituído por um aquecimento elétrico, seguido por um rápido forjamento dos materiais. $\mathrm{O}$ presente trabalho tem como objetivo, estudar a influência da variação da corrente elétrica, força de recalque e tratamento térmico de revenimento nas microestruturas e propriedades mecânicas das juntas soldadas topo-a-topo por centelhamento. Neste estudo, foram utilizadas amostras de serras de fita bimetálica de $27 \mathrm{~mm}$ de largura e $0,9 \mathrm{~mm}$ de espessura. O material é um composto bimetálico constituído por aço rápido M42 para os dentes, soldado a um corpo de aço carbono de baixa liga e alta resistência D-6a. As microestruturas e as propriedades mecânicas das amostras soldadas foram investigadas. Foi observado que os parâmetros de soldagem e o revenimento afetam as propriedades mecânicas. A dureza na seção transversal à linha central da solda apresentou valores levemente superiores à respectiva dureza na seção longitudinal. Amostras não revenidas resultaram em maior resistência à tração, associada ao parâmetro de menor temperatura de revenimento. Ficou evidenciado que o revenimento reduziu a dureza e a resistência à tração de todas as amostras. 


\begin{abstract}
The performance of bimetal band saw blades depends mainly on the features of joining their ends, carried out by flash butt welding process. This is a resistance welding method, which consists of electrical heating followed by a fast material forging. The present work has the objective of studying the influence of changing the electrical current, upset force and tempering heat treatment on the microstructures and mechanical properties of the flash butt welded joints. In this study, samples of bimetal band saw blades having width of $27 \mathrm{~mm}$ and thickness of $0.9 \mathrm{~mm}$ were employed. The material consists of a composite M42 high speed steel for the teeth welded together with a D-6a ultra-high strength carbon low alloy steel for the backer. The microstructure and mechanical properties have been investigated. It is pointed out that welding parameters and tempering affected the mechanical properties. The transversal hardness to the welding center line has shown values slightly higher than the respective longitudinal hardness. Non-tempered samples gave the highest tensile strength with the parameter of lowest tempering temperature. It is also found that the tempering reduces the hardness and the tensile strength of all samples.
\end{abstract}




\section{INTRODUÇ̃̃O.}

Existem no mercado basicamente três tipos de serras de fita: serras de fita de aço carbono, serras de fita bimetálica e serras de fita de metal duro. As serras de fita bimetálica são as mais empregadas e conforme dados estatísticos a nível mundial representam atualmente $70 \%$ do mercado, enquanto que as serras de aço carbono representam $10 \%$ e as de metal duro $20 \%{ }^{(1)}$, conforme ilustrado na figura 1.1 a seguir.

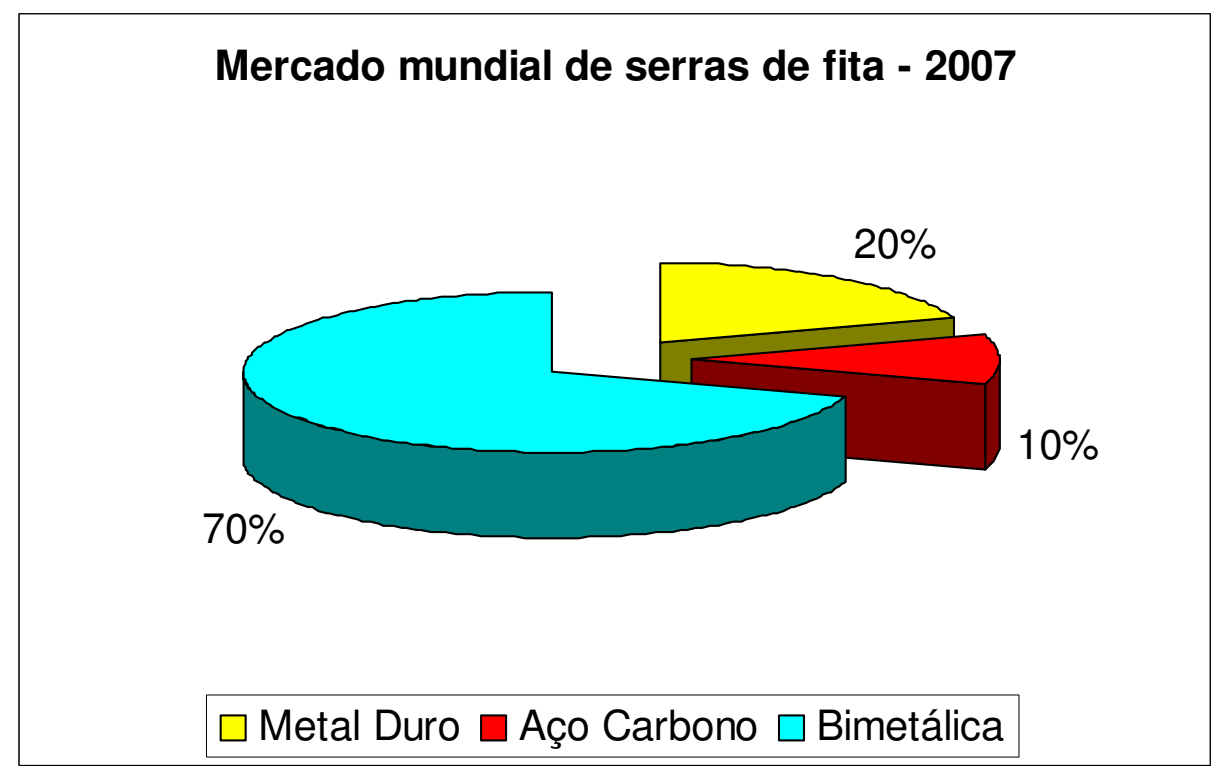

Figura 1.1 Dados do mercado mundial de serras de fita - 2007 .

As serras de fita bimetálica têm sido amplamente utilizadas em vários segmentos industriais, e, devido à sua alta relação custo benefício, tem conquistado cada vez mais aplicações em relação a alternativas para seccionamento de materiais. 
Na maioria das aplicações, como por exemplo, nas empresas do setor metal mecânico e de autopeças, a operação de seccionar materiais constitui a primeira operação do processo de fabricação de um componente, para a qual são especificadas determinadas tolerâncias e características de qualidade, que irão influenciar posteriormente na qualidade de outras operações. Por exemplo, para uma empresa de autopeças que secciona barras laminadas redondas para fabricação de pinos para eixos de comando de válvulas de automóveis, a tolerância para a planicidade da superfície seccionada é de $0,3 \mathrm{~mm}$, para permitir o apoio para operações complementares.

Neste trabalho foi pesquisado o processo de soldagem para emenda topo-a-topo das extremidades da lâmina de serra de fita bimetálica, para a constituição do anel de serra de fita. Esta solda é de extrema importância, uma vez que influencia diretamente a durabilidade da serra de fita e, igualmente, a qualidade e a produtividade das operações de corte dos materiais.

A soldagem de topo por centelhamento é um processo de soldagem por resistência elétrica, que apresenta muitas vantagens, tais como, resistência elevada da solda, preparação simplificada das superfícies a serem soldadas, altas taxas de produção, força de recalque de pequena intensidade, boa concentração de calor e possibilidade de soldar materiais dissimilares. Em uma solda por centelhamento bem executada, as propriedades da solda são muito similares as do metal de base.

Neste trabalho foi dado enfoque especial à linha central da solda, que é a interface onde ocorreu a soldagem topo-a-topo por centelhamento das extremidades da serra de fita bimetálica, pois quando ocorre falha nesta solda, ela normalmente ocorre nesta região. 


\section{REVISÃO BIBLIOGRÁFICA.}

\subsection{SERRAS DE FITA BIMETÁLICA.}

\subsubsection{Histórico.}

A primeira lâmina de serra de fita de aço carbono foi patenteada por William Newberry em Londres, na Inglaterra, em 1808. O processo de junção de suas extremidades era feito através do processo de brasagem, o que resultava em uma solda com pouca flexibilidade e levava a freqüentes quebras da lâmina, quando esta passava pelos volantes da máquina de serrar ${ }^{(1)}$.

As serras de fita bimetálica foram desenvolvidas no final de 1968, quase que simultaneamente pelas empresas americanas DoAll e Simonds International. Devido a este fato, não foi possível patentear as serras de fita bimetálica, pois duas empresas tinham concebido o mesmo produto praticamente ao mesmo tempo $^{(1)}$.

\subsubsection{Aplicações.}

As serras de fita bimetálica têm sido amplamente utilizadas na indústria metal-mecânica, devido à sua excelente relação custo $x$ benefício, em comparação com alternativas para seccionamento de materiais, como por exemplo, serras circulares, processos de oxicorte e cortes a laser, a plasma, a jato de água, etc. 
As serras de fita bimetálica associam alta dureza e alta resistência ao calor e ao desgaste das extremidades cortantes, com excelente tenacidade e resistência à tração de sua parte estrutural, o que permite sua aplicação nos mais variados ramos industriais, como metal mecânico, siderurgia, autopeças, aeronáutica, fabricação de tubos, etc.

As serras de fita bimetálica são aplicadas tanto para o corte de materiais ferrosos quanto nãoferrosos como, por exemplo, aços carbono ligados e não ligados, aços inoxidáveis, cobre, latão, bronze, magnésio, alumínio, inconel e outros materiais, nos formatos maciços e perfilados, conforme exemplificado na figura 2.1 .

Cada aplicação de serra de fita bimetálica requer uma escolha específica, para fins de produtividade e eficiência de corte, o que implica em diferentes geometrias e passos dos dentes das extremidades cortantes, diferentes larguras, espessuras e tipos de materiais empregados.

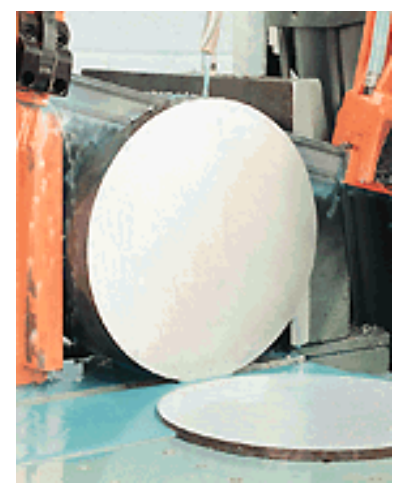

(a)

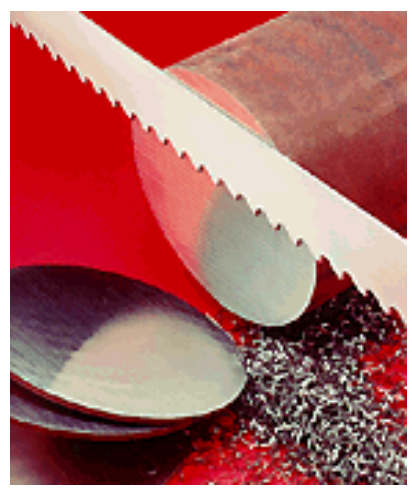

(b)

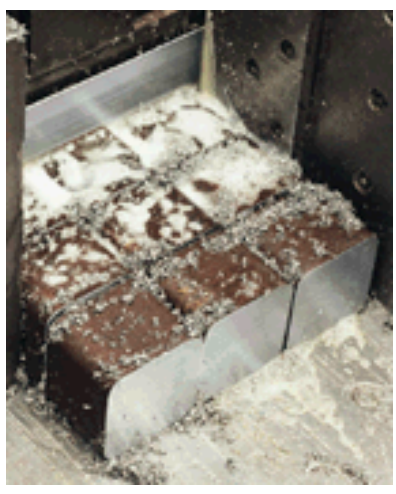

(c)

Figura 2.1 Exemplos de aplicações de serras de fita bimetálica: (a) e (b) aço SAE 52100, diâmetro das barras de 203,2 mm; (c) aço SAE 1018, dimensões dos perfis de 76,2 mm x 76,2 $\mathrm{mm}^{(2)}$ 


\subsubsection{Materiais das Serras de fita bimetálica.}

As serras de fita bimetálica são fabricadas a partir de uma fita bimetálica, constituída por dois materiais dissimilares, cujas principais características serão descritas a seguir.

\subsubsection{Fitas Bimetálicas para Serras de Fita.}

As fitas bimetálicas são constituídas por uma fita estreita de aço rápido (HSS) soldado à extremidade de uma outra fita de aço carbono de baixa liga e alta resistência, denominada corpo. A fita de aço rápido proporciona alta dureza e alta resistência ao calor e ao desgaste, enquanto que o corpo de aço carbono ligado possui elevada resistência à fadiga e à tração ${ }^{(3)}$.

A tabela 2.1 mostra a composição química de alguns materiais típicos utilizados na fabricação de fitas bimetálicas para serras de fita.

O tipo de fita de aço rápido utilizado baseia-se na aplicação especificada para a serra de fita. Serras de fita para cortes de aços estruturais geralmente requerem tenacidade elevada enquanto outras serras para cortes de aços inoxidáveis requererem maior resistência ao calor e ao $\operatorname{desgaste}^{(3)}$ 
Tabela 2.1 Composição química de algumas fitas de aço rápido e de aço carbono empregadas na fabricação de serras de fita bimetálica em $\% \mathrm{p}^{(4)}$.

\begin{tabular}{|c|c|c|c|c|c|c|c|c|}
\hline \multirow{2}{*}{ Elemento } & \multicolumn{5}{|c|}{ Fita de aço rápido } & \multicolumn{2}{c|}{ Fita de aço de baixa liga e médio teor de carbono } \\
\cline { 2 - 9 } & M2* & M3T1** & M42* & Matrix II** & D-6a** & $3 \%$ Cr** & AISI 6150* & AISI 6135* \\
\hline $\mathrm{C}$ & $0,79-0,86$ & $1,00-1,10$ & $1,05-1,10$ & $0,70-0,75$ & $0,45-0,50$ & $0,30-0,35$ & $0,48-0,53$ & $0,30-0,37$ \\
\hline $\mathrm{Mn}$ & $\leq 0,35$ & $0,20-0,35$ & $0,15-0,30$ & $0,15-0,40$ & $0,60-0,90$ & $0,65-0,80$ & $0,70-0,90$ & $0,60-0,90$ \\
\hline $\mathrm{Cr}$ & $3,90-4,40$ & $3,75-4,50$ & $3,50-4,00$ & $3,90-4,40$ & $0,90-1,10$ & $3,00-3,20$ & $0,80-1,10$ & $0,80-1,10$ \\
\hline $\mathrm{Mo}$ & $4,75-5,28$ & $6,00-6,50$ & $9,25-9,75$ & $4,75-5,25$ & $0,90-1,10$ & $2,00-2,20$ & $0,40-0,60$ & $0,15-0,36$ \\
\hline $\mathrm{V}$ & $1,75-2,05$ & $2,40-2,80$ & $1,00-1,30$ & $0,80-1,10$ & $0,08-0,15$ & $0,30-0,40$ & $0,15-0,25$ & $0,15-0,25$ \\
\hline $\mathrm{W}$ & $6,00-6,75$ & $6,00-6,50$ & $1,30-1,70$ & $0,80-1,10$ & - & - & - & - \\
\hline $\mathrm{Co}$ & - & - & $7,75-8,25$ & $7,75-8,25$ & - & - & - & - \\
\hline $\mathrm{Ni}$ & - & - & - & - & $0,50-0,70$ & $0,30-0,90$ & & - \\
\hline $\mathrm{Cu}$ & - & - & - & - & $\leq 0,20$ & - & & - \\
\hline $\mathrm{Al}$ & $0,05-0,10$ & $0,05-0,10$ & $0,03-0,10$ & $0,05-0,10$ & $0,05-0,10$ & $0,40-0,80$ & $0,04-0,10$ & $0,04-0,10$ \\
\hline $\mathrm{Si}$ & $0,15-0,35$ & $0,20-0,35$ & $0,20-0,35$ & $0,15-0,30$ & $0,10-0,25$ & $0,30-0,45$ & $0,20-0,35$ & $0,15-0,30$ \\
\hline $\mathrm{S}$ & $\leq 0,015$ & $\leq 0,010$ & $\leq 0,010$ & $\leq 0,010$ & $<0,007$ & $\leq 0,010$ & $\leq 0,010$ & $\leq 0,010$ \\
\hline $\mathrm{P}$ & $\leq 0,025$ & $\leq 0,025$ & $\leq 0,025$ & $\leq 0,025$ & $\leq 0,015$ & $\leq 0,025$ & $\leq 0,025$ & $\leq 0,025$ \\
\hline
\end{tabular}

* Composições químicas especificadas pelas normas SAE/AISI.

**Marcas comerciais do fabricante Theis Precision Steel Corporation-USA.

A tabela 2.2 mostra a classificação de alguns tipos de fitas de aço rápido para serras de fita bimetálica em relação ao seu desempenho de corte.

Tabela 2.2 Classificação de alguns tipos de fitas de aço rápido usadas em serras de fita bimetálica em função de seu desempenho. O número 1 indica o melhor desempenho ${ }^{(3)}$.

\begin{tabular}{|c|c|c|c|}
\hline PROPRIEDADE & M2 & MATRIX II $^{\circledR}$ & M42 \\
\hline Resistência ao Desgaste & 2 & 3 & 1 \\
\hline Tenacidade & 2 & 1 & 3 \\
\hline Resistência ao Calor & 3 & 2 & 1 \\
\hline
\end{tabular}




\subsubsection{Processo de Fabricação das Fitas Bimetálicas.}

As fitas bimetálicas são constituídas por uma fita de aço rápido, soldada longitudinalmente à extremidade de uma fita de aço carbono de baixa liga e alta resistência. Esta junção é realizada através do processo de soldagem por feixe de elétrons a vácuo, conforme indicado na figura 2.2, e posteriormente, o material bimetálico soldado é enrolado em bobinas. As bobinas de fitas bimetálicas são revenidas, para alívio de tensões e obtenção de durezas e microestruturas especificadas para a região da solda. Posteriormente as bobinas são laminadas ou retificadas, para remoção do excesso de solda, resultando numa espessura da área soldada igual à espessura da fita bimetálica. Finalmente, as bobinas de fitas bimetálicas são endireitadas, para eliminação das curvaturas e deformações inerentes ao processo de soldagem ${ }^{(3)}$.

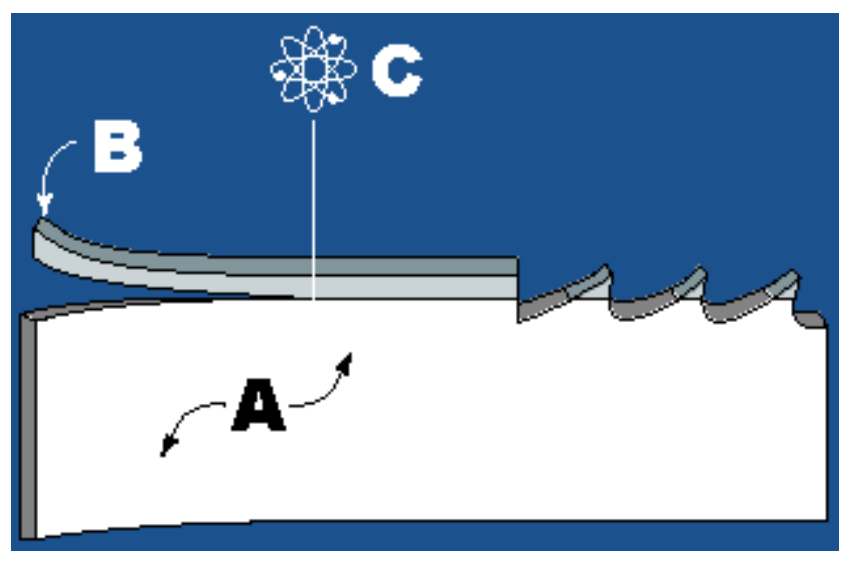

Figura 2.2 Diagrama esquemático mostrando os componentes das fitas bimetálicas e seu respectivo processo de fabricação: A - corpo da fita em aço carbono de baixa liga e alta resistência; $\mathrm{B}$ - fita de aço rápido; $\mathrm{C}$ - solda por feixe de elétrons ${ }^{(5)}$. 


\subsubsection{Processo de Fabricação das Serras de fita bimetálica.}

As serras de fita bimetálica são fabricadas a partir de bobinas de fitas bimetálicas, onde primeiramente é feito o fresamento dos dentes através da extremidade da fita composta pelo aço rápido. Posteriormente, os dentes são travados, ou seja, levemente dobrados para a direita e para a esquerda sucessivamente, para proporcionar a folga necessária à passagem do corpo da serra de fita durante a operação de corte. Na próxima etapa, as bobinas são temperadas e revenidas em temperaturas específicas, de forma que os dois materiais dissimilares da fita bimetálica possam responder adequadamente e simultaneamente ao tratamento térmico, conforme as características de cada material. Após o tratamento térmico, é efetuado o jateamento do corpo da serra de fita, para remoção das fuligens e carepas provenientes do tratamento térmico, a gravação dos dados de identificação da serra de fita e a aplicação de óleo para proteção superficial, após o qual as serras de fitas são novamente enroladas em bobinas e disponibilizadas para os centros de soldagens.

\subsubsection{Tratamento Térmico de Têmpera e Revenimento das Serras de Fita Bimetálicas.}

Após os processos de fresamento e travamento dos dentes, as bobinas são temperadas e revenidas para proporcionar as respectivas microestruturas, durezas e propriedades para os dentes e para o corpo das serras de fita bimetálica simultaneamente, conforme especificações de projeto.

No processo de têmpera e revenimento das serras de fita bimetálica deve ser obtida uma microestrutura constituída por carbonetos globulares e uniformemente distribuídos em matriz martensítica revenida, isenta de austenita retida e de descarbonetação para os dentes de aço rápido, conforme mostrado na figura 2.3. A ausência de ferrita livre indica a inexistência de 
descarbonetação. A dureza medida na ponta dos dentes após a têmpera e revenimento deve situarse na faixa de 66-69 $\mathrm{HRC}^{(3,6-8)}$.

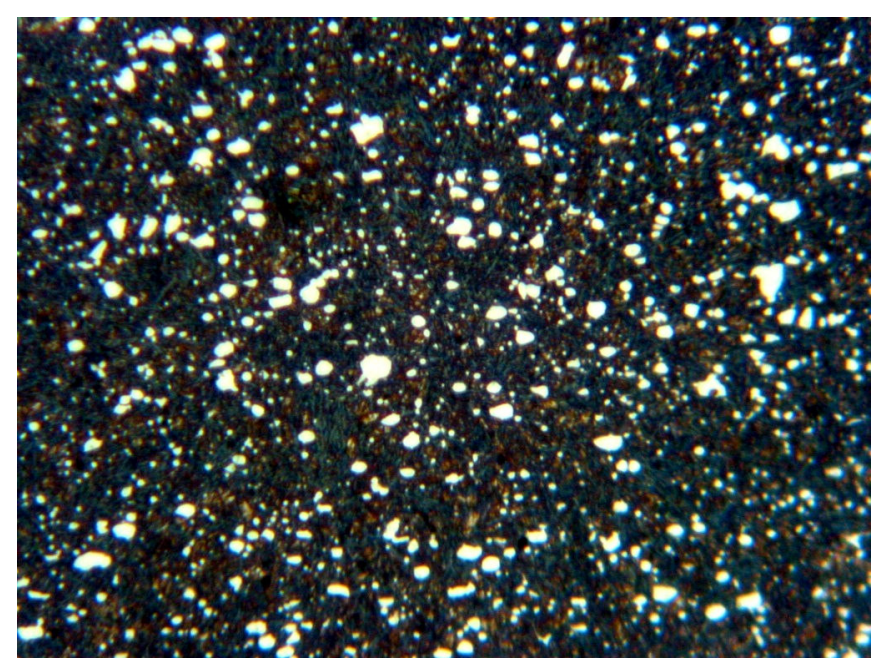

Figura 2.3 Microestrutura da ponta de um dente de serra de fita $27 \mathrm{~mm}$ - 3/4 em aço rápido M42, mostrando carbonetos uniformes e bem distribuídos em matriz martensítica revenida fina, isenta de austenita retida e de descarbonetação(7) ${ }^{(70}$. Aumento:1.000 X.

Analogamente, o corpo da serra de fita de aço carbono de baixa liga e alta resistência deve apresentar uma microestrutura predominante de martensita revenida fina, isenta de carbonetos e de austenita retida, conforme mostrado na figura 2.4. A respectiva dureza medida após têmpera e revenimento deve situar-se na faixa de 44-49 $\mathrm{HRC}^{(3,6-8)}$. 


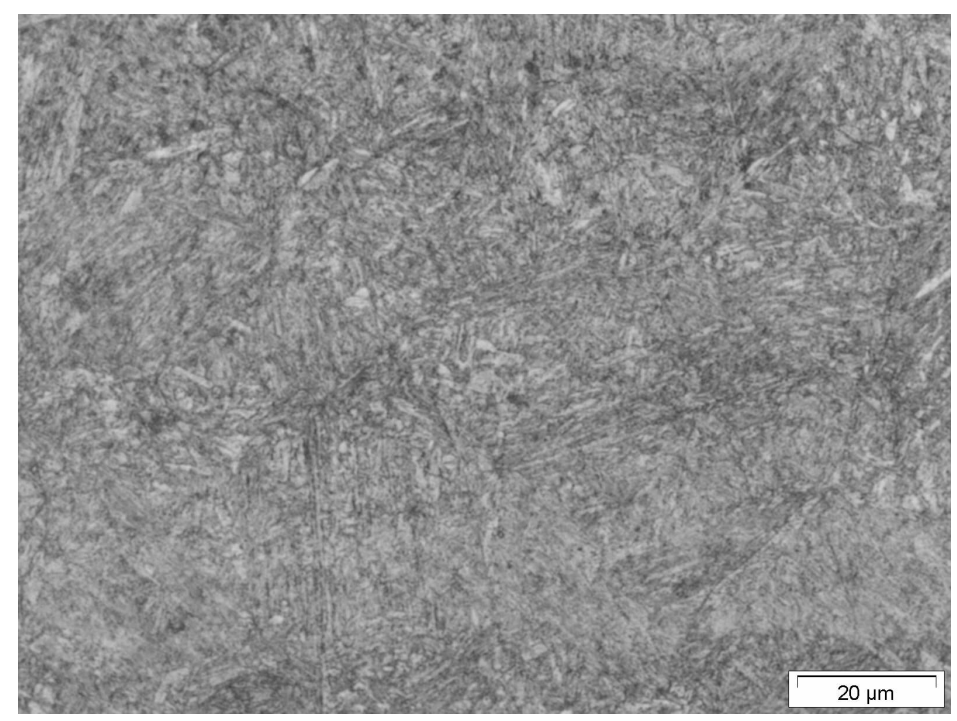

Figura 2.4 Microestrutura do corpo de uma serra de fita $27 \mathrm{~mm}$ - 4/6 em aço carbono de alta resistência e baixa liga D-6a, mostrando martensita revenida fina. MO. Aumento: 500 X.

O revenimento é feito para melhorar as propriedades mecânicas da microestrutura martensítica resultante do tratamento térmico, ou seja, transformar as microestruturas martensíticas temperadas, tanto dos dentes como do corpo, em martensita revenida e isenta de austenita retida, reduzindo-se desta forma a dureza e a fragilidade resultantes da têmpera em altas temperaturas e conseqüentemente aumentando-se a tenacidade destes materiais ${ }^{(6-8)}$.

\subsubsection{Processo de Soldagem das Serras de fita bimetálica.}

As bobinas de serras de fita bimetálica são cortadas em segmentos, cujos comprimentos são definidos conforme os diferentes tipos de máquinas de serrar existentes no mercado, e suas extremidades são unidas pelo processo de soldagem topo-a-topo por centelhamento, para a formação de uma cinta de lâmina de serra de fita bimetálica. 
As soldas das extremidades das serras de fita são executadas no corpo da fita bimetálica, ou seja, na parte inferior da garganta dos dentes, que fica no centro do passo dos dentes e abaixo do componente de aço rápido. Desta forma, as faces dos dentes de aço rápido não são soldadas, porém, os dentes próximos da região da solda, que se situam na zona afetada pelo calor (ZAC), sofrem o efeito das altas temperaturas do processo de soldagem, conforme ilustrado pela figura 2.5 .

As altas temperaturas produzidas no processo de soldagem transformam as microestruturas e as propriedades dos materiais das serras de fita bimetálica na linha central da solda (LCS) e na ZAC, aumentando excessivamente a dureza e reduzindo significativamente a ductilidade e a tenacidade dos materiais da junta soldada. Portanto, após o processo de soldagem, deve ser aplicado um tratamento térmico de revenimento compatível com os materiais das serras de fita bimetálica, com o objetivo de reduzir a dureza e as tensões internas e conceder flexibilidade ao material $\operatorname{soldado}^{(9)}$.

Devido ao processo de soldagem topo-a-topo por centelhamento empregado, forma-se um excesso de material nas faces da área da junção da serra de fita similar a uma rebarba. Este material é removido por esmerilhamento ou lixamento, através de dispositivos específicos, e deve resultar em uma espessura da área soldada igual à espessura da serra de fita. Esta operação requer cuidados em sua execução, para não causar variações na espessura da fita, não deixar riscos ou marcas de ferramenta na superfície acabada e nem gerar superaquecimento na microestrutura da área soldada. 


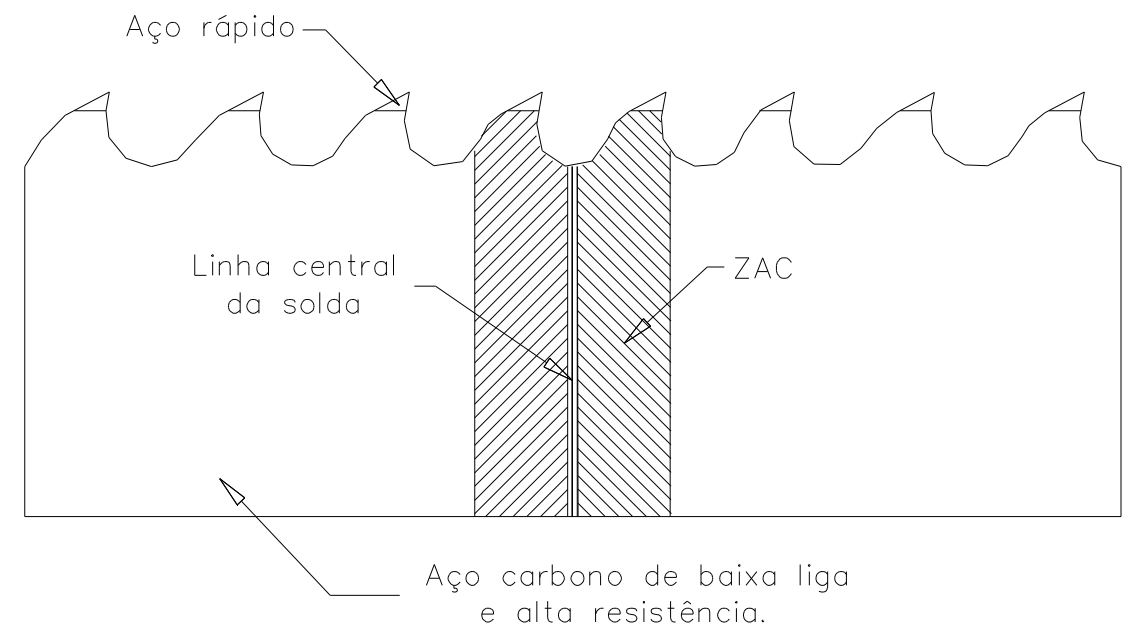

Figura 2.5 Diagrama esquemático mostrando a posição da solda topo-a-topo por centelhamento da serra de fita.

\subsection{PROCESSO DE SOLDAGEM POR RESISTÊNCIA.}

\subsubsection{Princípio de Funcionamento.}

O processo de soldagem por resistência consiste na junção de duas peças através da geração de calor, devido à resistência do conjunto à passagem de uma alta corrente elétrica e da aplicação de uma determinada pressão nas superfícies a serem unidas, por meio de eletrodos não consumíveis. Durante o processo, as peças são aquecidas pelo efeito Joule e ocorre a fusão localizada na região de contato entre ambas ${ }^{(10-15)}$.

A energia térmica total gerada durante o processo de soldagem pode ser calculada pela lei de Joule $^{(10)}$, conforme a equação [ 1 ]. 


$$
Q=\frac{1}{J} \int_{0}^{t} I^{2} R_{T} d t
$$

Onde:

$\mathrm{Q}=$ Energia térmica total $(\mathrm{J})$

$\mathrm{J}=1 / 4,185 \mathrm{cal}$

$\mathrm{I}=$ Corrente de soldagem $(\mathrm{A})$

$\mathrm{R}_{\mathrm{T}}=$ Resistência elétrica total do conjunto ou resistência entre eletrodos $(\Omega)$

$\mathrm{dt}=$ Intervalo de tempo de passagem da corrente $(\mathrm{s})$.

A resistência total do conjunto, ou resistência entre eletrodos, é a somatória de todas as resistências à circulação de corrente elétrica entre os eletrodos conectados ao secundário de um transformador, ou seja, é um conjunto de cinco resistências elétricas, conforme ilustrado na figura $2.6^{(10)}$.

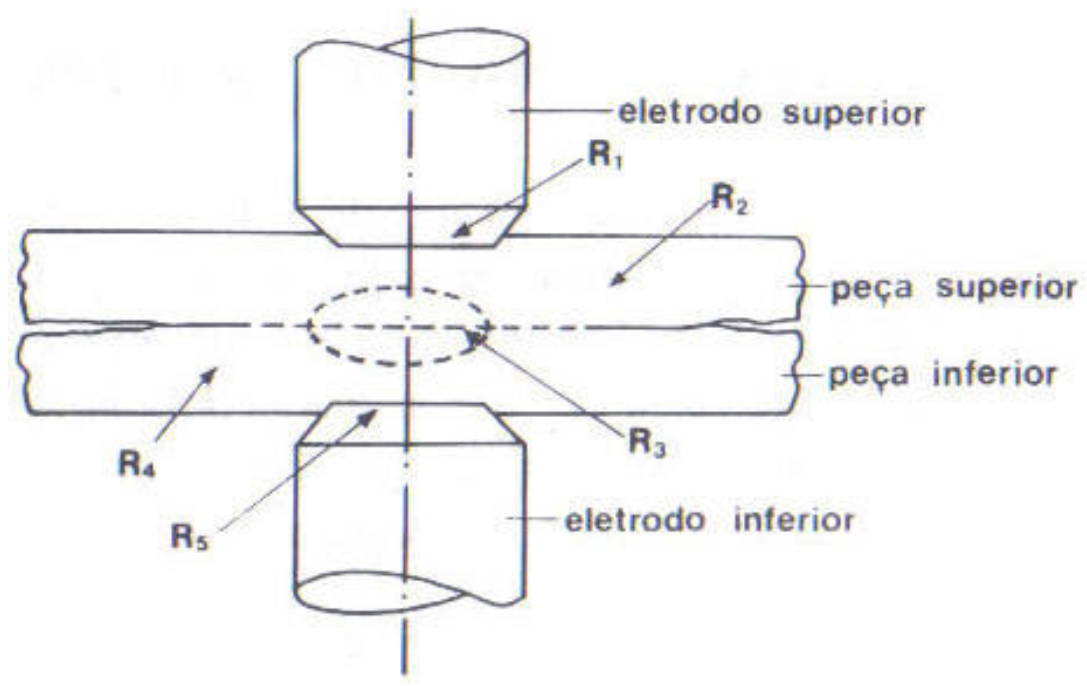

Figura 2.6 Esquema mostrando as resistências dos componentes no processo de soldagem por resistência elétrica a ponto ${ }^{(10)}$. 
Observa-se na figura 2.6, que a ligação entre as peças, indicada pelos pontos tracejados, é o resultado de uma fusão localizada, cujo aquecimento é gerado pelo efeito Joule. Por simplicidade, foi utilizada a soldagem a ponto para ilustrar o processo de junção na soldagem por resistência elétrica $^{(10)}$.

A resistência total do conjunto, ou resistência entre eletrodos, é dada pela soma das resistências parciais, conforme equação [ 2$]^{(10)}$ :

$$
R_{T}=R_{1}+R_{2}+R_{3}+R_{4}+R_{5}
$$

Onde:

$\mathrm{R}_{\mathrm{T}}=$ Resistência elétrica total do conjunto ou resistência entre eletrodos $(\Omega)$

$\mathrm{R}_{1}=$ Resistência de contato entre eletrodo superior e peça superior $(\Omega)$.

$\mathrm{R}_{2}=$ Resistência da peça superior $(\Omega)$.

$R_{3}=$ Resistência de contato entre as peças superior e inferior $(\Omega)$.

$\mathrm{R}_{4}=$ Resistência da peça inferior $(\Omega)$.

$\mathrm{R}_{5}=$ Resistência de contato entre eletrodo inferior e peça inferior $(\Omega)$.

De todas as resistências, $\mathrm{R}_{3}$ é a mais importante, porque é nesse local que se formará a geração de calor para ocorrer a fusão localizada. As resistências $R_{1}$ e $R_{5}$ tornam-se também importantes no caso de metais com baixa resistividade elétrica. As resistências $R_{2}$ e $R_{4}$ não têm praticamente influência nos estágios iniciais de soldagem; são importantes, porém, nos estágios finais, pois os 
materiais já estarão aquecidos, e quanto maior a temperatura do material a ser soldado, maior será sua resistência elétrica ${ }^{(10,13,16)}$.

Resumindo, as resistências de contato têm papel muito mais importante na geração de calor, durante o processo de soldagem por resistência, do que as resistências das peças a serem $\operatorname{soldadas}^{(10)}$.

\subsubsection{Resistência Elétrica de Contato.}

Os altos valores das resistências nas superfícies de contato são causados pela existência de um filme de óxido não condutor, além de gorduras, poeiras, etc, existentes nas irregularidades superficiais das peças, que são da ordem de 200 camadas atômicas ou 500 Ângstrons. Esta alta resistência inicial de contato é reduzida pela ruptura do dielétrico entre os pontos de contato, através da utilização de pressão associada a uma corrente elétrica de alta intensidade (acima de 1.000 A). Os valores das resistências de contato resultam em potências dissipadas de calor, que para materiais ferrosos estão no intervalo de 50-100 mW; no caso do alumínio, este valor cai para $20 \mathrm{~mW}^{(10,12)}$.

Quanto maior for a resistência elétrica de um material, maior será seu aquecimento devido à passagem da corrente elétrica de soldagem, que é concentrada em uma determinada área. Os aços possuem uma grande resistência à passagem da corrente elétrica e, desta forma, pertencem ao grupo de materiais que proporciona as melhores características de soldabilidade ${ }^{(16)}$. 
Estudos teóricos, complementados com fatores de correção experimentais, indicam para a resistência de contato o valor dado pela equação [ 3 ], válida no intervalo de pressão de contato dos eletrodos: $0,8 \mathrm{Y}>\mathrm{P} \geq 0,3 \mathrm{Y}^{(10)}$.

$$
R=\frac{0,85 \rho \sqrt{\mathrm{Y}}}{\sqrt{\pi n C_{p}}}
$$

Onde:

$\mathrm{P}=$ Pressão de fixação dos eletrodos $\left(\mathrm{N} / \mathrm{m}^{2}\right)$.

$\mathrm{Y}=$ Limite de escoamento $\left(\mathrm{kgf} / \mathrm{cm}^{2}\right)$.

$\mathrm{R}=$ Resistência de contato $(\mu \Omega)$.

$\rho=$ Resistividade elétrica dos materiais em contato $(\Omega \mathrm{m})$.

$\mathrm{n}$ = Número de pontos por unidade de área.

$\mathrm{C}_{\mathrm{p}}=$ Porcentagem da área metálica condutora em contato; característica do estado superficial das peças em contato.

Outro aspecto a ser ressaltado é a variação da resistência de contato com a temperatura, dada pela equação [ 4$]^{(10)}$ :

$$
R=K_{1} e^{-K_{2}(T-30)}+K_{3}
$$

Onde:

$\mathrm{R}=$ Resistência de contato $(\mu \Omega)$.

$\mathrm{K}_{\mathrm{i}}=$ Constantes para cada material. 
$\mathrm{e}=$ base dos logaritmos neperianos 2,718

$\mathrm{T}=$ Temperatura $\left({ }^{\circ} \mathrm{C}\right)$.

\subsubsection{Tipos de Soldagem por Resistência.}

O processo de soldagem por resistência pode ser dividido em dois grandes grupos ${ }^{(11,14)}$ :

- Soldagem por superposição.

- Soldagem topo-a-topo.

A soldagem por superposição pode ser subdividida em três processos ${ }^{(10-14)}$ :

- Soldagem a ponto: muito utilizada na indústria automobilística, para soldas de carrocerias de veículos, etc.

- Soldagem por projeção: é muito similar à solda a ponto, onde mais de um ponto de solda pode ser formado de cada vez, aumentando-se a produtividade.

- Soldagem por costura: usada para fabricação de tubos com costura, etc.

Analogamente, a soldagem topo-a-topo pode ser subdividida em três processos ${ }^{(10-14)}$ :

- Soldagem topo-a-topo por centelhamento: usada para soldagem de serras de fitas, trilhos, correntes, aros de rodas de carros e caminhões, etc. 
- Soldagem por recalque: usada em laminações para soldagem de produtos feitos a partir de arames, etc.

- Soldagem por percussão (alta freqüência): usada na indústria eletrônica para unir componentes em superfícies planas, etc.

Dos processos citados, o enfoque será dado no processo de soldagem topo-a-topo por centelhamento, que é empregado na fabricação de serras de fita bimetálica.

\subsection{PROCESSO DE SOLDAGEM TOPO-A-TOPO POR CENTELHAMENTO.}

\subsubsection{Histórico.}

O reconhecimento da soldagem topo-a-topo por centelhamento, ou simplesmente soldagem por centelhamento, como um processo de soldagem ocorreu em 1889 nos Estados Unidos, com a publicação da patente de Charles Coffin ${ }^{(17)}$.

Apesar da soldagem topo-a-topo por centelhamento ter sido provavelmente praticada anteriormente àquela data, usando-se máquinas de soldagem topo-a-topo por resistência operadas manualmente, o primeiro relato de aplicação comercial deste processo data de $1913^{(17)}$.

Durante a primeira guerra mundial, aumentou-se a aplicação da soldagem por centelhamento para a produção de juntas de topo, e a maior taxa de expansão deste processo ocorreu durante a segunda guerra mundial. Desde então, este processo tem sido amplamente utilizado para a rápida 
produção de juntas de topo de alta qualidade, em uma grande variedade de materiais e aplicações $^{(17)}$.

\subsubsection{Princípios do Processo de Soldagem topo-a-topo por centelhamento.}

Duas partes a serem soldadas são fixadas através de mordentes-eletrodos, que são conectados ao secundário de um transformador de soldagem por resistência, de forma que suas extremidades estejam em contato. No momento que o ciclo de soldagem é iniciado, o mordente móvel afasta-se aproximadamente $0,2 \mathrm{~mm}$ e a tensão elétrica é aplicada, enquanto uma parte avança lentamente na direção da outra. Quando ocorre o contato nas irregularidades superficiais, estabelece-se um fluxo de corrente, que gera pequenas descargas elétricas através de curtos circuitos, que fazem com que as áreas das interfaces sofram um aquecimento resistivo. A corrente elétrica do secundário do transformador provoca um aquecimento pelo efeito Joule dos pontos de contato, até que o ponto de fusão do material seja alcançado. $\mathrm{O}$ volume de material fundido, que se aproxima de uma forma esférica, devido aos efeitos da tensão superficial, é então expelido violentamente para fora da região da solda através de forças magnéticas criadas pelo fluxo de corrente, com a conseqüente formação de pequenas partes incandescentes de material sob formas de faíscas e centelhas, conforme ilustrado pela figura 2.7. Esta ação é chamada de centelhamento $^{(9,12,14-15,17-23)}$.

Conforme as partes vão sendo aproximadas, o centelhamento continua até que as superfícies adjacentes apresentem uma porção de metal fundido e uma pequena extensão longitudinal de cada parte, posterior à sua interface, atinja a temperatura de forjamento de forma uniforme. A solda é então formada pela aplicação de uma força de compressão, denominada recalque, que faz 
com que as superfícies adjacentes fundidas tenham um amplo contato, expulsando-se o metal fundido para fora da interface e forjando as peças simultaneamente, conforme ilustrado pela figura 2.7. A tensão que causa o centelhamento é desligada no início da aplicação da força de recalque ${ }^{(9,12,14-15,17-23)}$.

Durante a etapa de recalque, as superfícies metálicas opostas atingem um determinado contato, no qual ligações interatômicas se estabelecem através da área interfacial total. A natureza destas ligações é tal que, ocorre o coalescimento das duas superfícies e a resistência mecânica da junta fica comparável com àquela do metal de base ${ }^{(17)}$. A figura 2.7 ilustra as etapas básicas do processo de soldagem topo-a-topo por centelhamento.

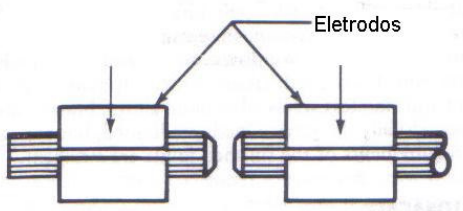

(A)
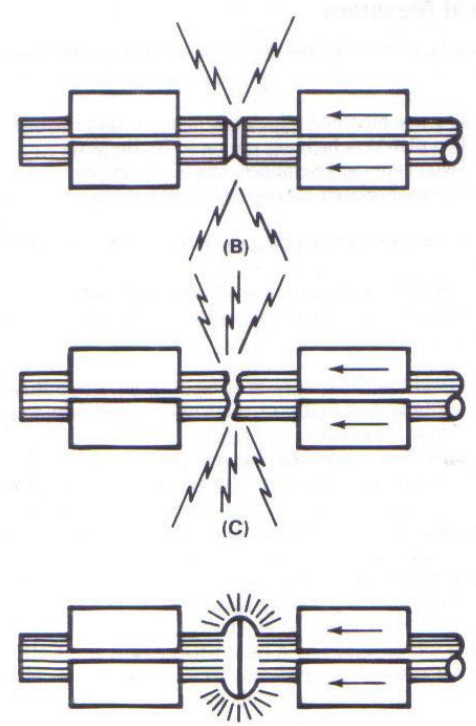

(D)

Figura 2.7 Etapas básicas na soldagem topo-a-topo por centelhamento: (A) posicionamento e fixação das peças; (B) aplicação da tensão de centelhamento e início do deslocamento da portaeletrodo móvel; (C) centelhamento; (D) Desligamento da corrente e aplicação da força de recalque $^{(18)}$. 


\subsubsection{Estágios do processo de soldagem topo-a-topo por centelhamento.}

Basicamente o processo de soldagem topo-a-topo por centelhamento é dividido em três estágios: pré-aquecimento, centelhamento e recalque. O pré-aquecimento é utilizado somente em casos onde se faz necessário o aquecimento dos materiais previamente à soldagem, para redução de tensões residuais e eliminação de trincas no resfriamento pós-soldagem. Esta operação consiste em movimentos oscilatórios das extremidades das peças a serem soldadas, aproximando-se, para aquecimento da junta através da circulação da corrente elétrica, e afastando-se a seguir. Este ciclo é repetido até que as extremidades das peças estejam aquecidas e aptas a iniciarem o centelhamento, a partir do qual as extremidades são avançadas uma contra a outra de forma lenta e $\operatorname{gradual}^{(24-26)}$.

Após o centelhamento, o processo é completado com rápido recalque das extremidades adjacentes. Quando o pré-aquecimento não é utilizado, o processo de soldagem se resume a somente dois estágios, conforme mostra a figura 2.8. O revenimento não é considerado como parte do processo de soldagem ${ }^{(18)}$.

O estágio de recalque proporciona ainda a redução e/ou eliminação das porosidades geradas durante a ação de centelhamento e também a remoção dos óxidos gerados através do processo de aquecimento durante a fase de centelhamento ${ }^{(18)}$. 


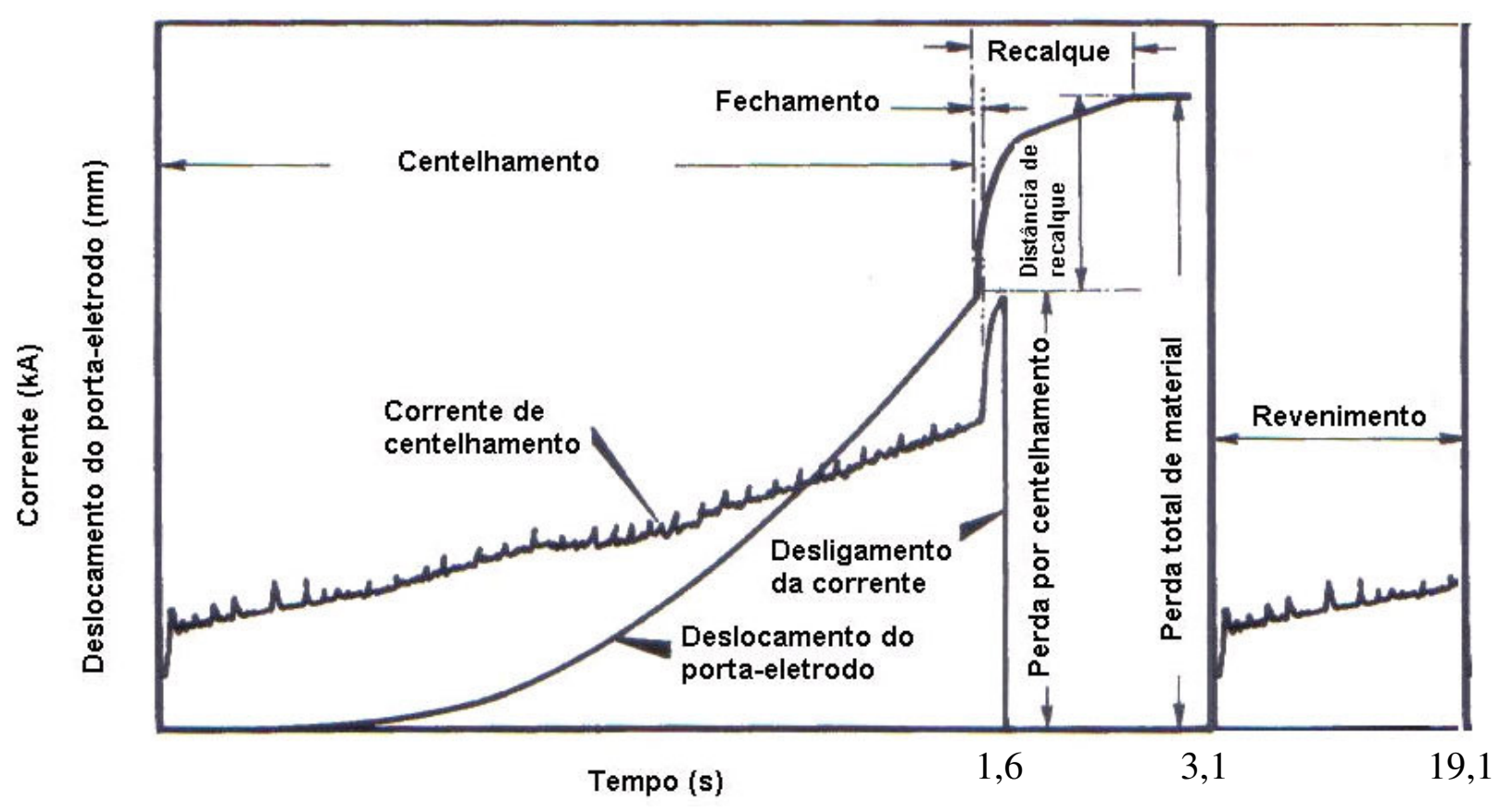

Figura 2.8 Diagrama esquemático de um ciclo de soldagem por centelhamento ${ }^{(17)}$.

\subsubsection{Equipamento típico de soldagem topo-a-topo por centelhamento.}

Um equipamento típico de soldagem topo-a-topo por centelhamento consiste das seguintes partes principais ${ }^{(17-18,22)}$ :

- Estrutura da máquina, na qual está montada o porta-eletrodo fixo e um conjunto de guias isoladas eletricamente.

- Porta-eletrodo móvel, montado sobre as guias isoladas eletricamente.

- Conjunto de mordentes-eletrodos, montados rigidamente em cada porta-eletrodo, para alinhar e fixar as partes a serem soldadas.

- Mecanismo para controlar o deslocamento do porta-eletrodo móvel.

- Transformador de energia de soldagem. 
A figura 2.9 ilustra os principais componentes de um equipamento para soldagem topo-a-topo por centelhamento.

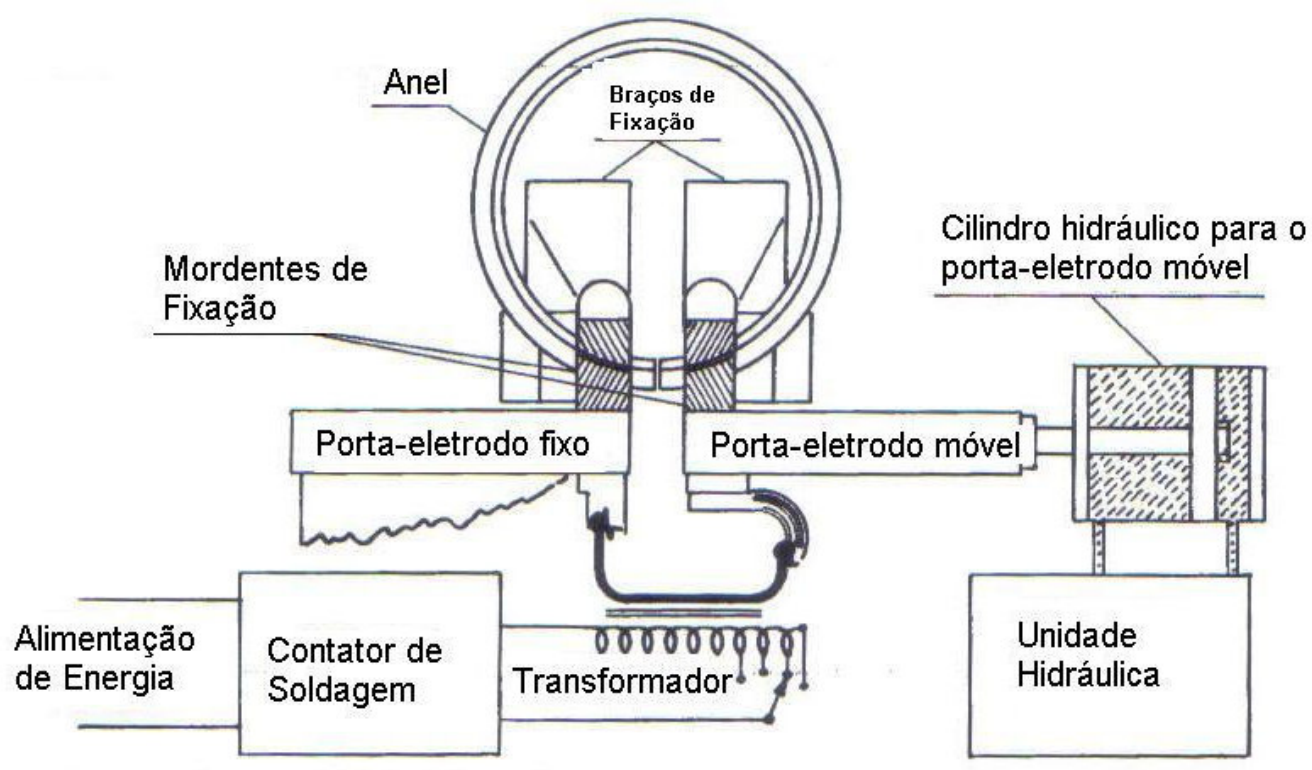

Figura 2.9 Diagrama esquemático de um equipamento de soldagem topo-a-topo por centelhamento $^{(17)}$.

\subsubsection{Descrição do Processo de Soldagem Topo-a-Topo por Centelhamento para Serras de}

Fita.

As extremidades da serra de fita são alinhadas, justapostas e fixadas no equipamento de soldagem através dos mordentes-eletrodos. As seguintes operações são realizadas e controladas por um mecanismo excêntrico, quando o ciclo de soldagem é iniciado ${ }^{(9,23)}$ :

- As extremidades da serra de fita são afastadas aproximadamente 0,2 mm, através do recuo do mordente-eletrodo móvel, enquanto a energia elétrica é aplicada. 
- O mordente-eletrodo móvel é avançado na direção do mordente-eletrodo fixo e o centelhamento é iniciado, através de curtos circuitos nas superfícies de contato do material.

- O mordente-eletrodo móvel continua avançando-se, originando-se curtos circuitos constantes e a expulsão de partículas incandescentes sob a forma de centelhas.

- Durante o processo de centelhamento as extremidades da serra de fita são aquecidas até aproximadamente $1.000^{\circ} \mathrm{C}$, quando a energia elétrica é desligada.

- As extremidades da serra de fita aquecidas são comprimidas por uma força de recalque, através de um avanço rápido do mordente-eletrodo móvel, até que a temperatura do material tenha decrescido e a pressão de recalque não seja mais suficiente para avançar o mordente-eletrodo.

- O processo de soldagem (centelhamento e recalque) é finalizado e os mordentes de fixação são abertos e retornam-se para sua posição inicial.

O revenimento, da solda é realizado no próprio equipamento de soldagem, logo após o término do processo de recalque.

\subsubsection{Influência das Variáveis do Processo de Soldagem topo-a-topo por centelhamento.}

A qualidade de uma junta de topo soldada por centelhamento requer a combinação e ajustes adequados de diversas variáveis do processo. As variáveis do processo de soldagem topo-a-topo por centelhamento são divididas basicamente em duas classes ${ }^{(17)}$ : 
- Variáveis de centelhamento.

- Variáveis de recalque.

\subsubsection{Variáveis de Centelhamento.}

As variáveis de centelhamento controlam a distribuição de temperatura que existe nas interfaces adjacentes da junta de topo no instante do recalque. Aproximadamente a mesma distribuição de temperatura pode ser obtida com diferentes combinações das variáveis de centelhamento, sendo que a melhor combinação é aquela que proporciona uma distribuição de temperatura uniforme nas interfaces da junta, em um tempo mínimo, e com a menor perda de material durante o centelhamento. As principais variáveis de centelhamento são relacionadas a seguir ${ }^{(19)}$ :

\section{a) Modelo de Centelhamento}

Para se produzir uma junta soldada com boa resistência, a distribuição de temperatura através da junta deve ser uniforme ${ }^{(18,27)}$.

Nippes, Savage, Suzuki e Chang ${ }^{(28)}$ demonstraram através de análises matemáticas baseadas em medições de temperaturas experimentais que, sob condições apropriadas, uma distribuição uniforme de temperatura é obtida quando a temperatura média das interfaces de centelhamento atinge a temperatura de fusão do material.

Variações na forma de obtenção do centelhamento, como centelhamento linear (velocidade constante do porta-eletrodo), centelhamento parabólico (taxa constante de aceleração do portaeletrodo) e centelhamento cúbico (taxa constante de aumento da aceleração do porta-eletrodo 
com o tempo), alteram a obtenção do gradiente de temperatura na interface da junta, bem como na quantidade de material perdido ${ }^{(19,28)}$ :

Do ponto de vista prático, vários modelos de centelhamento têm sido relatados na literatura para máquinas automáticas de soldagem topo-a-topo por centelhamento. Na maioria dos casos, os modelos de centelhamento mais utilizados são caracterizados por um período de aproximação à velocidade lenta e constante no início, para facilitar o início da operação de centelhamento com peças de trabalho frias. Este centelhamento lento e linear transforma-se em um modelo de centelhamento por aceleração, que muito se aproxima do centelhamento parabólico em uma grande parte do intervalo total de centelhamento ${ }^{(19)}$.

Em geral, quanto mais alta for a taxa de aceleração do porta-eletrodo (ou maior for a velocidade do porta-eletrodo para centelhamento linear), mais acentuado será o gradiente de temperatura produzido. Os gradientes de temperatura produzidos com centelhamento parabólico são mais íngremes do que aqueles para centelhamento linear, considerando-se a mesma perda de material resultante do mesmo tempo de centelhamento ${ }^{(19)}$.

Em consequiência disto, a forma da curva de distribuição de temperatura em um material em particular pode ser controlada através da escolha apropriada do modelo de centelhamento. Como a resistência ao escoamento na compressão, ou a resistência ao fluxo, é um fenômeno sensível à temperatura, o comportamento do material durante a etapa de recalque do ciclo de soldagem é notadamente dependente do modelo de centelhamento. Portanto, a escolha do modelo de centelhamento é extremamente importante na produção de uma solda por centelhamento de qualidade $^{(19)}$. 


\section{b) Distância Inicial de Fixação.}

A distribuição de temperatura também é influenciada pela extensão da zona onde há transmissão de calor entre a interface de centelhamento e os mordentes de fixação (eletrodos) resfriados a água. A distância inicial de fixação, e até certo ponto a espessura das peças a serem soldadas, determinam a extensão do fluxo de calor. Em geral, quanto maior for a distância inicial de fixação, mais uniforme será o gradiente de temperatura, sujeito às seguintes restrições ${ }^{(19)}$ :

- A difusividade térmica do material limita a extensão da zona onde há transmissão de calor em um determinado comprimento, a partir do qual nenhum efeito é notado na distribuição uniforme de temperatura em termos práticos.

- Quanto maior for a difusividade térmica, maior será a extensão da zona onde há transmissão de calor em um determinado comprimento. Portanto, a distribuição de temperatura em materiais com elevada difusividade térmica, tais como ligas de alumínio e cobre, é mais sensível à distância de fixação, em relação aos materiais com baixa difusividade térmica, tais como aços inoxidáveis e super ligas.

\section{c) Perda de Material por Centelhamento}

O valor ideal para perda de material por centelhamento é o valor mínimo necessário para estabelecer a distribuição estável de temperatura desejada. Do ponto de vista prático, é preferível 
aumentar um pouco esta perda de material acima do valor mínimo, para garantir o alcance da distribuição estável de temperatura ${ }^{(19)}$.

A quantidade de material que se perde no centelhamento para produzir uma distribuição estável de temperatura depende da difusividade térmica e do modelo de centelhamento ${ }^{(19,28)}$.

\section{d) Tensão de Centelhamento.}

A tensão de centelhamento é determinada pelo ajuste da chave seletora do transformador e deve ser ajustada para o valor mais baixo possível, de forma a proporcionar um bom e consistente processo de centelhamento ${ }^{(19-22)}$.

O uso de controladores eletrônicos de fase não é um recurso eficiente para reduzir a tensão de centelhamento. A forma de onda da tensão do secundário produzida através deste meio não é compatível com uma boa ação de centelhamento ${ }^{(19-22)}$.

Centelhamentos proporcionando superfícies mais lisas são obtidas com tensões mais baixas, somente se a forma de onda da tensão é a mais próxima possível de uma forma de onda completamente senoidal $^{(22)}$.

As pesquisas confirmaram as observações práticas de longos tempos, de que a tensão de centelhamento deve ser selecionada como sendo a menor possível, normalmente situada entre 2 e $16 \mathrm{~V}$, suficiente apenas para manter o processo de centelhamento. A faixa de tensão de centelhamento de 2 a $16 \mathrm{~V}$ está bem abaixo da diferença de potencial necessário para iniciar um arco elétrico entre as interfaces de centelhamento. Portanto, o fluxo de corrente durante o 
centelhamento somente ocorre através do contato metálico entre pequenos pontos e protuberâncias de alturas mais elevadas, existentes nas interfaces opostas de centelhamento ${ }^{(19)}$.

Riley $^{(24)}$ demonstrou de forma conclusiva, que a profundidade das irregularidades superficiais ou depressões produzidas nas interfaces dos materiais adjacentes são reduzidas através da redução da tensão de centelhamento.

A tensão de centelhamento não influencia a distribuição de temperatura na interface dos materiais a serem soldados ${ }^{(19)}$, ou seja, a quantidade de calor necessária para fundir um determinado volume de metal é independente da tensão de centelhamento.

\section{e) Corrente Elétrica.}

O aumento da corrente elétrica através de ajustes crescentes da chave seletora do transformador faz a temperatura da junta soldada aumentar. Esta taxa de aumento é bem rápida no início e atinge seu ponto máximo até próximo do início do recalque ${ }^{(25)}$.

\subsubsection{Variáveis de Recalque.}

As variáveis de recalque controlam a taxa de compressão para a execução do forjamento entre as extremidades aquecidas da peça a ser soldada. 


\section{a) Taxa de Compressão.}

Assim que uma distribuição uniforme de temperatura é alcançada nas interfaces adjacentes, inicia-se a etapa de recalque. O porta-eletrodo móvel deve então ser acelerado rapidamente, para que o filme fino de metal fundido nas interfaces de centelhamento possa ser expulso, antes de sua solidificação e respectiva perda de fluidez ${ }^{(19,20)}$.

Como o predomínio de óxidos e impurezas indesejáveis localiza-se no filme fino de metal líquido, faz-se necessário que nenhum resíduo de metal líquido fique retido e disponível para se solidificar na interface da solda ${ }^{(19,20)}$.

Considerando-se que o ponto de fusão dos óxidos de vários metais, incluindo o alumínio, magnésio, titânio, tungstênio, cromo e vanádio, é mais elevado do que o do metal de base, os óxidos tendem a se solidificar na interface e ficar retidos em seu interior, a não ser que sejam expelidos rapidamente ${ }^{(19)}$.

\section{b) Ponto de desligamento da corrente de centelhamento.}

Na maioria das vezes o transformador de soldagem é desligado logo após o início do processo de recalque, e, portanto cortando o fluxo de corrente. Em seções transversais pequenas soldadas em máquinas de maiores capacidades de corrente, o material pode fundir-se, caso o desligamento da corrente seja feito posteriormente ao processo de recalque executar a respectiva compressão. Por outro lado, o desligamento prévio da corrente faz com que o material da interface comece a se solidificar, de forma indesejada, antes que a compressão final possa ocorrer ${ }^{(19)}$. 
Quando não for necessário manter a corrente durante o recalque, o desligamento da mesma deve ser ajustado para ocorrer dentro de um ciclo da frequiência da rede elétrica após o início da compressão $(1 / 60 \mathrm{~s} \text {, considerando-se a freqüência da rede igual a } 60 \mathrm{~Hz})^{(19)}$.

\section{c) Força de Recalque.}

O recalque deve ocorrer quando uma distribuição uniforme de temperatura na interface é atingida pelo centelhamento. Neste estágio, a parte móvel do equipamento de soldagem é comprimida rapidamente contra a parte fixa, para que o metal fundido e os óxidos presentes nas superfícies de centelhamento sejam expelidos para fora da junta, antes que estes possam se solidificar, e desta forma aplicar uma força de recalque enquanto o metal ainda possui plasticidade adequada. $\mathrm{O}$ movimento de compressão deve continuar, com força suficiente para recalcar o metal e proporcionar a junção das duas partes. A força de recalque necessária depende da área da seção transversal da junta, do limite de escoamento do metal quente a ser soldado e da inércia do portaeletrodo móvel ${ }^{(18)}$.

A força de recalque máxima disponível limita a capacidade de uma máquina de solda por centelhamento. Em geral, uma pressão de 70 a $84 \mathrm{MPa}$ é necessária para se fazer o recalque de aços-carbono comuns. Este requisito aumenta para 138 a $207 \mathrm{MPa}$ para aços inoxidáveis, e 207 a $345 \mathrm{MPa}$ para algumas ligas resistentes a altas temperaturas ${ }^{(19)}$. 


\section{d) Velocidade de Recalque.}

O processo de recalque pode ser dividido em duas fases ${ }^{(19)}$. Nippes, Savage, Grotke e Robelotto ${ }^{(28)}$ mostraram que na primeira fase, a parte inicial de recalque, que se inicia no instante da compressão, algo em torno de $50-80 \%$ do processo total, ocorre a uma velocidade relativamente alta. Conforme o recalque prossegue, a resistência do material a deformações adicionais aumenta e, consequientemente, a velocidade do porta-eletrodo diminui rapidamente. $\mathrm{Na}$ segunda fase, a velocidade do porta-eletrodo torna-se mais lenta e se aproxima de uma taxa constante, a qual depende da distribuição de temperatura e da pressão de recalque.

Conforme Savage ${ }^{(19)}$, velocidades de recalque mais altas induzem a menos defeitos de solda em relação às velocidades mais baixas.

Riley $^{(20)}$ relatou que as velocidades de recalque vão de aproximadamente $0,212 \mathrm{~m} / \mathrm{s}$ para máquinas de solda pequenas até $0,085 \mathrm{~m} / \mathrm{s}$ para máquinas grandes.

\section{e) Distância de Recalque.}

A extensão da distância de recalque deve ser suficiente para realizar duas funções ${ }^{(19)}$ :

- Os óxidos e o metal fundido devem ser totalmente expelidos do centro das interfaces para a superfície externa.

- As duas interfaces devem ter contato metal-metal em toda a seção transversal. 
Em geral, quanto mais lisa estiver a interface após o processo de centelhamento, mais fácil será para atender às duas condições anteriores. Depressões profundas, tais como as resultantes da aplicação de tensões de centelhamento elevadas, causam retenção de óxidos e metal fundido na seção transversal e, conseqüentemente, podem impedir de se alcançar o contato metal-metal desejado em todos os pontos das interfaces ${ }^{(19)}$.

A distância de recalque necessária para se obter uma solda por centelhamento perfeita está relacionada à espessura da seção transversal. Presumidamente, uma dimensão (extensão) de recalque igual à $1 / 2$ da espessura da seção transversal deveria ser suficiente para expelir as impurezas do centro desta para as superfícies externas, mesmo sob condições adversas. Entretanto, algumas ligas resistentes ao calor e superligas podem requerer distâncias de recalque da ordem de 1 a 1,25 vezes a espessura da seção, para a respectiva expulsão de óxidos e impurezas $^{(19)}$.

$\mathrm{Na}$ execução de uma solda por centelhamento satisfatória, as variáveis de centelhamento e de recalque devem ser consideradas simultaneamente, uma vez que elas são interrelacionadas ${ }^{(19-20)}$.

\subsubsection{Aplicações do Processo de Soldagem Topo-a-Topo por Centelhamento.}

A soldagem topo-a-topo por centelhamento é usada na indústria aeronáutica para produção de montagem estruturais maciças e tubulares, trens de pouso e anéis de várias dimensões. Aros de rodas, bordas de faróis, trilhos de estruturas e acoplamentos de mecanismos de controle são componentes típicos da indústria automotiva. Outras aplicações incluem soldagem de estruturas nas indústrias automotivas e de construção civil, soldagem topo-a-topo de lâminas de serras de 
fita e junção de brocas de aço rápido, machos de tarraxa e suportes de mandris a hastes de aço baixo carbono e aços ligados. Analogamente, trilhos ferroviários e elos de correntes podem ser unidos também por este processo de soldagem, com grandes ganhos de produtividade ${ }^{(20)}$.

A soldagem topo-a-topo por centelhamento de tubulações marítimas é caracterizada por soldas de alta qualidade de forma consistente, aumento de produtividade e redução de requisitos de mão de obra, em relação a métodos convencionais ${ }^{(29)}$.

\subsection{CARACTERÍSTICAS METALÚRGICAS DAS SOLDAS TOPO-A-TOPO POR CENTELHAMENTO.}

Em uma peça soldada por centelhamento, existem diferenças metalúrgicas significantes entre a microestrutura altamente aquecida do centro da solda e o metal de base que não foi afetado pelo calor. Estas diferenças ocorrem porque existe um elevado gradiente de temperatura entre as extremidades das peças de trabalho e os mordentes eletrodos de fixação. O maior calor é gerado nas faces da solda, devido à ação de centelhamento, enquanto que nas extremidades internas dos eletrodos, o metal está basicamente à temperatura ambiente ${ }^{(20)}$.

\subsubsection{Zona Afetada pelo Calor de Soldas Topo-a-Topo por Centelhamento.}

A zona afetada pelo calor é a região em cada lado da linha de junção que foi aquecida durante a soldagem à temperaturas acima ou dentro da zona de temperatura de transformação da austenita. As partes da peça de trabalho, excetuando-se a solda e a zona afetada pelo calor, permanecem relativamente frias e conduzem o calor para fora da solda. Conseqüentemente, a solda resfria-se a 
uma taxa bem maior do que aquela que seria obtida durante um resfriamento simples ao ar e, em se tratando de aços, resulta em endurecimento, principalmente quando a seção soldada é pequena $^{(20)}$.

Além da alteração de dureza, as regiões da linha central da solda e da zona afetada pelo calor apresentam alterações significativas de microestruturas, em relação ao metal de base. Nestas regiões, a microestrutura do material se torna bem mais grossa, do que no metal de base. Esta zona transformada pela solda abrange uma pequena extensão em aços com baixa temperabilidade e uma extensão maior em aços com alta temperabilidade ${ }^{(20)}$.

Nippes et $\mathrm{al}^{(21)}$ concluíram em sua pesquisa com soldas de topo-a-topo por centelhamento em chapas de aços carbono ligados ao cromo e molibdênio de 6,3mm e 9,5mm de espessuras, que a região que excedeu a temperatura inferior de transformação da austenita foi de no máximo 2,5mm para cada lado da linha central da solda. Isto significa que a austenitização do material foi restrita a uma área de extensão máxima de $5 \mathrm{~mm}$ em relação à linha central da solda.

A microestrutura na linha central da solda é essencialmente a mesma daquela da zona afetada pelo calor, em ambos os lados da linha de junção, exceto pelo tamanho dos grãos. Em todas as ligas, o tamanho de grão na região da solda é maior e vai diminuindo, conforme se afasta da linha de junção em direção ao metal de base ${ }^{(20)}$.

A microestrutura na zona afetada pelo calor de uma solda por centelhamento é determinada pelos seguintes fatores ${ }^{(21)}$ : 
- A temperatura máxima alcançada em um determinado ponto por um determinado período de tempo durante a operação de soldagem.

- A taxa de resfriamento experimentada pelas partes dos materiais previamente aquecidas acima da temperatura crítica de transformação.

- A temperabilidade do aço sendo soldado.

- O efeito do trabalho mecânico resultante da etapa de recalque.

\subsubsection{Dureza das Soldas Topo-a-Topo por Centelhamento.}

Soldas topo-a-topo por centelhamento em aços de baixo teor de carbono laminados a frio apresentam pequenas alterações de dureza, e, portanto, não se faz necessário tratamento térmico posterior para uniformidade da dureza ${ }^{(20)}$.

Variações na dureza na zona afetada pelo calor de um aço de baixo teor de carbono laminado a frio são ilustradas na figura 2.10 (a). A dureza do material na zona afetada pelo calor é inferior àquela do metal de base que não foi aquecido, porque o aquecimento removeu o endurecimento por deformação proveniente da laminação a frio, através do mecanismo de recuperação e recristalização, devido ao aquecimento durante a soldagem. A linha central da solda e os pontos próximos às extremidades externas da zona afetada pelo calor têm dureza um pouco menor do que o restante do material aquecido. Em conseqüência disto, durante o teste de tração, fraturas

podem ocorrer próximas às extremidades externas da zona afetada pelo calor, devido a esta pequena redução de dureza ${ }^{(20)}$. 
A figura 2.10 (b) mostra as variações de dureza na zona afetada pelo calor de um aço ligado ao Cr-Ni-Mo, contendo $\mathrm{C}=0,25$ a $0,28 \%, \mathrm{Cr}=0,60$ a $0,80 \%, \mathrm{Ni}=0,80$ a $1,00 \%$ Mo $=0,50$ a $0,60 \%$, soldado por centelhamento. Pode ser notado que a dureza na ZAC aumenta drasticamente em relação àquela do metal de base original (aprox. 260 VHN) e ultrapassa 500 VHN (48 a 50 HRC) próximo à linha central da solda. A queda de dureza na linha central da solda é causada por descarbonetação. A dureza mais baixa na junta soldada localizou-se além da ZAC, onde foi alcançada uma temperatura um pouco acima da temperatura de revenimento do metal de base original, que é de $650^{\circ} \mathrm{C}^{(20)}$.

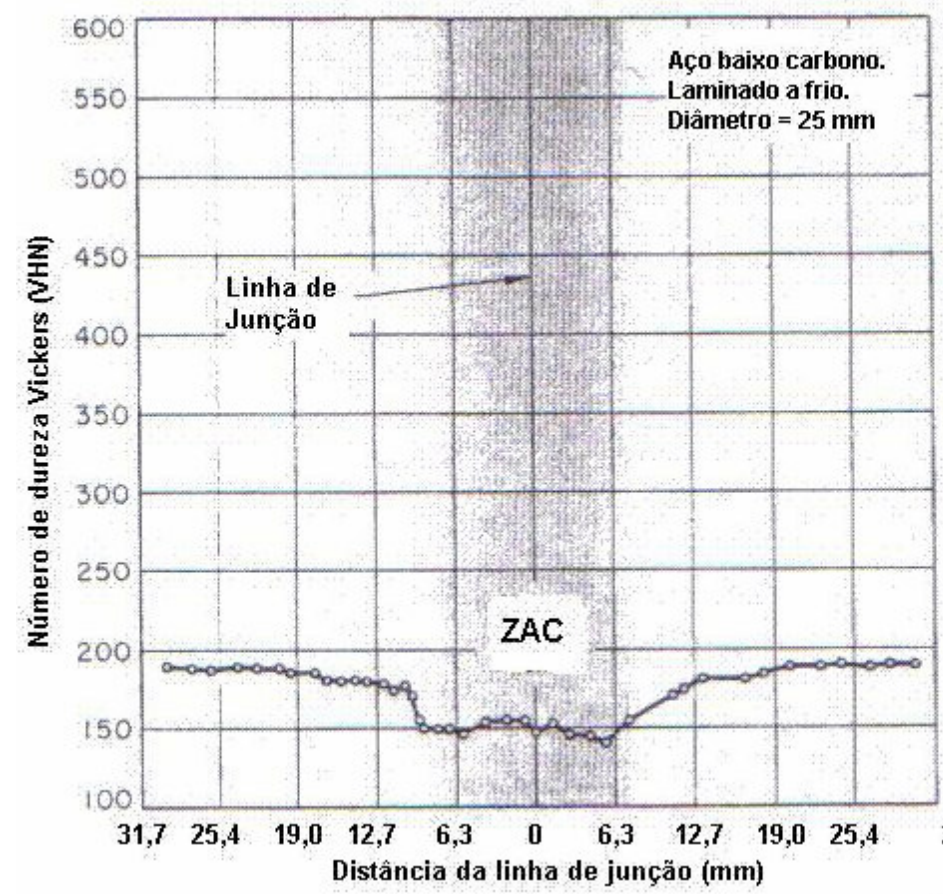

(a)

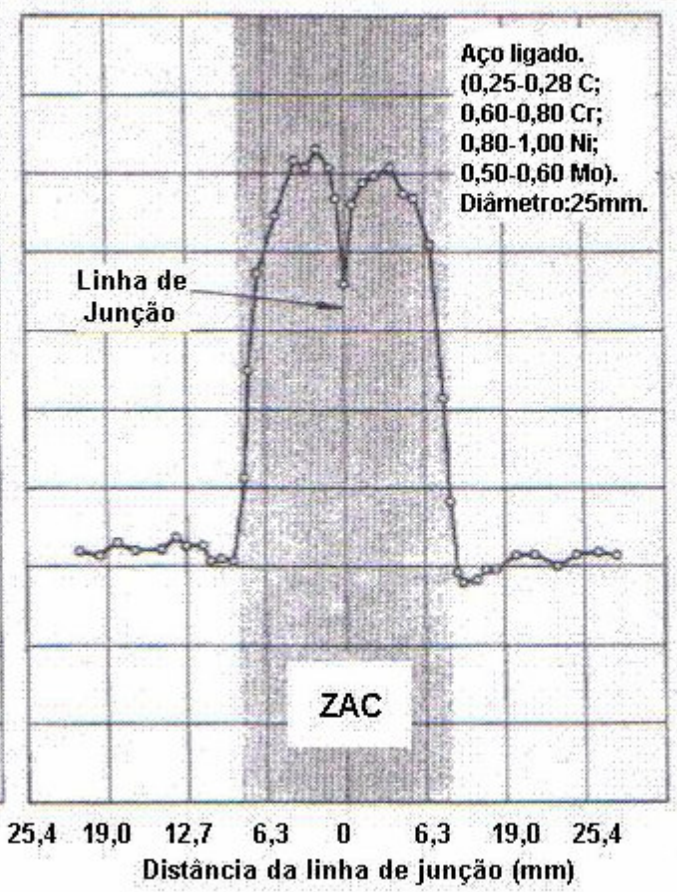

(b)

Figura 2.10 Variação de dureza na ZAC e no metal de base para juntas soldadas por centelhamento sem revenimento em: (a) aço carbono de baixo teor de carbono laminado a frio e (b) um aço ligado ao $\mathrm{Cr}-\mathrm{Ni}-\mathrm{Mo}^{(20)}$. 
Quando aços temperáveis são soldados por centelhamento, consideráveis diferenças de dureza são produzidas na zona afetada pelo calor. Se for desejada uma dureza uniforme, um tratamento térmico pós-soldagem deve ser efetuado ${ }^{(20)}$.

\subsection{REVENIMENTO DAS SOLDAS TOPO-A-TOPO POR CENTELHAMENTO.}

O revenimento das soldas por centelhamento consiste em aplicar uma corrente elétrica através da junta soldada por um curto período de tempo, após a execução da soldagem. Isto irá provocar o aquecimento da zona soldada, com o objetivo de restaurar sua microestrutura e propriedades mecânicas em relação ao metal de base ${ }^{(24)}$.

O revenimento pós-soldagem é um tratamento térmico efetuado a temperaturas abaixo da zona crítica, ou seja, abaixo da região na qual a ferrita se transforma em austenita, para alívio das tensões residuais introduzidas nos materiais durante a soldagem. Estas tensões resultam em zonas endurecidas e são as principais causas de fraturas frágeis na região soldada ${ }^{(30-31)}$.

A zona afetada pelo calor próximo às soldas executadas sem pré-aquecimento, ou com préaquecimento insuficiente, em aços de médio teor de carbono, assim como em muitos aços de alta resistência, resfria-se muito rapidamente, como se tivesse sido temperada. Isto resulta em uma microestrutura martensítica com dureza elevada ${ }^{(30)}$.

A redução de dureza, causada pelo revenimento para alívio de tensões de um aço soldado de médio teor de carbono contendo zonas endurecidas, depende basicamente do tempo de permanência na temperatura do tratamento. Para aços contendo $0,35 \% \mathrm{C}$, após um minuto à 
temperatura de revenimento de $650^{\circ} \mathrm{C}$, a dureza é reduzida de 56 para $27 \mathrm{HRC}$. Após uma hora nesta mesma temperatura, a dureza diminui para 18 HRC, conforme ilustrado no gráfico da figura 2.11. Conforme pode ser verificado na figura 2.11 , a redução de dureza mais significativa ocorre nos primeiros minutos do tratamento térmico de revenimento, para este tipo de aço ${ }^{(30)}$.

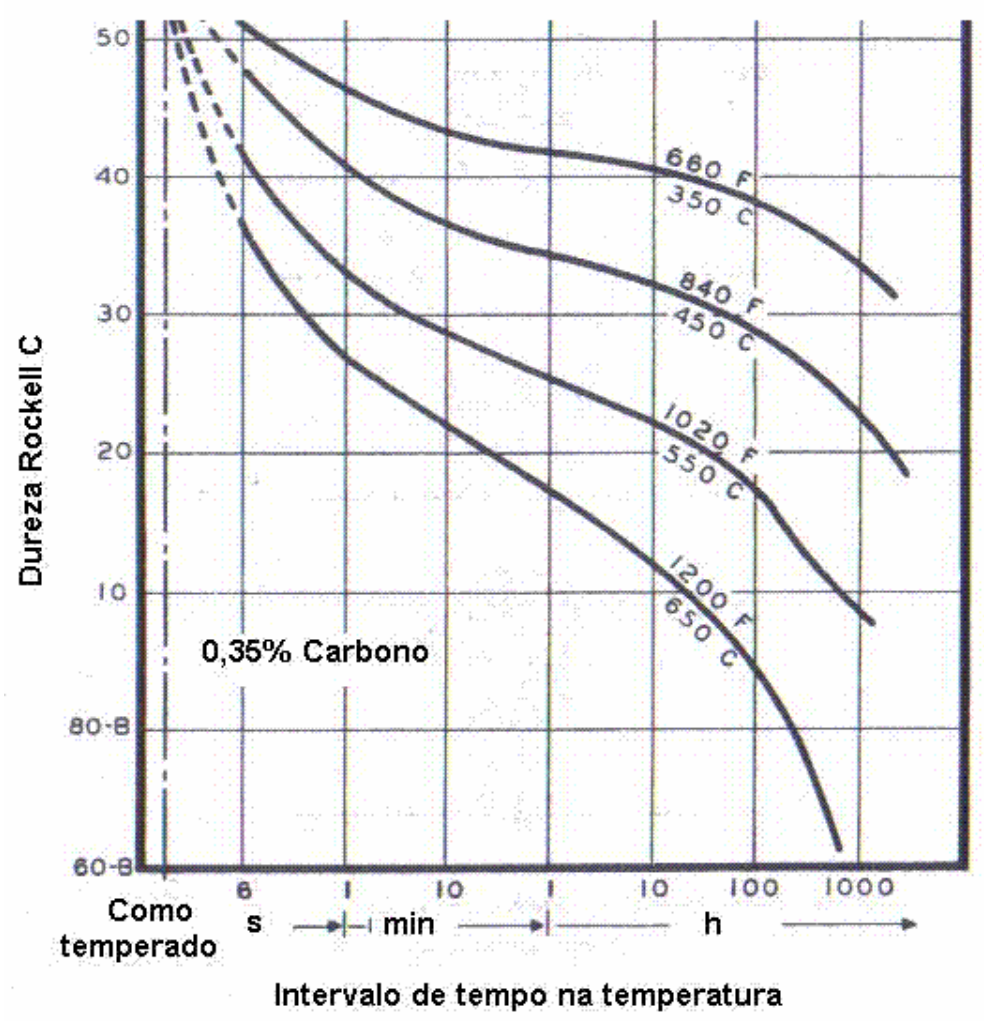

Figura 2.11 Efeito do tempo na redução da dureza de aços temperados com $0,35 \% \mathrm{C}$ em quatro diferentes temperaturas de revenimento ${ }^{(30)}$.

Quando certos tipos de aços contendo elementos formadores de carbonetos, tais como, cromo e molibdênio, são submetidos ao revenimento, pode ocorrer de o material tornar-se mais duro ao invés de mais mole, quando a temperatura de revenimento é aumentada em determinadas regiões, 
conforme ilustrado no gráfico da figura 2.12. O aço $5 \%$ Cr-0,5\% Mo com $0,35 \%$ C é mais duro após o revenimento a $482^{\circ} \mathrm{C}$, do que após o revenimento a $371^{\circ} \mathrm{C}$. Este aumento de dureza é chamado endurecimento secundário e é devido a minúsculos carbonetos complexos, que se formam em altas temperaturas ${ }^{(30)}$. Um exemplo são os carbonetos $\mathrm{M}_{\mathrm{o} 2} \mathrm{C}$ e $\mathrm{M}_{6} \mathrm{C}$, que são prováveis de se formarem na presença de molibdênio.

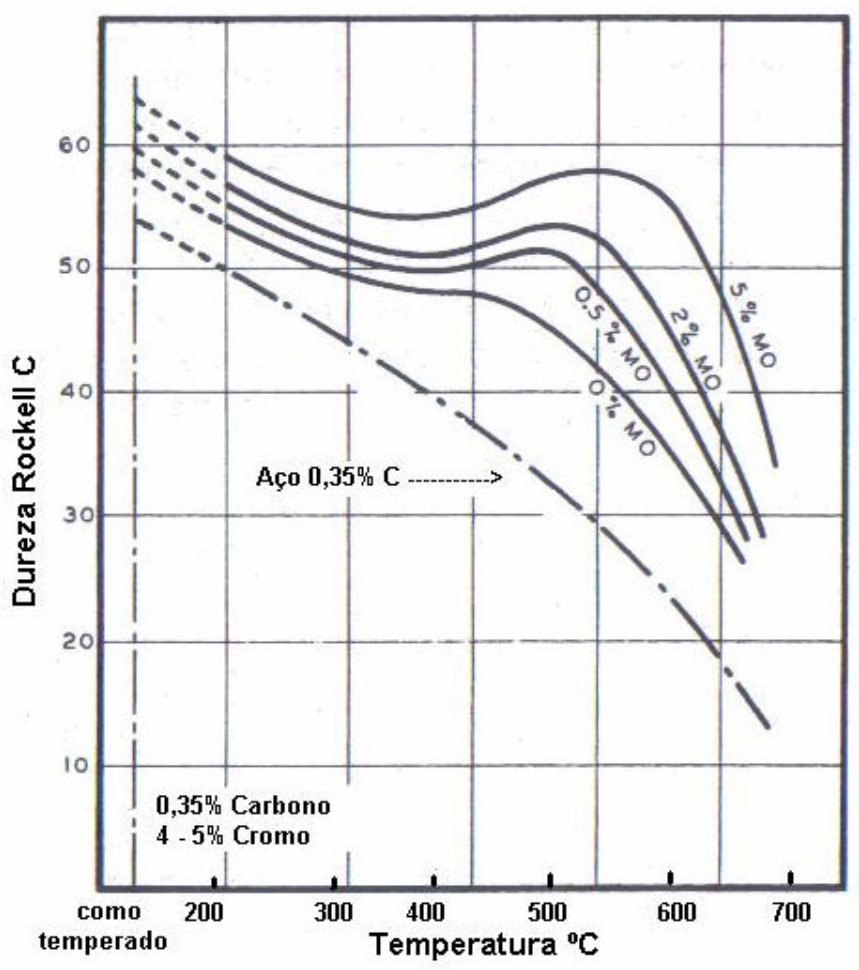

Figura 2.12 Variação da dureza com o aumento da temperatura de revenido em aços com 5\% de cromo contendo $0,35 \%$ de carbono e molibdênio com teores variáveis. A curva tracejada indica um aço com $0,35 \%$ de carbono sem cromo ou molibdênio ${ }^{(30)}$.

A figura 2.13 (a) e (b) mostra uma comparação entre as durezas como soldado e após tratamento térmico de normalização e revenimento para os aços AISI 4340, AISI 4130 e AISI 1020 em 
chapas, que foram soldados por centelhamento usando-se as mesmas condições de soldagem para os três aços. Nota-se que na condição como soldado da figura 2.13 (a), a dureza aumenta acentuadamente na linha central da solda em ambos os aços AISI 4340 e AISI 4130, ao passo que no aço AISI 1020 este aumento não é significativo. Após a normalização e revenimento, conforme mostrado na figura 2.13 (b), a dureza é reduzida e torna-se aproximadamente uniforme em toda a área da solda, exceto para uma pequena queda na linha central da solda ${ }^{(19)}$. O aço AISI 1020 mostrou maior uniformidade na dureza pós-normalização e revenimento.

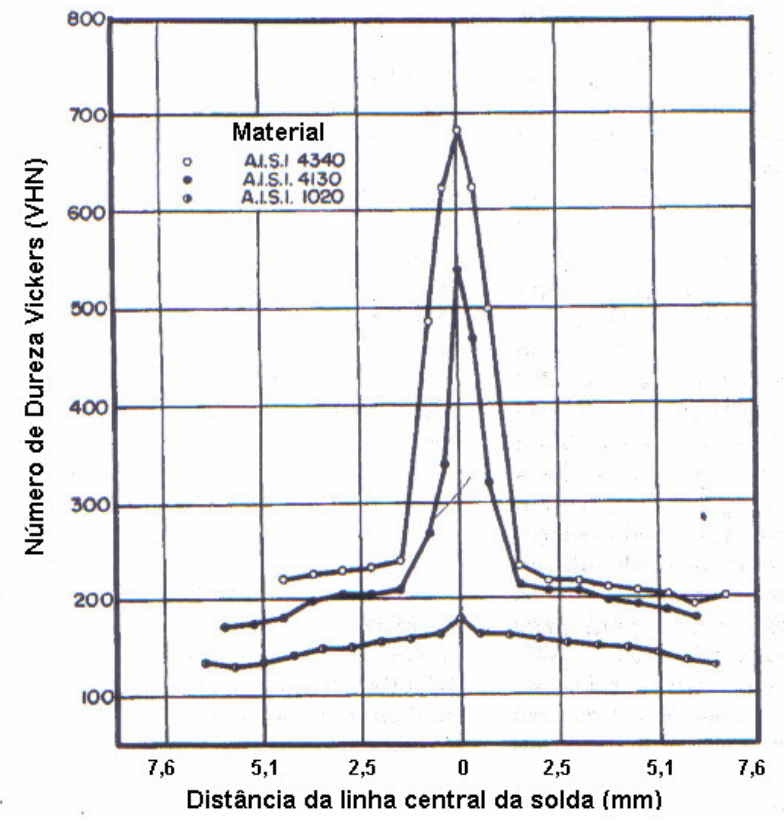

(a)

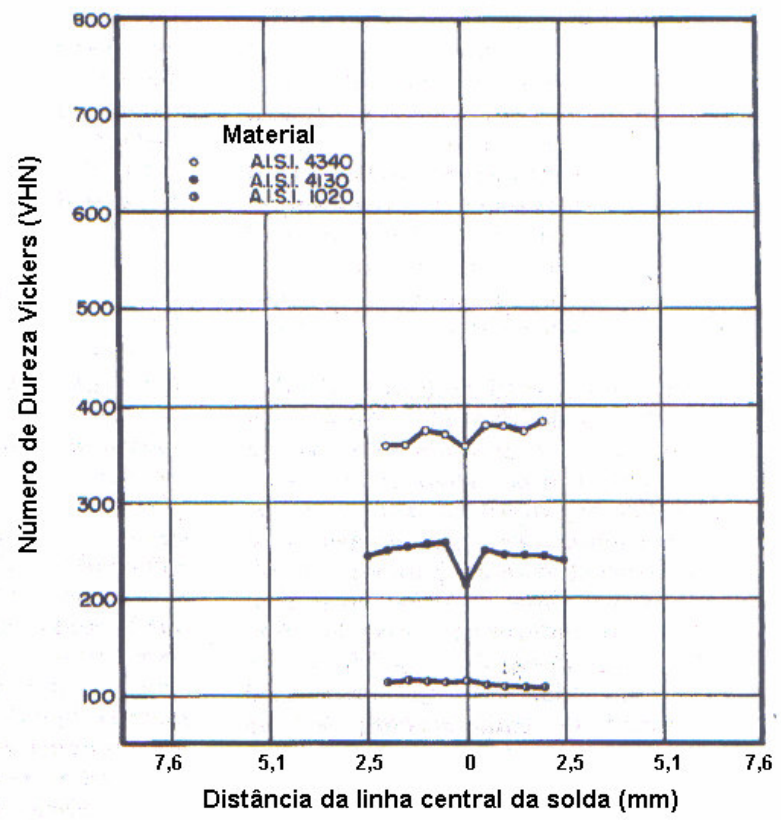

(b)

Figura 2.13 Gráficos de dureza transversal para soldas por centelhamento típicas. (a) conforme soldado. (b) normalizado e revenido após soldagem. Mesmas condições de soldagem para (a) e $(b)^{(19)}$. 
A figura 2.13 revela que uma solda topo-a-topo por centelhamento adequadamente feita, com posterior revenimento, pode resultar em características metalúrgicas semelhantes ou até mesmo melhores em relação àquelas do metal de base, o que pode ser notado pelo aumento da dureza na região da solda. Neste caso o revenimento além de reduzir a dureza após soldagem, contribuiu também para a restauração e uniformidade da microestrutura na região da solda em relação ao metal de base ${ }^{(19)}$.

\subsection{PROPRIEDADES DAS JUNTAS SOLDADAS TOPO-A-TOPO POR CENTELHAMENTO.}

As juntas soldadas pelo processo de centelhamento são particularmente muito interessantes para os projetos de engenharia, pois a resistência e a ductilidade da solda se aproximam daquelas do metal de base. Como não é utilizado metal de adição na execução de uma solda por centelhamento, a solda responde aos efeitos térmicos da mesma forma como o metal de base, apresentando uma microestrutura de forjamento, ao invés de uma microestrutura fundida, característica das soldas por fusão ${ }^{(19)}$.

\subsubsection{Propriedades de Tração e Resistência das Soldas.}

Na soldagem de aços, a força de recalque provoca um desvio na orientação das fibras do material em relação a sua direção normal, conforme ilustrado na figura 2.14, e isto pode causar um efeito de redução em sua resistência mecânica ${ }^{(20)}$. 


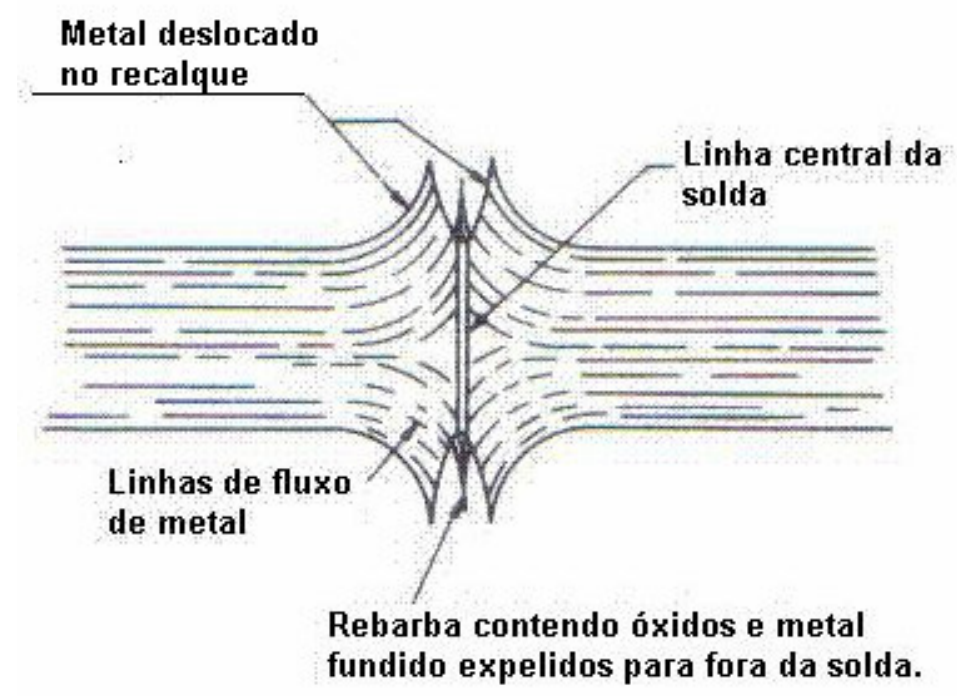

Figura 2.14 Linhas de fluxo de metal e rebarbas típicas de uma solda topo-a-topo por centelhamento $^{(32)}$.

De uma forma geral, um material laminado pode apresentar micro-segregação, que é caracterizada por linhas que atacam de maneira diferenciada na microestrutura do material. Linhas curvadas são formadas próximo à linha central da solda. Elas mostram a deformação plástica nas linhas de fluxo do material, que é provocada pela ação da força de recalque e da temperatura elevada no local. Assim, o material é deformado na direção da linha central da solda, gerando este efeito das linhas curvadas. Na região mais distante da linha central da solda, não existe curvatura, isto é, as linhas são retas e paralelas à direção original de laminação ${ }^{(33)}$.

Savage ${ }^{(19)}$ verificou através de ensaios com o aço AISI 4130, que o redirecionamento das fibras do material devido a força de recalque excessiva, associada a impurezas ou inclusões do metal de base, pode reduzir a resistência à tração das soldas a um valor intermediário entre as resistências à tração no sentido longitudinal e transversal do metal de base original. 
Quando as peças são tratadas termicamente após a soldagem de forma uniforme, a resistência da solda é teoricamente tão alta quanto aquela do metal de base, exceto quando o metal de base tem uma resistência à tração relativamente alta. Se uma peça de aço carbono ou aço ligado soldada por centelhamento for tratada termicamente, de forma que se tenha uma resistência à tração menor do que aproximadamente $1.034 \mathrm{MPa}$, a peça estará completamente homogênea e poderá romper em uma região afastada da linha central da solda. A uma resistência à tração maior do que aproximadamente 1.034 MPa, a fratura é mais provável de ocorrer na linha central da solda, presumivelmente devido a perda de carbono do aço na linha de junção durante a soldagem, ou devido a presença de inclusões ${ }^{(20)}$.

Çetinkaya e Arabaci ${ }^{(26)}$ pesquisaram as propriedades mecânicas do processo de soldagem topo-atopo por centelhamento de elos de correntes em aço 16MnCr5 - EN EC80 (0,143\%C; 1,170\%Mn; $0,188 \% \mathrm{Si} ; 0,010 \% \mathrm{P} ; 0,019 \% \mathrm{~S} ; 1,040 \% \mathrm{Cr} ; 0,030 \% \mathrm{Mo} ; 0,061 \% \mathrm{Ni} ; 0,020 \% \mathrm{Co}$; 0,023\%Al) e concluíram que o aumento da pressão de recalque aumenta a dureza, e conseqüientemente, a resistência à tração da junta soldada, devido à deformação. Cada aumento de 0,05 MPa na pressão de recalque proporcionou um aumento aproximado de $14 \mathrm{MPa}$ na resistência à tração, igualmente em corpos de prova revenidos e não revenidos após a soldagem. A dureza mais alta foi medida na linha central da solda para todas as amostras.

\subsubsection{Propriedades de Fadiga.}

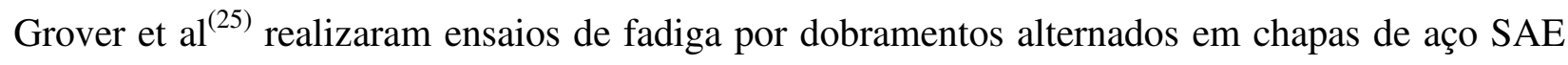
4130 soldadas topo-a-topo por centelhamento. Os resultados indicaram que a solda por centelhamento reduziu a resistência à fadiga por dobramento da chapa. O tratamento térmico de 
revenimento após a soldagem não restaurou a resistência da junta soldada, em relação àquela do metal de base. Os corpos de prova revenidos após a soldagem foram menos resistentes no ensaio de fadiga ao dobramento do que aqueles na condição como soldado.

Os aços de baixa liga e médio teor de carbono (0,3-0,5\%C) são susceptíveis a uma redução significativa da energia de impacto no teste Charpy (CVN) à temperatura ambiente, quando revenidos na faixa de temperatura entre 250 e $400^{\circ} \mathrm{C}$. Este fenômeno é conhecido como fragilidade ao revenido e é devido à relação da formação de carbonetos com alterações no comportamento de endurecimento por deformação da matriz matensítica revenida ${ }^{(34)}$.

\subsection{QUALIDADE DAS SOLDAS TOPO-A-TOPO POR CENTELHAMENTO.}

Defeitos nas soldas topo-a-topo por centelhamento são quase sempre limitados a inclusões de óxidos de ferro na zona de fusão, imperfeições internas ou alterações microestruturais na região soldada ${ }^{(35)}$.

\subsubsection{Efeitos das variáveis de soldagem.}

A qualidade da solda é significativamente afetada pelas variáveis específicas de soldagem, selecionadas para cada aplicação. A tabela 2.3 indica os efeitos de diversas variáveis na qualidade das soldas, quando elas são excessivas ou insuficientes em intensidade. Cada variável é

considerada individualmente, apesar de que mais de uma possam produzir o mesmo resultado ${ }^{(18)}$. 
Tabela 2.3 Efeitos das variáveis na qualidade das soldas por centelhamento ${ }^{(18)}$.

\begin{tabular}{|c|c|c|}
\hline Variável & Excessivo & Insuficiente \\
\hline $\begin{array}{c}\text { Tensão de } \\
\text { Centelhamento }\end{array}$ & $\begin{array}{l}\text { São formadas crateras profundas que } \\
\text { causam vazios e inclusões de óxidos na } \\
\text { solda; metal fundido na solda. }\end{array}$ & $\begin{array}{l}\text { Tendência para solidificar; metal não está } \\
\text { plástico o suficiente para o recalque adequado. }\end{array}$ \\
\hline $\begin{array}{c}\text { Taxa de } \\
\text { Centelhamento }\end{array}$ & Tendência para solidificar. & $\begin{array}{l}\text { Centelhamento intermitente, o que torna difícil } \\
\text { o desenvolvimento do calor suficiente no metal } \\
\text { para o recalque adequado. }\end{array}$ \\
\hline $\begin{array}{c}\text { Tempo de } \\
\text { Centelhamento }\end{array}$ & $\begin{array}{l}\text { Metal muito plástico para recalcar } \\
\text { adequadamente. }\end{array}$ & $\begin{array}{l}\text { Não há plasticidade suficiente para o recalque } \\
\text { correto; trincas no metal recalcado. }\end{array}$ \\
\hline Corrente Elétrica & $\begin{array}{l}\text { Material fundido retido no material } \\
\text { recalcado; deformação excessiva. }\end{array}$ & $\begin{array}{l}\text { Trincas longitudinais na região da solda; } \\
\text { inclusões e vazios não foram corretamente } \\
\text { expelidos para fora da solda. }\end{array}$ \\
\hline $\begin{array}{l}\text { Distância ou Força } \\
\text { de Recalque }\end{array}$ & $\begin{array}{l}\text { Tendência para recalcar excesso de } \\
\text { material no estado plástico; linhas de } \\
\text { fluxo de material dobradas } \\
\text { perpendiculares ao metal de base. }\end{array}$ & $\begin{array}{l}\text { Falha em forçar o metal fundido e os óxidos } \\
\text { para fora da solda; vazios. }\end{array}$ \\
\hline
\end{tabular}

\subsubsection{Microestrutura do metal de base.}

A microestrutura fibrosa inerente de produtos laminados pode causar comportamento mecânico anisotrópico. Uma microestrutura fibrosa orientada para a parte externa na linha central da solda resulta freqüentemente em algum decréscimo nas propriedades mecânicas, quando comparadas com o metal de base, principalmente com relação à ductilidade. Um decréscimo na ductilidade causado pela soldagem por centelhamento é normalmente insignificante, exceto quando a distância de recalque é excessiva. Quando a distância de recalque é excessiva, a microestrutura fibrosa pode ser completamente reorientada transversalmente em relação à estrutura original ${ }^{(18-19)}$. 


\subsection{3. Óxidos e Inclusões.}

A retenção de óxidos na interface da solda constitui uma outra fonte de descontinuidades metalúrgicas. Tais defeitos são raros, uma vez que um recalque adequado deve expelir quaisquer óxidos formados durante as operações de centelhamento ${ }^{(18,19)}$.

Óxidos e inclusões podem estar presentes em juntas que foram soldadas com força de recalque insuficiente para expulsá-los, ou a uma temperatura muito baixa para proporcionar a plasticidade adequada para a região da solda. Apesar das inclusões serem bem pequenas, elas fragilizam a solda. O tratamento térmico não pode removê-las, nem melhorar as propriedades da solda para compensar o efeito da fragilização ${ }^{(20)}$.

\subsubsection{Superaquecimento dos Mordentes.}

Este é um tipo de defeito que é produzido por superaquecimento local do metal de base na interface entre o mordente de fixação e a superfície metálica. Esta forma de defeito pode geralmente ser evitada, através de uma operação de retífica feita em intervalos regulares, para remoção da camada superficial do mordente de fixação que apresentam desgastes, e, desta forma, proporcionar uma resistência de contato superficial baixa na interface metal de base-mordente de fixação $^{(18-19)}$. 


\subsubsection{Porosidades ou vazios.}

Porosidades são raramente encontradas em soldas por centelhamento. Quando ocorrem, geralmente são resultantes de pressão de recalque insuficiente para eliminar todas as depressões formadas durante o centelhamento, ou são decorrentes de tensão de centelhamento excessivamente alta. Depressões profundas nas interfaces de centelhamento produzidas pela ação de centelhamento podem não ser completamente eliminadas, se for utilizado um recalque insuficiente. Tais defeitos são geralmente descobertos durante os testes de qualificação de procedimento de soldagem e podem ser facilmente eliminados, na maioria dos casos, pelo aumento da distância de recalque ${ }^{(18-20)}$.

Algumas vezes, o metal líquido formado na interface de solda pode ser forçado para dentro de um vazio durante o recalque, e pode ser visto como um glóbulo de metal fundido na microestrutura, quando analisado em microscópio ${ }^{(20)}$.

\subsubsection{Trincas.}

As trincas são descontinuidades que podem ser internas ou externas à área de junção e podem ser relacionadas às características metalúrgicas do material. Ligas que apresentam baixa ductilidade em temperaturas elevadas podem ser susceptíveis à trincas internas a quente. Trincas a frio podem ser eliminadas através da soldagem com taxas de resfriamento moderadas, seguida de um tratamento térmico de pós-aquecimento, logo após a soldagem. As trincas externas normalmente são causadas por aquecimento ou recalque inadequado das superfícies adjacentes, e podem ser 
eliminadas pelo aumento da quantidade de calor, através do aumento da corrente elétrica, ou pela aplicação de uma pressão de recalque maior na zona de ligação. ${ }^{(18-20)}$.

Em soldas por centelhamento de peças feitas de aços dissimilares, tais como a soldagem de aços rápidos com aços de médio teor de carbono, deve ser assegurado um resfriamento lento seguido de tratamento térmico, para evitar trincas no aço de maior temperabilidade e também para minimizar os efeitos de fragilidade na zona da solda ${ }^{(20)}$.

\subsubsection{Metal Fundido na Solda.}

Certa quantidade de metal fundido é formada nas superfícies a serem soldadas durante o centelhamento e devem ser expulsas da solda durante o recalque, deixando a área da solda em uma condição homogênea. Entretanto, partes de metal fundido algumas vezes ficam retidas na solda e aparecem como microestrutura fundida no microscópio. Devido ao metal fundido ser provável de conter pequenas trincas de contração e ser de ductilidade menor do que o metal soldado, sua presença deve ser evitada ou reduzida ao mínimo ${ }^{(20)}$.

\subsubsection{Descarbonetação.}

Durante a soldagem por centelhamento, aços de alto teor de carbono perdem carbono ao longo das superfícies de centelhamento, especialmente quando a soldagem é feita ao ar livre. O metal descarbonetado não é totalmente expulso durante o recalque e uma parte deste material pode permanecer na região da solda como uma zona de pontos moles ${ }^{(20)}$. 


\subsubsection{Descontinuidades Mecânicas.}

As descontinuidades mecânicas incluem desalinhamentos das superfícies adjacentes previamente à soldagem e recalque não uniforme durante a soldagem. Estas descontinuidades são facilmente detectadas por inspeção visual. O desalinhamento das peças é corrigido através do ajuste dos mordentes e da pressão de fixação. $O$ recalque não uniforme pode ser causado por desalinhamento da peça, força de fixação insuficiente ou abertura excessiva dos mordentes no início do recalque. Esta última pode ser corrigida pela redução da abertura inicial dos mordentes e pelo ajuste das condições de soldagem ${ }^{(18-19)}$.

\subsection{AÇOS DE BAIXA LIGA E MÉDIO TEOR DE CARBONO.}

Aços carbono de baixa liga constituem uma categoria de materiais ferrosos que apresentam propriedades mecânicas superiores aos aços carbono comuns (baixo carbono, médio carbono e alto carbono), como resultado da adição de determinados elementos de liga como níquel, cromo e molibdênio. O conteúdo total de elementos de liga pode variar de 2,07\% até níveis bem próximos daqueles para aços inoxidáveis, que contêm um mínimo de $10 \%$ de cromo. Para muitos dos aços de baixa liga, a função principal dos elementos de liga é aumentar a temperabilidade, para otimizar as propriedades mecânicas e a tenacidade após o tratamento térmico ${ }^{(36)}$.

Basicamente, as funções dos principais elementos de liga são: o níquel aumenta a resistência ao impacto e à fadiga, o cromo aumenta a resistência à oxidação e à corrosão e o molibdênio aumenta a resistência à temperaturas elevadas ${ }^{(36)}$. 


\subsubsection{Aços de Alta Resistência, Baixa Liga e Médio Teor de Carbono.}

Os aços de alta resistência, baixa liga e médio teor de carbono são aços estruturais que constituem uma subdivisão dos aços de baixa liga e que apresentam uma resistência ao escoamento que pode ultrapassar 1.380 MPa. Muitos destes aços são classificados conforme as denominações SAEAISI e outros são especificações de fabricantes. São fabricados também em chapas finas e fitas enroladas em bobinas, pelos processos de laminação a quente ou a frio, para aplicações que requeiram tratamento térmico ${ }^{(36,37)}$.

Estes aços conciliam elevada resistência mecânica com excelente ductilidade, e foram desenvolvidos principalmente para atender às necessidades das aplicações da indústria aeronáutica, e, posteriormente, se estendeu para outros setores da engenharia. As propriedades mecânicas são conseguidas através de tratamentos térmicos em composições contendo diversos elementos de ligas, em teores geralmente baixos ${ }^{(38)}$.

Esta família de aços inclui os materiais AISI-SAE 4130, 4140, 4340, 6150 e 8640; AMS 6434, 300M e D-6a, cujas composições químicas são mostradas na tabela 2.4. O aço SAE D-6a contém vanádio como refinador de grão, para aumentar a tenacidade. Em relação ao SAE 4340, o SAE D-6a contém teores de carbono, cromo e molibdênio levemente superiores e teor de níquel levemente inferior $^{(39)}$. Os aços $300 \mathrm{M}$ e D-6a são formas derivadas e modificadas do SAE $4340^{(40)}$. 
Tabela 2.4 Composição Química dos aços de alta resistência, baixa liga e médio teor de carbono em $\% \mathrm{p}^{(39)}$.

\begin{tabular}{|l|c|c|c|c|c|c|c|}
\hline $\begin{array}{l}\text { Denominação ou } \\
\text { Marca Comercial }\end{array}$ & $\mathrm{C}$ & $\mathrm{Mn}$ & $\mathrm{Si}$ & $\mathrm{Cr}$ & $\mathrm{Ni}$ & $\mathrm{Mo}$ & $\mathrm{V}$ \\
\hline AISI-SAE 4130 & $0,28-0,33$ & $0,40-0,60$ & $0,20-0,35$ & $0,80-1,10$ & - & $0,15-0,25$ & - \\
\hline AISI-SAE 4140 & $0,38-0,43$ & $0,75-1,00$ & $0,20-0,35$ & $0,80-1,10$ & - & $0,15-0,25$ & - \\
\hline AISI-SAE 4340 & $0,38-0,43$ & $0,60-0,80$ & $0,20-0,35$ & $0,70-0,90$ & $1,65-2,00$ & $0,20-0,30$ & - \\
\hline AMS 6434 & $0,31-0,38$ & $0,60-0,80$ & $0,20-0,35$ & $0,65-0,90$ & $1,65-2,00$ & $0,30-0,40$ & $0,17-0,23$ \\
\hline 300M & $0,40-0,46$ & $0,65-0,90$ & $1,45-1,80$ & $0,70-0,95$ & $1,65-2,00$ & $0,30-0,45$ & $0,05 \mathrm{~min}$ \\
\hline D-6a & $0,42-0,48$ & $0,60-0,90$ & $0,15-0,30$ & $0,90-1,20$ & $0,40-0,70$ & $0,90-1,10$ & $0,05-0,10$ \\
\hline AISI-SAE 6150 & $0,48-0,53$ & $0,70-0,90$ & $0,20-0,35$ & $0,80-1,10$ & - & - & $0,15-0,25$ \\
\hline AISI-SAE 8640 & $0,38-0,43$ & $0,75-1,00$ & $0,20-0,35$ & $0,40-0,60$ & $0,40-0,70$ & $0,15-0,25$ & - \\
\hline
\end{tabular}

Os teores de $\mathrm{P}$ e $\mathrm{S}$ podem variam conforme especificações de fabricantes. Geralmente estes aços não contêm mais do que $0,035 \% \mathrm{P}$ e $0,040 \% \mathrm{~S}$.

Os aços de alta resistência, baixa liga e médio teor de carbono são facilmente forjados a quente, geralmente na faixa de temperatura de 1065 a $1230{ }^{\circ} \mathrm{C}^{(39,41)}$.

\subsubsection{Aço D-6a.}

O aço Ladish D-6a, ou simplesmente D-6a, é um aço de alta resistência, baixa liga e médio teor de carbono, que foi desenvolvido pela empresa Ladish, para aplicações em aeronaves e estruturas para lançamento de mísseis. Este aço apresenta uma resistência à tração à temperatura ambiente no estado laminado de 1.800 a $2.000 \mathrm{MPa}^{(39)}$.

O aço D-6a é produzido em barras de seção transversal retangular e redonda, em peças forjadas e pode ser fabricado como produtos laminados planos (chapas finas e grossas). Estes materiais são usados na fabricação de trens de pouso e componentes estruturais críticos de aeronaves, carcaça de motores para foguetes de propulsor sólido, eixos, engrenagens, molas, matrizes para estampos, etc $^{(39)}$. 


\subsection{AÇOS FERRAMENTAS.}

Aços ferramentas são caracterizados por alta dureza à temperatura ambiente e resistência ao desgaste, assim como, nos tipos mais específicos, alta dureza a temperaturas elevadas com satisfatória tenacidade. Apresentam alta capacidade de corte e de suportarem deformações ${ }^{(41)}$.

Os aços ferramentas geralmente contêm carbono em proporções variando de 0,3 até acima de $1 \%$, juntamente com quantidades significativas de outros elementos de liga em adição ao carbono, tais como cromo, cobalto, manganês, molibdênio, níquel, silício, tungstênio e vanádio. O alto teor de carbono proporciona uma capacidade de endurecimento matensítico acima de 60 HRC. Os carbonetos aumentam a resistência ao desgaste do aço ${ }^{(42)}$.

\subsubsection{Efeitos dos Elementos de Liga nos Aços Ferramentas.}

Os elementos de liga estão envolvidos na formação de vários carbonetos ligados, que aumentam a dureza, a resistência ao desgaste, a resistência ao amolecimento a temperaturas elevadas, ou alguma combinação destas propriedades. A tabela 2.5 mostra os efeitos de vários elementos de liga nas propriedades dos aços ferramenta ${ }^{(42)}$. 
Tabela 2.5 Efeito de vários elementos de ligas nas propriedades dos aços ferramentas ${ }^{(42)}$.

\begin{tabular}{|c|c|c|}
\hline $\begin{array}{l}\text { Elemento } \\
\text { de Liga }\end{array}$ & $\begin{array}{c}\text { Teor } \\
\%\end{array}$ & Efeitos nas Propriedades \\
\hline Carbono & $0,30-2,34$ & Aumenta a dureza e a resistência ao desgaste. \\
\hline Cromo & $0,20-14,00$ & $\begin{array}{l}\text { Aumenta a profundidade de têmpera (em menor grau do que o manganês). } \\
\text { Aumenta a resistência ao desgaste e a tenacidade. } \\
\text { Aumenta a temperatura necessária para têmpera. } \\
\text { Aumenta a resistência ao desgaste e a precisão dimensional. } \\
\text { Aumenta a resistência à corrosão em aços temperados. }\end{array}$ \\
\hline Cobalto & $5,00-12,00$ & $\begin{array}{l}\text { Aumenta a resistência ao amolecimento a temperaturas elevadas. } \\
\text { Aumenta a tendência à descarbonetação. } \\
\text { Reduz a tenacidade. }\end{array}$ \\
\hline Nióbio & $\leq 0,10$ & $\begin{array}{l}\text { Aumenta a resistência ao desgaste. } \\
\text { Aumenta a temperatura máxima permissível para têmpera. } \\
\text { Reduz a tendência à descabonetação. }\end{array}$ \\
\hline Manganês & $0,15-0,30$ & $\begin{array}{l}\text { Aumenta a profundidade de têmpera. } \\
\text { Aumenta a desoxidação dos aços nos estágios finais de fusão. } \\
\text { Reduz a temperatura necessária para têmpera. }\end{array}$ \\
\hline Molibdênio & $0,15-10,00$ & $\begin{array}{l}\text { Aumenta a profundidade de têmpera (mais eficiente que o tungstênio). } \\
\text { Aumenta a dureza a altas temperaturas. } \\
\text { Aumenta a resistência ao desgaste. } \\
\text { Provoca descarbonetação em forjamentos e tratamentos térmicos. } \\
\text { Na presença de silício, aumenta a tenacidade. }\end{array}$ \\
\hline Níquel & $0,29-0,30$ & $\begin{array}{l}\text { Aumenta a tenacidade, a resistência ao desgaste e levemente a profundidade de } \\
\text { têmpera. } \\
\text { Aumenta a dificuldade de revenimento em aços de alta liga. } \\
\text { Reduz a temperatura necessária para têmpera (em pequenas quantidades) }\end{array}$ \\
\hline Enxofre & $0,015-0,05$ & $\begin{array}{l}\text { Aumenta a usinabilidade em alguns aços ferramentas temperadas ao ar. } \\
\text { Por outro lado, é uma impureza prejudicial. }\end{array}$ \\
\hline Silício & $\begin{array}{l}0,15-2,00 \\
>0,30\end{array}$ & $\begin{array}{l}\text { Aumenta a probabilidade de descarbonetação. } \\
\text { Junto com o manganês, molibdênio ou cromo, aumenta substancialmente a resistência } \\
\text { e a tenacidade. } \\
\text { Aumenta a temperabilidade. }\end{array}$ \\
\hline Tungstênio & $\begin{array}{l}0,50-20,00 \\
12,00-20,00\end{array}$ & $\begin{array}{l}\text { Junto com carbono, aumenta a resistência ao desgaste. } \\
\text { Junto com carbono e cromo, aumenta a dureza a altas temperaturas. }\end{array}$ \\
\hline Vanádio & $0,15-5,00$ & $\begin{array}{l}\text { Com molibdênio, cromo e tungstênio: } \\
\text { Aumenta a tenacidade. } \\
\text { Aumenta a dureza a altas temperaturas. } \\
\text { Aumenta a resistência ao desgaste (com médio a alto teor de vanádio). } \\
\text { Aumenta a temperatura máxima permissível para têmpera. } \\
\text { Reduz o crescimento de grãos em aços para tratamento térmico. }\end{array}$ \\
\hline $\begin{array}{l}\text { Alumínio, } \\
\text { Titânio, } \\
\text { Zircônio }\end{array}$ & $\leq 0,10$ & $\begin{array}{l}\text { Aumenta a desoxidação dos aços nos estágios finais de fusão. } \\
\text { Reduz o crescimento do tamanho de grão. }\end{array}$ \\
\hline
\end{tabular}




\subsubsection{Classificação dos Aços Ferramentas.}

Os aços ferramentas são classificados em sete grupos principais pelo Instituto Americano de Ferro e Aço (AISI) e pela Sociedade dos Engenheiros de Automóveis (SAE), conforme a $\operatorname{seguir}^{(42,43)}$ :

- Aços temperáveis em água

- Aços resistentes ao choque

- Aços para trabalhos a frio

- Aços para trabalhos a quente

- Aços rápidos

- Aços para moldes

- Aços para fins especiais

As classificações geralmente são baseadas em tipos de aplicações comuns, composições químicas ou meio de resfriamento (água, óleo ou ar). Estes aços também são produzidos conforme várias especificações ASTM, incluindo ASTM A600, A681 e A686 ${ }^{(42)}$.

\subsubsection{Aços Rápidos.}

São os principais aços utilizados em ferramentas, devido às suas características de alta dureza no estado temperado e retenção da dureza à temperaturas em que a aresta cortante da ferramenta se torna vermelha, devido ao calor gerado na operação de usinagem ${ }^{(44)}$. 
O aço rápido recebe este nome devido à sua capacidade de reter um alto nível de dureza ao cortar metais e outros materiais, em alta velocidade ${ }^{(45)}$.

Os aços rápidos são divididos em dois grupos: tipo molibdênio (séries AISI M) e tipo tungstênio (séries AISI T). Estes aços são altamente ligados e normalmente contém grandes quantidades de molibdênio ou tungstênio, além de cromo, vanádio e algumas vezes cobalto. O teor de carbono varia de 0,75 a $1,5 \%^{(42)}$.

Os aços rápidos do tipo molibdênio classificados conforme as séries AISI M contêm de 3,5 a 9,5\% de molibdênio. Todos contêm um pouco de cromo e alguns têm até $12 \%$ de cobalto. Estes aços são classificados como de endurecimento profundo, possuem boa resistência ao desgaste, são de usinabilidade regular, e de pouca a regular resistência à descarbonetação\% ${ }^{(42)}$.

Os aços rápidos do tipo tungstênio classificados conforme as séries AISI T contêm de 0,75 a 1,5\% de carbono e de 12,0 a 18,0\% de tungstênio. Estes aços têm todas as características daqueles do tipo molibdênio, mas não são recomendados para soldagem devido aos altos teores de tungstênio e de carbono\% ${ }^{(42)}$.

A principal aplicação dos aços rápidos é em ferramentas de corte, mas eles também são empregados na confecção de matrizes de extrusão, ferramentas para polimento e matrizes e punções para cortes e furações ${ }^{(42,45)}$. 


\subsubsection{1. $\quad$ Aço rápido $\mathrm{M42}$}

O aço rápido M42 é um aço ferramenta ligado ao molibdênio, cuja composição química é mostrada na tabela $2.6^{(42)}$.

Tabela 2.6 Composição química do aço rápido M42. Adaptado da tabela "Composição dos Aços Ferramentas Típicos"(42).

\begin{tabular}{|c|c|}
\hline Elemento de Liga & Composição, \%p ${ }^{\text {a) }}$ \\
\hline $\mathrm{C}$ & $1,05-1,15$ \\
\hline $\mathrm{Mn}$ & $0,15-0,40$ \\
\hline $\mathrm{Si}$ & $0,15-0,65$ \\
\hline $\mathrm{Cr}$ & $3,50-4,25$ \\
\hline $\mathrm{Ni}$ & 0,30 max. \\
\hline $\mathrm{V}$ & $0,95-1,35$ \\
\hline $\mathrm{W}$ & $1,15-1,85$ \\
\hline $\mathrm{Mo}$ & $9,00-10,00$ \\
\hline $\mathrm{Co}$ & $7,75-8,25$ \\
\hline
\end{tabular}




\subsection{TEMPERABILIDADE DOS AÇOS DE BAIXA LIGA.}

A temperabilidade é a capacidade do aço ser endurecido em uma determinada profundidade. A máxima dureza obtida em um aço é função do seu teor de carbono, enquanto que a profundidade de endurecimento depende do tamanho de grão e homogeneidade da austenita no instante da têmpera e da presença de elementos de liga. A temperabilidade de um aço pode ser medida por dois métodos mais conhecidos: o "método de Grossmann” e o “ensaio Jominy”(46).

Um material de alta temperabilidade é aquele onde a austenita é capaz de se transformar em martensita sem a ocorrência da formação de perlita ou de outros agregados ferrita-cementita, mesmo com baixas velocidades de resfriamento. Reciprocamente, se um aço necessita de altas velocidades de resfriamento para a formação de martensita, diz-se que sua temperabilidade é baixa $^{(46-47)}$.

\subsubsection{Transformações Microestruturais nos Aços de Baixa Liga.}

A microestrutura dos aços de baixa liga, resultante do resfriamento rápido a partir da temperatura de austenitização com posterior revenimento, é constituída por martensita revenida ou bainita inferior e apresenta boa tenacidade, que é a capacidade de absorver deformações sem ruptura, para um dado nível de resistência desejado para a aplicação. O valor de dureza ou resistência destas microestruturas após têmpera e revenimento é função do teor de carbono dos produtos da transformação da austenita (martensita revenida ou bainita) e não da presença dos elementos de $\operatorname{liga}(41)$ 


\subsubsection{Efeitos do Tratamento Térmico no Aço D-6a.}

O aço D6-a apresenta uma temperabilidade maior que o SAE 4340 e não apresenta fragilidade ao revenido, que é a redução da tenacidade ao impacto na faixa de temperatura de revenimento de 200 a $300^{\circ} \mathrm{C}^{(39,40,48)}$.

\subsubsection{Têmpera do Aço D-6a.}

$\mathrm{O}$ aço D-6a deve ser aquecido até uma temperatura de austenitização de 845 a $940^{\circ} \mathrm{C}$ por 0,5 a 2 horas. Seções com espessuras ou diâmetros até $25 \mathrm{~mm}$ podem ser resfriadas ao ar. Seções maiores podem ser resfriadas em óleo até $65^{\circ} \mathrm{C}$ ou em banho de sais até $205^{\circ} \mathrm{C}$ e então resfriadas em ar. Para melhorar a estabilidade dimensional ou aumentar a tenacidade à fratura, principalmente em peças de sessões grossas, devem ser austenitizadas a $925^{\circ} \mathrm{C}$ e resfriadas dentro do forno ou em banho de sais a $525^{\circ} \mathrm{C}$ e, após a estabilização da temperatura, resfriar em óleo a $60^{\circ} \mathrm{C}$, ou resfriar em banho de sais a $205^{\circ} \mathrm{C}$ (martêmpera), e depois resfriar em ar. A taxa de resfriamento durante a têmpera afeta significantemente a tenacidade à fratura ${ }^{(39,40)}$.

\subsubsection{Revenimento do Aço D-6a.}

O aço D-6a deve ser revenido imediatamente após a têmpera, mantendo-o de 2 a 4 horas na faixa de 315 a $650^{\circ} \mathrm{C}$, dependendo da resistência ou dureza desejada. Um revenimento duplo é recomendado para otimizar a resistência ao escoamento e a tenacidade ao impacto ${ }^{(39,40)}$.

Um alívio de tensões pode ser feito, aquecendo-o até uma temperatura apropriada na faixa de 540 a $675^{\circ} \mathrm{C}$ e mantendo-o nesta condição por 1 ou 2 horas. Posteriormente, resfriar em ar. Para 
material temperado, aliviar a tensão a aproximadamente $25^{\circ} \mathrm{C}$ abaixo da temperatura de revenimento $^{(39,40)}$.

\subsubsection{Propriedades Mecânicas do Aço D-6a após Tratamento Térmico.}

O aço D-6a mantém uma alta relação entre resistência ao escoamento e resistência à tração (92 a 97\%), combinado com uma boa ductilidade, o que pode ser verificado por um alongamento de aproximadamente $8,5 \%$ em $50 \mathrm{~mm}$, e, analogamente, uma redução de área de aproximadamente $27,6 \%$, para uma resistência à tração de até $1.930 \mathrm{MPa}$, conforme tabela 2.7.

Tabela 2.7 Propriedades mecânicas típicas do aço D-6a em barra. Normalizado a $900^{\circ} \mathrm{C}$, temperado em óleo a $845^{\circ} \mathrm{C}$ e revenido em várias temperaturas ${ }^{(39)}$.

\begin{tabular}{|c|c|c|c|c|c|}
\hline $\begin{array}{c}\text { Temperatura } \\
\text { de Revenimento } \\
{ }^{\circ} \mathrm{C}\end{array}$ & $\begin{array}{c}\text { Resistência à } \\
\text { Tração } \\
\mathrm{MPa}\end{array}$ & $\begin{array}{c}\text { Resistência ao } \\
\text { Escoamento } \\
\mathrm{MPa}\end{array}$ & $\begin{array}{c}\text { Alongamento } \\
\text { em 50mm } \\
\%\end{array}$ & $\begin{array}{c}\text { Redução } \\
\text { de Área } \\
\%\end{array}$ & $\begin{array}{c}\text { Energia de Impacto } \\
\text { Charpy-Entalhe em V } \\
\mathrm{J}\end{array}$ \\
\hline 150 & 2.060 & 1.450 & 8,5 & 19,0 & 14 \\
\hline 205 & 2.000 & 1.620 & 8,9 & 25,7 & 15 \\
\hline 315 & 1.840 & 1.700 & 8,1 & 30,0 & 16 \\
\hline 425 & 1.630 & 1.570 & 9,6 & 36,8 & 16 \\
\hline 540 & 1.450 & 1.410 & 13,0 & 45,5 & 26 \\
\hline 650 & 1.030 & 970 & 18,4 & 60,8 & 41 \\
\hline
\end{tabular}

$\mathrm{O}$ aço D-6a apresenta boa tenacidade ao entalhe, ou seja, aproximadamente $18 \mathrm{~J}$ a $-50^{\circ} \mathrm{C}$, para uma resistência à tração em torno de $1.800 \mathrm{MPa}$, conforme mostrado na figura 2.15 , o que resulta em uma alta resistência à cargas de impacto ${ }^{(39)}$. 


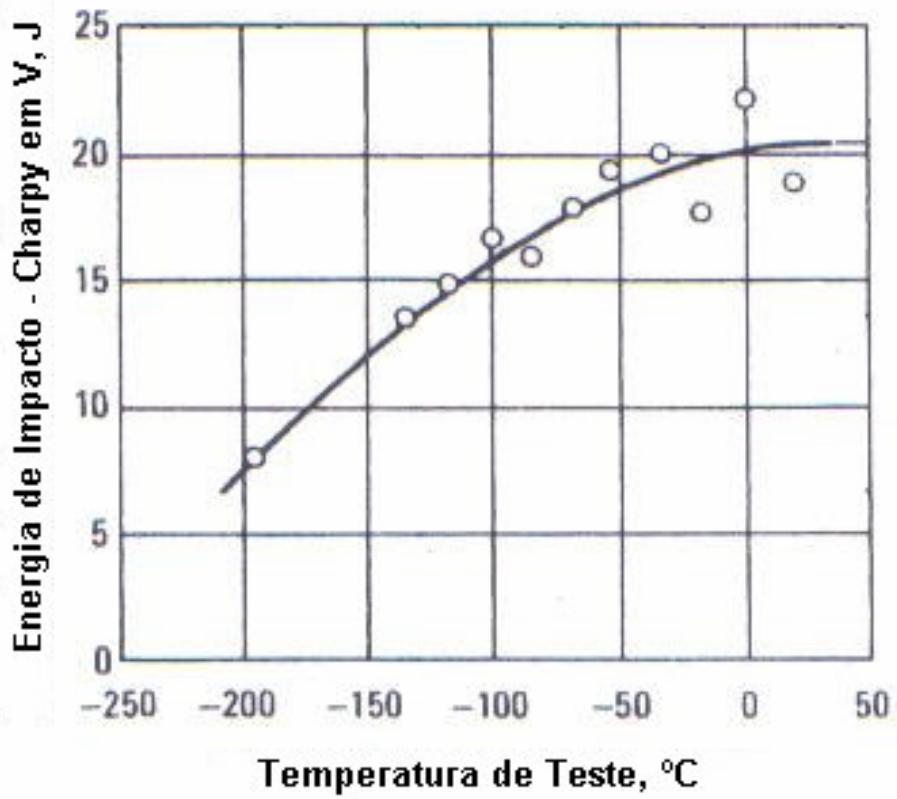

Figura 2.15 Tenacidade à baixas temperaturas do aço D-6a. Todos os corpos de prova foram tratados termicamente até uma resistência à tração à temperatura ambiente de 1.790 a 1.860 MPa. Cada ponto do gráfico é a média de três ensaios ${ }^{(39)}$.

A figura 2.16 mostra o efeito da temperatura de revenimento sobre a dureza à temperatura ambiente, típica de uma barra de aço D-6a. 


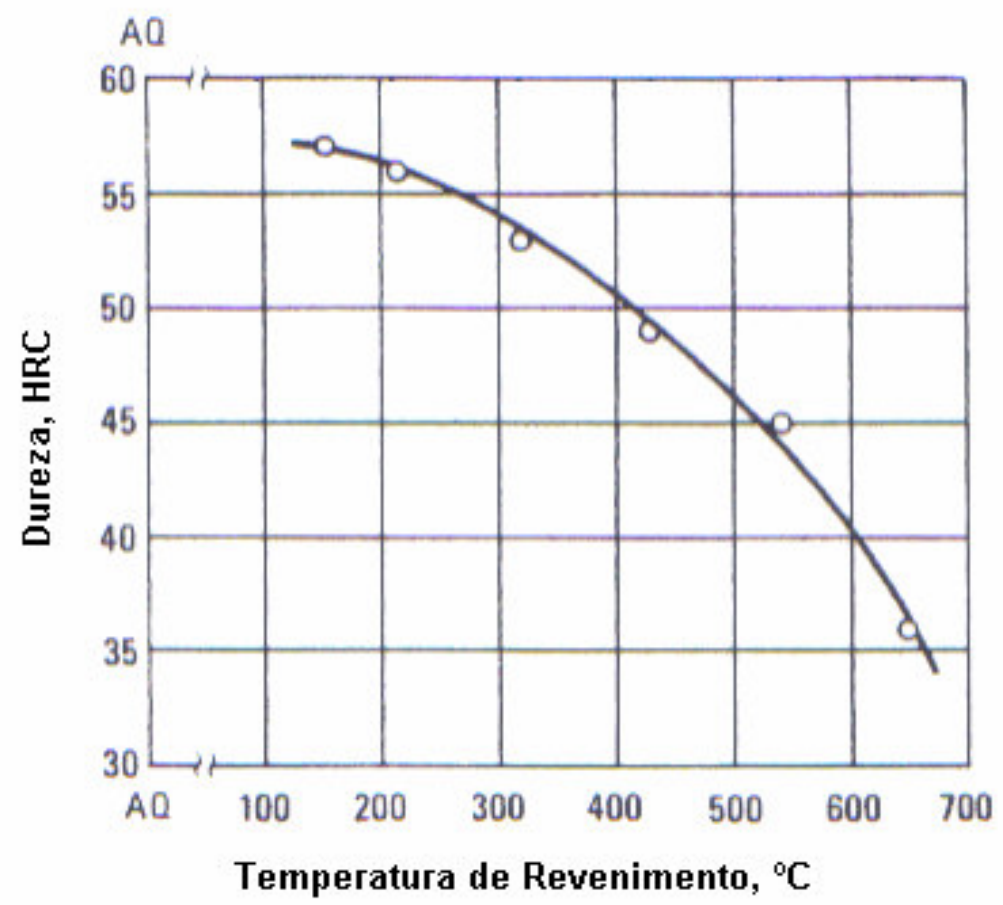

Figura 2.16 Variação da dureza com a temperatura de revenimento para o aço D-6a. Todos os corpos de prova foram temperados em óleo a $845^{\circ} \mathrm{C}$ e revenidos $2 \mathrm{~h}$ na temperatura ${ }^{(39)}$.

Quando revenido a $550^{\circ} \mathrm{C}$ o D-6a apresenta uma dureza aproximada de $43 \mathrm{HRC}$.

\subsection{TEMPERABILIDADE DOS AÇOS RÁPIDOS.}

A temperabilidade dos aços-ferramenta segue as mesmas regras gerais que regem outros aços ligados; ou seja, quanto maior o teor de elementos de liga, maior será a temperabilidade ${ }^{(42)}$. 


\subsubsection{Efeitos do Tratamento Térmico nos Aços Rápidos.}

\subsubsection{Têmpera dos Aços Rápidos.}

Esta operação é executada através de aquecimento lento do aço até uma temperatura acima de sua zona de transformação e mantendo-o à esta temperatura o tempo suficiente para a dissolução dos carbonetos $^{(42)}$.

Vários cuidados devem ser tomados com relação ao aquecimento dos aços-ferramenta à temperatura de austenitização. Primeiramente, o aquecimento deve ser feito em uma atmosfera protetora adequada, ou vácuo, para evitar-se a descarbonetação do aço. Os aços irão descarbonetar-se significativamente em uma atmosfera oxidante, dependendo da temperatura e do tempo. Devem ser evitados tempos longos de permanência à temperatura de austenitização, como prevenção contra crescimento de grãos ${ }^{(42)}$.

O resfriamento é realizado para proporcionar a transformação da austenita em martensita. Os aços-ferramenta são resfriados em água, salmoura, óleo, polímeros, banhos de sais ou ar, dependendo da composição da liga e da espessura da peça. O meio de resfriamento deve resfriar a peça a uma taxa suficiente para obter-se a dureza completa. Entretanto, deve ser evitada uma taxa de resfriamento excessiva, devido ao risco de trincas ${ }^{(42)}$.

Os aços-ferramenta temperados em ar podem ser resfriados até o intervalo de temperaturas entre 538 e $649^{\circ} \mathrm{C}$. A peça de trabalho deve ser retirada do meio de resfriamento, tão logo sua respectiva temperatura tenha estabilizado. Se o tempo de permanência for muito longo, a 
austenita iniciará sua transformação. Após o resfriamento a quente, o aço ferramenta pode ser resfriado em ar ou em óleo até aproximadamente $66^{\circ} \mathrm{C}$, antes de ser revenido ${ }^{(42)}$.

A temperatura final de austenitização para a têmpera é definida pela composição química do aço rápido, e sempre ultrapassam $1100^{\circ} \mathrm{C}$ e, na maioria das vezes, $1200^{\circ} \mathrm{C}$. Tais temperaturas são necessárias para que haja completa dissolução na austenita de todos os carbonetos presentes. É importante que a maioria dos carbonetos se dissolva na austenita, pois assim ter-se-á, na martensita resultante da têmpera, um alto teor de elementos de liga, o que desenvolverá apreciavelmente a dureza a quente dos aços rápidos ${ }^{(44)}$.

O aço rápido pode ser endurecido a um nível de até 1.000 HV ou 65-70 HRC, e consegue manter esta dureza sem que nenhum amolecimento apreciável aconteça até que temperaturas na região de $600^{\circ} \mathrm{C}$ sejam alcançadas ${ }^{(45)}$.

\subsubsection{Microestrutura resultante da têmpera.}

A microestrutura do aço rápido temperado caracteriza-se por apresentar certa quantidade de austenita retida, que é de grande importância no que se refere ao comportamento desses aços durante o revenido. A quantidade de austenita retida depende da temperatura de têmpera. Quando esta se realiza a partir de $1290^{\circ} \mathrm{C}$, tem-se à temperatura ambiente cerca de $20 \%$ a $25 \%$ de austenita retida $^{(44)}$. 


\subsubsection{Distribuição de Carbonetos.}

A natureza e as dimensões das partículas de carbonetos individuais são importantes. Os carbonetos na ferramenta final são provenientes de duas origens principais: carbonetos primários que permanecem após a dissolução das colônias eutéticas, e que não se dissolvem na matriz durante o tratamento térmico, e os carbonetos secundários que precipitam durante o tratamento térmico da matriz, os quais são enriquecidos de carbono devido à solução de partículas pequenas de carbonetos durante a austenitização ${ }^{(45)}$.

O tamanho das partículas de carbonetos e sua distribuição na microestrutura são importantes. Em geral, a preferência é por partículas de carbonetos pequenas, arredondadas e igualmente distribuídas, ao invés de formas irregulares ${ }^{(45)}$.

\subsubsection{Descarbonetação.}

A camada descarbonetada na superfície de uma amostra irá impedir de se obter a dureza total necessária. Além do mais, ela é provável de causar trincas, uma vez que a camada descarbonetada mais fraca é mais propensa a iniciar trincas, as quais podem então se propagar para o interior mais duro do aço. A descarbonetação pode ocorrer principalmente durante as operações de aquecimento a altas temperaturas ${ }^{(45)}$. 


\subsubsection{Revenimento dos Aços Rápidos.}

A microestrutura após têmpera dos aços rápidos é uma mistura heterogênea de austenita retida, martensita virgem e carbonetos. Normalmente é desejável transformar toda a austenita retida para garantir a dureza completa, aumentar a tenacidade e minimizar as distorções durante o serviço. Isto pode ser melhor realizado através de dois ou mais ciclos menores de revenimentos, com resfriamentos entre eles até a temperatura ambiente (figura 2.17), ao invés de apenas um ciclo mais longo ${ }^{(49)}$.

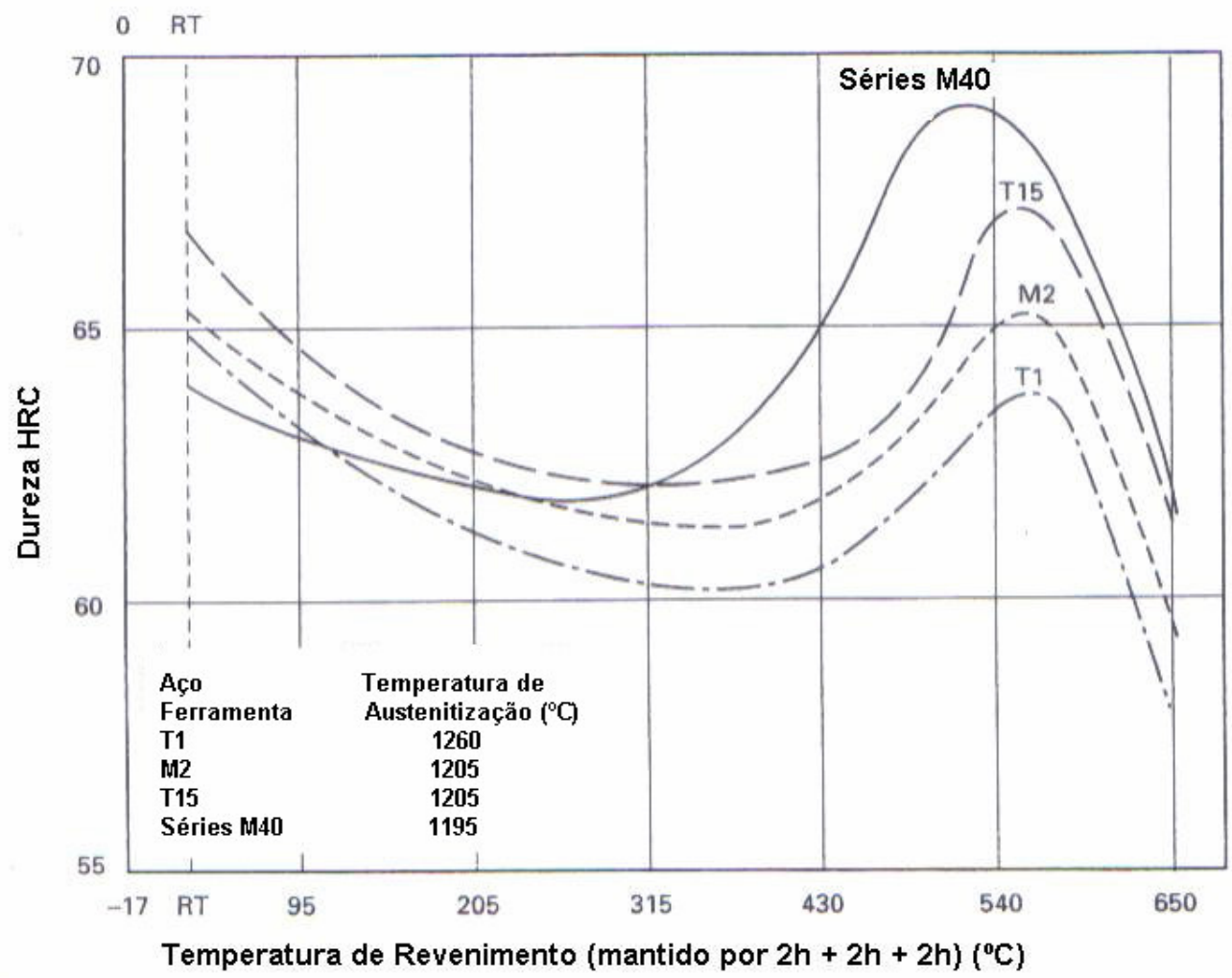

Figura 2.17 Gráfico de dureza x temperatura de revenimento para alguns aços rápidos selecionados, após três ciclos de revenimento de 2 horas cada ${ }^{(50)}$. 
A figura 2.17 mostra os valores de dureza para alguns aços rápidos em relação à temperatura, após três ciclos de revenimento de 2 horas cada. Pode ser notado que estes aços apresentam uma dureza após revenimento mais alta em uma faixa de temperatura de cerca de 500 a $600^{\circ} \mathrm{C}$, em relação a outras temperaturas.

A presença de cobalto nas ligas, tais como no aço rápido M42, reduz a quantidade de austenita retida na condição como temperado e acelera a transformação da austenita retida durante o revenimento $^{(51)}$.

\subsection{METALURGiA DA SOLDAGEM DOS AÇOS DE BAIXA LIGA E AÇOS RÁPIDOS.}

A soldagem consiste no processo de união de duas ou mais partes metálicas, através da utilização de energia térmica. Por esta razão, o material adjacente à zona de soldagem é exposto a ciclos térmicos e transformações metalúrgicas complexas, bem como à indução de deformações e tensões residuais $^{(52)}$.

A soldagem envolve aquecimento, fusão, solubilização, solidificação e resfriamento de um material ou de diversos materiais, dependendo da aplicação do componente soldado. Desta forma, as transformações que ocorrem no aquecimento, as fases formadas durante a fusão, a solidificação e as transformações que ocorrem no resfriamento, determinam o desempenho da junta soldada. Portanto, a metalurgia da soldagem está intimamente ligada à qualidade da junta soldada, bem como ao conceito de soldabilidade ${ }^{(53)}$. 


\subsubsection{Conceito de Soldabilidade.}

Defini-se soldabilidade como sendo a facilidade com que uma junta soldada é executada, de forma a preencher os requisitos de um projeto bem executado. Do ponto de vista metalúrgico, a soldabilidade abrange uma completa avaliação das modificações metalúrgicas que ocorrem na soldagem, como as transformações de fase que ocorrem no aquecimento, na fusão, na solidificação e no resfriamento. Está ainda associada com a natureza do material, com a condutividade térmica e com a transferência de calor na junta soldada ${ }^{(53)}$.

A soldabilidade de um aço carbono é determinada pelo teor de seu carbono equivalente. O carbono equivalente pode ser calculado pela equação 5 (\% em massa), que é bastante empregada e foi desenvolvida pelo Instituto Internacional de Soldagem (IIW). Quanto menor for o carbono equivalente, menor a probabilidade de ser obtida uma microestrutura martensítica, que favorece as trincas por hidrogênio e, conseqüentemente, melhor a soldabilidade do aço, conforme mostrado na tabela $2.8^{(54)}$.

$$
C e q=\% C+\frac{\% M n}{6}+\frac{\% C r+\% M o+\% V}{5}+\frac{\% N i+\% C u}{15}
$$


Tabela 2.8 Tabela indicativa do grau de soldabilidade de aços carbono a partir da determinação do carbono equivalente ${ }^{(54)}$.

\begin{tabular}{|c|c|}
\hline Ceq $<0,40$ & Boa soldabilidade \\
\hline $0,40 \leq \mathrm{Ceq} \leq 0,60$ & Média soldabilidade \\
\hline $\mathrm{Ceq}>0,60$ & Má soldabilidade \\
\hline
\end{tabular}

Um carbono equivalente elevado não é indicador de que o aço não seja soldável, mas sim de que são necessários cuidados cada vez maiores. Segundo a classificação de soldabilidade do aço, quanto menor o carbono equivalente, melhor sua soldabilidade. Todo fator que aumenta a temperabilidade de um aço carbono, favorece a ocorrência de trincas a frio induzidas por hidrogênio $^{(54)}$.

\subsubsection{Soldabilidade dos Aços de Baixa Liga.}

A soldabilidade dos aços carbono de baixa e média liga está bastante associada à presença de trincas a frio induzidas por hidrogênio. Como estão relacionadas à microestrutura na junta soldada, essas trincas são determinadas pela composição química do material. Em outras palavras, a soldabilidade está relacionada com a temperabilidade de um aço; assim, quanto maior for sua temperabilidade, maior a probabilidade de ocorrência dessas trincas ${ }^{(55)}$.

A composição química e as propriedades físicas dos aços de baixa liga podem provocar endurecimento rápido ou fragilização na zona soldada, devido à perda de propriedades mecânicas 
do processo de laminação ou do tratamento térmico anterior à soldagem, devido aos efeitos do resfriamento rápido nestes aços. A possibilidade de trincas pode ser evitada através da redução da taxa de resfriamento após a soldagem, o que pode ser feito através de pré-aquecimento ou pósaquecimento da junta soldada ${ }^{(24)}$.

Os aços de baixa liga podem ser soldados pelo processo topo-a-topo por centelhamento. Em peças de seções transversais pequenas ou finas, o revenimento na própria máquina de solda deve ser usado para aliviar as tensões e reduzir a dureza da solda. A máquina de solda deve ser equipada com controles de corrente e tempos apropriados para permitir a programação do ciclo de revenimento ${ }^{(31)}$.

Madi $^{(56)}$ pesquisou e concluiu que a soldagem topo-a-topo por centelhamento de trilhos ferroviários de aços ligados, tais como $\mathrm{Cr}-\mathrm{Si}-\mathrm{V}$ e $\mathrm{Cr}-\mathrm{V}$, resultou em martensita e bainita na zona afetada pelo calor, devido à temperabilidade destes aços.

A figura 2.18 mostra o efeito do tempo de resfriamento na fração volumétrica da martensita em forma de plaquetas ou lâminas dentro da zona afetada pelo calor de grãos grosseiros de aços de baixa liga. 


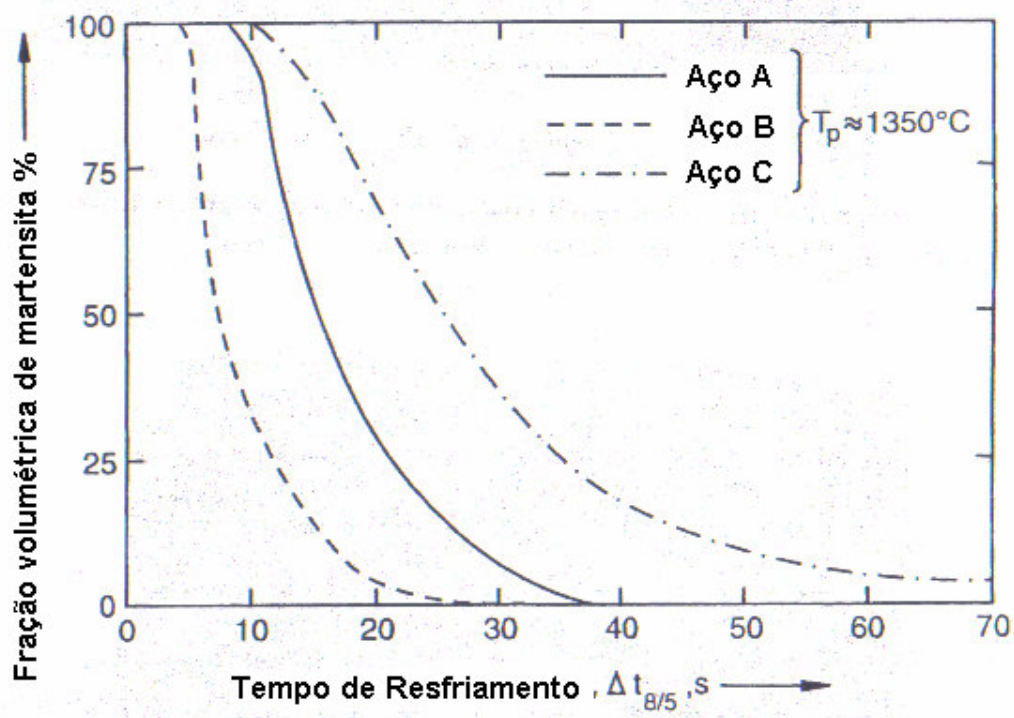

Figura 2.18 Efeito do tempo de resfriamento $\Delta t_{8 / 5}$ na fração volumétrica da martensita em forma de lâminas dentro da ZAC de grãos grosseiros de aços de baixa liga ${ }^{(51)}$.

Conforme mostrado na figura 2.18 a microestrutura será completamente martensítica para valores de $\Delta t_{8 / 5}$ até aproximadamente 5-10 s, dependendo da temperabilidade do aço. A dureza da martensita formada geralmente está abaixo de $400 \mathrm{VHN}$, a qual é significativamente mais baixa do que o valor de pico correspondente alcançado após o resfriamento por água. Isto significa que ocorre um auto-revenimento considerável durante o resfriamento a partir da temperatura Ms, que no caso dos aços de baixa liga de baixo teor de carbono pode atingir $500^{\circ} \mathrm{C}^{(51)}$.

\subsubsection{Transformações Metalúrgicas na Soldagem de Aços de Baixa Liga.}

Durante a soldagem, os materiais da região da solda e da zona afetada pelo calor transformam-se em austenita. Se a área soldada e a zona afetada pelo calor austeníticas são resfriadas rapidamente 
até abaixo da temperatura de transformação apropriada, elas irão transformar-se em martensita ou em uma combinação de martensita e bainita, dependendo da taxa de resfriamento, conforme ilustrado na figura 2.19 para o aço AISI $4340^{(31)}$.

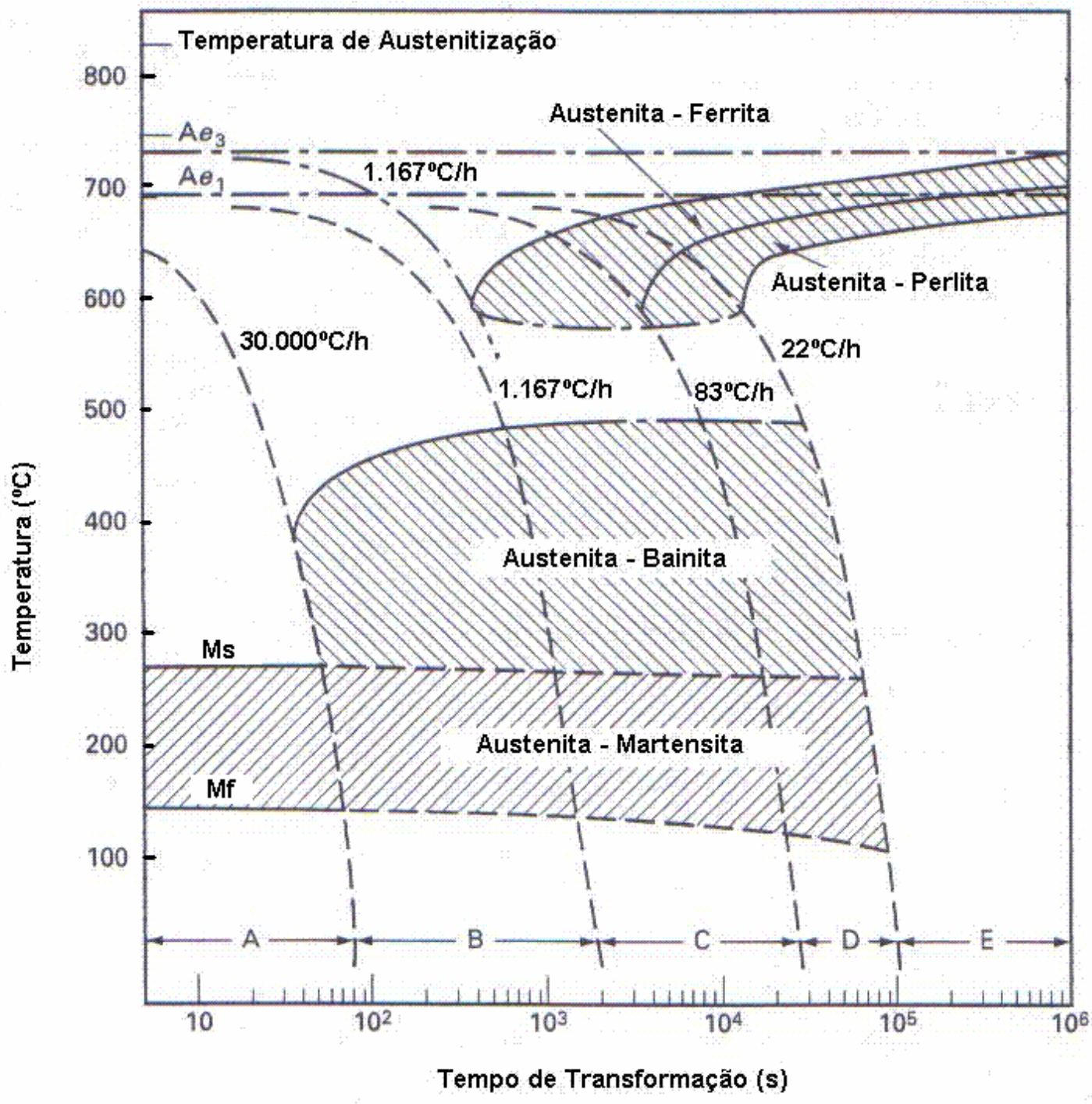

Nota: $A=$ Martensita; $B$ = Martensita, Bainita; $C=$ Martensita, Ferrita, Bainita; $\mathrm{D}=$ Martensita, Ferrita, Perlita, Bainita; $\mathrm{E}=$ Ferrita, Perlita.

Figura 2.19 Diagrama de transformação em resfriamento contínuo para o aço AISI 4340 (31,57). 
Toda taxa de resfriamento que resfrie o aço até a temperatura ambiente em um tempo menor que 90s, irá produzir uma microestrutura $100 \%$ martensítica $^{(57)}$, conforme mostrado na figura 2.19.

A martensita que se forma no resfriamento é uma microestrutura endurecida devido aos efeitos das tensões internas oriundas das contrações da solda e da zona afetada pelo calor e também da transformação da austenita para martensita, mesmo em condições normais de soldagem. No caso dos aços de baixa liga tratáveis termicamente (HTLA), dos quais o D-6a faz parte, esta microestrutura martensítica pode tornar o material mais susceptível à fragilidade por hidrogênio. Portanto, o processo e os procedimentos de soldagem devem ser selecionados para minimizar a presença de hidrogênio durante a soldagem e da mesma forma evitar a formação da martensita ${ }^{(31,58)}$.

A austenita retida resultante do processo de resfriamento pós-soldagem, pode transformar-se em martensita sob a influência das temperaturas dos revenimentos. Esta transformação resulta em um aumento de volume, e nestas circunstâncias pode também causar trincas. Adicionalmente, a nova martensita formada, que constitui uma microestrutura dura e altamente tencionada, irá reduzir a ductilidade e a tenacidade da martensita revenida na microestrutura da matriz revenida ${ }^{(58)}$.

\subsubsection{Soldabilidade do Aço D-6a.}

O aço D-6a é classificado como de difícil soldabilidade, pois apresenta um carbono equivalente igual a $1,03 \%$, calculado conforme equação 5 e composição química da tabela 4.2. Este fato requer normalmente o uso de pós-aquecimento, o que no caso das serras de fita bimetálica caracteriza-se como um revenimento executado na própria máquina de solda. 
O procedimento usado para soldagem topo-a-topo por centelhamento dos aços de baixa liga tratáveis termicamente, que inclui o D-6a, é muito similar ao usado para aços de médio teor de carbono. Em alguns casos, a corrente de soldagem é mais baixa e o tempo de centelhamento é mais longo para compensar a resistência elétrica mais alta de um aço HTLA. Pré-aquecimento e revenimento são recomendados para se evitar trincas de aços que são temperáveis ao ar, quando soldados por centelhamento ${ }^{(58)}$.

\subsubsection{Soldabilidade dos Aços Ferramentas.}

Devido ao teor de carbono e de elementos de liga nos aços-ferramenta, e ao tratamento térmico necessário para atingir as propriedades mecânicas desejadas, o processo de soldagem deve ser realizado por técnicos altamente qualificados, usando-se métodos aprovados e controles do processo. O processo de soldagem afeta significativamente a peça de trabalho na zona afetada pelo calor ${ }^{(42)}$.

O aumento do teor de elementos de liga nos aços-ferramenta diminui a soldabilidade, e isto requer os maiores cuidados durante a soldagem dos aços-ferramenta temperados ao ar. $\mathrm{O}$ principal elemento que influencia a soldabilidade é o carbono; conforme o carbono aumenta, a soldagem torna-se mais difícil. Portanto, o carbono equivalente dos aços (equação 5) é um bom indicador de sua capacidade de soldagem ${ }^{(42)}$. 
Os aços-ferramenta podem ser soldados por processos de centelhamento, antes e depois do tratamento térmico. Mudanças na dureza são restritas a uma zona afetada pelo calor relativamente estreita. Um resfriamento rápido irá retemperar o metal na interface da solda. Pré-aquecimento prévio à soldagem reduzirá a taxa de resfriamento e a zona afetada pelo calor, produzindo uma junta mais dúctil e minimizando a probabilidade de trincas ${ }^{(42)}$. 


\section{OBJETIVOS.}

Os objetivos deste trabalho são:

- Estudar a influência da corrente elétrica, da força de recalque e dos parâmetros do tratamento térmico de revenimento na microestrutura e propriedades mecânicas das soldas topo-a-topo por centelhamento de serras de fita bimetálica.

- Verificar a influência do calor gerado na soldagem topo-a-topo por centelhamento na dureza e microestrutura do aço rápido M42 dos dentes das serras de fita bimetálica. 


\section{MATERIAIS E MÉTODOS.}

\subsection{MATERIAIS.}

Foram utilizados materiais das serras de fita bimetálica, cujas dimensões, composição química e durezas são mostradas nas tabelas 4.1, 4.2 e 4.3, respectivamente.

Tabela 4.1 Dimensões/Especificações da serra de fita bimetálica $27 \mathrm{~mm}$ - 4/6.

\begin{tabular}{|c|c|}
\hline Característica & Dimensão / Especificação \\
\hline Largura & $27 \mathrm{~mm}$ \\
\hline Espessura & $0,9 \mathrm{~mm}$ \\
\hline Passo Variável & 4-6 dentes por 25,4mm \\
\hline Material do corpo & Aço carbono de baixa liga e alta resistência D-6a \\
\hline Material dos dentes & Aço rápido M42 \\
\hline
\end{tabular}

Tabela 4.2 Composição química dos materiais da serra de fita bimetálica $27 \mathrm{~mm}$.

\begin{tabular}{|c|c|c|}
\hline Elemento & D-6a & M42 \\
& $\% \mathrm{p}$ & $\% \mathrm{p}$ \\
\hline $\mathrm{C}$ & 0,47 & 1,06 \\
\hline $\mathrm{S}$ & 0,002 & 0,001 \\
\hline $\mathrm{Si}$ & 0,21 & 0,24 \\
\hline $\mathrm{Mn}$ & 0,73 & 0,21 \\
\hline $\mathrm{Co}$ & - & 7,76 \\
\hline $\mathrm{V}$ & 0,11 & 1,10 \\
\hline $\mathrm{Cr}$ & 0,98 & 3,86 \\
\hline $\mathrm{W}$ & - & 1,22 \\
\hline $\mathrm{Mo}$ & 0,93 & 9,60 \\
\hline $\mathrm{Ni}$ & 0,53 & - \\
\hline
\end{tabular}


Tabela 4.3 Especificação de dureza para serras de fita bimetálica $27 \mathrm{~mm}$.

\begin{tabular}{|c|c|c|c|c|}
\hline \multirow{2}{*}{ Material } & \multicolumn{2}{|c|}{ D-6a } & \multicolumn{2}{c|}{ M42 } \\
\cline { 2 - 5 } & HV & HRC & HV & HRC \\
\hline \multirow{2}{*}{ Dureza } & $434-498$ & $44-49$ & $865-1004$ & $66-69$ \\
\hline
\end{tabular}

\subsection{EQUIPAMENTOS UTILIZADOS.}

\subsubsection{Equipamento de Soldagem.}

Foi utilizado um equipamento para a soldagem topo-a-topo por centelhamento de serras de fita da marca Ideal-Werk, fabricada na Alemanha. As características principais deste equipamento encontram-se relacionadas na tabela 4.4.

Tabela 4.4 Ficha técnica do equipamento de soldagem ${ }^{(59)}$.

\begin{tabular}{|c|c|}
\hline Fabricante & Ideal-Werk \\
\hline Modelo & BAS 100 \\
\hline Ano de fabricação & 1999 \\
\hline Tensão de alimentação & $380 \mathrm{~V}$ \\
\hline Freqüência & $50 / 60 \mathrm{~Hz}$ \\
\hline Potência (Max) & $25 \mathrm{KVA}$ \\
\hline Fator de serviço & $50 \%$ \\
\hline Tensão do secundário (em 6 estágios) & $2,8-3,2-3,6-4,2-4,8-5,5 \mathrm{~V}$ \\
\hline Tipo de corrente & AC - Alternada \\
\hline Faixa de corrente & $4.000-7.857 \mathrm{~A}$ \\
\hline Tensão de comando & $24 \mathrm{~V}-\mathrm{DC}$ \\
\hline Pressão de Fixação Max. & $25 \mathrm{MPa}$ \\
\hline Pressão de Recalque Min. & $0,06 \mathrm{MPa}$ \\
\hline Pressão de Recalque Máx. & $0,55 \mathrm{MPa}$ \\
\hline Fases & Trifásica \\
\hline Dimensões & $600 \mathrm{~kg}$ \\
\hline Peso & $1000 \times 1350 \mathrm{x} 1700 \mathrm{~mm}$ \\
\hline
\end{tabular}




\subsection{PARÂMETROS DE SOLDAGEM.}

\subsubsection{Parâmetros de Soldagem Recomendados para Serras de Fita de $27 \mathrm{~mm}$.}

Os parâmetros de soldagem recomendados para serras de fita bimetálica de $27 \mathrm{~mm}$ de largura encontram-se relacionados na tabela 4.5.

Tabela 4.5 Parâmetros de soldagem recomendados para serras de fita bimetálica de $27 \mathrm{~mm}$ de $\operatorname{largura}^{(59)}$.

\begin{tabular}{|c|c|c|}
\hline PARÂMETROS DE SOLDAGEM & UNIDADE & PROGRAMA 02 \\
\hline Dimensões de chapas (máx) & $\mathrm{mm}$ & $27 \times 0,9$ \\
\hline Chave seletora de soldagem (corrente elétrica) & TAP & 4 \\
\hline Chave de desconexão automática & escala & 3 \\
\hline Pressão de recalque (pneumática) & $\mathrm{MPa}$ & 0,20 \\
\hline Pressão de fixação das peças (hidráulica) & $\mathrm{MPa}$ & 20 \\
\hline Velocidade de centelhamento & $\%$ & 60 \\
\hline Tempo de aquecimento (centelhamento) & $\mathrm{s}$ & 1,6 \\
\hline Tempo de soldagem aprox. (recalque) & $\mathrm{s}$ & 1,5 \\
\hline Distância inicial dos mordentes & $\mathrm{mm}$ & 9,0 \\
\hline Distância final dos mordentes & $\mathrm{mm}$ & $2,2^{ \pm 0,1}$ \\
\hline Tempo de resfriamento (após recalque) & $\mathrm{s}$ & 1,5 \\
\hline Temperatura de revenimento T1 & ${ }^{\circ} \mathrm{C}$ & 630 \\
\hline Tempo de revenimento T1 & $\mathrm{s}$ & 4,0 \\
\hline Intervalo entre T1 e T2 & $\mathrm{s}$ & 1,0 \\
\hline Temperatura de revenimento T2 & ${ }^{\circ} \mathrm{C}$ & 650 \\
\hline Tempo de revenimento T2 & $\mathrm{s}$ & 6,0 \\
\hline Intervalo entre T2 e T3 & $\mathrm{s}$ & 1,0 \\
\hline Temperatura de revenimento T3 & ${ }^{\circ} \mathrm{C}$ & 620 \\
\hline Tempo de revenimento T3 & $\mathrm{s}$ & 4,0 \\
\hline
\end{tabular}




\subsubsection{Parâmetros de Soldagem testados para Serras de fita bimetálica de $27 \mathbf{m m}$.}

Os parâmetros utilizados nos testes de soldagem deste trabalho encontram-se especificados na tabela 4.6 a seguir. Uma tabela mais completa, relacionando a identificação de todos os parâmetros e dos corpos de prova com os ensaios executados, encontra-se no anexo 01.

Tabela 4.6 Parâmetros utilizados nos testes de soldagem de serras de fita bimetálica de $27 \mathrm{~mm}$ de largura.

\begin{tabular}{|c|c|c|c|c|}
\hline $\begin{array}{l}\text { Identif. do } \\
\text { Parâmetro }\end{array}$ & Parâmetro & Variável & Valor & Variação \\
\hline \multirow{3}{*}{ A } & \multirow{3}{*}{ Corrente Elétrica } & Tap 3 & Tensão do Secundário = 3,6 V & $-14,3 \%$ \\
\hline & & Tap 4 & Tensão do Secundário = 4,2 V & $0(\mathrm{R})$ \\
\hline & & Tap 5 & Tensão do Secundário $=4,8 \mathrm{~V}$ & $+14,3 \%$ \\
\hline \multirow{3}{*}{ B } & \multirow{3}{*}{ Força de Recalque } & $0,15 \mathrm{MPa}$ & - & $-25,0 \%$ \\
\hline & & $0,20 \mathrm{MPa}$ & - & $0(\mathrm{R})$ \\
\hline & & $0,25 \mathrm{MPa}$ & - & $+25,0 \%$ \\
\hline \multirow{3}{*}{$\mathrm{C}$} & \multirow{3}{*}{ Quantidade de Revenidos } & Sem Revenido & 0 & 0 \\
\hline & & 3 Revenidos & $\begin{array}{c}\mathrm{T} 1=630^{\circ} \mathrm{C} ; \mathrm{t} 1=4 \mathrm{~s} ; \mathrm{T} 1 / \mathrm{T} 2=1 \mathrm{~s} \\
\mathrm{~T} 2=650^{\circ} \mathrm{C} ; \mathrm{t} 2=6 \mathrm{~s} ; \mathrm{T} 2 / \mathrm{T} 3=1 \mathrm{~s} \\
\mathrm{~T} 3=620^{\circ} \mathrm{C} ; \mathrm{t} 3=4 \mathrm{~s}\end{array}$ & $3(\mathrm{R})$ \\
\hline & & 2 Revenidos & $\begin{array}{c}\mathrm{T} 1=630^{\circ} \mathrm{C} ; \mathrm{t} 1=4 \mathrm{~s} ; \mathrm{T} 1 / \mathrm{T} 2=1 \mathrm{~s} \\
\mathrm{~T} 2=650^{\circ} \mathrm{C} ; \mathrm{t} 2=6 \mathrm{~s}\end{array}$ & 2 \\
\hline \multirow{3}{*}{$\mathrm{D}$} & \multirow{3}{*}{$\begin{array}{c}\text { Temperatura de Revenido } \\
(01 \text { revenido })\end{array}$} & $500^{\circ} \mathrm{C}$ & $\mathrm{T}=500^{\circ} \mathrm{C} ; \mathrm{t}=14 \mathrm{~s}$ & - \\
\hline & & $550^{\circ} \mathrm{C}$ & $\mathrm{T}=550^{\circ} \mathrm{C} ; \mathrm{t}=14 \mathrm{~s}$ & - \\
\hline & & $650^{\circ} \mathrm{C}$ & $\mathrm{T}=650^{\circ} \mathrm{C} ; \mathrm{t}=14 \mathrm{~s}$ & - \\
\hline \multirow{3}{*}{ E } & \multirow{3}{*}{$\begin{array}{l}\text { Tempo de Revenido } \\
\text { (01 revenido) }\end{array}$} & $6 s$ & $\mathrm{~T}=650^{\circ} \mathrm{C} ; \mathrm{t}=6 \mathrm{~s}$ & - \\
\hline & & $10 \mathrm{~s}$ & $\mathrm{~T}=650^{\circ} \mathrm{C} ; \mathrm{t}=10 \mathrm{~s}$ & - \\
\hline & & $18 \mathrm{~s}$ & $\mathrm{~T}=650^{\circ} \mathrm{C} ; \mathrm{t}=18 \mathrm{~s}$ & - \\
\hline
\end{tabular}

$\mathrm{R}=$ valor recomendado $=$ programa $\mathrm{n}^{\mathrm{o}} 02$ da tabela 4.5 .

A variação da corrente elétrica foi feita através da chave seletora do transformador da máquina de solda, onde a posição TAP 4 corresponde ao parâmetro recomendado pelo fabricante, para a soldagem de serras de fita bimetálica de $27 \mathrm{~mm}$. A variação de $\pm 14,3 \%$ em relação ao parâmetro recomendado foi obtida através do posicionamento da chave seletora para TAP 3 e posteriormente para TAP 5. 
A variação da força de recalque foi feita através de ajustes no manômetro do circuito que controla o movimento de compressão do porta-eletrodo móvel da máquina de solda. A força de recalque conforme parâmetro recomendado é obtida com pressão de 0,20 MPa. Foi decidido variar esta pressão para 0,15 e 0,25 $\mathrm{MPa}$, o que corresponde a variações de $\pm 25 \%$ em relação ao valor recomendado.

O tratamento térmico pós-soldagem conforme parâmetro recomendado é feito através de três ciclos de revenimento, cujas temperaturas e tempos são de $630^{\circ} \mathrm{C}$ x $4 \mathrm{~s}, 650^{\circ} \mathrm{C}$ x $6 \mathrm{~s}$ e $620^{\circ} \mathrm{C}$ x $4 \mathrm{~s}$ sucessivamente, com intervalos entre os estágios de 1s. Foi decidido testar a soldagem das serras de fita bimetálica nas seguintes condições: com três revenimentos, sem revenimento, com dois revenimentos e com um revenimento. Para a condição com dois revenimentos foram utilizados os dois primeiros ciclos do parâmetro recomendado. Para a condição de um revenimento foi utilizada a temperatura de $650^{\circ} \mathrm{C}$ associada aos tempos de cada estágio individual do parâmetro recomendado. Também foi testada a condição de um revenimento para as temperaturas de $500^{\circ} \mathrm{C}$ e $550^{\circ} \mathrm{C}$, baseado na temperatura de revenimento apresentado na literatura para o aço D-6a laminado ${ }^{(39)}$, conforme figura 2.16.

\subsection{CARACTERIZAÇÃO MICROESTRUTURAL.}

Foram preparadas 64 amostras para caracterização microestrutural, representando 13 parâmetros diferentes com 02 repetições para cada parâmetro. As amostras foram retiradas conforme item 4.4.1 e analisadas metalograficamente. 


\subsubsection{Critérios para Retirada dos Corpos de Prova.}

Foram retiradas 26 amostras do corpo da serra de fita soldada no sentido longitudinal à LCS, 26 amostras do corpo da serra de fita soldada no sentido transversal à LCS, 10 amostras retiradas dos dentes da serra de fita da região soldada e 02 amostras retiradas dos dentes da serra de fita de uma região que não foi soldada, conforme figura 4.1 abaixo e tabela "Planejamento dos corpos de provas para ensaios de soldagem em serras de fita bimetálica $27 \mathrm{~mm}$ " do anexo 01 .

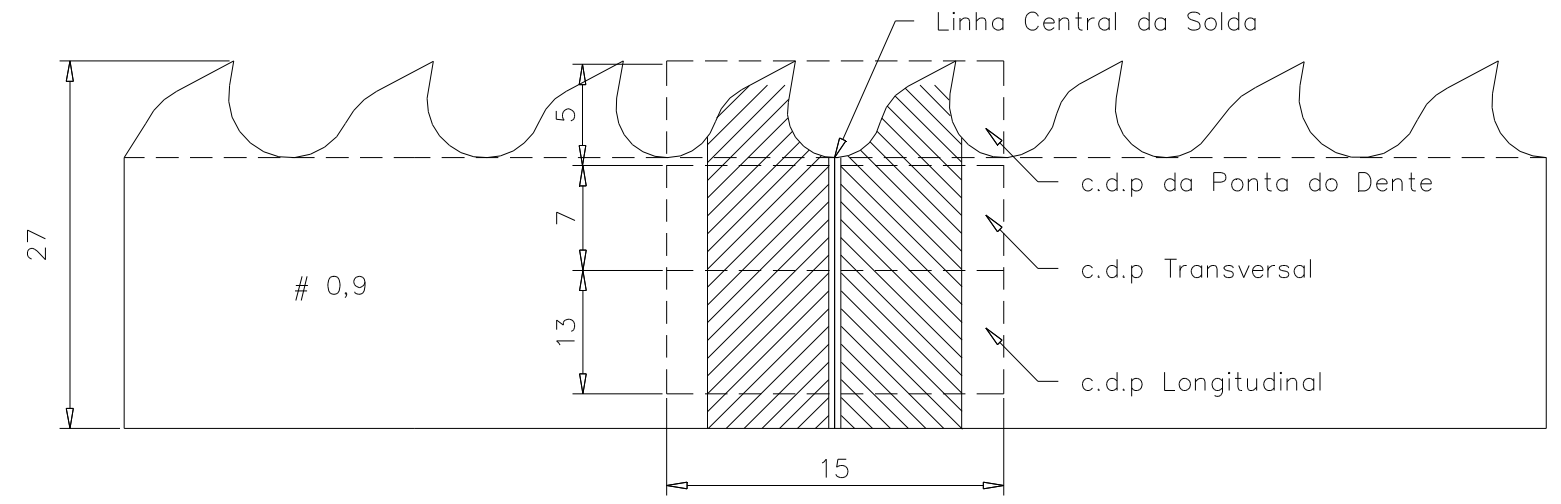

Figura 4.1 Desenho esquemático para retirada das amostras dos corpos de prova.

Após a retirada dos corpos de prova das serras soldadas como testes, as respectivas amostras foram identificadas conforme tabela "Planejamento dos corpos de provas para ensaios de soldagem em serras de fita bimetálica $27 \mathrm{~mm}$ " do anexo 01, e embutidas em baquelite, conforme figura 4.2 a seguir. 

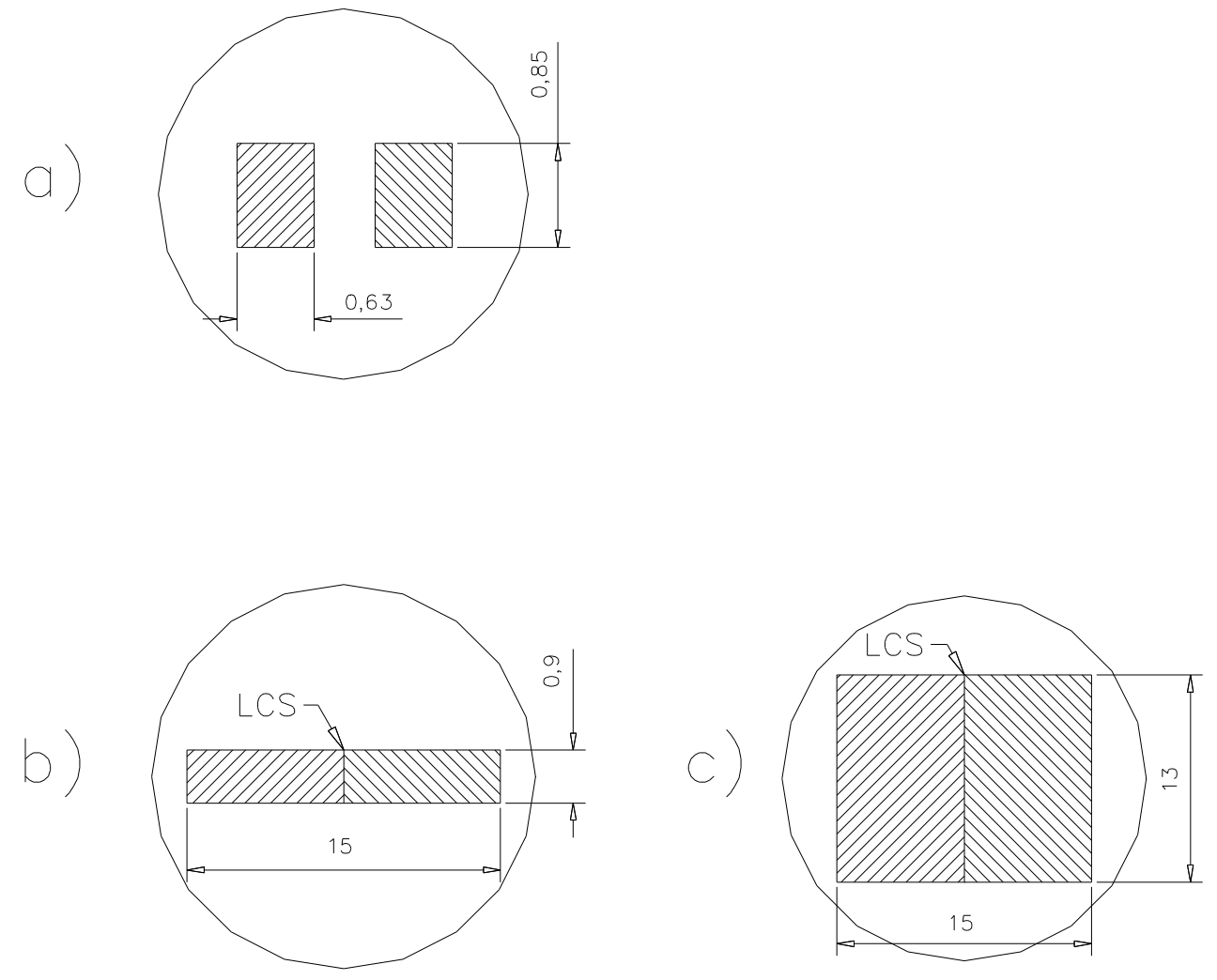

Figura 4.2 Desenho esquemático das amostras embutidas em baquelite: (a) amostra da ponta do dente de aço rápido M42; (b) amostra da seção transversal à LCS e (c) amostra da seção longitudinal à LCS.

As amostras da ponta do dente foram lixadas com lixa \#100 de forma a ser retirado aproximadamente $0,2 \mathrm{~mm}$ da ponta do dente, resultando na seção transversal da figura 4.2(a).

\subsubsection{Equipamentos para Análise Metalográfica.}

Para a análise metalográfica das amostras foram utilizados os recursos de microscopia óptica (MO) Marca: OLYMPUS, tipo BX60M com possibilidade de aumento de até 1.000X e com 
câmera fotográfica eletrônica OLYMPUS BX 60M-35 mm, acoplada ao microscópio. Aumento: 1.000X. Os corpos-de-prova foram cortados e embutidos em baquelite. Em seguida foram lixados com lixas de 120 à 1200 e polidos com pasta de diamante de $3 \mu \mathrm{m}$ a $1 \mu \mathrm{m}$. Após o polimento as amostras foram atacadas com o ácido Villela.

\subsubsection{Equipamentos para Espectroscopia Mossbauer.}

Para a determinação dos espectros Mossbauer das amostras foram utilizados os seguintes instrumentos:

- Transdutor de Velocidade e Gerador de Funções para Mossbauer.

Fabricante: Halder Eletronik.

- Fonte Co 57 com matriz de Rh (atividade de 50mCi)

Fabricante: Ritverc Gmbh, St. Petersburg, Rússia.

- Detector de Raios Gama, do tipo contador Proporcional, pressão de 1 atm, contendo gás $\mathrm{KrCO} 2$.

Fabricante: Reuter-Stokes Inc. (USA).

- Eletrônica para Detecção, Controle de Sinais e Espectroscopia, incluindo PréAmplificador, Amplificador, Fonte de Alta Tensão para o Detector Raios Gama e Placa de Aquisição de Dados para Microcomputador. Fabricante: ORTEC. 


\subsection{ENSAIOS MECÂNICOS PARA AVALIAÇÃO DA JUNTA SOLDADA.}

\subsubsection{Ensaios de Microdureza.}

Foram preparadas 64 amostras para ensaios de microdureza, representando 13 parâmetros diferentes com 02 repetições para cada parâmetro, sendo 26 amostras retiradas do corpo da serra de fita soldada no sentido longitudinal à LCS, 26 amostras retiradas do corpo da serra de fita soldada no sentido transversal à LCS, 10 amostras retiradas dos dentes da serra de fita da região soldada e 02 amostras retiradas dos dentes da serra de fita de uma região que não foi soldada, conforme figura 4.1 e tabela "Planejamento dos corpos de provas para ensaios de soldagem em serras de fita bimetálica 27mm" do anexo 01.

Os ensaios de microdureza Vickers foram realizados com carga de $100 \mathrm{~g}$, conforme indicado na figura 4.3 da página 86.

\subsubsection{Equipamento para Medições de Dureza.}

Equipamento de medida de dureza Vickers empregado foi o Micrômetro Micromet 2100 da empresa Buehler. O equipamento foi calibrado em fevereiro de 2007, com validade até agosto de 2007. 

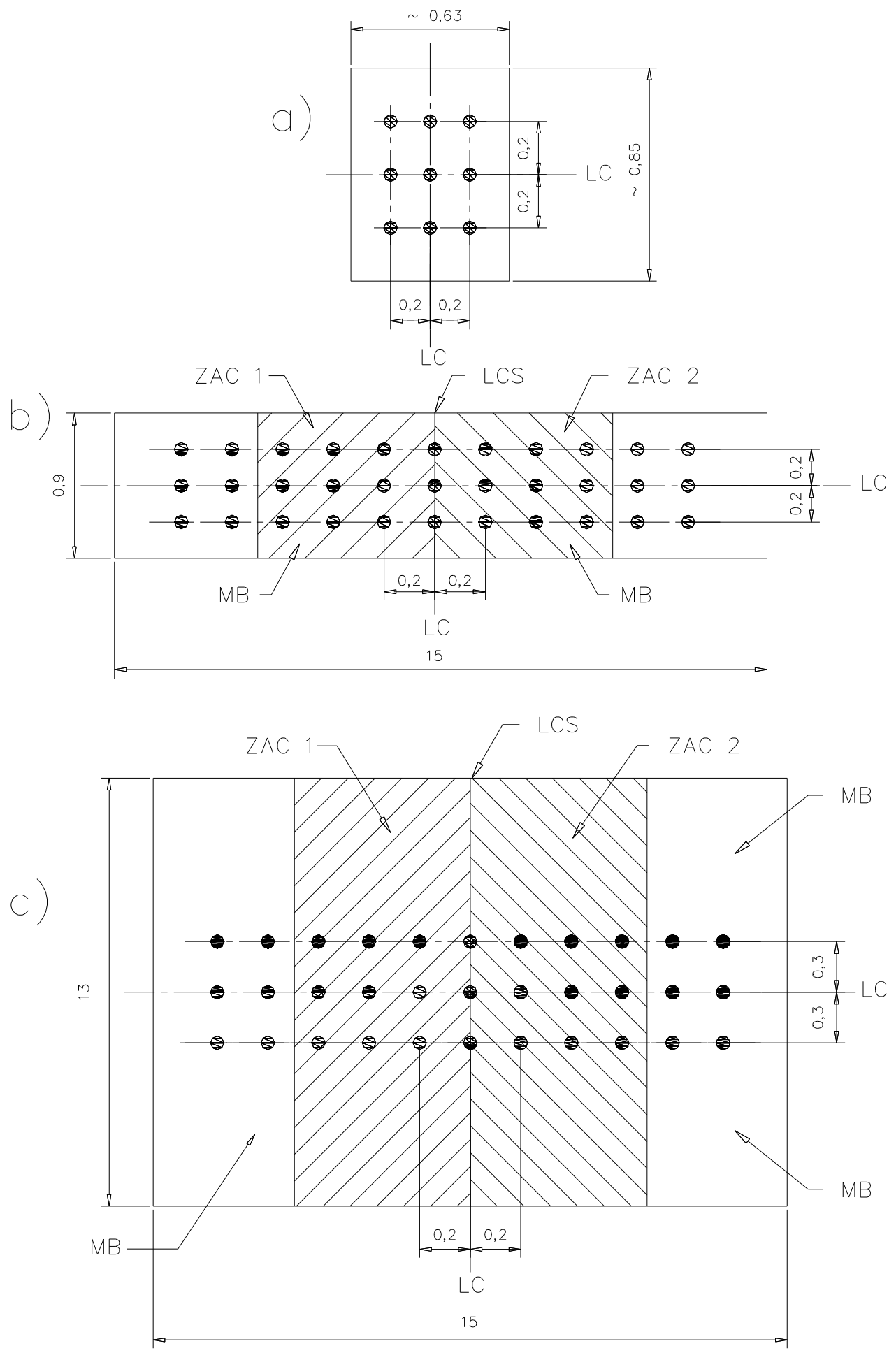

Figura 4.3 Desenho esquemático indicando os pontos de medições de dureza em cada tipo de amostra: (a) microdureza na ponta do dente; (b) microdureza transversal à LCS e (c) microdureza longitudinal à LCS. 


\subsubsection{Equipamento para Análise EDS.}

Para a determinação da composição química das amostras foi utilizada a técnica no MEV de microanálise por dispersão de raios-X (EDS). Esta análise identifica a composição química do material pela energia característica dos elementos, utilizando detectores de estado sólido. O equipamento utilizado foi um microscópio da marca Philips modelo XL-30, com detectores de EDS.

\subsubsection{Ensaios de Torção.}

Foram soldados 39 corpos de prova para ensaios de torção, representando 13 parâmetros diferentes, com 03 repetições para cada parâmetro, conforme figura 4.4 a seguir e tabela "Planejamento dos corpos de provas para ensaios de soldagem em serras de fita bimetálica $27 \mathrm{~mm} "$ do anexo 01 .

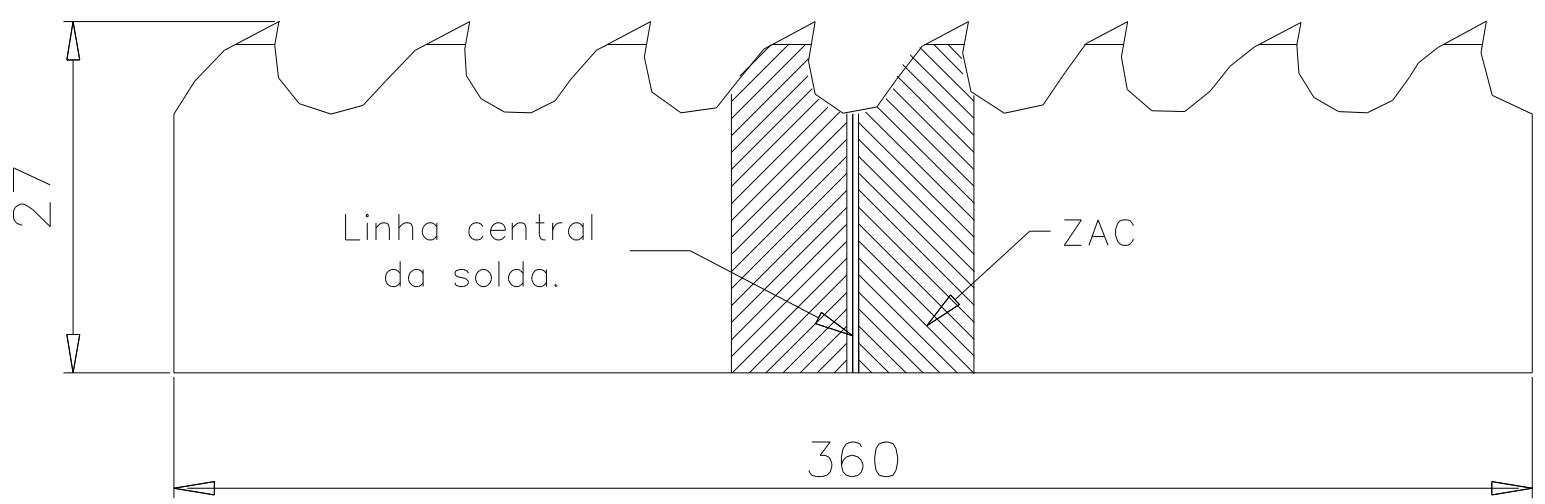

Figura 4.4 Desenho esquemático dos corpos de prova soldados para ensaios de torção. 
Adicionalmente foram preparados 03 corpos de prova, conforme figura 4.4, retirados de segmentos de serras de fita bimetálica, que não foram soldados.

\subsubsection{Equipamentos para ensaios de Torção.}

Para os ensaios de torção foi utilizado um dispositivo de propriedade da empresa Wagner Lennartz \& Simonds International, projetado especificamente para este tipo de ensaio.

\subsubsection{Critério de Aceitação para Ensaios de Torção.}

Os ensaios de torção são executados com os corpos de prova fixados no dispositivo para ensaio de torção citado no item 4.5.2.1, de forma que a LCS fique posicionada no centro da distância entre as fixações das extremidades do corpo de prova da serra de fita soldada.

Conforme procedimento para ensaio de torção da empresa Wagner Lennartz \& Simonds International, o resultado é considerado satisfatório se o corpo de prova soldado suportar uma rotação de $360^{\circ}$ sobre seu eixo, sem apresentar rupturas, trincas ou fissuras na região da solda.

\subsubsection{Técnica para Análise da Superfície Fraturada nos Ensaios de Torção.}

Para a análise das superfícies fraturadas dos corpos de prova dos ensaios de torção foi utilizado um microscópio eletrônico de varredura da marca Philips, modelo XL-30, que permite aumentos de 10 até 100.000 vezes. Também foi utilizada uma lupa estereoscópica marca Zeiss para determinação das áreas dúctil e frágil das regiões das fraturas. 


\subsubsection{Ensaios de Tração.}

Foram soldados 39 corpos de prova para ensaios de tração, representando 13 parâmetros diferentes, com 03 repetições para cada parâmetro, conforme tabela "Planejamento dos corpos de prova para ensaios de soldagem em serras de fita bimetálica $27 \mathrm{~mm}$ ” do anexo 01.

Os corpos de prova para os ensaios de tração foram recortados pelo processo de eletro-erosão a fio, conforme dimensões para corpos de prova de tamanho reduzido especificado pela norma ASTM SA-370. A figura 4.5 mostra as dimensões dos corpos de prova para ensaios de tração, tendo a LCS ao centro.

\section{ENSAIO DE TRAÇÃO \\ CONFORME ASTM SA-370}

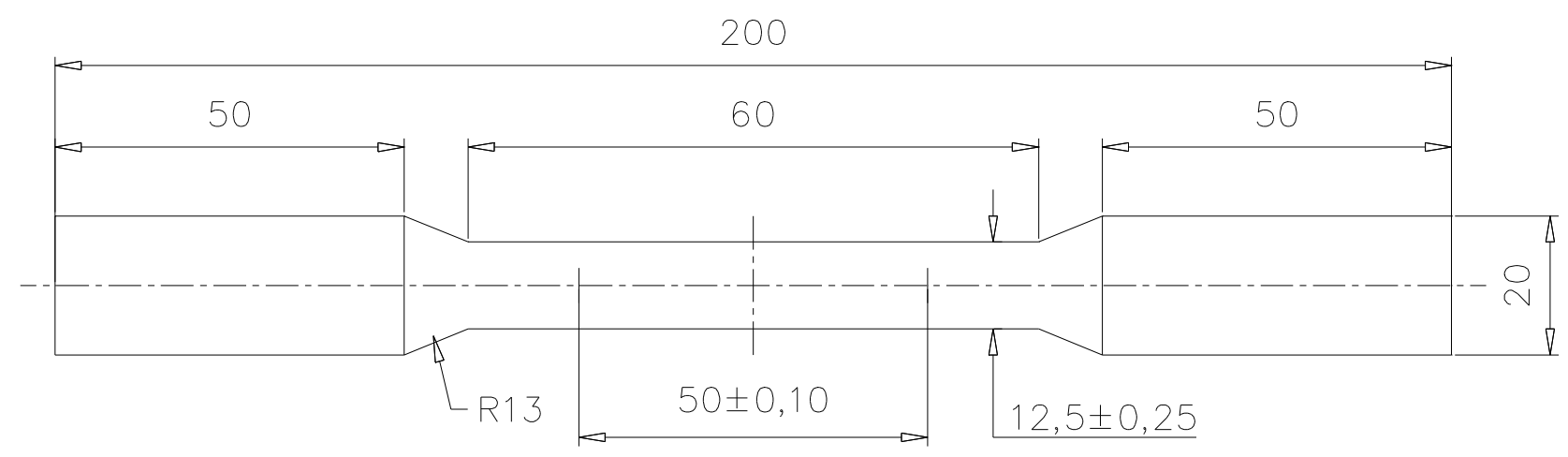

Figura 4.5 Desenho esquemático para usinagem dos corpos de prova de tamanho reduzido para ensaios de tração conforme ASTM SA-370 ${ }^{(60)}$. 
Adicionalmente foram preparados, conforme figura 4.5, 03 corpos de prova retirados de segmentos de serras de fita bimetálica sem soldas, e 03 corpos de prova retirados de segmentos de matéria prima para fabricação de serras de fita bimetálica.

\subsubsection{Equipamento para Ensaios de Tração.}

Para realizar o ensaio de tração foi utilizada a Máquina de Ensaio de Tração de propriedade da Empresa Testin - Tecnologia de Materiais Ltda, marca EMIC, Modelo: DL 10000, com data de calibração de 26.10.06, com validade de 1 ano.

\subsubsection{Técnica para Análise da Superfície Fraturada nos Ensaios de Tração}

Para a análise das superfícies fraturadas das amostras dos ensaios de tração foi utilizado o mesmo microscópio eletrônico de varredura da marca Philips, modelo XL-30, descrito no item 4.5.2.3. Também foi utilizada uma lupa estereoscópica marca Zeiss para determinação das áreas dúctil e frágil das regiões das fraturas. 


\section{RESULTADOS E DISCUSSÃO.}

Conforme apresentado no capítulo anterior, a junção das duas extremidades das serras de fita bimetálica soldadas topo-a-topo por centelhamento foi avaliada por caracterização microestrutural, ensaios de dureza, ensaios de torção e ensaios de tração.

\subsection{CARACTERIZAÇÃO MICROESTRUTURAL DA JUNTA SOLDADA.}

A caracterização microestrutural da junta soldada foi realizada através de análises metalográficas em amostras extraídas transversalmente e longitudinalmente à linha central da solda, e também da ponta dos dentes, pertencentes à região onde foi executada a soldagem, conforme figuras $4.1 \mathrm{e}$ 4.2 e tabela "Planejamento dos corpos de prova para ensaios de soldagem em serras de fita bimetálica de 27 mm”, apresentada no anexo 01.

\subsubsection{Microestrutura da Seção Transversal à Linha Central da Solda.}

A microestrutura da junta soldada no sentido transversal à LCS foi caracterizada por martensita revenida em todas as amostras que foram revenidas após a soldagem ${ }^{(61)}$, com exceção da amostra do parâmetro $\mathrm{C} 1$, que não foi revenida. Neste caso, a microestrutura resultante foi martensita virgem, originária do processo de aquecimento do aço D-6a acima da temperatura crítica durante a soldagem, seguido de resfriamento ao ar. Os resultados das análises microestruturais estão relacionados na tabela 5.1. 
Tabela 5.1 Análise da Microestrutura na Seção Transversal à Linha Central da Solda.

\begin{tabular}{|c|c|c|c|c|c|c|c|c|c|c|}
\hline \multirow{4}{*}{$\begin{array}{c}\text { Identificação } \\
\text { da } \\
\text { Amostra } \\
\end{array}$} & \multicolumn{8}{|c|}{ Análise da Microestrutura na Seção Transversal à Linha Central da Solda. } & & \\
\hline & \multirow{2}{*}{\multicolumn{2}{|c|}{$\begin{array}{c}\text { LCS } \\
\text { Clara e bem definida }\end{array}$}} & \multicolumn{8}{|c|}{$\mathrm{LCS}+\mathrm{ZAC}$} \\
\hline & & & \multicolumn{2}{|c|}{ Martensita Revenida } & \multicolumn{2}{|c|}{ Austenita Retida } & \multicolumn{2}{|c|}{ * Defeitos } & \multicolumn{2}{|c|}{ ** Linhas de Fluxo } \\
\hline & Sim & Não & Sim & Não & Sim & Não & Sim & Não & Regulares & Irregulares \\
\hline A1T1 & $\mathrm{X}$ & & $\mathrm{X}$ & & & $\mathrm{X}$ & & $\mathrm{X}$ & $\mathrm{X}$ & \\
\hline $\mathrm{A} 1 \mathrm{~T} 2$ & $\mathrm{X}$ & & $\mathrm{X}$ & & & $\mathrm{X}$ & & $\mathrm{X}$ & $\mathrm{X}$ & \\
\hline $\mathrm{A} 2 \mathrm{~T} 1$ & $\mathrm{X}$ & & $\mathrm{X}$ & & $\mathrm{X}$ & & & $\mathrm{X}$ & $\mathrm{X}$ & \\
\hline $\mathrm{A} 2 \mathrm{~T} 2$ & $\mathrm{X}$ & & $\mathrm{X}$ & & & $\mathrm{X}$ & & $\mathrm{X}$ & $\mathrm{X}$ & \\
\hline A3T1 & & $\mathrm{X}$ & $\mathrm{X}$ & & & $\mathrm{X}$ & & $\mathrm{X}$ & $\mathrm{X}$ & \\
\hline A3T2 & & $X$ & $\mathrm{X}$ & & & $\mathrm{X}$ & & $\mathrm{X}$ & $\mathrm{X}$ & \\
\hline B1T1 & $\mathrm{X}$ & & $\mathrm{X}$ & & & $\mathrm{X}$ & & $\mathrm{X}$ & $\mathrm{X}$ & \\
\hline $\mathrm{B} 1 \mathrm{~T} 2$ & $X$ & & $\mathrm{X}$ & & & $\mathrm{X}$ & & $X$ & $X$ & \\
\hline B3T1 & & $X$ & $\mathrm{X}$ & & & $\mathrm{X}$ & & $\mathrm{X}$ & $X$ & \\
\hline B3T2 & & $X$ & $X$ & & & $\mathrm{X}$ & & $X$ & $X$ & \\
\hline C1T1 & $X$ & & & $X$ & & $X$ & & $X$ & $\mathrm{X}$ & \\
\hline $\mathrm{C} 1 \mathrm{~T} 2$ & $X$ & & & $X$ & & $X$ & & $X$ & $X$ & \\
\hline C3T1 & $X$ & & $X$ & & & $X$ & & $X$ & $X$ & \\
\hline $\mathrm{C} 3 \mathrm{~T} 2$ & $X$ & & $\mathrm{X}$ & & & $\mathrm{X}$ & & $\mathrm{X}$ & $\mathrm{X}$ & \\
\hline D1T1 & $X$ & & $X$ & & $X$ & & & $X$ & $X$ & \\
\hline D1T2 & $\mathrm{X}$ & & $\mathrm{X}$ & & & $\mathrm{X}$ & & $\mathrm{X}$ & $\mathrm{X}$ & \\
\hline D2T1 & $X$ & & $X$ & & & $X$ & & $X$ & $X$ & \\
\hline $\mathrm{D} 2 \mathrm{~T} 2$ & $X$ & & $X$ & & $X$ & & & $\mathrm{X}$ & $\mathrm{X}$ & \\
\hline D3T1 & $X$ & & $X$ & & $X$ & & & $X$ & $X$ & \\
\hline D3T2 & $X$ & & $X$ & & $X$ & & & $X$ & $X$ & \\
\hline E1T1 & $X$ & & $\mathrm{X}$ & & & $X$ & & $X$ & $\mathrm{X}$ & \\
\hline E1T2 & $X$ & & $X$ & & & $\mathrm{X}$ & & $X$ & $X$ & \\
\hline E2T1 & $\mathrm{X}$ & & $X$ & & & $\mathrm{X}$ & & $\mathrm{X}$ & $X$ & \\
\hline E2T2 & $X$ & & $X$ & & & $X$ & & $X$ & $X$ & \\
\hline E3T1 & $X$ & & $X$ & & & $X$ & & $X$ & $X$ & \\
\hline E3T2 & $\mathrm{X}$ & & $X$ & & & $\mathrm{X}$ & & $X$ & $X$ & \\
\hline
\end{tabular}

* Óxidos, porosidades, trincas, etc.

** Linhas de fluxo regulares apresentam raios de curvatura próximo à LCS.

\subsubsection{Linha Central da Solda.}

Quase todas as amostras apresentaram uma linha fina, clara, reta e bem definida no centro da solda das duas extremidades da serra de fita, em contraste com a ZAC. Esta linha é a interface da solda, ou seja, onde ocorreu a fusão das duas extremidades do material. Esta característica está 
em conformidade com o observado na literatura para o processo de soldagem topo-a-topo por centelhamento $^{(33,61)}$. A figura 5.1 ilustra esta característica.

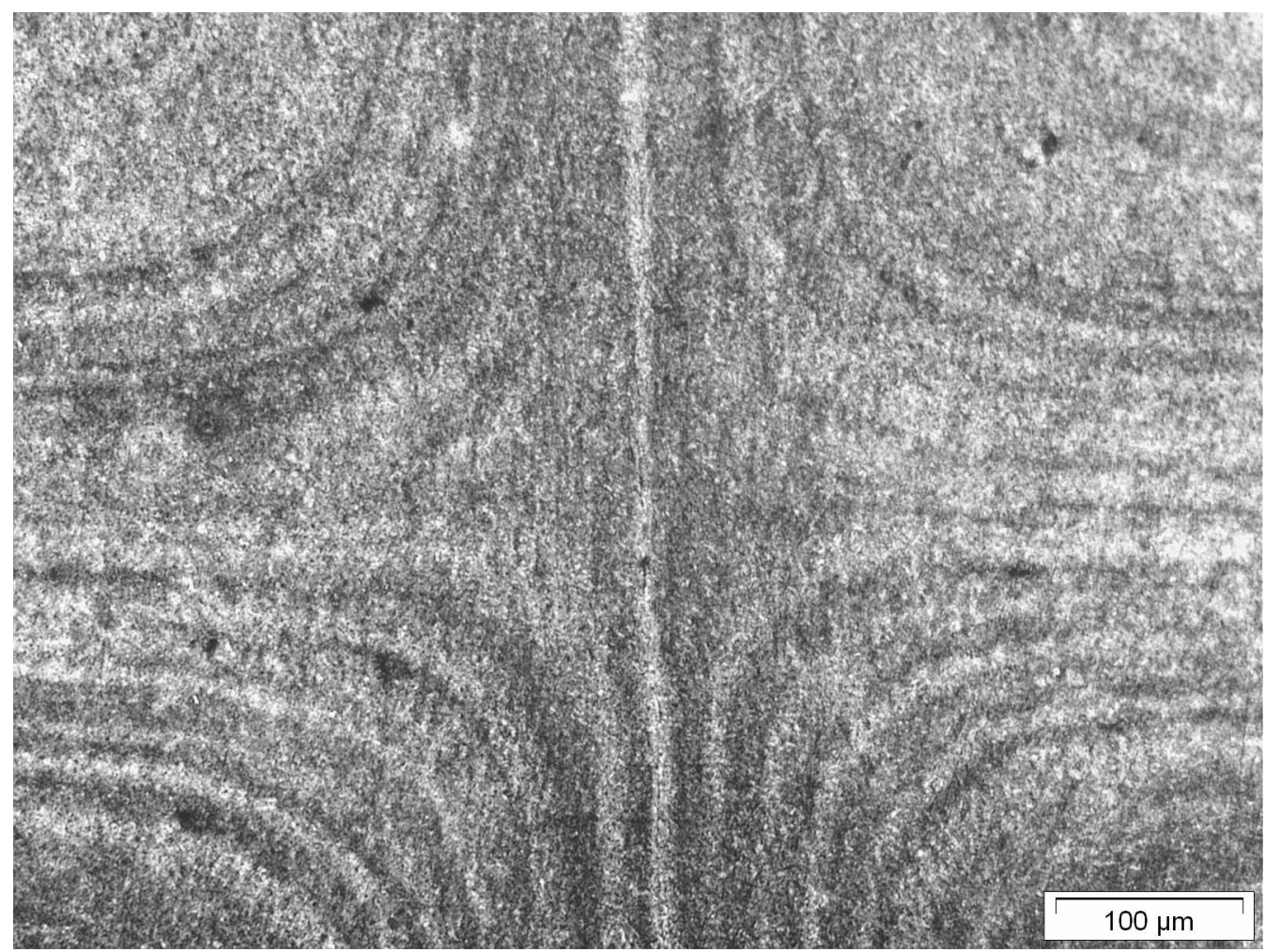

Figura 5.1 Microestrutura transversal à LCS da amostra E1T2 mostrando a linha clara e reta no centro da solda que é a LCS. As regiões à direita e à esquerda desta linha são as zonas afetadas pelo calor. Ataque: Villela. MO. 100X.

Algumas amostras, como por exemplo, as amostras A3T1, A3T2, B3T1 E B3T2, não apresentaram uma LCS clara e bem definida, em contraste com a ZAC. Isto indica que a maior parte do material da LCS foi expelida para fora da junta soldada, devido a corrente de soldagem e a força de recalque mais elevadas destes parâmetros em relação aos parâmetros recomendados. A tabela 5.2 apresenta os valores da perda de material no processo de soldagem. Nota-se na tabela 5.2 que os efeitos dos aumentos da corrente e da força de recalque apresentaram uma perda maior de material. Assim, as amostras A3T1 e A3T2 apresentaram distância final dos mordentes de 2,0 
mm e 1,9 mm, relativas aos c.d.p. A31 e A32 (maior corrente de soldagem), respectivamente, enquanto que as amostras B3T1 e B3T2 apresentaram distância final dos mordentes de 2,0 mm e 2,1 mm, relativas aos c.d.p. B31 e B32 (maior força de recalque), respectivamente. A distância final dos mordentes menor que o valor de $2,2^{ \pm 0,1} \mathrm{~mm}$, conforme tabela 4.5 , indica que mais material fundido e amolecido foi expelido para fora da junta, sob forma de rebarba.

Tabela 5.2 Perda de material no processo de soldagem topo-a-topo por centelhamento das serras de fita bimetálica de $27 \mathrm{~mm}$.

\begin{tabular}{|c|c|c|c|c|c|c|}
\hline $\begin{array}{l}\text { Identif. } \\
\text { da } \\
\text { Amostra }\end{array}$ & $\begin{array}{c}\text { Corrente } \\
\text { Elétrica } \\
\text { (TAP) }\end{array}$ & $\begin{array}{c}\text { Pressão de } \\
\text { Recalque } \\
\text { MPa }\end{array}$ & $\begin{array}{c}\text { Tempo de } \\
\text { Centelhamento } \\
\mathrm{s} \\
\end{array}$ & $\begin{array}{c}\text { Distância Inicial } \\
\text { dos Mordentes } \\
\text { mm }\end{array}$ & $\begin{array}{c}\text { Distância Final } \\
\text { dos Mordentes } \\
\text { mm }\end{array}$ & $\begin{array}{c}\text { Perda de } \\
\text { Material } \\
\\
\mathrm{mm} \\
\end{array}$ \\
\hline A11 & 3 & 0,20 & 1,6 & 9,0 & 2,2 & 6,8 \\
\hline A12 & 3 & 0,20 & 1,6 & 9,0 & 2,1 & 6,9 \\
\hline A 21 & 4 & 0,20 & 1,6 & 9,0 & 2,2 & 6,8 \\
\hline $\mathrm{A} 22$ & 4 & 0,20 & 1,6 & 9,0 & 2,1 & 6,9 \\
\hline A31 & 5 & 0,20 & 1,6 & 9,0 & 2,0 & 7,0 \\
\hline A 32 & 5 & 0,20 & 1,6 & 9,0 & 1,9 & 7,1 \\
\hline B11 & 4 & 0,15 & 1,6 & 9,0 & 2,5 & 6,5 \\
\hline B12 & 4 & 0,15 & 1,6 & 9,0 & 2,4 & 6,6 \\
\hline B31 & 4 & 0,25 & 1,6 & 9,0 & 2,0 & 7,0 \\
\hline B32 & 4 & 0,25 & 1,6 & 9,0 & 2,1 & 6,9 \\
\hline $\mathrm{C} 11$ & 4 & 0,20 & 1,6 & 9,0 & 2,2 & 6,8 \\
\hline $\mathrm{C} 12$ & 4 & 0,20 & 1,6 & 9,0 & 2,1 & 6,9 \\
\hline $\mathrm{C} 31$ & 4 & 0,20 & 1,6 & 9,0 & 2,2 & 6,8 \\
\hline C32 & 4 & 0,20 & 1,6 & 9,0 & 2,2 & 6,8 \\
\hline D11 & 4 & 0,20 & 1,6 & 9,0 & 2,2 & 6,8 \\
\hline D12 & 4 & 0,20 & 1,6 & 9,0 & 2,1 & 6,9 \\
\hline $\mathrm{D} 21$ & 4 & 0,20 & 1,6 & 9,0 & 2,1 & 6,9 \\
\hline D22 & 4 & 0,20 & 1,6 & 9,0 & 2,2 & 6,8 \\
\hline D31 & 4 & 0,20 & 1,6 & 9,0 & 2,1 & 6,9 \\
\hline D32 & 4 & 0,20 & 1,6 & 9,0 & 2,1 & 6,9 \\
\hline E11 & 4 & 0,20 & 1,6 & 9,0 & 2,2 & 6,8 \\
\hline E12 & 4 & 0,20 & 1,6 & 9,0 & 2,1 & 6,9 \\
\hline E21 & 4 & 0,20 & 1,6 & 9,0 & 2,1 & 6,9 \\
\hline E22 & 4 & 0,20 & 1,6 & 9,0 & 2,2 & 6,8 \\
\hline E31 & 4 & 0,20 & 1,6 & 9,0 & 2,2 & 6,8 \\
\hline E32 & 4 & 0,20 & 1,6 & 9,0 & 2,2 & 6,8 \\
\hline
\end{tabular}




\subsubsection{Microestrutura da Região da Solda $(L C S+Z A C)$.}

A microestrutura da região da solda (LCS + ZAC) foi caracterizada por martensita revenida fina em todas as amostras que foram revenidas após a soldagem ${ }^{(61)}$, exceto para as amostras do parâmetro $\mathrm{C} 1$, que não foram revenidas.

A LCS apresentou microestrutura um pouco mais grosseira em relação à microestrutura da ZAC, em função da temperatura ter sido mais elevada na região da interface da solda, onde a resistência elétrica é maior. Isto fez com que os grãos do material na LCS crescessem um pouco mais em relação aos grãos na ZAC. A figura 5.2 ilustra esta característica, que poderá ser melhor observada na figura 5.14, que mostra a seção longitudinal da LCS.

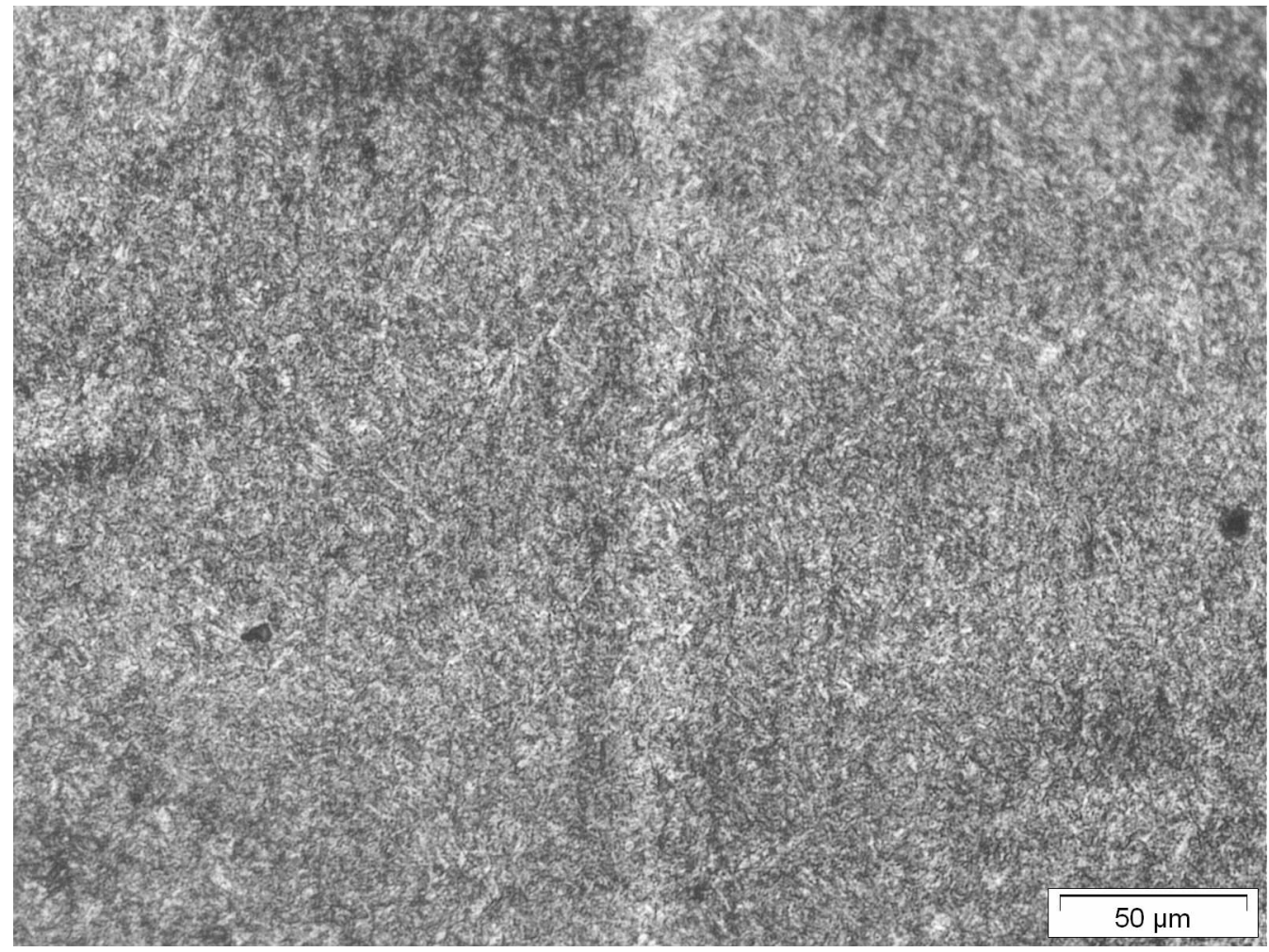

Figura 5.2 Microestrutura transversal à LCS da amostra B1T1 mostrando a LCS ao centro com microestrutura um pouco mais grossa que a microestrutura da ZAC. Ataque: Villela. MO. $200 X$. 
Nas amostras que não foram revenidas após a soldagem, a microestrutura resultante na região da solda foi martensita virgem. A LCS e a ZAC de uma amostra que não foi revenida podem ser observadas na figura 5.3 a seguir. Neste caso, a LCS, com microestrutura mais grosseira que a ZAC, apresenta uma cor mais escura, contrastante com a matriz mais clara da martensita virgem.

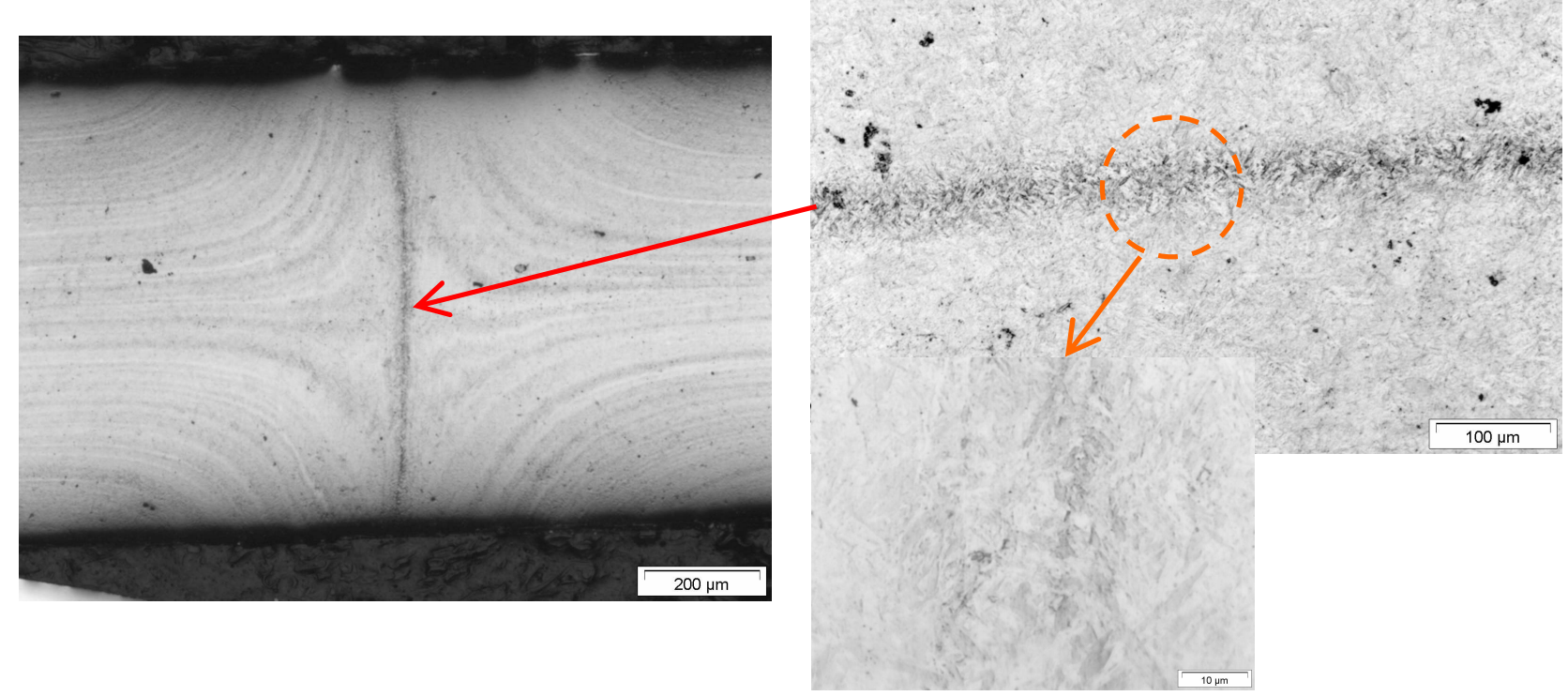

Figura 5.3 Microestrutura transversal à LCS mostrando região da solda da amostra C1T1 que não foi revenida após soldagem, com LCS e ZAC apresentando martensita virgem. A LCS apresenta microestrutura mais grosseira em relação à ZAC. Ataque: Villela. MO. 50X, 100X e $1.000 \mathrm{X}$.

Conforme pode ser observado nas figuras de 5.4 a 5.7, a região da solda apresenta microestrutura martensítica revenida de grãos mais finos, enquanto que o metal de base apresenta microestrutura martensítica revenida de grãos mais grosseiros. Este fato é devido à maior temperatura de austenitização experimentada pelo material D-6a durante a fabricação da serra de fita, em função do aço rápido M42, em relação ao aquecimento gerado durante ao processo de soldagem topo-atopo por centelhamento. 


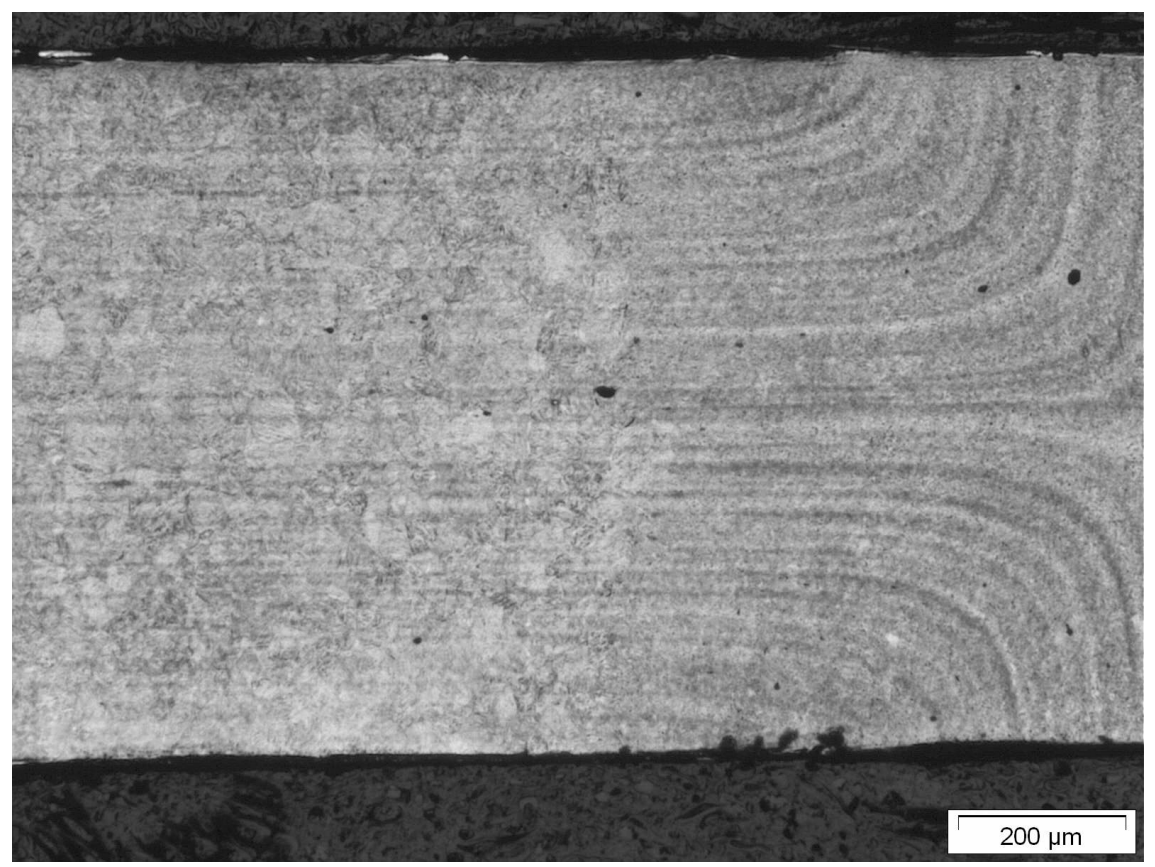

Figura 5.4 Microestrutura transversal à LCS mostrando interface região da solda x metal de base da amostra A1T1. Região da solda à direita apresenta martensita revenida fina e o metal de base (corpo da serra de fita que não foi soldado) à esquerda apresenta martensita revenida mais grosseira. Ataque: Villela. MO. 50X.

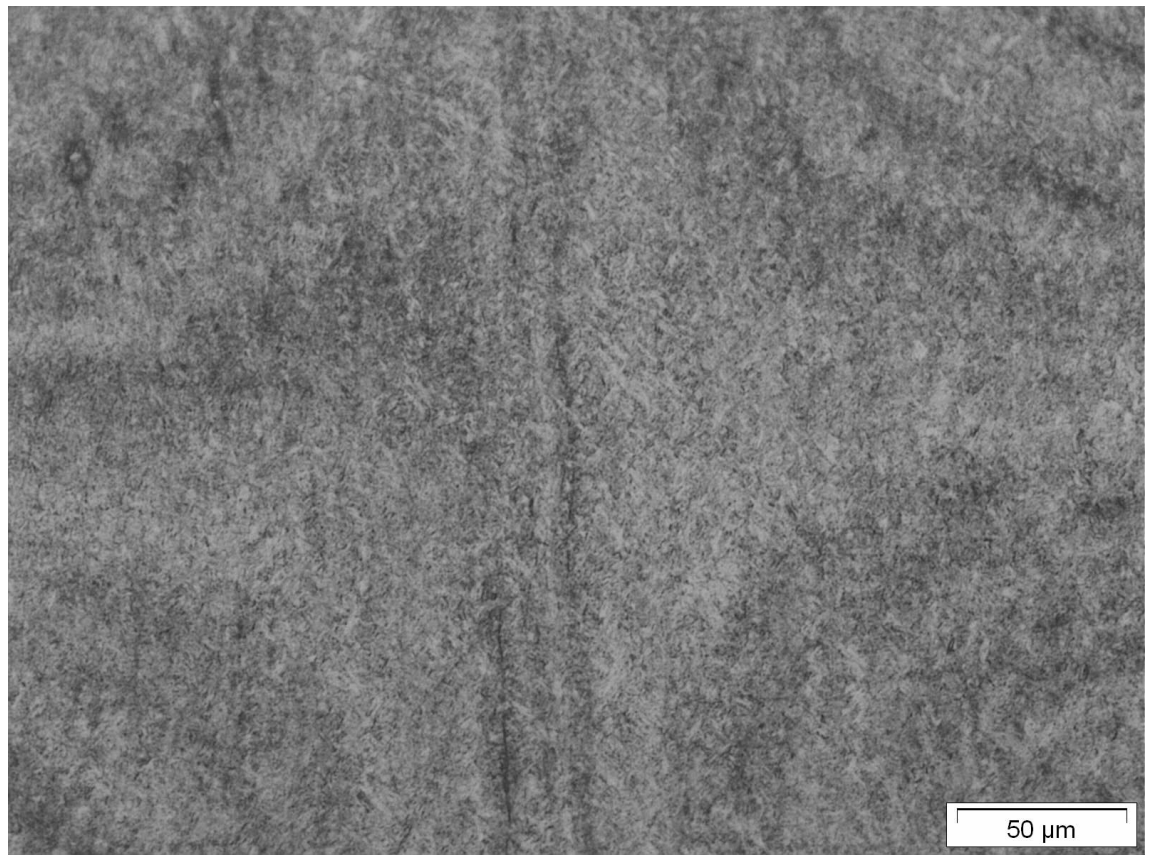

Figura 5.5 Microestrutura transversal à LCS da amostra A1T1 mostrando LCS com martensita revenida mais fina em relação ao metal de base. Ataque: Villela. MO. 200X. 


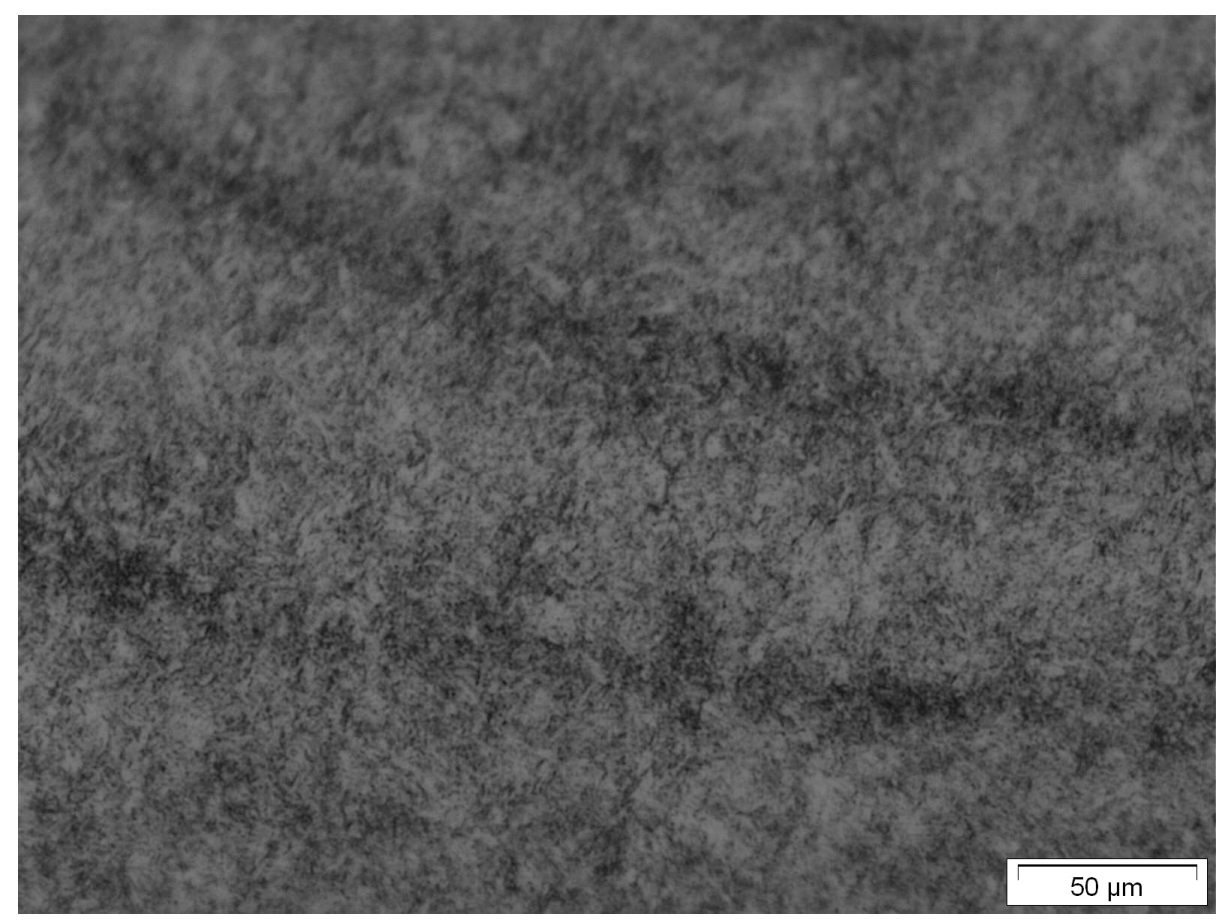

Figura 5.6 Microestrutura transversal à LCS da amostra A1T1 mostrando ZAC com martensita revenida mais fina em relação ao metal de base. Ataque: Villela. MO. 200X.

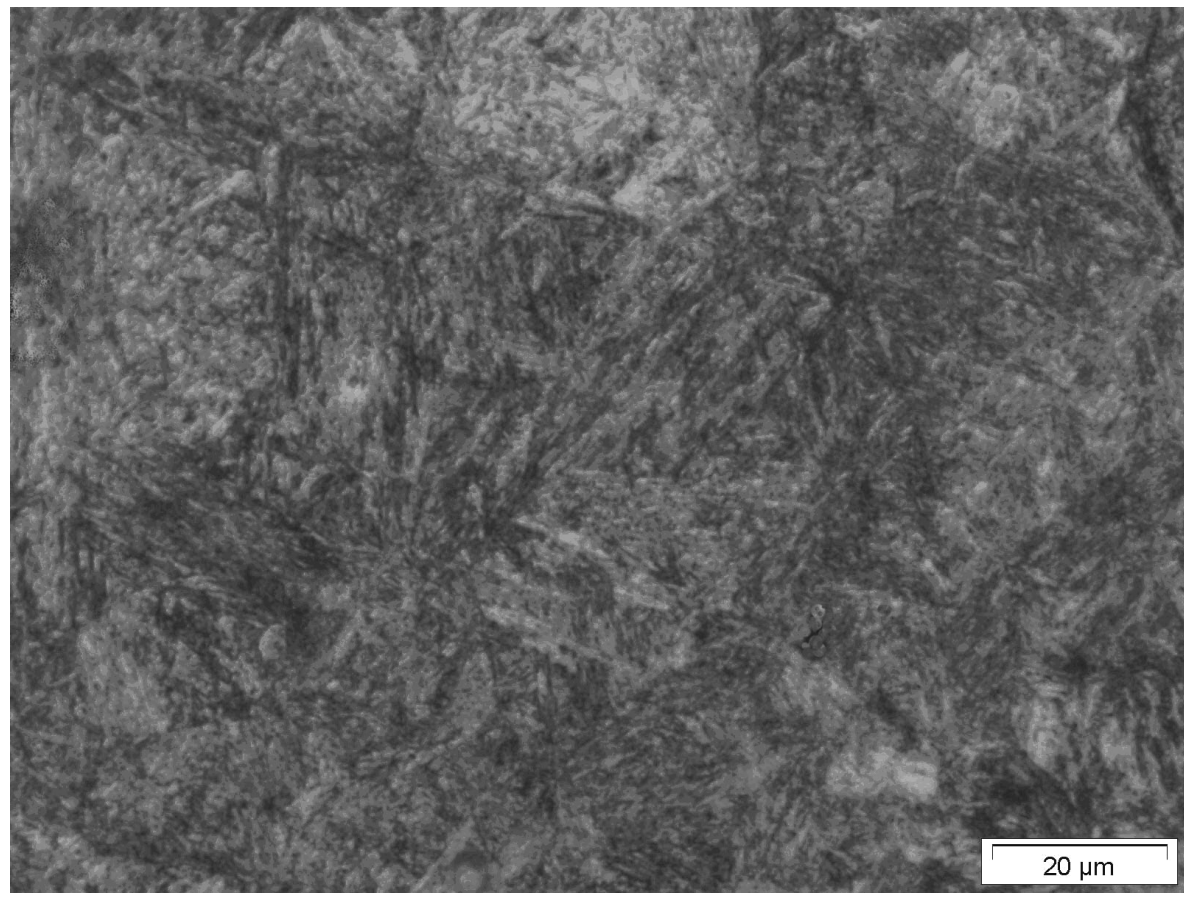

Figura 5.7 Metal de base da serra de fita fora da região da solda. Amostra A1T1 extraída transversalmente à linha central da solda. Microestrutura constituída por martensita revenida mais grosseira em relação à região da solda. Ataque: Villela. MO. Aumento: 500X. 
A figura 5.8 mostra a interface região da solda / metal de base da amostra C1T2 que não foi revenida. A martensita virgem da região da solda (região de cor clara) também possui microestrutura mais fina em relação ao metal de base (região de cor escura), pelos mesmos motivos já explicados anteriormente.

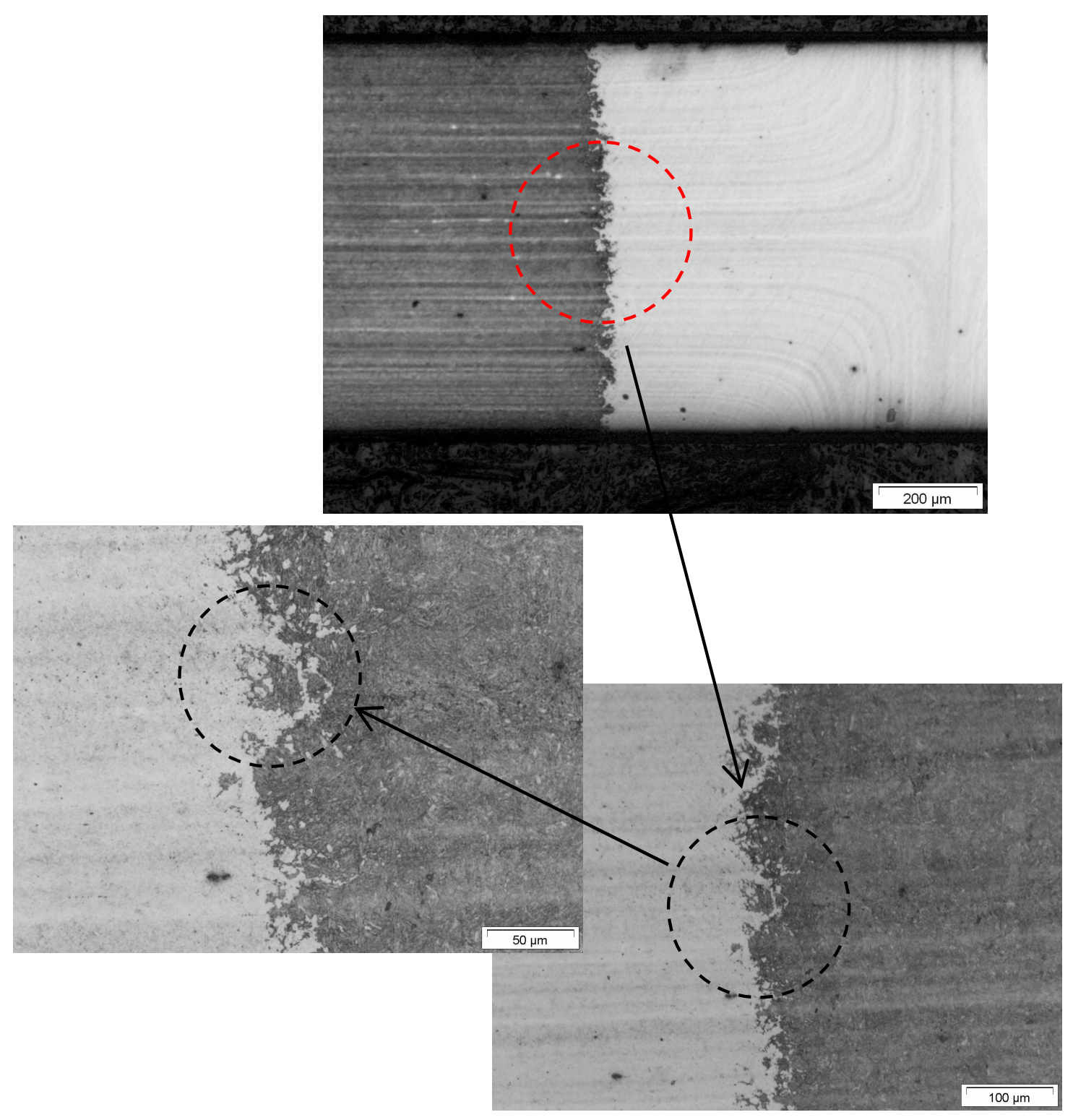

Figura 5.8 Amostra C1T2 extraída transversalmente à linha central da solda., mostrando interface solda/metal de base. A microestrutura de cor clara é a região da solda e a escura é o metal de base (corpo da serra de fita). Ataque: Villela. MO. Aumento: 50X, 100X e 200X. 


\subsubsection{Austenita Retida (AR).}

Algumas amostras, como por exemplo A2T1, D1T1, D2T2, D3T1 e D3T2, apresentaram austenita retida próximo à LCS, conforme pode ser observado na tabela 5.1. A amostra D1T1 foi a que apresentou maior quantidade de austenita retida na microestrutura da seção transversal à LCS, conforme pode ser visto na figura 5.9 a seguir.

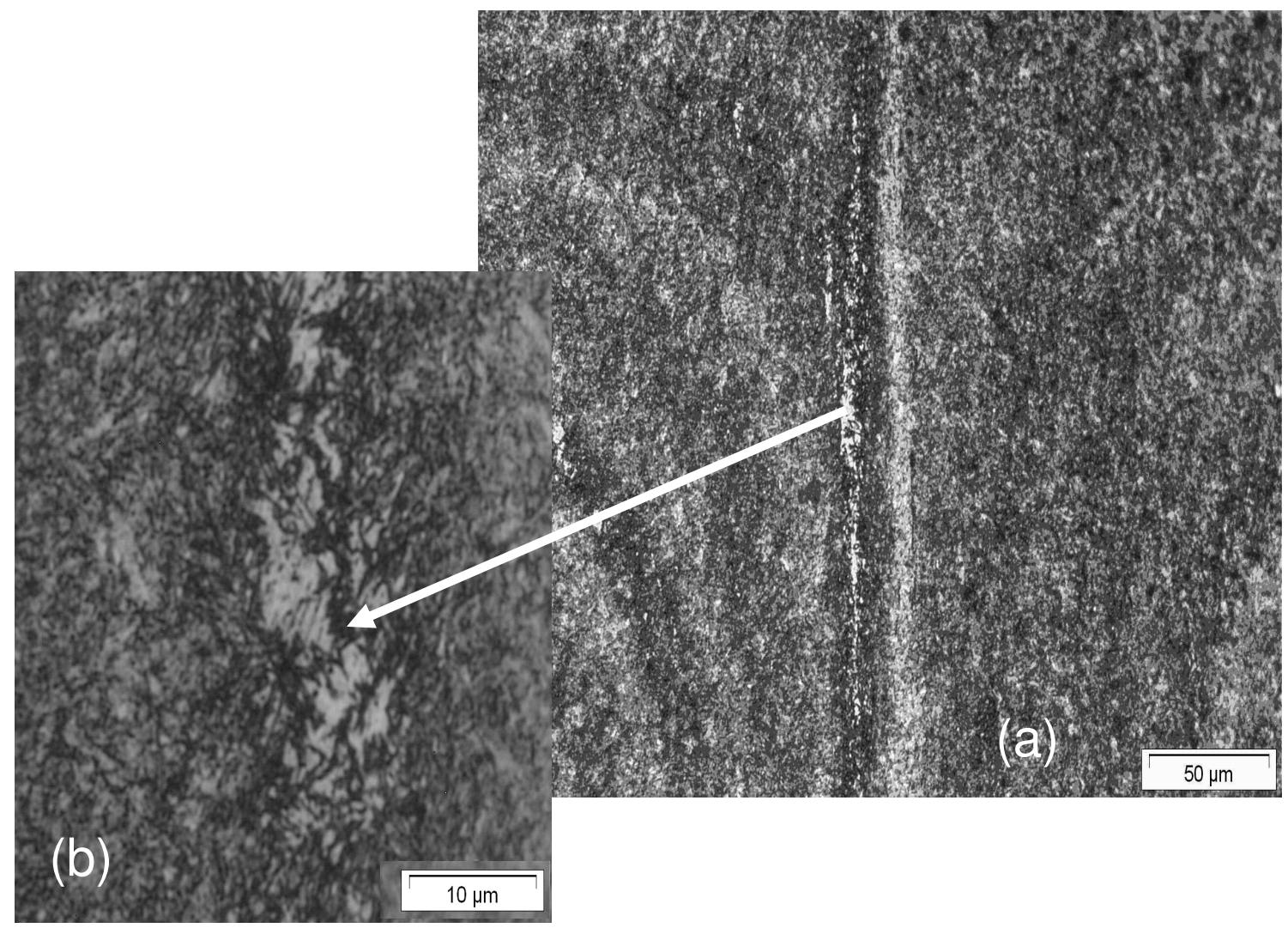

Figura 5.9 Microestrutura transversal à LCS da amostra D1T1 mostrando regiões esbranquiçadas da A.R. à esquerda da LCS. Ataque: Villela. MO. (a) 200X; (b) 1.000X.

Para confirmar a presença da austenita retida foi utilizada a técnica de espectroscopia Mossbauer.

O resultado para a amostra D1T1 está apresentado na figura 5.10. 
(a)

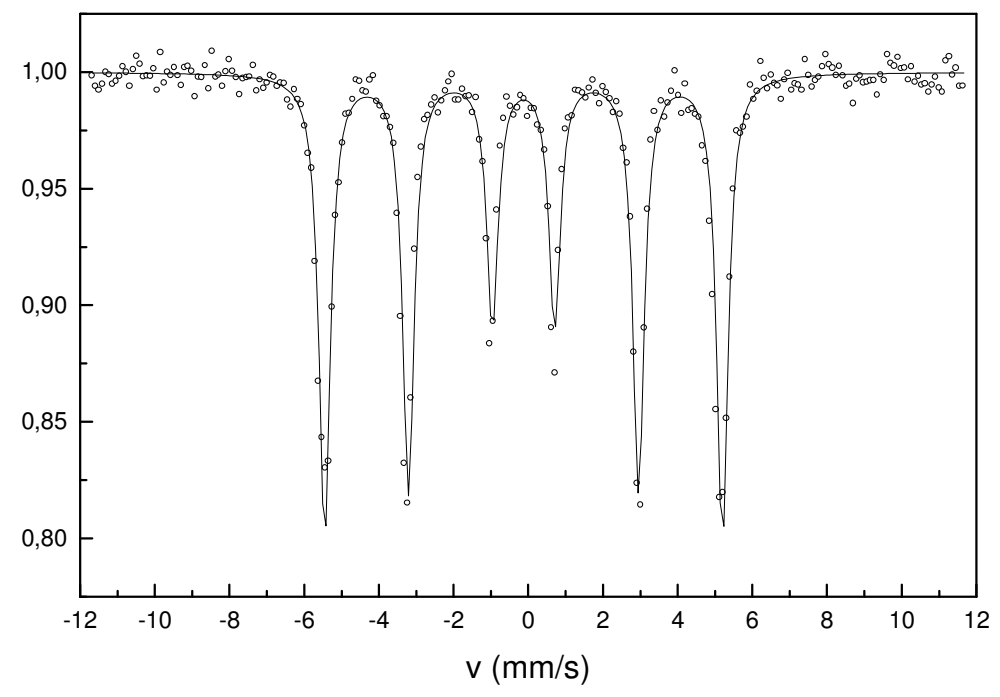

(b)

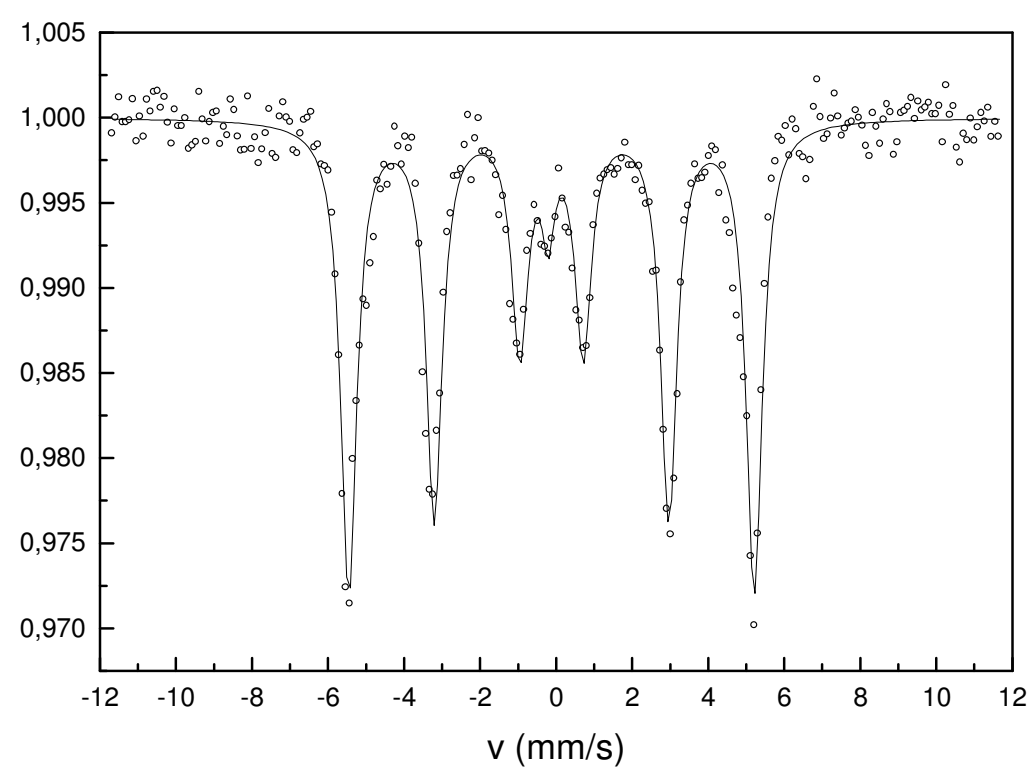

Figura 5.10 Espectroscopia Mosbauer. (a) Espectro de folha fina de ferro puro para calibração.

(b) Espectro da amostra A1T1 mostrando um singleto de austenita no centro do espectro.

Analisando-se a figura 5.10 nota-se um pico central referente a uma fase paramagnética, que é típico da austenita. A razão entre a área deste singleto e o sexteto da ferrita serve para quantificar a austenita retida. $\mathrm{Na}$ amostra em questão o valor da austenita retida foi de $3,1 \%$. 
A austenita retida pode ter surgido devido a um superaquecimento em pontos localizados da microestrutura próxima à LCS, em função do aumento da resistência à passagem da corrente elétrica. Este superaquecimento pode ter sido causado por desgastes ou sujeiras nos mordenteseletrodos de fixação das partes a serem soldadas, e, feito aumentar a temperatura de austenitização do material. Este aumento na temperatura, pode ter causado a dissolução de carbonetos presentes na matriz ou uma mudança de microestrutura no campo ferrita mais austenita acima da temperatura eutetóide. Com isto, a austenita pode ter ficado enriquecida em carbono, abaixando a Ms ainda mais e, consequentemente, não permitindo a sua transformação total em martensita, gerando uma quantidade de austenita retida na temperatura ambiente ${ }^{(61)}$.

\subsubsection{Defeitos na região da solda.}

Nenhuma amostra apresentou defeitos na região da solda, mostrando que óxidos e impurezas presentes nas extremidades das chapas foram todos expulsos pela força de recalque, conforme pode ser verificado na tabela 5.1 e figuras 5.1 a 5.6 anteriores. Mesmo a força de recalque de menor intensidade, parâmetro B1, foi suficiente para expulsar os óxidos e impurezas, juntamente com o material da interface da solda, que forma a rebarba do lado externo da junta. Analogamente, os parâmetros testados não resultaram em porosidades ou trincas na região da solda.

\subsubsection{Linhas de fluxo de material na região da solda.}

As linhas de fluxo provenientes das orientações das fibras do material no processo de laminação das chapas foram deformadas na direção da LCS através da força de recalque. Esta deformação 
resultou em linhas curvas dentro da região da ZAC, conforme pode ser observado nas figuras 5.11 e 5.12 a seguir.

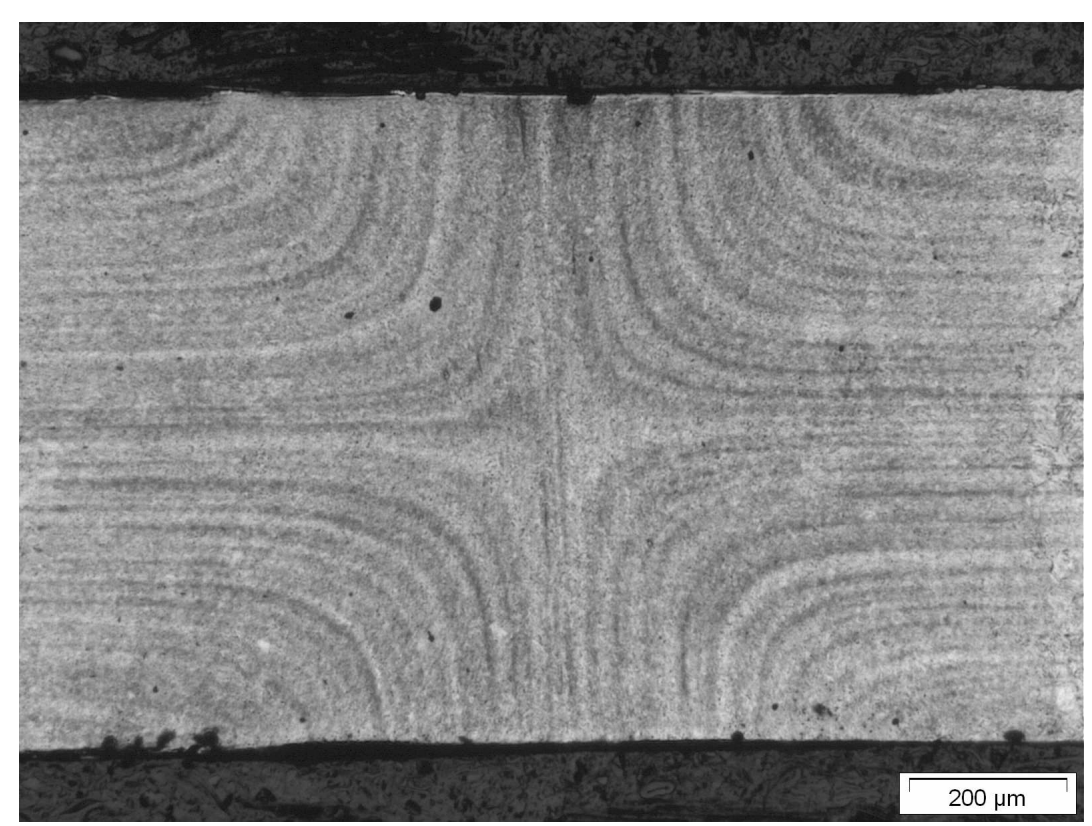

(a)

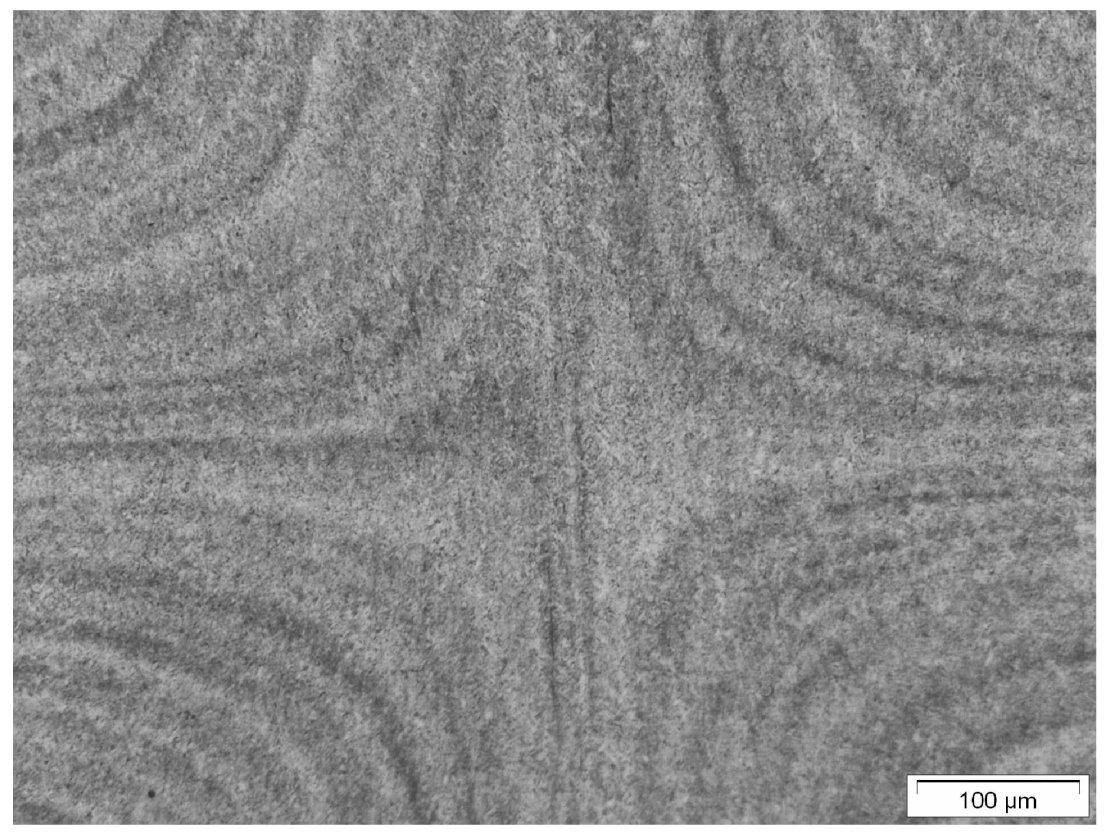

(b)

Figura 5.11 Microestrutura transversal à LCS da amostra A1T1 mostrando as linhas de fluxo do material na ZAC, que foram deformadas pela força de recalque no sentido contrário à LCS. Ataque: Villela. MO. (a)50X; (b)100X. 


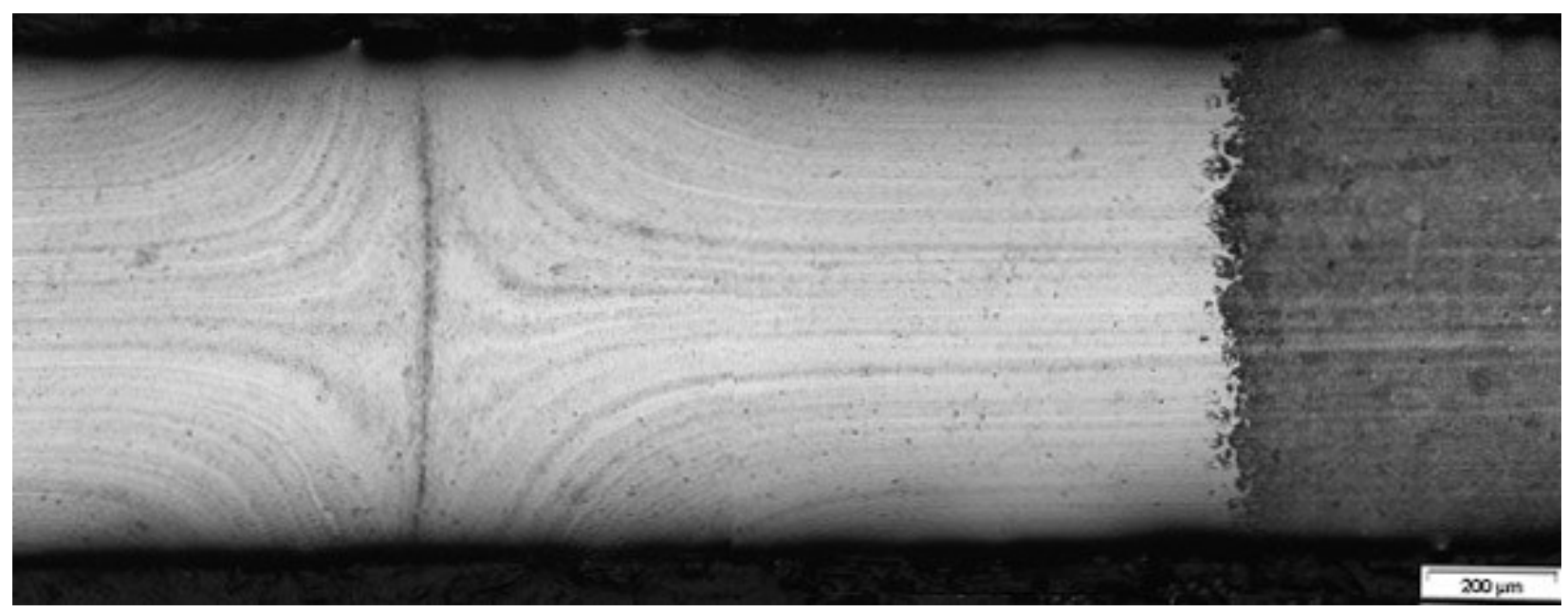

Figura 5.12 Microestrutura transversal à LCS da amostra C1T1 mostrando as linhas de fluxo do material na ZAC, que foram deformadas pela força de recalque no sentido contrário à LCS. Ataque: Villela. MO. 50X.

As linhas curvas claras e escuras na região da ZAC mostram a deformação a quente nas fibras do material provocadas pela ação da força de recalque e do aquecimento localizado e indicam prováveis regiões de segregação de elementos de liga. Os grãos da microestrutura na região da ZAC foram deformados na direção da LCS, gerando o efeito das linhas curvadas. Na região mais distante da linha central da solda não existe curvatura das linhas de fluxo do material, conforme pode ser observado na figura 5.12. Os grãos são paralelos à direção original de laminação das chapas. Este fenômeno está em conformidade com o observado na literatura ${ }^{(33,61)}$.

\subsubsection{Microestrutura da Seção Longitudinal à Linha Central da Solda.}

Analogamente ao verificado no item 5.1.1 para a microestrutura da seção transversal, a microestrutura da junta soldada no sentido longitudinal à LCS foi caracterizada por martensita revenida em todas as amostras que foram revenidas após a soldagem ${ }^{(61)}$, com exceção da amostra 
do parâmetro $\mathrm{C} 1$, que não foi revenida. Neste caso, a microestrutura resultante foi martensita virgem, proveniente do processo de aquecimento do aço D-6a acima da temperatura crítica durante a soldagem, seguido de resfriamento ao ar. Os resultados das análises microestruturais estão relacionados na tabela 5.3.

Tabela 5.3 Análise da Microestrutura na Seção longitudinal à Linha Central da Solda.

\begin{tabular}{|c|c|c|c|c|c|c|c|c|}
\hline \multicolumn{9}{|c|}{ Análise da Microestrutura na Seção Longitudinal à Linha Central da Solda. } \\
\hline \multirow{3}{*}{$\begin{array}{c}\text { Identificação } \\
\text { da } \\
\text { Amostra }\end{array}$} & \multirow{2}{*}{\multicolumn{2}{|c|}{$\begin{array}{c}\text { LCS } \\
\text { Clara e bem definida }\end{array}$}} & \multicolumn{6}{|c|}{$\mathrm{LCS}+\mathrm{ZAC}$} \\
\hline & & & \multicolumn{2}{|c|}{ Martensita Revenida } & \multicolumn{2}{|c|}{ Austenita Retida } & \multicolumn{2}{|c|}{ * Defeitos } \\
\hline & Sim & Não & Sim & Não & Sim & Não & Sim & Não \\
\hline A1L1 & $\mathrm{X}$ & & $\mathrm{X}$ & & & $\mathrm{X}$ & & $\mathrm{X}$ \\
\hline A1L2 & $\mathrm{X}$ & & $\mathrm{X}$ & & $\mathrm{X}$ & & & $\mathrm{X}$ \\
\hline A2L1 & $\mathrm{X}$ & & $\mathrm{X}$ & & $\mathrm{X}$ & & & $\mathrm{X}$ \\
\hline A2L2 & $\mathrm{X}$ & & $X$ & & $X$ & & & $X$ \\
\hline A3L1 & & $X$ & $X$ & & & $X$ & & $X$ \\
\hline A3L2 & & $X$ & $X$ & & & $X$ & & $X$ \\
\hline B1L1 & $X$ & & $X$ & & & $X$ & & $X$ \\
\hline B1L2 & $X$ & & $X$ & & & $X$ & & $\mathrm{X}$ \\
\hline B3L1 & & $X$ & $X$ & & & $X$ & & $\mathrm{X}$ \\
\hline B3L2 & & $X$ & $X$ & & & $X$ & & $\mathrm{X}$ \\
\hline C1L1 & & $X$ & & $X$ & & $X$ & & $X$ \\
\hline C1L2 & & $X$ & & $X$ & & $X$ & & $X$ \\
\hline C3L1 & $X$ & & $X$ & & $X$ & & & $X$ \\
\hline C3L2 & $X$ & & $X$ & & & $X$ & & $X$ \\
\hline D1L1 & $X$ & & $X$ & & $\mathrm{X}$ & & & $X$ \\
\hline D1L2 & $X$ & & $X$ & & & $X$ & & $X$ \\
\hline D2L1 & $X$ & & $X$ & & $X$ & & & $X$ \\
\hline D2L2 & $X$ & & $X$ & & & $X$ & & $X$ \\
\hline D3L1 & $X$ & & $X$ & & & $X$ & & $X$ \\
\hline D3L2 & $X$ & & $X$ & & & $X$ & & $X$ \\
\hline E1L1 & $X$ & & $X$ & & & $X$ & & $X$ \\
\hline E1L2 & $X$ & & $X$ & & & $X$ & & $X$ \\
\hline E2L1 & $X$ & & $X$ & & & $X$ & & $X$ \\
\hline E2L2 & $X$ & & $X$ & & & $X$ & & $X$ \\
\hline E3L1 & $X$ & & $X$ & & $X$ & & & $X$ \\
\hline E3L2 & $X$ & & $X$ & & $\mathrm{X}$ & $X$ & & $X$ \\
\hline
\end{tabular}

* Óxidos, porosidades, trincas, etc. 


\subsubsection{Linha Central da Solda.}

Igualmente ao verificado nas amostras transversais à LCS, a maioria das amostras da seção longitudinal à LCS apresentou uma linha fina, clara, reta e bem definida no centro da solda das duas extremidades da serra de fita, em contraste com a ZAC. Esta linha é a interface da solda, ou seja, onde ocorreu a fusão das duas extremidades do material, e pode ser visualizada na figura 5.13.

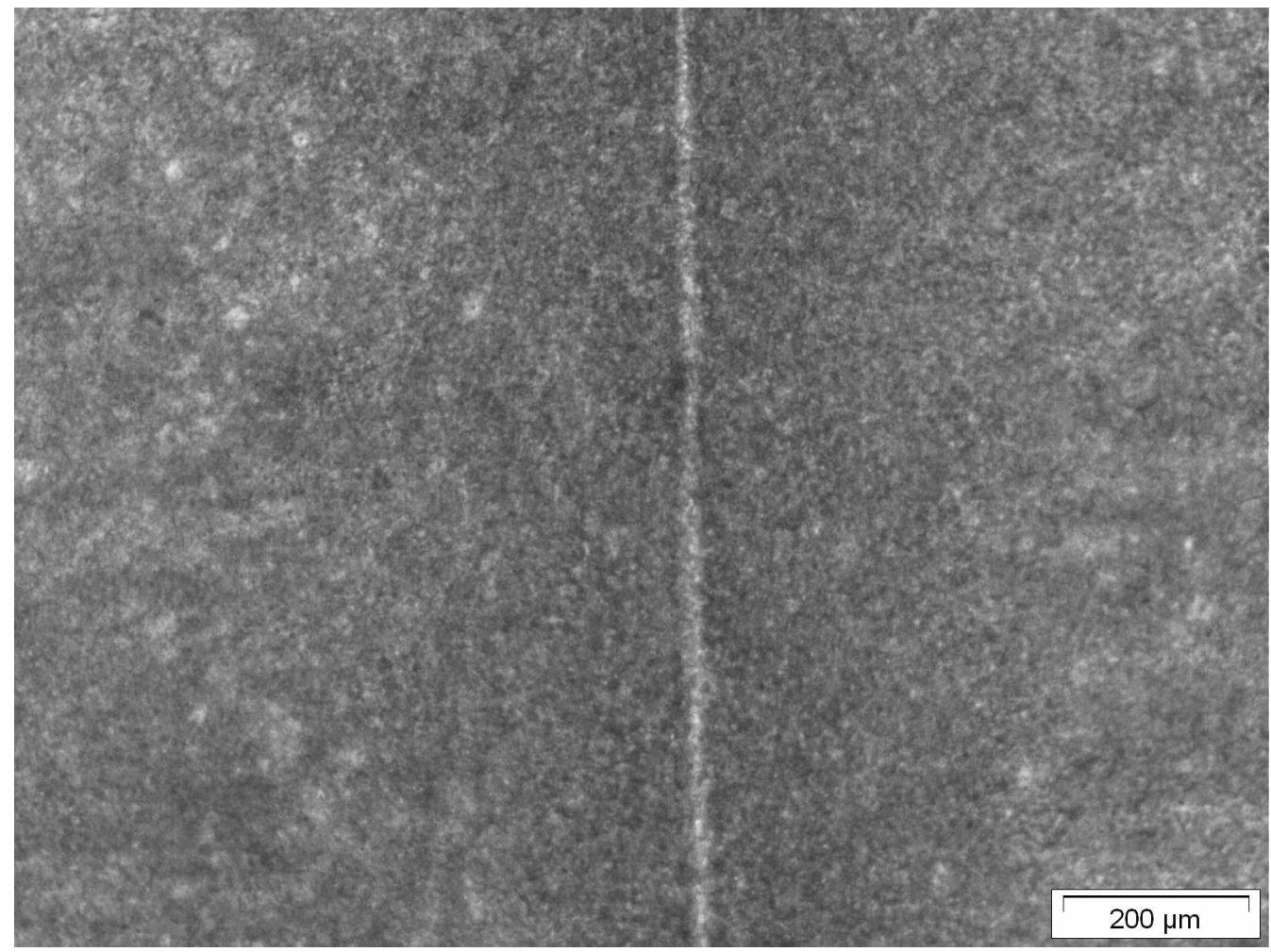

Figura 5.13 Microestrutura longitudinal à LCS da amostra E2L1 mostrando a linha clara e reta no centro da solda que é a LCS. As regiões à direita e à esquerda desta linha são as zonas afetadas pelo calor. A microestrutura mais grosseira à direita da ZAC é o metal de base. Ataque: Villela. MO. 50X. 
Algumas amostras, como por exemplo, as amostras A3L1, A3L2, B3L1 e B3L2 (figura 5.19) não apresentaram uma LCS clara e bem definida, em contraste com a ZAC. Isto indica que uma parte maior do material da LCS foi expelida para fora da junta soldada pela força de recalque. Conforme pode ser observado na tabela 5.2, as amostras A3L1 e A3L2 apresentaram distância final dos mordentes de 2,0 $\mathrm{mm}$ e $1,9 \mathrm{~mm}$, relativas aos corpos de provas A31 e A32, respectivamente, enquanto que as amostras B3L1 e B3L2 apresentaram distância final dos mordentes de 2,0 $\mathrm{mm}$ e 2,1 mm, relativas aos corpos de prova B31 e B32, respectivamente. A distância final dos mordentes menor que o valor de $2,2^{ \pm 0,1} \mathrm{~mm}$, conforme tabela 4.5 , indica que mais material fundido foi expelido para fora da junta sob forma de rebarba.

Nas amostras C1L1 e C1L2 não foi possível uma perfeita visualização da LCS, provavelmente devido à cor clara da martensita virgem da região da solda não ter proporcionado um bom contraste ao ataque químico, contrariamente ao observado para as amostras C1T1 e C1T2.

\subsubsection{Microestrutura da região da solda.}

A microestrutura da região da solda (LCS + ZAC) foi caracterizada por martensita revenida fina em todas as amostras que foram revenidas após a soldagem ${ }^{(61)}$, exceto para as amostras do parâmetro $\mathrm{C} 1$, que não foram revenidas.

A LCS apresentou microestrutura um pouco mais grosseira em relação à microestrutura da ZAC, em função da temperatura ter sido mais elevada na região da interface da solda, onde a resistência elétrica é maior. Esta característica é mostrada na figura 5.14 a seguir. 


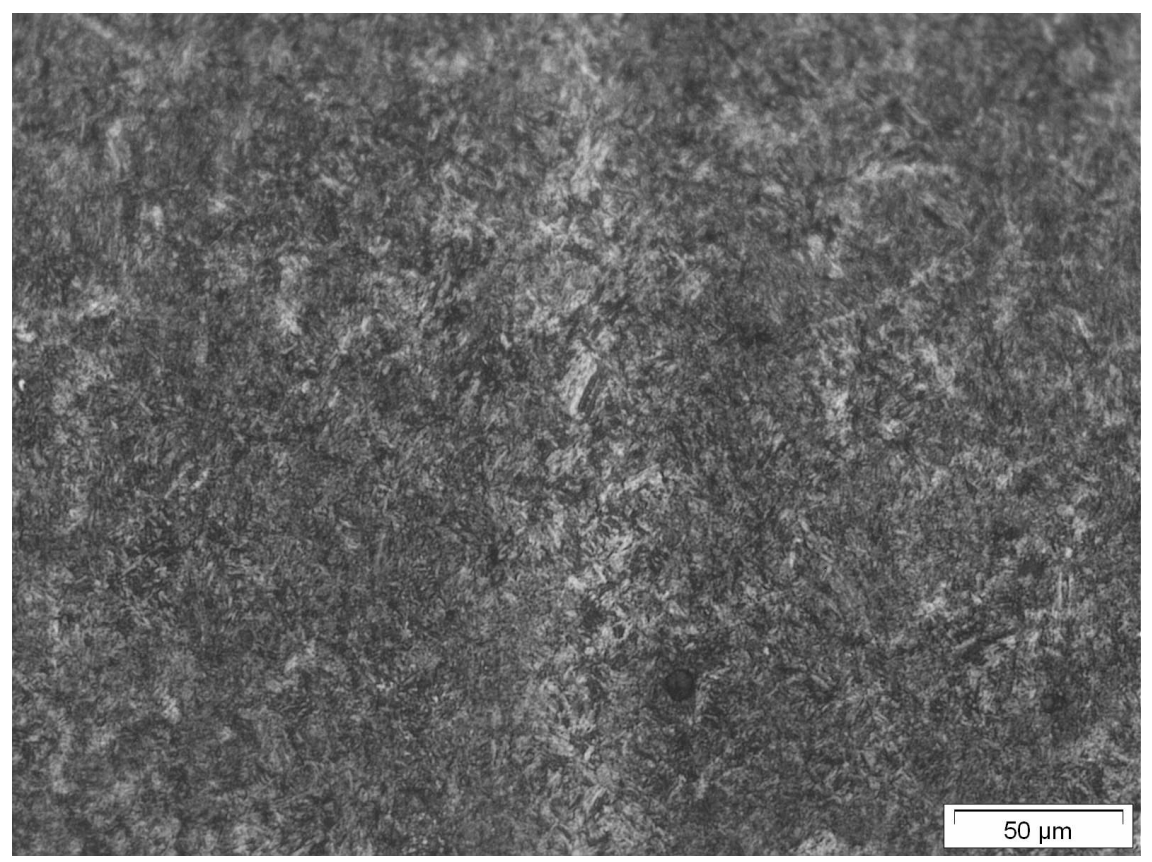

Figura 5.14 Microestrutura longitudinal à LCS da amostra A3L1 mostrando a LCS ao centro com microestrutura um pouco mais grossa que a da ZAC. Ataque: Villela. MO. 200X.

As figuras de 5.15 a 5.17 mostram as diferenças das microestruturas da região da solda mais fina em relação a do metal de base mais grosseira, conforme já explicado no item 5.1.1.2.

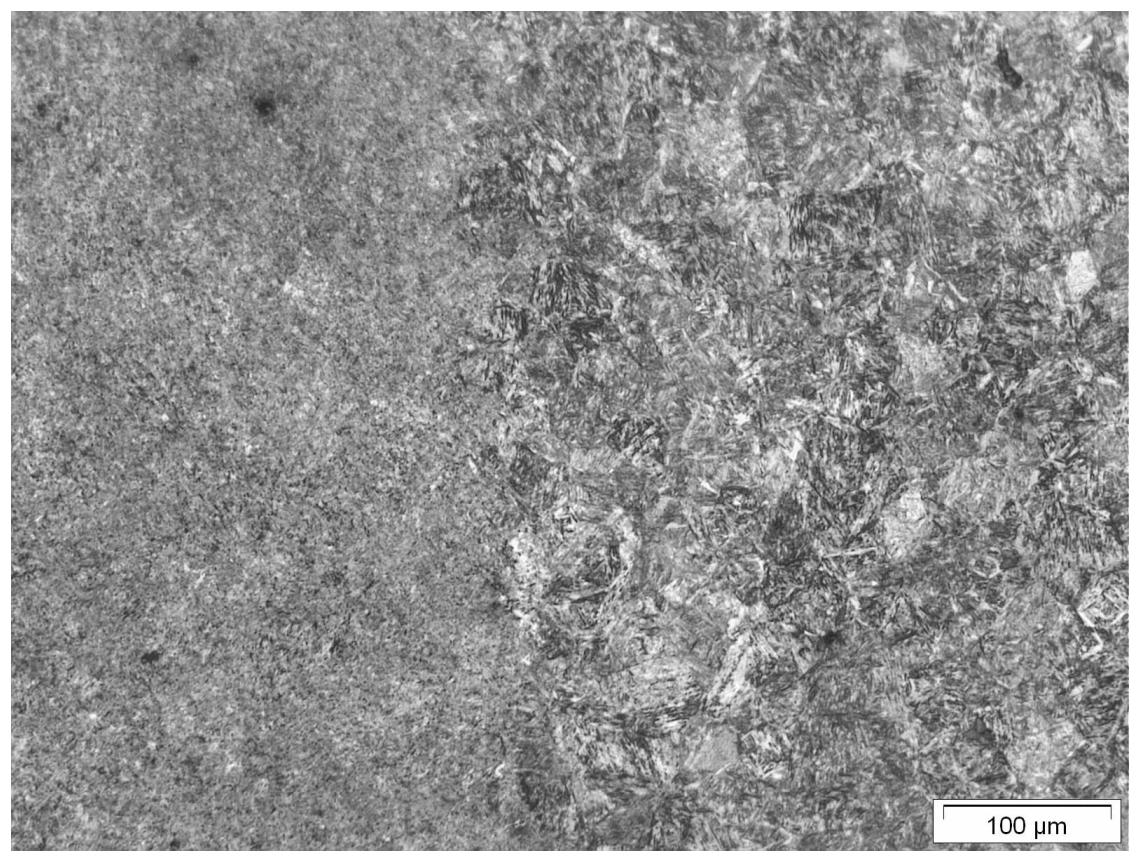

Figura 5.15 Microestrutura longitudinal à LCS da amostra A2L2 mostrando ZAC a esquerda com martensita revenida mais fina em relação a do metal de base. Ataque: Villela. MO. 100X. 


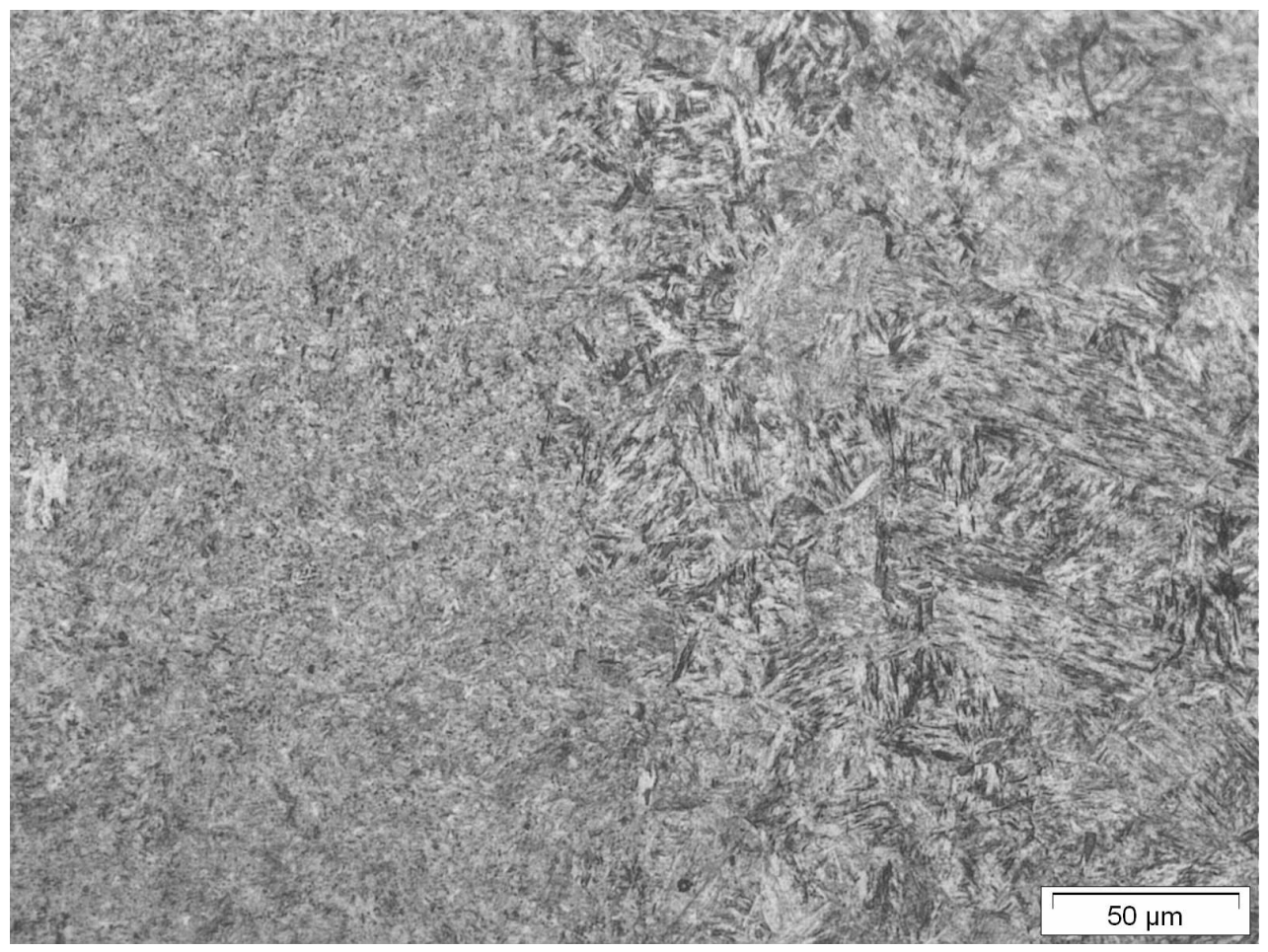

Figura 5.16 Microestrutura longitudinal à LCS da amostra A3L2 mostrando ZAC a esquerda com martensita revenida mais fina em relação a do metal de base. Ataque: Villela. MO. 200X.

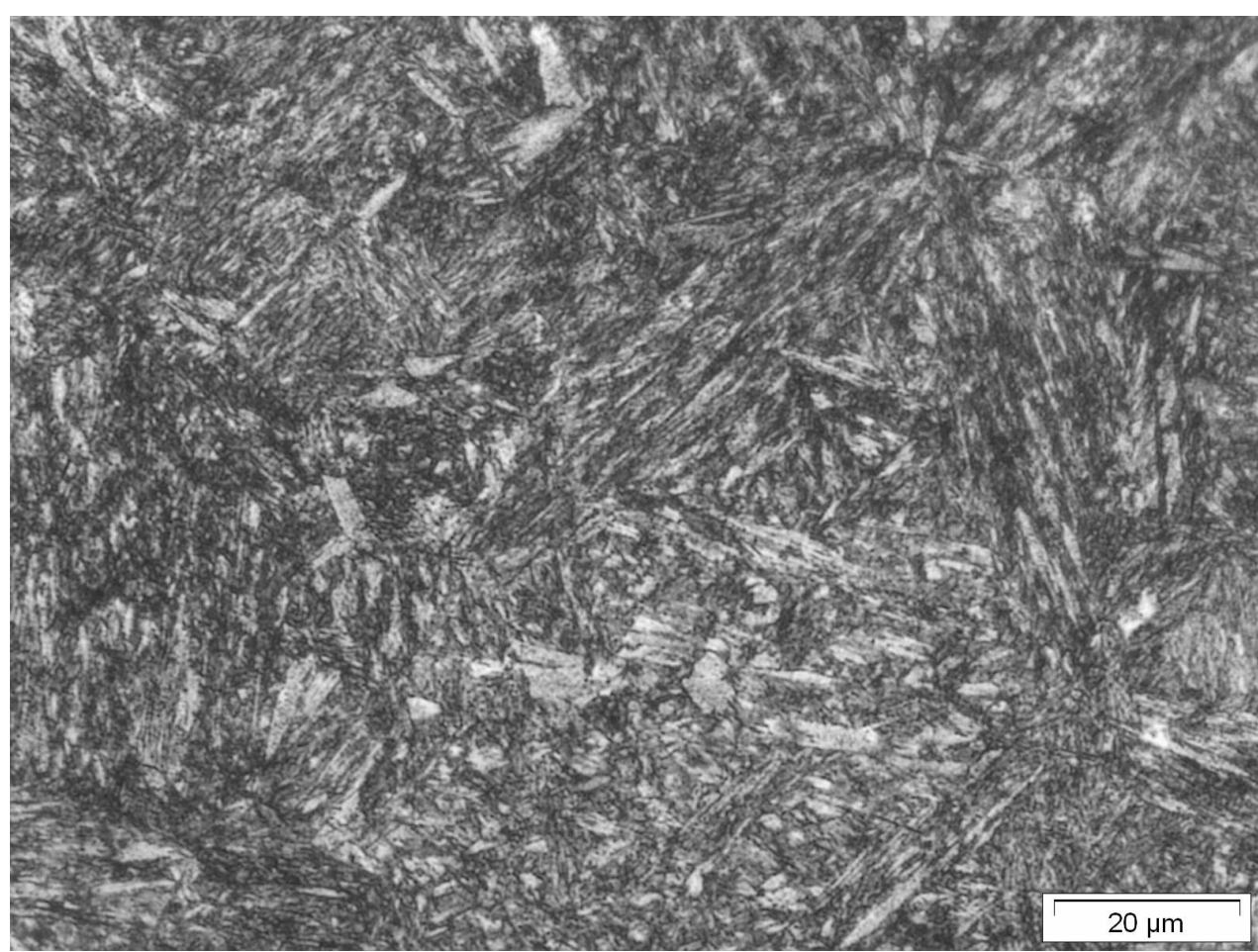

Figura 5.17 Microestrutura longitudinal à LCS da amostra A1L1 mostrando metal de base com martensita revenida mais grosseira em relação à região da solda. Ataque: Villela. MO. 500X. 
Analogamente ao exposto no item 5.1.1.2 e figuras 5.3 e 5.8, as amostras C1L1 e C1L2 foram caracterizadas por martensita virgem, uma vez que estas amostras não foram revenidas após soldagem, conforme tabela "Planejamento dos corpos de prova para ensaios de soldagem em serras de fita bimetálica $27 \mathrm{~mm} "$ do anexo 01 .

\subsubsection{Austenita Retida.}

Algumas amostras, como por exemplo A1L2, A2L1, A2L2, C3L1, D1L1, D2L1, E3L1 e E3L2, apresentaram austenita retida próximo à LCS, conforme pode ser observado na tabela 5.3. Todas as amostras citadas neste item apresentaram, aproximadamente, a mesma quantidade de austenita retida, assim como sua localização foi observada sempre próxima à LCS.

A figura 5.18 mostra a presença de austenita retida nas amostras D1L1 e A1L2, cujos motivos de sua formação já foram descritos no item 5.1.1.3. 


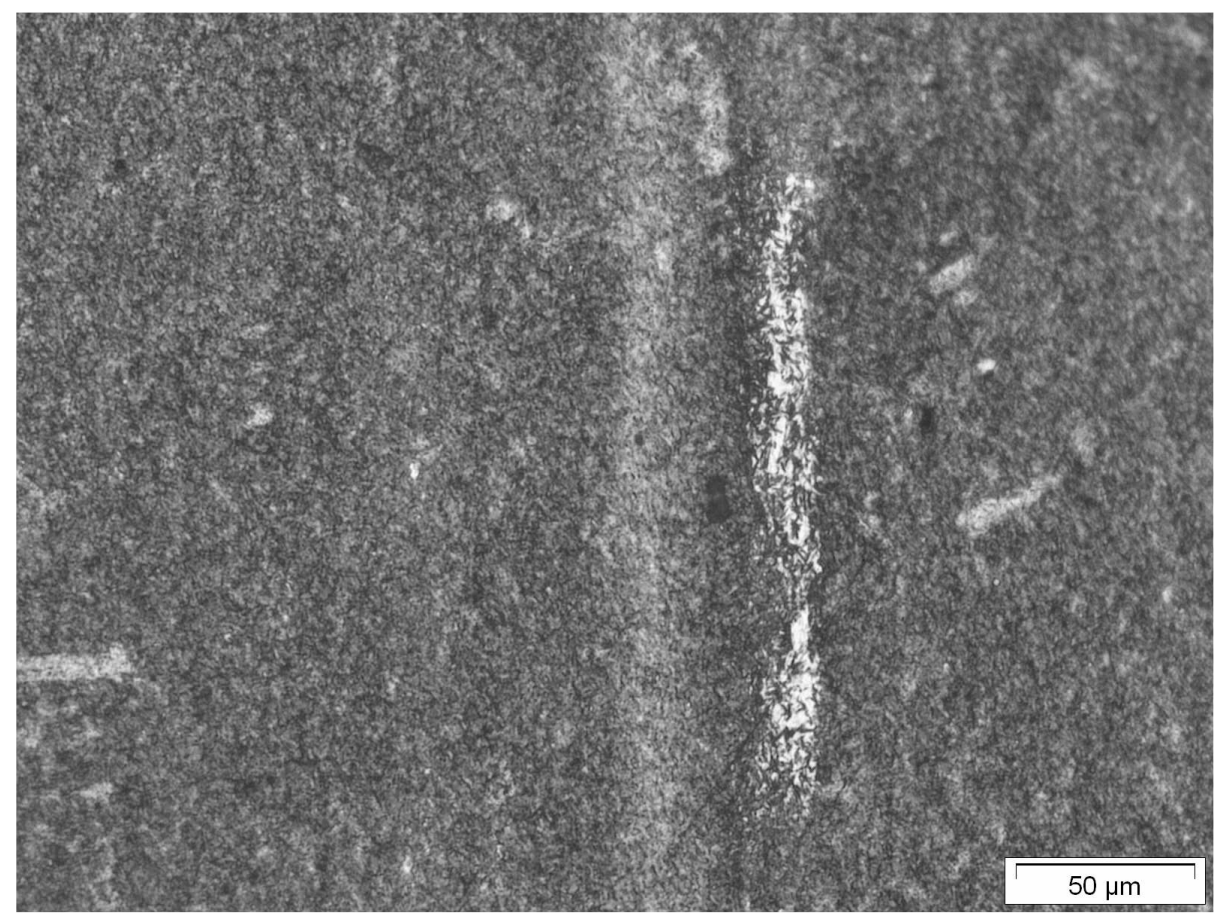

(a)

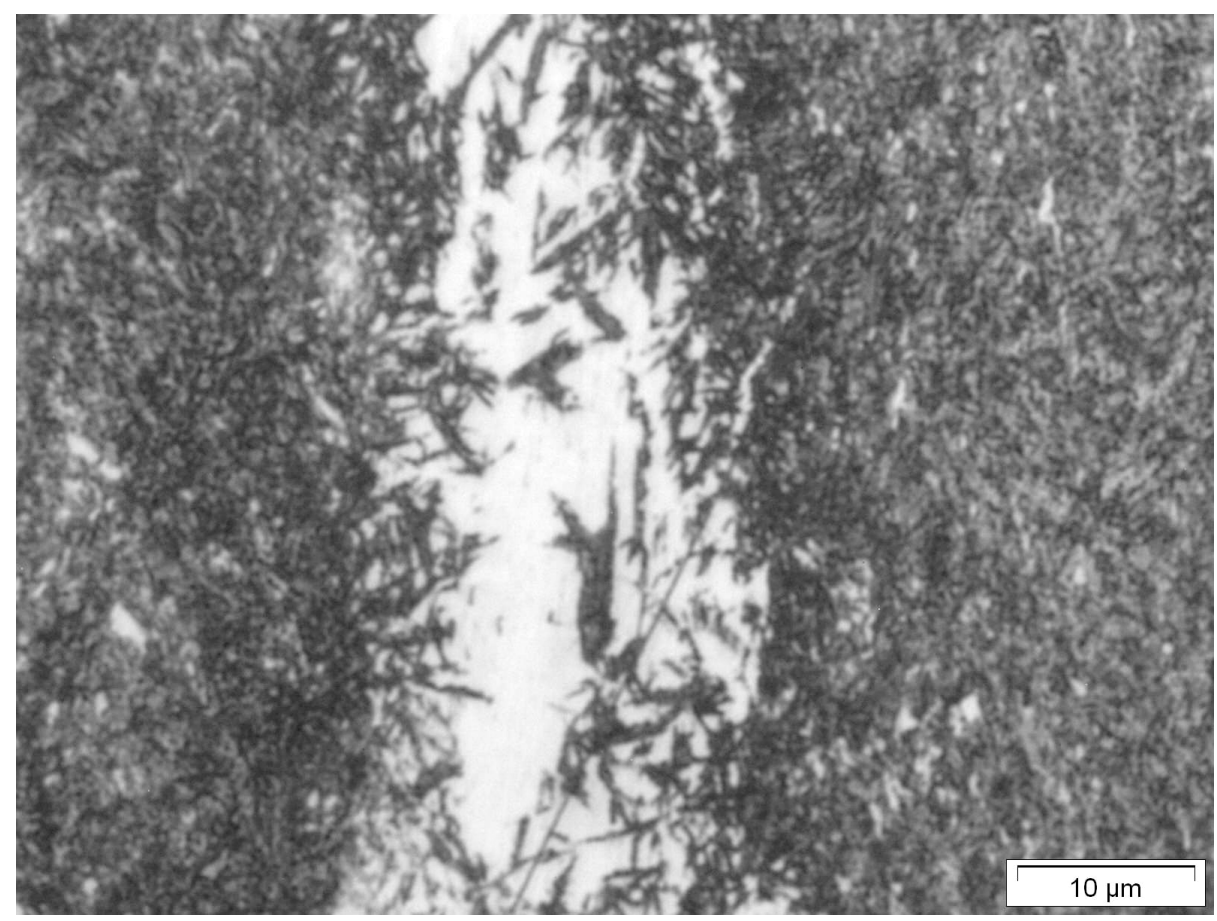

(b)

Figura 5.18 Microestrutura longitudinal à LCS mostrando regiões esbranquiçadas da austenita retida próximo à LCS. Ataque: Villela. MO. (a) Amostra D1L1, 200X; (b) Amostra A1L2, $1.000 \mathrm{X}$. 


\subsubsection{Defeitos na região da solda.}

Analogamente ao já descrito no item 5.1.1.4, nenhuma amostra apresentou defeito na região da solda. A figura 5.19 mostra a microestrutura da amostra B3L2 isenta de óxidos, impurezas, porosidades ou trincas na região da solda. Observa-se ao centro da amostra a LCS com menor contraste com a ZAC, devido a força de recalque de maior intensidade do parâmetro B3 ter expulsado mais material para fora da junta soldada.

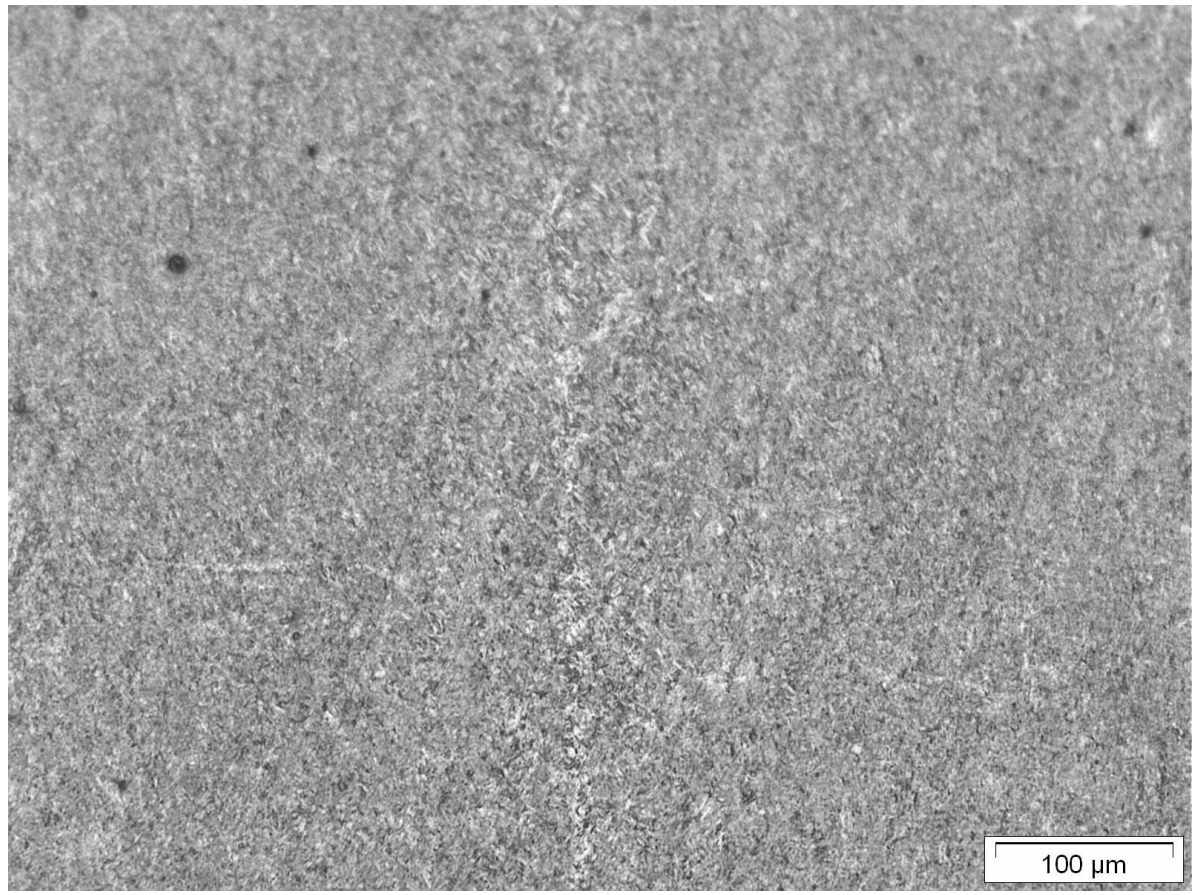

Figura 5.19 Microestrutura longitudinal à LCS mostrando região da solda isenta de defeitos. Amostra B3L2. Ataque: Villela. MO. 100X.

\subsubsection{Microestrutura da Ponta dos Dentes.}

Conforme já visto anteriormente no item 2.1.6, os dentes em aço rápido M42 não são soldados no processo de junção topo-a-topo das extremidades das serras de fita bimetálica, porém, recebem 
influência das altas temperaturas geradas durante este processo. Os resultados das análises microestruturais da ponta dos dentes, pertencentes à região onde foi executada a soldagem, estão relacionados na tabela 5.4. Adicionalmente, foi verificada também a microestrutura de duas amostras, cujos dentes foram retirados de uma região da serra de fita que não foi soldada (amostras F1D1 e F1D2), para fins de comparação com as amostras das regiões das áreas soldadas.

Tabela 5.4 Análise da Microestrutura na Ponta dos Dentes da Serra de Fita Bimetálica 27mm.

\begin{tabular}{|c|c|c|c|c|c|c|c|c|}
\hline \multirow{4}{*}{$\begin{array}{c}\text { Identificação } \\
\text { da } \\
\text { Amostra }\end{array}$} & \multicolumn{8}{|c|}{ Análise da Microestrutura na Ponta dos Dentes da Serra de Fita Bimetálica. } \\
\hline & \multicolumn{4}{|c|}{ Carbonetos } & \multicolumn{4}{|c|}{ Matriz } \\
\hline & \multicolumn{2}{|c|}{ Globulares } & \multicolumn{2}{|c|}{ Bem distribuídos } & \multicolumn{2}{|c|}{ Martensita Revenida } & \multicolumn{2}{|c|}{ Austenita Retida } \\
\hline & Sim & Não & Sim & Não & Sim & Não & Sim & Não \\
\hline A1D1 & $\mathrm{X}$ & & $\mathrm{X}$ & & $\mathrm{X}$ & & & $\mathrm{X}$ \\
\hline A1D2 & $\mathrm{X}$ & & $\mathrm{X}$ & & $\mathrm{X}$ & & & $\mathrm{X}$ \\
\hline A2D1 & $\mathrm{X}$ & & $\mathrm{X}$ & & $\mathrm{X}$ & & & $\mathrm{X}$ \\
\hline $\mathrm{A} 2 \mathrm{D} 2$ & $X$ & & $X$ & & $X$ & & & $X$ \\
\hline A3D1 & $X$ & & $X$ & & $X$ & & & $X$ \\
\hline A3D2 & $X$ & & $\mathrm{X}$ & & $\mathrm{X}$ & & & $X$ \\
\hline C1D1 & $X$ & & $X$ & & $X$ & & & $X$ \\
\hline C1D2 & $X$ & & $X$ & & $X$ & & & $X$ \\
\hline D3D1 & $\mathrm{X}$ & & $X$ & & $X$ & & & $X$ \\
\hline D3D2 & $X$ & & $X$ & & $X$ & & & $X$ \\
\hline F1D1 & $X$ & & $X$ & & $\mathrm{X}$ & & & $X$ \\
\hline F1D2 & $X$ & & $X$ & & $\mathrm{X}$ & & & $X$ \\
\hline
\end{tabular}

Todas as amostras analisadas, conforme tabela 5.4, apresentaram carbonetos globulares e bem distribuídos em matriz martensítica revenida, isenta de austenita retida e de descarbonetação, pois não foi evidenciado presença de ferrita livre na matriz. As figuras 5.20 e 5.21 mostram as microestruturas das amostras A2D2 / F1D2 e A3D1 / F1D2 respectivamente. 


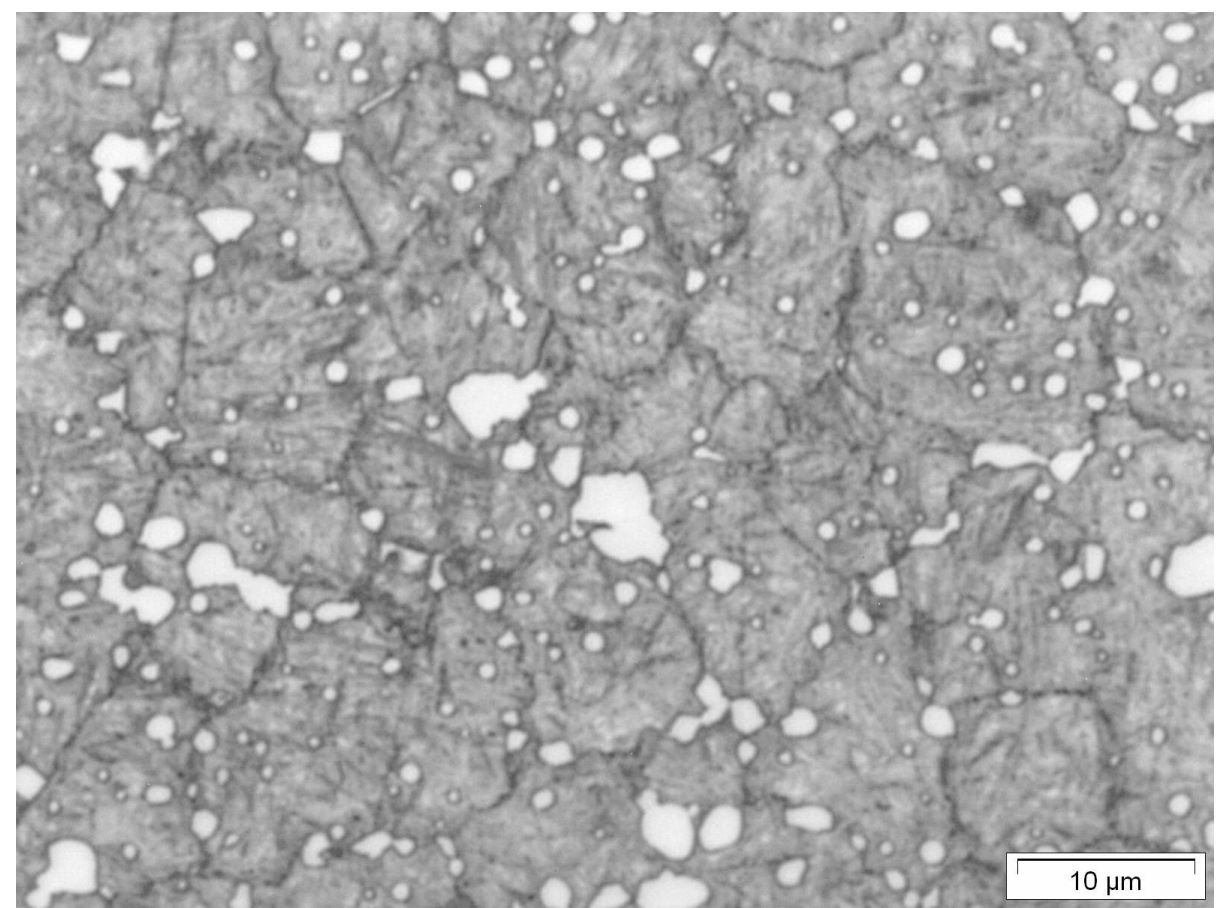

(a)

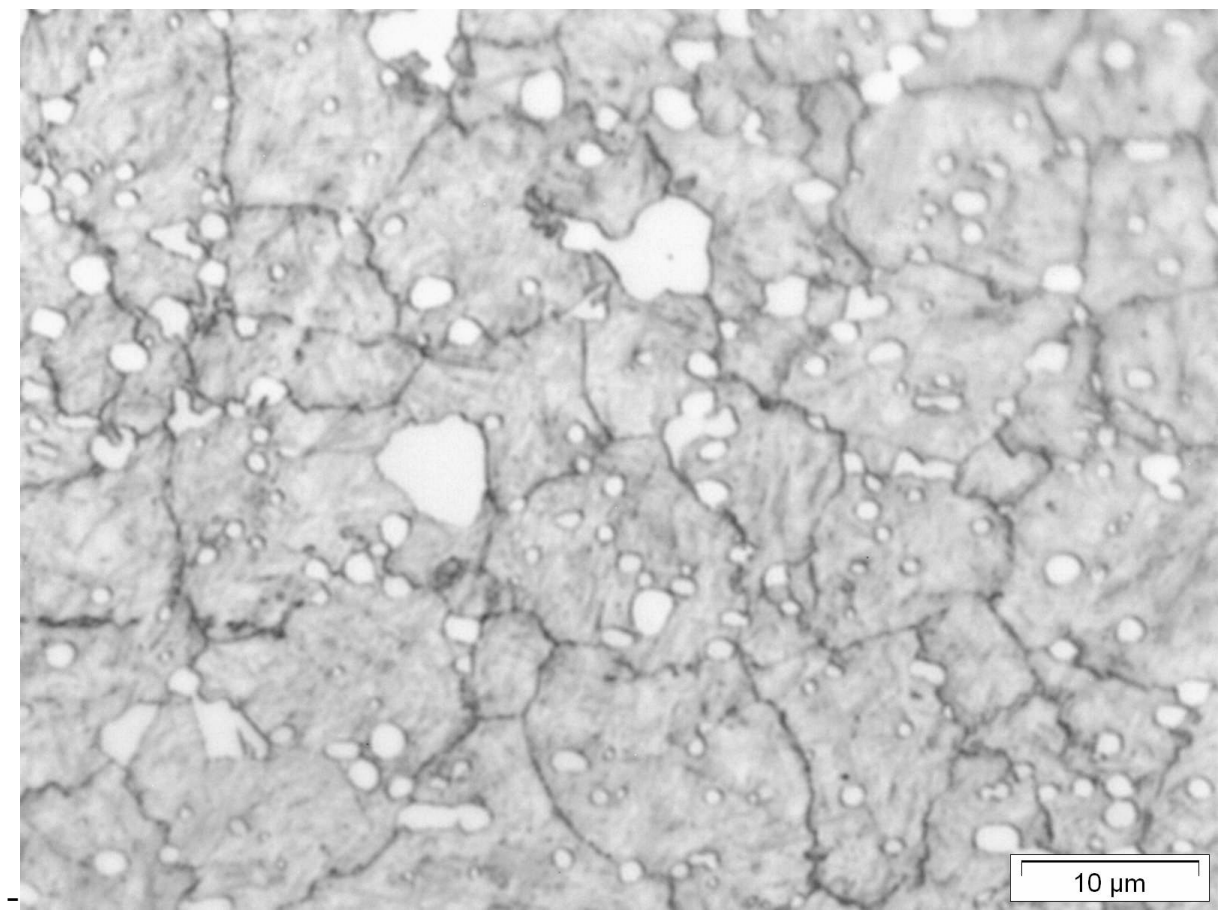

(b)

Figura 5.20 Microestrutura da ponta do dente de aço rápido M42 mostrando carbonetos globulares e bem distribuídos em matriz martensítica revenida isenta de austenita retida e de descarbonetação. Ataque: Villela - 7s. MO. Aumento 1.000X. (a) Amostra A2D2; (b) Amostra F1D2. 


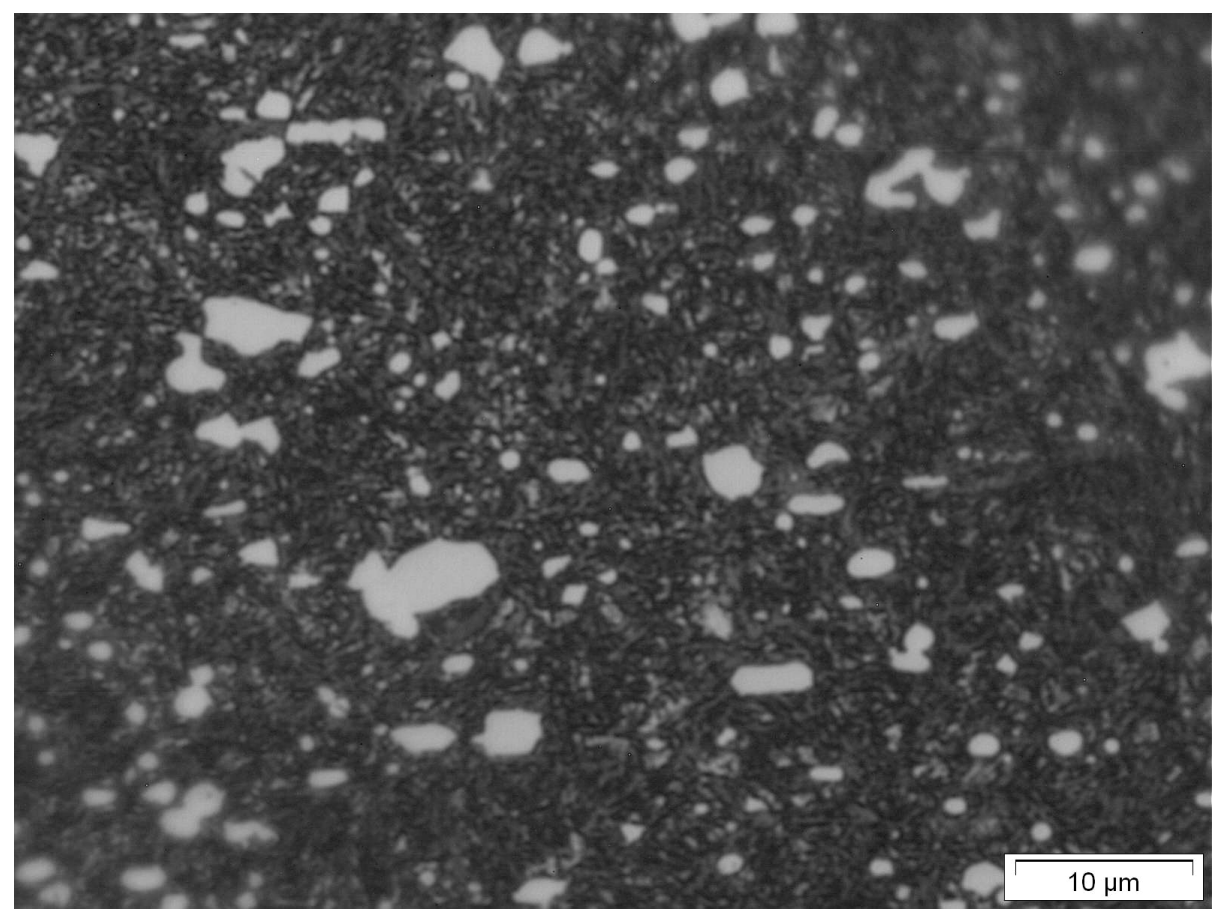

(a)

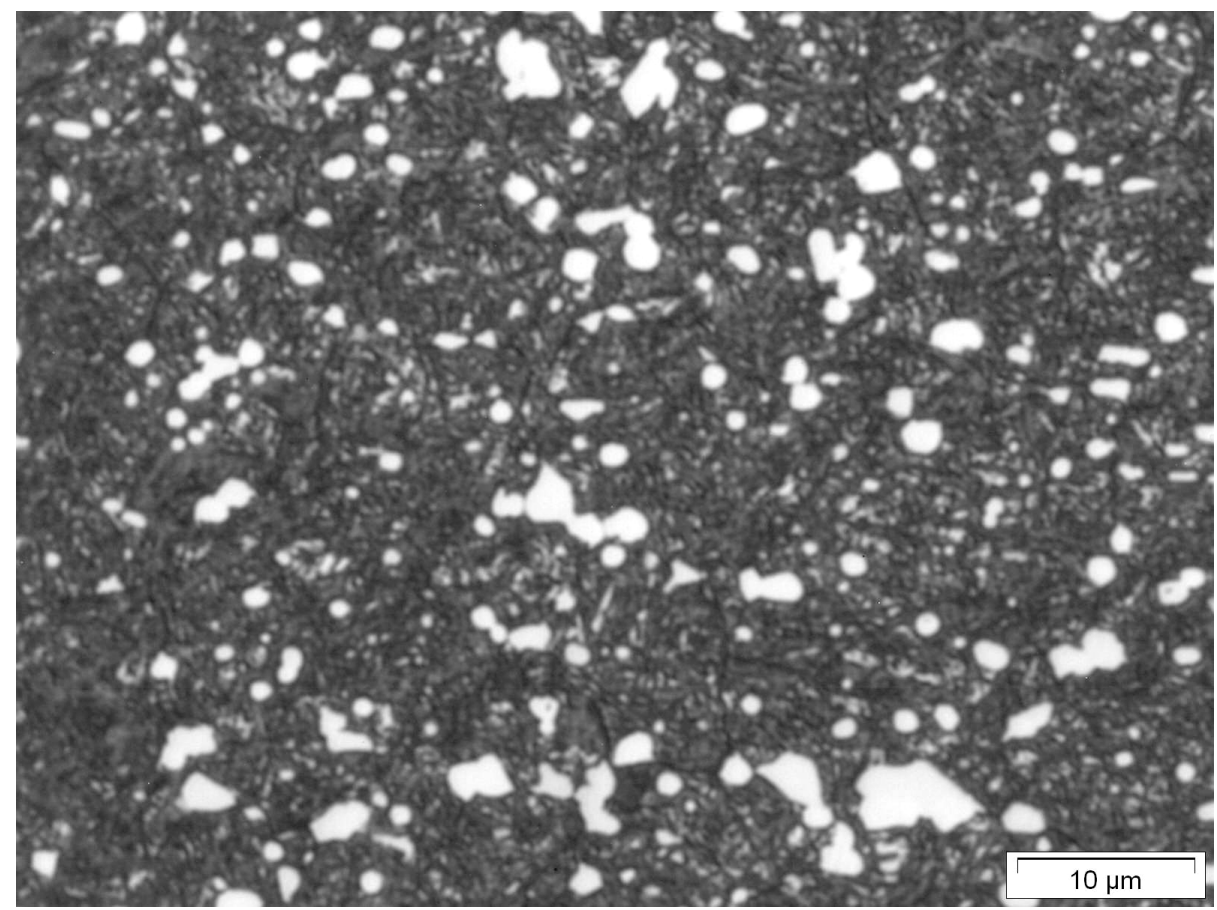

(b)

Figura 5.21 Microestrutura da ponta do dente de aço rápido M42 mostrando carbonetos globulares e bem distribuídos em matriz martensítica revenida isenta de austenita retida e de descarbonetação. Ataque: Villela - 12s. MO. Aumento 1.000X. (a) Amostra A3D1; (b) Amostra F1D2. 
Conforme observado nas figuras 5.20 e 5.21, o calor gerado na soldagem topo-a-topo por centelhamento das extremidades da serra de fita bimetálica não afetou a microestrutura dos dentes de aço rápido M42, uma vez que a microestrutura dos dentes da região da solda é similar a dos dentes de uma região onde não houve soldagem (F1D1 e F1D2). Isto está em conformidade com aplicações práticas da serra de fita bimetálica, onde não existem registros de não conformidades relativas a quebras ou falhas dos dentes na região da solda de forma prematura.

\subsection{RESULTADOS DAS MEDIÇÕES DE DUREZA.}

Foram realizados ensaios de microdureza Vickers em todas as amostras que foram extraídas transversalmente à LCS dos corpos de prova, nas amostras dos parâmetros A1, A2 e A3, que foram extraídas longitudinalmente à LCS dos corpos de prova e nas amostras dos parâmetros A1, A2, A3, C1, D3 e F1, que foram retirados da ponta dos dentes dos corpos de prova, conforme figuras 4.1 e 4.3 e tabela "Planejamento dos corpos de prova para ensaios de soldagem em serras de fita bimetálica de $27 \mathrm{~mm} "$ do anexo 01.

Os ensaios de microdureza foram executados nas mesmas amostras utilizadas para a caracterização microestrutural, que foram armazenadas sob vácuo durante o período de testes.

\subsubsection{Critério de Medição da Dureza nas Amostras.}

Conforme a literatura pesquisada sobre o processo de soldagem topo-a-topo por centelhamento $^{(19,21)}$, a seção transversal à LCS é mais representativa para fins de ensaios de dureza em relação à seção longitudinal, devido à deformação das linhas de fluxo de laminação 
das chapas através da força de recalque poder causar maior influência nas propriedades mecânicas do material. Por isto, neste trabalho foi selecionada a seção transversal à LCS como a de interesse para a verificação da dureza da junta soldada, em função dos diversos parâmetros testados. Foi também decidido verificar a dureza na seção longitudinal à LCS de algumas amostras, para fins de comparação com a dureza na seção transversal.

Baseado na medida da largura da ZAC de aproximadamente 1,30 $\mathrm{mm}$ e na espessura da amostra de aproximadamente $0,90 \mathrm{~mm}$, foi decidido verificar a dureza em 33 pontos em cada amostra da junta soldada, sendo 03 pontos na LCS, 18 pontos na ZAC e 12 pontos no metal de base próximo à interface com a ZAC, conforme figura 4.3 (b) e (c). As figuras 5.22 e 5.23 mostram os pontos de verificação de dureza no sentido transversal à LCS da amostra A2T2.

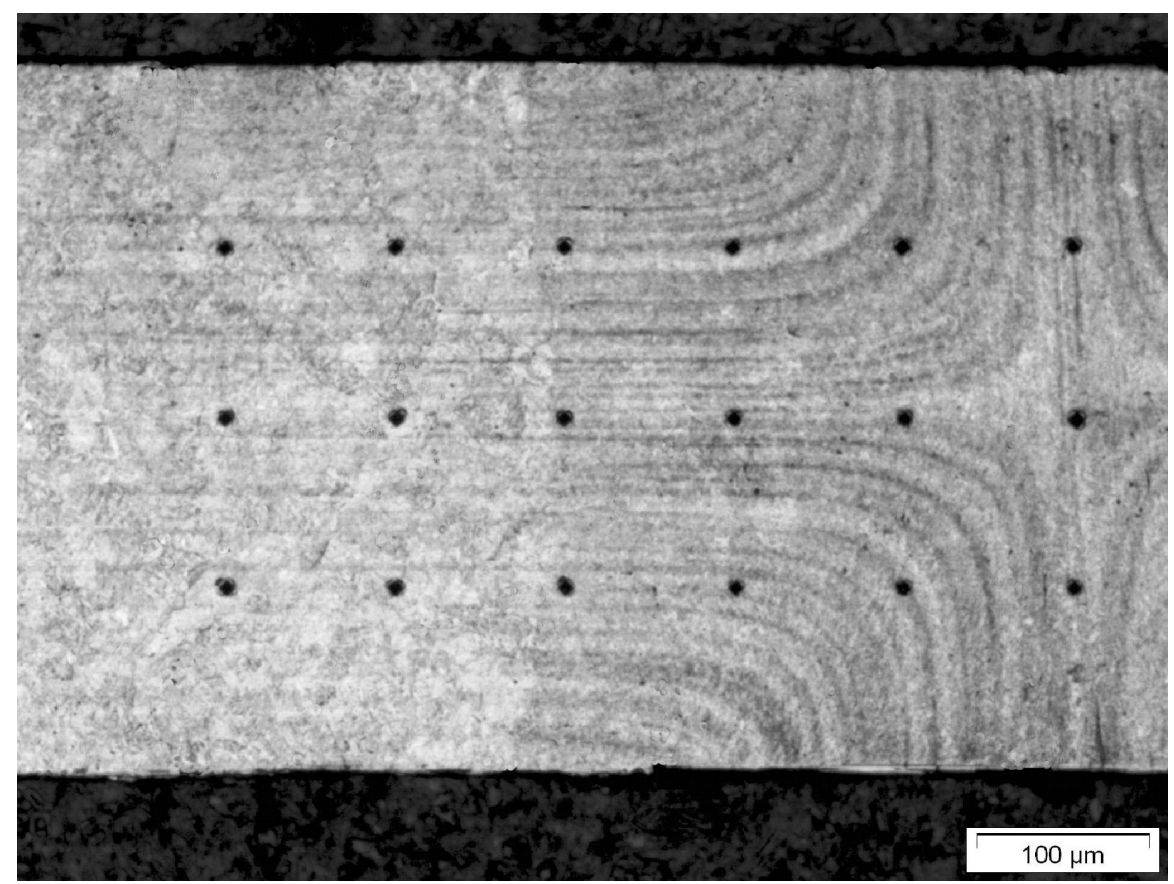

Figura 5.22 Pontos de verificação de dureza no sentido transversal à LCS da amostra A2T2. Ataque: Villela. MO. 100X. 


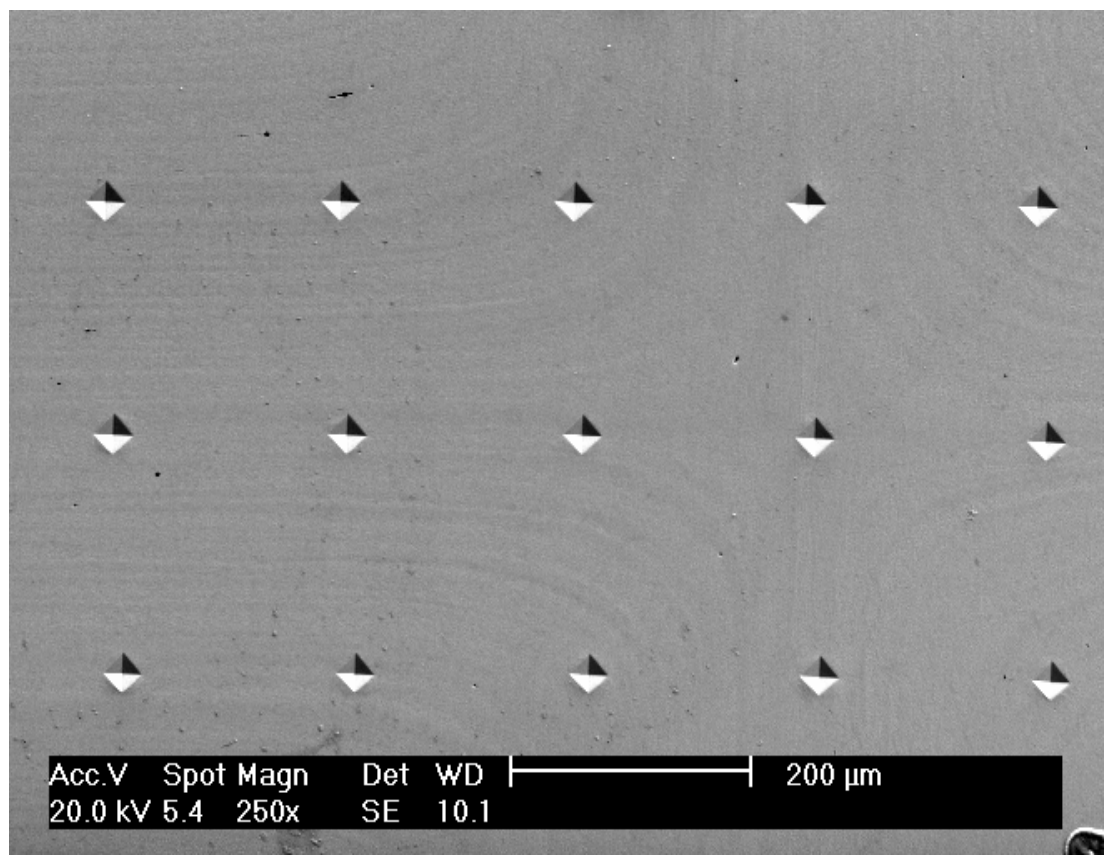

Figura 5.23 Pontos de verificação de dureza no sentido transversal à LCS da amostra A2T2. Ataque: Villela. MEV. 250X.

Conforme pode ser observado na figura 5.22, existem 03 pontos de verificação de dureza na LCS, 09 pontos na ZAC e 06 pontos no metal de base, ambos do lado esquerdo da LCS. Os pontos de verificação do lado direito da LCS são simétricos aos do lado esquerdo. Este critério foi utilizado para todas as amostras da junta soldada. Para a verificação da dureza na ponta dos dentes foram definidos 9 pontos de medição, conforme figura 4.3 (a).

\subsubsection{Definição da Carga de Teste.}

Os ensaios de dureza na região da solda e nas extremidades dos dentes próximos à região da solda foram executados com carga de $100 \mathrm{~g}$. A carga de $300 \mathrm{~g}$ também foi testada inicialmente, mas esta carga se mostrou excessiva para a determinação da dureza na LCS, caracterizada por uma faixa estreita de cor clara (ou escura para amostras "como soldado"), da ordem de $30 \mu \mathrm{m}$ de 
largura. A carga de 300g resultou em indentações prismáticas da ordem de 30 a $35 \mu$ mo material, que não se mostraram as mais indicadas para a identificação da dureza na LCS. A carga de $100 \mathrm{~g}$ resultou em indentações da ordem de 15 a $20 \mu \mathrm{m}$, tornando-se melhor indicada para a medição da dureza na LCS. As medições de durezas com cargas de $100 \mathrm{~g}$ e $300 \mathrm{~g}$ estão relacionadas na tabela 5.5 e gráfico da figura 5.24 a seguir.

Tabela 5.5 Variação da Dureza em Função da Carga de Teste.

\begin{tabular}{|c|c|c|c|c|c|c|c|c|c|c|c|}
\hline \multicolumn{12}{|c|}{ Variação da Dureza (HV) x Carga de Teste } \\
\hline \multirow{3}{*}{$\begin{array}{c}\text { Parâmetro } \\
\text { A2 }\end{array}$} & \multicolumn{11}{|c|}{ Distância da Linha Central da Solda (mm) } \\
\hline & \multicolumn{2}{|c|}{ MB } & \multicolumn{3}{|c|}{$\mathrm{ZAC}$} & LCS & \multicolumn{3}{|c|}{ ZAC } & \multicolumn{2}{|c|}{ MB } \\
\hline & $-1,0$ & $-0,8$ & $-0,6$ & $-0,4$ & $-0,2$ & 0 & 0,2 & 0,4 & 0,6 & 0,8 & 1,0 \\
\hline Média A2T3 & 470,0 & 467,7 & 509,3 & 526,0 & 522,3 & 486,7 & 513,7 & 489,3 & 478,7 & 457,0 & 466,0 \\
\hline$\sigma \mathrm{A} 2 \mathrm{~T} 3$ & 7,2 & 3,5 & 15,0 & 35,0 & 47,3 & 28,5 & 42,6 & 12,1 & 42,4 & 20,1 & 15,1 \\
\hline Média A2T4 & 442,7 & 445,0 & 487,0 & 495,7 & 492,3 & 498,0 & 496,3 & 503,0 & 474,3 & 456,0 & 450,3 \\
\hline$\sigma \mathrm{A} 2 \mathrm{~T} 4$ & 15,9 & 20,1 & 13,0 & 11,6 & 21,7 & 13,5 & 16,6 & 12,5 & 25,3 & 21,1 & 23,1 \\
\hline
\end{tabular}

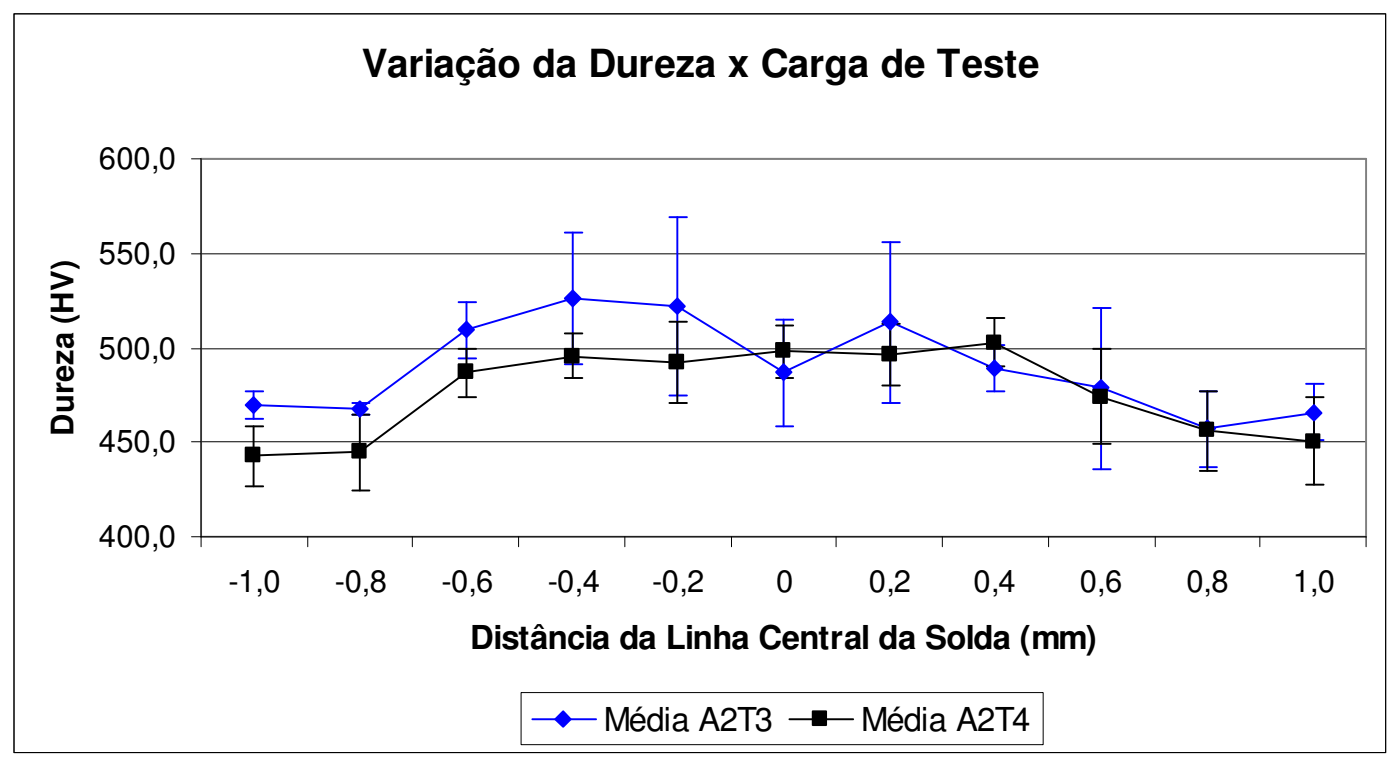

Figura 5.24 Variação da dureza em função da carga de teste. Sentido transversal à LCS. Amostra A2T3 com carga de 100g e amostra A2T4 com carga de 300g. 
As amostras A2T3 e A2T4 foram soldadas com o parâmetro recomendado A2, e foram confeccionadas com o objetivo de definição da carga de teste para os ensaios de dureza Vickers. Como pode ser notado no gráfico da figura 5.24, a curva representada pela linha preta, cujos valores de dureza foram medidos com carga de 300g, apresenta valor médio de dureza na LCS de 498,0 HV, enquanto que a curva representada pela linha azul, cujos valores de dureza foram medidos com carga de 100g, apresenta valor médio de dureza na LCS de 486,7 HV. Ou seja, nas medições efetuadas com carga de $100 \mathrm{~g}$ foi possível identificar uma redução de dureza na LCS em relação à ZAC, o que está em conformidade com a literatura pesquisada ${ }^{(19,21,33)}$

Outro aspecto a ser considerado é a maior dispersão apresentada pelas medidas de durezas efetuadas com carga de 100g, pois esta carga de menor intensidade fica mais sensível aos efeitos da microsegregação presente nas linhas de fluxo do material, representadas pelas linhas claras e escuras mostradas anteriormente nas figuras do item 5.1.1.

Analogamente, foi adotada a carga de 100 g, para a verificação de dureza da matriz de aço rápido M42 da ponta dos dentes da serra de fita bimetálica.

\subsubsection{Medições de Dureza na Microestrutura da Seção transversal à LCS.}

A LCS é a região mais crítica de uma solda topo-a-topo por centelhamento, pois é ela quem determina as propriedades mecânicas da junta soldada, Devido a este aspecto, foi feita uma investigação da dureza na LCS em todas as condições testadas. 


\subsubsection{Variação da Dureza na LCS em Função da Variação da Corrente Elétrica.}

Foram testadas três variações para o parâmetro corrente elétrica, em relação a seus efeitos na dureza da LCS, conforme a seguir:

A1: Corrente elétrica com redução de 14,3\% em relação ao valor recomendado.

A2: Corrente elétrica com valor recomendado, conforme tabela 4.5.

A3: Corrente elétrica com aumento de $14,3 \%$ em relação ao valor recomendado.

Os dados dos parâmetros A1, A2 e A3 estão relacionados na tabela "Planejamento dos corpos de prova para ensaios de soldagem em serras de fita bimetálica de $27 \mathrm{~mm} "$ do anexo 01 .

A tabela 5.6 e o gráfico da figura 5.25 mostram os valores de dureza na LCS, na ZAC e no MB para os parâmetros A1, A2 e A3 testados.

Tabela 5.6 Variação da Dureza na LCS em Função da Variação da Corrente Elétrica.

\begin{tabular}{|c|c|c|c|c|c|c|c|c|c|c|c|}
\hline \multicolumn{12}{|c|}{ Variação da Dureza (HV) x Variação da Corrente Elétrica. } \\
\hline \multirow{3}{*}{$\begin{array}{c}\text { Parâmetro } \\
\text { A }\end{array}$} & \multicolumn{11}{|c|}{ Distância da Linha Central da Solda $(\mathrm{mm})$} \\
\hline & \multicolumn{2}{|c|}{$\mathrm{MB}$} & \multicolumn{3}{|c|}{$\mathrm{ZAC}$} & LCS & \multicolumn{3}{|c|}{$\mathrm{ZAC}$} & \multicolumn{2}{|c|}{$\mathrm{MB}$} \\
\hline & $-1,0$ & $-0,8$ & $-0,6$ & $-0,4$ & $-0,2$ & 0 & 0,2 & 0,4 & 0,6 & 0,8 & 1,0 \\
\hline Média A1 & 483,5 & 477,8 & 512,5 & 517,5 & 507,8 & 472,2 & 487,8 & 493,2 & 502,0 & 484,7 & 485,3 \\
\hline$\sigma \mathrm{A} 1$ & 9,2 & 7,8 & 4,5 & 8,7 & 21,4 & 20,0 & 25,7 & 1,6 & 10,4 & 16,5 & 7,1 \\
\hline Média A2 & 484,7 & 497,3 & 517,7 & 508,7 & 526,8 & 485,3 & 512,0 & 521,8 & 519,3 & 489,5 & 497,5 \\
\hline$\sigma \mathrm{A} 2$ & 20,3 & 27,3 & 17,0 & 1,9 & 4,0 & 18,9 & 0,0 & 0,7 & 0,5 & 1,2 & 6,4 \\
\hline Média A3 & 488,8 & 487,5 & 526,0 & 521,7 & 516,3 & 525,7 & 513,7 & 508,7 & 518,8 & 489,8 & 475,7 \\
\hline$\sigma \mathrm{A} 3$ & 10,6 & 4,0 & 3,8 & 16,5 & 9,0 & 9,4 & 4,7 & 32,1 & 28,0 & 21,0 & 8,0 \\
\hline
\end{tabular}




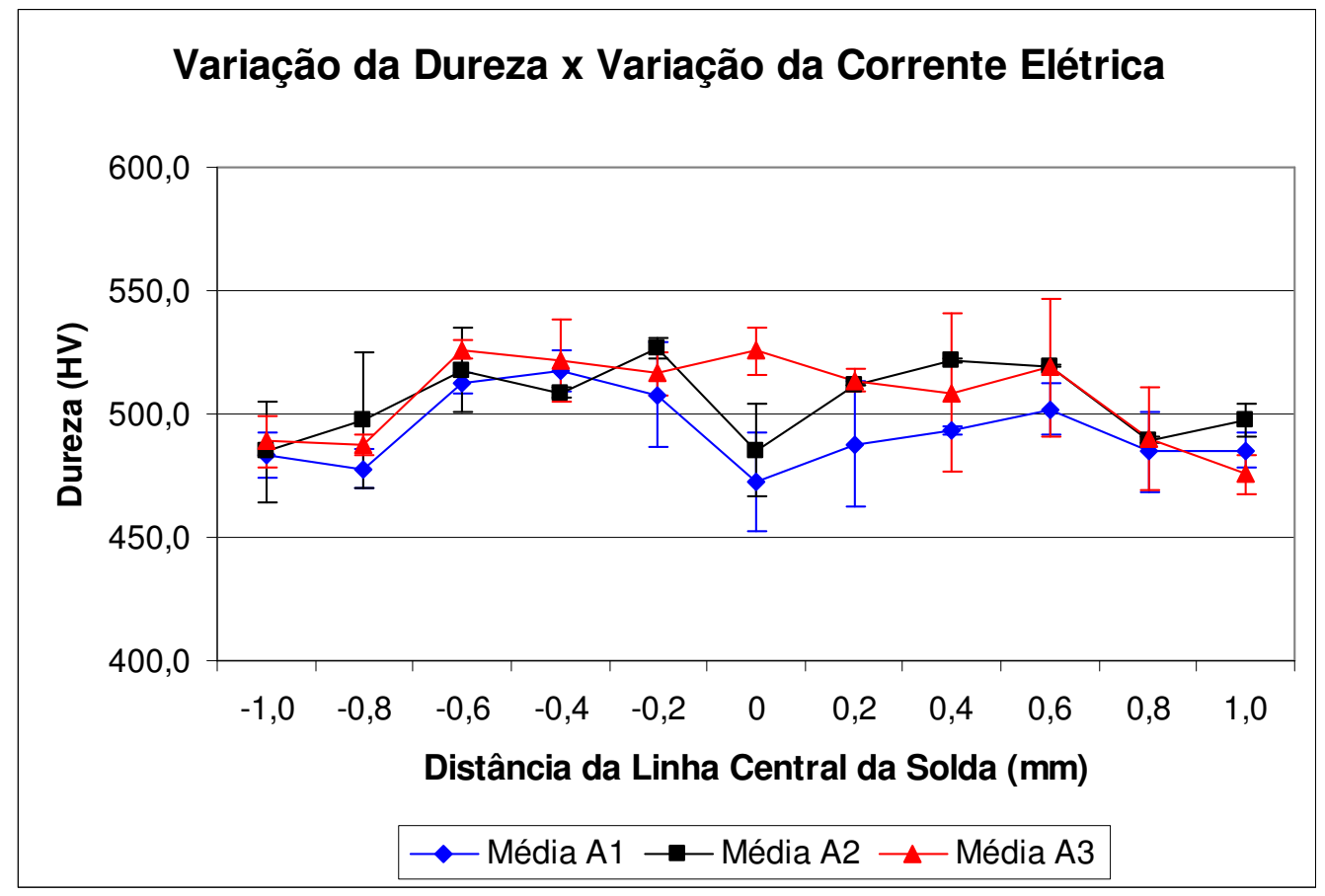

Figura 5.25 Variação da dureza na LCS em função da variação da corrente elétrica para os parâmetros A1, A2 e A3. Sentido transversal à LCS.

Conforme pode ser observado na tabela 5.6 e no gráfico da figura 5.25, o valor médio da dureza para o parâmetro A3 não apresentou queda na LCS conforme os parâmetros A1 e A2. Isto pode ser explicado através da tabela 5.2, onde pode ser observado que os corpos de prova A31 e A32, que deram origem às amostras A3T1 e A3T2, apresentaram uma distância final dos mordentes de 2,0 e 1,9 mm, respectivamente. Isto indica que uma quantidade maior de material da LCS foi expelida para fora da junta para formação da rebarba, e consequentemente, fez aumentar a dureza nesta região.

É razoável considerar que este fato ocorreu em função do aumento da intensidade da corrente elétrica ter provocado um maior aquecimento na LCS, e isto ter reduzido a resistência à 
compressão do material D-6a, fazendo com que a força de recalque expelisse a região de menor dureza para fora da junta soldada, juntamente com o material que resulta na rebarba.

Também pode ser observado na tabela 5.6 e figura 5.25, que a dureza mais elevada foi detectada na região da ZAC, que apresenta microestrutura mais fina. A LCS é o local de temperatura mais elevada e isto fez os grãos crescerem mais e a microestrutura ser mais grossa.

Os valores médios de dureza na LCS, resultantes dos testes com os parâmetros A1, A2 e A3, foram verificados pela Análise de Variância $^{(62)}$ e Testes de Hipóteses ${ }^{(63)}$, considerando-se dados emparelhados, conforme tabelas 5.7 e 5.8 a seguir.

Tabela 5.7 Análise de variância para dureza na LCS dos parâmetros A1, A2 e A3.

\begin{tabular}{|c|c|c|c|c|c|c|c|c|c|}
\hline \multicolumn{10}{|c|}{ Análise de Variância para Parâmetro A } \\
\hline \multirow[t]{3}{*}{ Amostra } & \multicolumn{9}{|c|}{ Dureza na LCS (HV) } \\
\hline & \multicolumn{3}{|c|}{$\mathrm{A} 1$} & \multicolumn{3}{|c|}{$\mathrm{A} 2$} & \multicolumn{3}{|c|}{ A3 } \\
\hline & $\mathrm{x}_{\mathrm{ij}}$ & $\mathrm{X}_{\mathrm{ij}-490}$ & $\mathrm{X}_{\mathrm{ij}-490^{2}}$ & $\mathrm{x}_{\mathrm{ij}}$ & $\mathrm{X}_{\mathrm{ij}-490}$ & $\mathrm{X}_{\mathrm{ij}-490^{2}}$ & $\mathrm{x}_{\mathrm{ij}}$ & $\mathrm{X}_{\mathrm{ij}-490}$ & $\mathrm{X}_{\mathrm{ij}-490^{2}}$ \\
\hline 1 & 493 & 3 & 9 & 495 & 5 & 25 & 525 & 35 & 1225 \\
\hline 2 & 388 & -102 & 10404 & 498 & 8 & 64 & 542 & 52 & 2704 \\
\hline 3 & 493 & 3 & 9 & 503 & 13 & 169 & 530 & 40 & 1600 \\
\hline 4 & 483 & -7 & 49 & 480 & -10 & 100 & 527 & 37 & 1369 \\
\hline 5 & 478 & -12 & 144 & 468 & -22 & 484 & 512 & 22 & 484 \\
\hline 6 & 498 & 8 & 64 & 468 & -22 & 484 & 518 & 28 & 784 \\
\hline Média & 472,2 & - & - & 485,3 & - & - & 525,7 & - & - \\
\hline$\sigma$ & 41,9 & - & - & 15,5 & - & - & 10,3 & - & - \\
\hline \multicolumn{2}{|c|}{ Fonte de Variação } & \multicolumn{2}{|c|}{$\begin{array}{c}\text { Soma de } \\
\text { Quadrados }\end{array}$} & \multicolumn{2}{|c|}{$\begin{array}{c}\text { Graus de } \\
\text { Liberdade }\end{array}$} & \multicolumn{2}{|c|}{$\begin{array}{c}\text { Quadrado } \\
\text { Médio }\end{array}$} & $\mathrm{F}$ & $\mathrm{F}_{\alpha}$ \\
\hline \multicolumn{2}{|c|}{ Entre Amostras } & \multicolumn{2}{|c|}{$9.324,78$} & \multicolumn{2}{|c|}{2} & \multicolumn{2}{|c|}{$4.662,39$} & 6,66 & $\mathrm{~F}_{15 ; 5 \%}=3,68$ \\
\hline \multicolumn{2}{|c|}{ Residual } & \multicolumn{2}{|c|}{$10.499,50$} & \multicolumn{2}{|c|}{15} & \multicolumn{2}{|c|}{699,97} & & \\
\hline \multicolumn{2}{|c|}{ Total } & \multicolumn{2}{|c|}{$19.824,28$} & \multicolumn{2}{|c|}{17} & \multicolumn{2}{|c|}{-} & & \\
\hline
\end{tabular}


Conforme pode ser visto na tabela 5.7, o valor para $\mathrm{F}$ calculado de 6,66 é maior que o valor para F tabelado $\left(\mathrm{F}_{15 ; 5 \%}\right)$ de 3,68, e, portanto, a hipótese $\mathrm{H}_{\mathrm{O}}$ é rejeitada. Isto permite concluir ao nível de 5\% de significância, que as três médias de durezas dos parâmetros A1, A2 e A3 são diferentes, e desta forma pode-se afirmar que a dureza na LCS variou em função da variação da corrente elétrica.

Do mesmo modo, conforme mostrado na tabela 5.8, os valores para $\mathrm{t}$ calculado $\left(\mathrm{t}_{5}\right)$ de $-2,63$ para a comparação das médias A1xA3 e de -10,42 para a comparação das médias A2xA3 são maiores em módulo que o valor para $\mathrm{t}$ tabelado $\left(\mathrm{t}_{5 ; 5 \%}\right)$ de 2,57. Por outro lado, o valor para $\mathrm{t}$ calculado $\left(\mathrm{t}_{5}\right)$ de -0,65 para a comparação das médias A1xA2 é menor em módulo que o valor para t tabelado $\left(t_{5 ; 5 \%}\right)$ de 2,57. Isto permite concluir, ao nível de 5\% de significância, que o valor médio de dureza na LCS para o parâmetro A3 é diferente dos respectivos valores de A1 e de A2, ao passo que os valores médios de durezas na LCS dos parâmetros A1 e A2 são iguais.

Tabela 5.8 Testes de hipóteses para dureza na LCS dos parâmetros A1, A2 e A3.

\begin{tabular}{|c|c|c|c|c|c|c|c|c|c|}
\hline \multicolumn{10}{|c|}{ Testes de Hipótese para Parâmetro A } \\
\hline \multirow[t]{2}{*}{ Amostra } & \multicolumn{3}{|c|}{ Dureza na LCS (HV) } & \multicolumn{2}{|c|}{$\mathrm{A} 1 \times \mathrm{A} 2$} & \multicolumn{2}{|c|}{$\mathrm{A} 1 \times \mathrm{A} 3$} & \multicolumn{2}{|c|}{$\mathrm{A} 2 \times \mathrm{A} 3$} \\
\hline & A1 & $\mathrm{A} 2$ & A3 & $\mathrm{d}_{\mathrm{A} 1 \mathrm{~A} 2}$ & $\mathrm{~d}_{\mathrm{A} 1 \mathrm{~A} 2}{ }^{2}$ & $\mathrm{~d}_{\mathrm{A} 1 \mathrm{~A} 3}$ & $\mathrm{~d}_{\mathrm{A} 1 \mathrm{~A} 3^{2}}$ & $\mathrm{~d}_{\mathrm{A} 2 \mathrm{~A} 3}$ & $\mathrm{~d}_{\mathrm{A} 2 \mathrm{~A} 3^{2}}$ \\
\hline 1 & 493 & 495 & 525 & -2 & 4 & -32 & 1.024 & -30 & 900 \\
\hline 2 & 388 & 498 & 542 & -110 & 12.100 & -154 & 23.716 & -44 & 1.936 \\
\hline 3 & 493 & 503 & 530 & -10 & 100 & -37 & 1.369 & -27 & 729 \\
\hline 4 & 483 & 480 & 527 & 3 & 9 & -44 & 1.936 & -47 & 2.209 \\
\hline 5 & 478 & 468 & 512 & 10 & 100 & -34 & 1.156 & -44 & 1.936 \\
\hline 6 & 498 & 468 & 518 & 30 & 900 & -20 & 400 & -50 & 2.500 \\
\hline & & & $\Sigma$ & -79 & 13.213 & -321 & 29.601 & -242 & 10.210 \\
\hline & & & $\mathrm{sd}^{2}$ & \multicolumn{2}{|c|}{$2.434,57$} & \multicolumn{2}{|c|}{$2.485,50$} & \multicolumn{2}{|c|}{89,87} \\
\hline & & & $\mathrm{sd}$ & \multicolumn{2}{|c|}{49,34} & \multicolumn{2}{|c|}{49,85} & \multicolumn{2}{|c|}{9,48} \\
\hline & & & $t_{5}$ & \multicolumn{2}{|c|}{$-0,65$} & \multicolumn{2}{|c|}{$-2,63$} & \multicolumn{2}{|c|}{$-10,42$} \\
\hline & & & $t_{5 ; 5 \%}$ & \multicolumn{6}{|c|}{2,57} \\
\hline
\end{tabular}


Desta forma, pode-se afirmar que o valor médio da dureza na LCS aumentou em 8,3\% quando a intensidade da corrente elétrica aumentou em 14,3\% em relação ao valor recomendado, e que não houve variação significativa de dureza, quando a corrente foi reduzida em 14,3\% em relação ao valor recomendado, conforme análises estatísticas anteriores e tabela 5.9 a seguir.

Tabela 5.9 Variação da dureza na LCS em função da variação da corrente elétrica.

\begin{tabular}{|c|c|c|c|c|c|}
\hline \multirow{3}{*}{ Parâmetro } & \multirow{2}{*}{ Tensão de Soldagem } & \multicolumn{2}{|c|}{ Corrente de Soldagem } & \multicolumn{2}{|c|}{ Dureza na LCS } \\
\hline & & Intensidade & Variação & Valor Médio & Variação \\
\hline & V & A & $\%$ & $\mathrm{HV}$ & $\%$ \\
\hline A1 & 3,6 & $4.706,6$ & $-14,3$ & 472,2 & $-2,7$ \\
\hline A2 & 4,2 & $5.491,9$ & 0,0 & 485,3 & 0,0 \\
\hline A3 & 4,8 & $6.277,2$ & 14,3 & 525,7 & $+8,3$ \\
\hline
\end{tabular}

\subsubsection{Variação da Dureza na LCS em Função da Variação da Força de Recalque.}

Foram testadas três variações para o parâmetro força de recalque, conforme a seguir:

B1: Força de recalque com redução de $25 \%$ em relação ao valor recomendado.

B2: Força de recalque com valor recomendado, conforme tabela 4.5.

B3: Força de recalque com aumento de $25 \%$ em relação ao valor recomendado.

A tabela 5.10 e o gráfico da figura 5.26 mostram os valores de dureza na LCS, na ZAC e no MB para os parâmetros B1, B2 e B3 testados.

Os dados dos parâmetros B1, B2 e B3 estão relacionados na tabela "Planejamento dos corpos de prova para ensaios de soldagem em serras de fita bimetálica de $27 \mathrm{~mm}$ " do anexo 01 . 
Tabela 5.10 Variação da Dureza na LCS em Função da Variação da Força de Recalque.

\begin{tabular}{|c|c|c|c|c|c|c|c|c|c|c|c|}
\hline \multicolumn{12}{|c|}{ Variação da Dureza (HV) x Variação da Força de Recalque. } \\
\hline \multirow{3}{*}{$\begin{array}{c}\text { Parâmetro } \\
\text { B }\end{array}$} & \multicolumn{11}{|c|}{ Distância da Linha Central da Solda (mm) } \\
\hline & \multicolumn{2}{|c|}{ MB } & \multicolumn{3}{|c|}{ ZAC } & \multirow{2}{*}{$\begin{array}{c}\text { LCS } \\
0\end{array}$} & \multicolumn{3}{|c|}{ ZAC } & \multicolumn{2}{|c|}{ MB } \\
\hline & $-1,0$ & $-0,8$ & $-0,6$ & $-0,4$ & $-0,2$ & & 0,2 & 0,4 & 0,6 & 0,8 & 1,0 \\
\hline Média B1 & 456,2 & 488,2 & 495,5 & 474,2 & 482,0 & 459,2 & 474,3 & 457,2 & 505,5 & 502,8 & 476,8 \\
\hline$\sigma \mathrm{B} 1$ & 23,3 & 18,6 & 32,8 & 47,8 & 30,6 & 31,3 & 15,6 & 3,5 & 18,1 & 15,3 & 8,2 \\
\hline Média B2 & 484,7 & 497,3 & 517,7 & 508,7 & 526,8 & 485,3 & 512,0 & 521,8 & 519,3 & 489,5 & 497,5 \\
\hline$\sigma \mathrm{B} 2$ & 20,3 & 27,3 & 17,0 & 1,9 & 4,0 & 18,9 & 0,0 & 0,7 & 0,5 & 1,2 & 6,4 \\
\hline Média B3 & 455,3 & 462,7 & 484,5 & 505,8 & 503,0 & 502,7 & 502,5 & 516,3 & 509,5 & 487,5 & 476,2 \\
\hline$\sigma \mathrm{B} 3$ & 11,8 & 23,1 & 5,9 & 4,0 & 21,2 & 4,2 & 3,5 & 29,7 & 39,4 & 19,1 & 10,6 \\
\hline
\end{tabular}

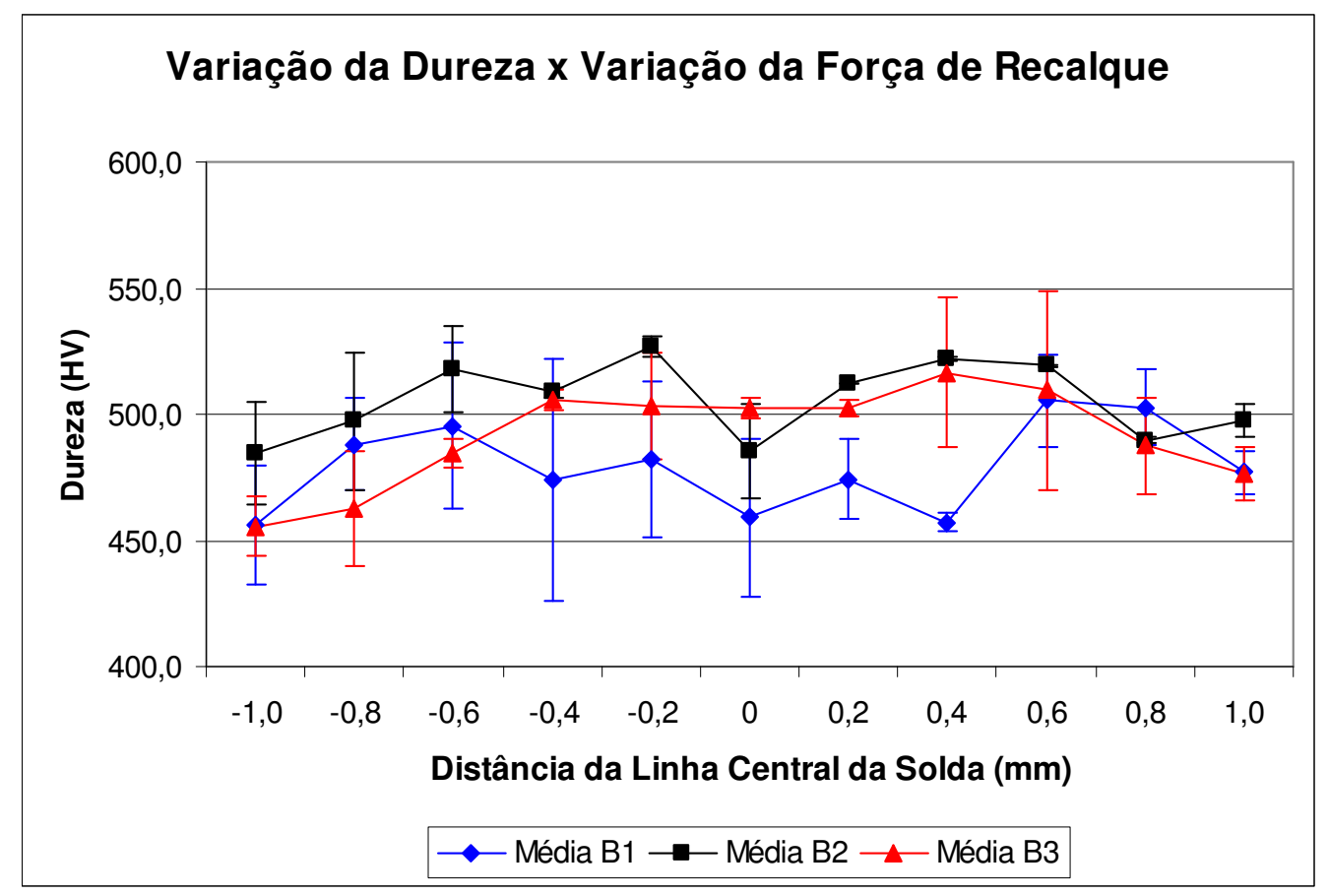

Figura 5.26 Variação da dureza na LCS em função da variação da força de recalque para os parâmetros B1, B2 e B3. Sentido transversal à LCS.

Os valores médios de dureza na LCS, resultantes dos testes com os parâmetros B1, B2 e B3, foram verificados pela Análise de Variância $^{(62)}$ e Testes de Hipóteses ${ }^{(63)}$, considerando-se dados emparelhados, conforme tabelas 5.11 e 5.12 a seguir. 
Conforme pode ser visto na tabela 5.11, o valor para $\mathrm{F}$ calculado de 3,04 é menor que o valor para $\mathrm{F}$ tabelado $\left(\mathrm{F}_{15 ; 5 \%}\right)$ de 3,68, e, portanto, a hipótese $\mathrm{H}_{\mathrm{O}}$ é aceita . Isto permite concluir ao nível de 5\% de significância, que as três médias de durezas dos parâmetros B1, B2 e B3 são iguais, e desta forma não se pode afirmar que a dureza na LCS variou em função da variação da força de recalque.

Tabela 5.11 Análise de variância para dureza na LCS dos parâmetros B1, B2 e B3.

\begin{tabular}{|c|c|c|c|c|c|c|c|c|c|}
\hline \multicolumn{10}{|c|}{ Análise de Variância para Parâmetro B } \\
\hline \multirow[t]{3}{*}{ Amostra } & \multicolumn{9}{|c|}{ Dureza na LCS (HV) } \\
\hline & \multicolumn{3}{|c|}{ B1 } & \multicolumn{3}{|c|}{$\mathrm{B} 2$} & \multicolumn{3}{|c|}{ B3 } \\
\hline & $x_{i j}$ & $\mathrm{x}_{\mathrm{ij}-490}$ & $\mathrm{X}_{\mathrm{ij}-490^{2}}$ & $\mathrm{x}_{\mathrm{ij}}$ & $\mathrm{x}_{\mathrm{ij}-490}$ & $\mathrm{X}_{\mathrm{ij}-490^{2}}$ & $\mathrm{x}_{\mathrm{ij}}$ & $\mathrm{x}_{\mathrm{ij}-490}$ & $\mathrm{X}_{\mathrm{ij}-490^{2}}$ \\
\hline 1 & 437 & -53 & 2809 & 495 & 5 & 25 & 516 & 26 & 676 \\
\hline 2 & 441 & -49 & 2401 & 498 & 8 & 64 & 493 & 3 & 9 \\
\hline 3 & 433 & -57 & 3249 & 503 & 13 & 169 & 490 & 0 & 0 \\
\hline 4 & 488 & -2 & 4 & 480 & -10 & 100 & 443 & -47 & 2209 \\
\hline 5 & 461 & -29 & 841 & 468 & -22 & 484 & 498 & 8 & 64 \\
\hline 6 & 495 & 5 & 25 & 468 & -22 & 484 & 576 & 86 & 7396 \\
\hline Média & 459,2 & - & - & 485,3 & - & - & 502,7 & - & - \\
\hline$\sigma$ & 26,9 & - & - & 15,5 & - & - & 43,3 & - & - \\
\hline \multicolumn{2}{|c|}{ Fonte de Variação } & \multicolumn{2}{|c|}{$\begin{array}{c}\text { Soma de } \\
\text { Quadrados }\end{array}$} & \multicolumn{2}{|c|}{$\begin{array}{c}\text { Graus de } \\
\text { Liberdade }\end{array}$} & \multicolumn{2}{|c|}{$\begin{array}{c}\text { Quadrado } \\
\text { Médio } \\
\end{array}$} & $\mathrm{F}$ & $\mathrm{F}_{\alpha}$ \\
\hline \multicolumn{2}{|c|}{ Entre Amostras } & \multicolumn{2}{|c|}{$5.754,78$} & \multicolumn{2}{|c|}{2} & \multicolumn{2}{|c|}{$2.877,39$} & 3,04 & $F_{15 ; 5 \%}=3,68$ \\
\hline \multicolumn{2}{|c|}{ Residual } & \multicolumn{2}{|c|}{$14.211,50$} & \multicolumn{2}{|c|}{15} & \multicolumn{2}{|c|}{947,43} & & \\
\hline \multicolumn{2}{|c|}{ Total } & \multicolumn{2}{|c|}{$19.966,28$} & \multicolumn{2}{|c|}{17} & & & & \\
\hline
\end{tabular}

Do mesmo modo, conforme mostrado na tabela 5.12, os valores para $\mathrm{t}$ calculado $\left(\mathrm{t}_{5}\right)$ de $-1,58$; -2,29 e -0,84 para a comparação das médias B1xB2, B1xB3 e B2xB3, respectivamente, são menores em módulo que o valor para $\mathrm{t}$ tabelado $\left(\mathrm{t}_{5 ; 5 \%}\right)$ de 2,57. Isto permite concluir, ao nível de 5\% de significância, que os valores médios de durezas na LCS dos parâmetros B1, B2 e B3 são iguais. 
Tabela 5.12 Testes de hipóteses para dureza na LCS dos parâmetros B1, B2 e B3.

\begin{tabular}{|c|c|c|c|c|c|c|c|c|c|}
\hline \multicolumn{10}{|c|}{ Testes de Hipótese para Parâmetro B } \\
\hline \multirow[t]{2}{*}{ Amostra } & \multicolumn{3}{|c|}{ Dureza na LCS (HV) } & \multicolumn{2}{|c|}{$\mathrm{B} 1 \times \mathrm{B} 2$} & \multicolumn{2}{|c|}{ B1 x B3 } & \multicolumn{2}{|c|}{$\mathrm{B} 2 \times \mathrm{B} 3$} \\
\hline & $\mathrm{B} 1$ & $\mathrm{~B} 2$ & B3 & $\mathrm{d}_{\mathrm{B} 1 \mathrm{~B} 2}$ & $\mathrm{~d}_{\mathrm{B} 1 \mathrm{~B} 2}{ }^{2}$ & $\mathrm{~d}_{\mathrm{B} 1 \mathrm{~B} 3}$ & $\mathrm{~d}_{\mathrm{B} 1 \mathrm{~B} 3}{ }^{2}$ & $\mathrm{~d}_{\mathrm{B} 2 \mathrm{~B} 3}$ & $\mathrm{~d}_{\mathrm{B} 2 \mathrm{~B} 3^{2}}$ \\
\hline 1 & 437 & 495 & 516 & -58 & 3.364 & -79 & 6.241 & -21 & 441 \\
\hline 2 & 441 & 498 & 493 & -57 & 3.249 & -52 & 2.704 & 5 & 25 \\
\hline 3 & 433 & 503 & 490 & -70 & 4.900 & -57 & 3.249 & 13 & 169 \\
\hline 4 & 488 & 480 & 443 & 8 & 64 & 45 & 2.025 & 37 & 1.369 \\
\hline 5 & 461 & 468 & 498 & -7 & 49 & -37 & 1.369 & -30 & 900 \\
\hline 6 & 495 & 468 & 576 & 27 & 729 & -81 & 6.561 & -108 & 11.664 \\
\hline & & & $\Sigma$ & -157 & 12.355 & -261 & 22.149 & -104 & 14.568 \\
\hline & & & $\mathrm{sd}^{2}$ & \multicolumn{2}{|c|}{$1.649,37$} & \multicolumn{2}{|c|}{$2.159,10$} & \multicolumn{2}{|c|}{$2.553,07$} \\
\hline & & & $\mathrm{sd}$ & \multicolumn{2}{|c|}{40,61} & \multicolumn{2}{|c|}{46,47} & \multicolumn{2}{|c|}{50,53} \\
\hline & & & $t_{5}$ & \multicolumn{2}{|c|}{$-1,58$} & \multicolumn{2}{|c|}{$-2,29$} & \multicolumn{2}{|c|}{$-0,84$} \\
\hline & & & $t_{5 ; 5 \%}$ & \multicolumn{6}{|c|}{2,57} \\
\hline
\end{tabular}

Desta forma, estatisticamente não se pode afirmar que o valor médio de dureza na LCS variou, quando a força de recalque variou em $\pm 25,0 \%$ em relação ao valor recomendado (A2), apesar das variações de dureza indicadas na tabela 5.13 a seguir. Isto está em conformidade com a literatura, onde Krishnaraj et al $^{(64)}$ concluíram ao testar chapas de aço carbono que a força de recalque não afetou a dureza da junta soldada.

Tabela 5.13 Variação da Dureza na LCS em Função da Variação da Força de Recalque.

\begin{tabular}{|c|c|c|c|c|}
\hline Parâmetro & \multicolumn{2}{|c|}{ Pressão de Recalque } & \multicolumn{2}{c|}{ Dureza na LCS } \\
\hline & Valor & Variação & Valor Médio & Variação \\
\cline { 2 - 5 } & MPa & $\%$ & HV & $\%$ \\
\hline B1 & 0,15 & $-25,0$ & 459,2 & $-5,4$ \\
\hline B2 (A2) & 0,20 & 0,0 & 485,3 & 0,0 \\
\hline B3 & 0,25 & $+25,0$ & 502,7 & $+3,6$ \\
\hline
\end{tabular}

As médias de dureza dos parâmetros B1, B2 e B3 são iguais estatisticamente, conforme demonstrado pelo teste de hipóteses da tabela 5.12. A média de dureza B3 é levemente superior à B2, conforme tabela 5.13, o que mostra que a dureza na LCS também aumentou com o aumento 
da força de recalque em relação ao valor recomendado B2 (A2). Entretanto, este aumento foi mínimo e isto leva a deduzir que o aumento de $25 \%$ na força de recalque não foi suficiente para vencer a resistência à compressão a quente do material D-6a durante a soldagem, uma vez que a corrente elétrica foi mantida a mesma durante a fase de centelhamento, e, por consequiência, também a energia de soldagem. O mesmo conceito se aplica para a média de dureza B1 em relação à $\mathrm{B} 2$, ou seja, com a corrente de soldagem tendo sido mantida a mesma, a redução na força de recalque não teve efeito significativo na dureza da junta soldada. O gráfico da figura 5.27 mostra a variação da dureza na LCS em função da variação da pressão de recalque.

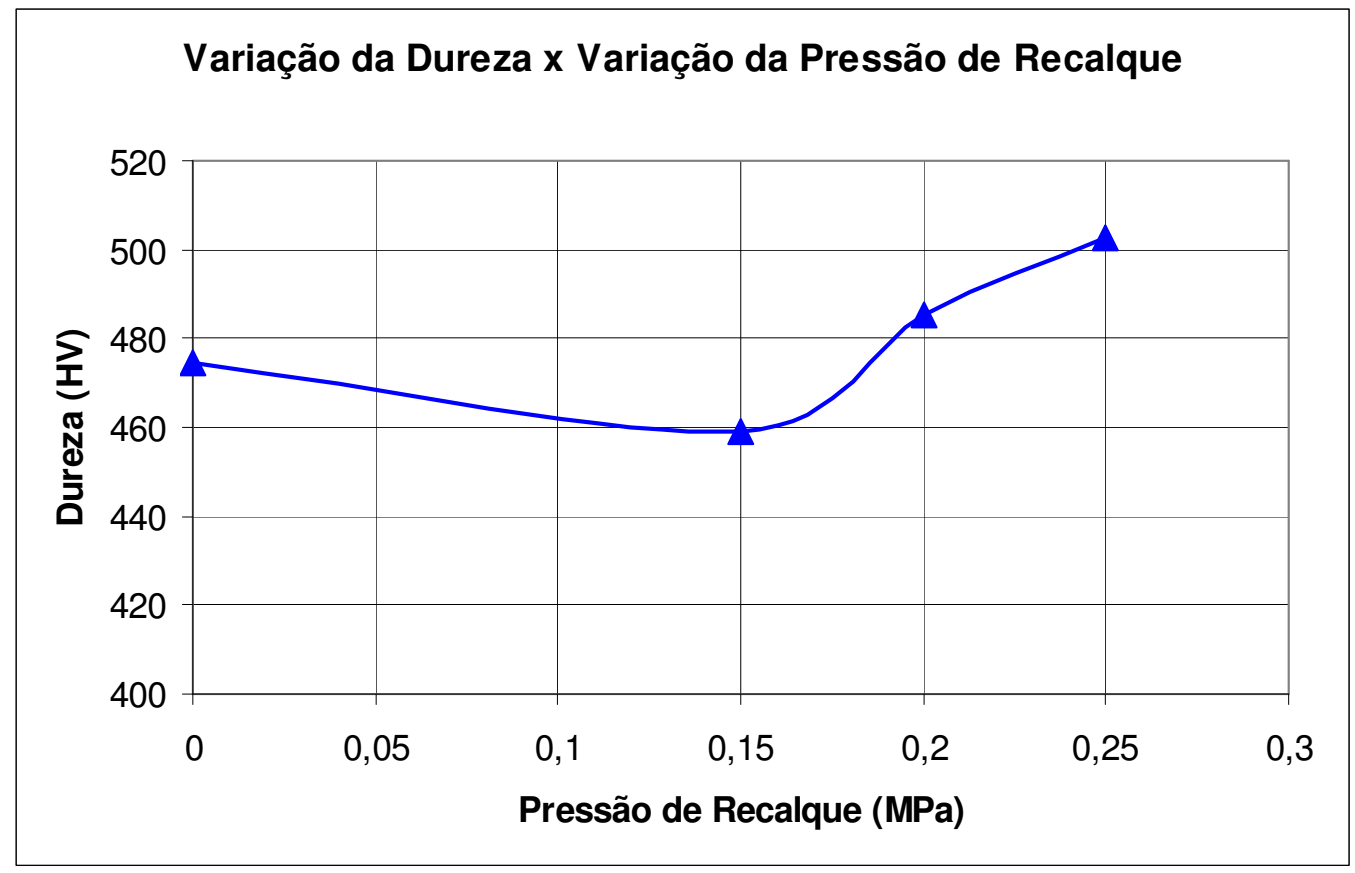

Figura 5.27 Variação da dureza na LCS em função da variação da pressão de recalque. Sentido transversal à LCS.

$\mathrm{O}$ aumento de 3,6\% na dureza do parâmetro B3 em relação à B2 pode ser explicado pela expulsão de um pouco mais de material aquecido da LCS em relação ao parâmetro B2, pela força de recalque. Isto pode ser verificado através dos menores valores para a distância final dos 
mordentes dos parâmetros B31 (2,0mm) e B32 (2,1mm) em relação a A21 (2,2mm) e A22 $(2,1 \mathrm{~mm})$, conforme indicado na tabela 5.2. O mesmo se aplica em relação à redução de 5,4\% na dureza do parâmetro B1 em relação ao parâmetro B2, onde os valores para distância final dos mordentes dos parâmetros B11 e B12 foram 2,5mm e 2,4mm, respectivamente.

\subsubsection{Variação da Dureza na LCS em Função da Quantidade de Revenidos.}

Foram testadas três condições com relação à quantidade de revenidos após a soldagem:

C1: sem revenido.

C2: com três revenidos (parâmetro recomendado), conforme tabela 4.5.

C3: com dois revenidos.

Os dados dos parâmetros C1, C2 e C3 estão relacionados na tabela "Planejamento dos corpos de prova para ensaios de soldagem em serras de fita bimetálica de $27 \mathrm{~mm}$ ” do anexo 01 .

A tabela 5.14 e o gráfico da figura 5.28 mostram os valores de dureza na LCS, na ZAC e no MB para os parâmetros C1, C2 e C3 testados. 
Tabela 5.14 Variação da Dureza na LCS em Função da Variação da Quantidade de Revenidos.

\begin{tabular}{|c|c|c|c|c|c|c|c|c|c|c|c|}
\hline \multicolumn{12}{|c|}{ Variação da Dureza (HV) x Quantidade de Revenidos. } \\
\hline \multirow{3}{*}{$\begin{array}{c}\text { Parâmetro } \\
\text { C }\end{array}$} & \multicolumn{11}{|c|}{ Distância da Linha Central da Solda (mm) } \\
\hline & \multicolumn{2}{|c|}{ MB } & \multicolumn{3}{|c|}{ ZAC } & \multirow{2}{*}{$\begin{array}{c}\text { LCS } \\
0\end{array}$} & \multicolumn{3}{|c|}{ ZAC } & \multicolumn{2}{|c|}{ MB } \\
\hline & $-1,0$ & $-0,8$ & $-0,6$ & $-0,4$ & $-0,2$ & & 0,2 & 0,4 & 0,6 & 0,8 & 1,0 \\
\hline Média C1 & 475,2 & 473,3 & 787,2 & 798,3 & 801,0 & 730,8 & 758,7 & 777,7 & 777,7 & 477,2 & 480,3 \\
\hline$\sigma \mathrm{C} 1$ & 7,3 & 9,0 & 2,1 & 39,6 & 28,8 & 56,3 & 55,2 & 2,8 & 21,2 & 5,9 & 0,9 \\
\hline Média C2 & 484,7 & 497,3 & 517,7 & 508,7 & 526,8 & 485,3 & 512,0 & 521,8 & 519,3 & 489,5 & 497,5 \\
\hline$\sigma \mathrm{C} 2$ & 20,3 & 27,3 & 17,0 & 1,9 & 4,0 & 18,9 & 0,0 & 0,7 & 0,5 & 1,2 & 6,4 \\
\hline Média C3 & 496,7 & 475,2 & 507,3 & 499,8 & 500,2 & 494,0 & 491,5 & 503,8 & 495,3 & 466,5 & 462,7 \\
\hline$\sigma \mathrm{C} 3$ & 14,1 & 4,0 & 10,4 & 3,5 & 16,7 & 18,4 & 16,7 & 15,3 & 8,5 & 31,3 & 32,1 \\
\hline
\end{tabular}

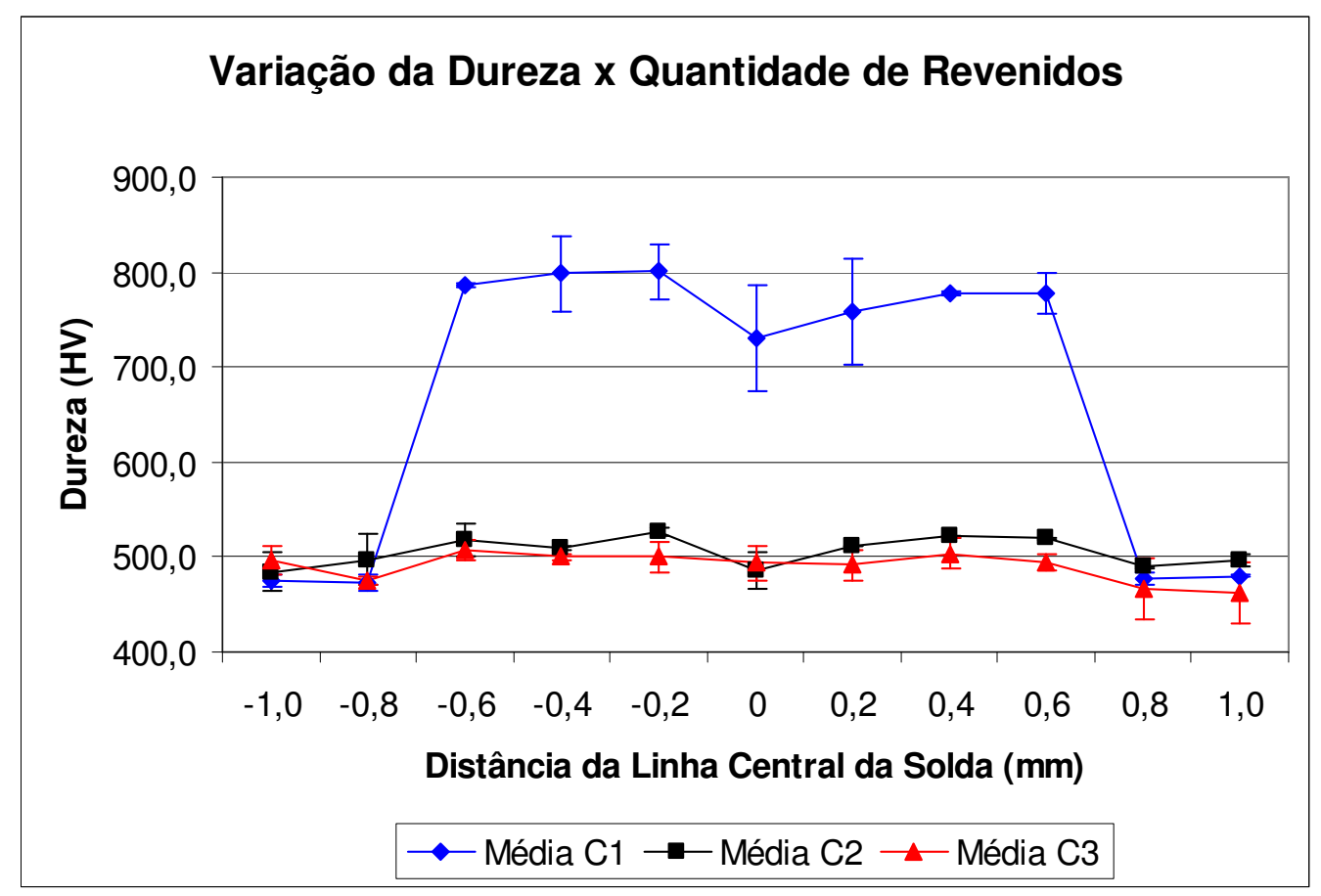

Figura 5.28 Variação da dureza na LCS em função da variação da quantidade de revenidos para os parâmetros C1, C2 e C3. Sentido transversal à LCS.

Os valores médios de dureza na LCS, resultantes dos testes com os parâmetros C1, C2 e C3, foram verificados pela Análise de Variância $^{(62)}$ e Testes de Hipóteses ${ }^{(63)}$, considerando-se dados emparelhados, conforme tabelas 5.15 e 5,16 a seguir. 
Conforme pode ser visto na tabela 5.15, o valor para $\mathrm{F}$ calculado de 107,28 é maior que o valor para $\mathrm{F}$ tabelado $\left(\mathrm{F}_{15 ; 5 \%}\right)$ de 3,68. Isto permite concluir ao nível de 5\% de significância, que as três médias de durezas dos parâmetros C1, C2 e C3 são diferentes, e desta forma pode-se afirmar que a dureza na LCS variou em função da quantidade de revenidos.

Tabela 5.15 Análise de variância para dureza na LCS dos parâmetros C1, C2 e C3.

\begin{tabular}{|c|c|c|c|c|c|c|c|c|c|}
\hline \multicolumn{10}{|c|}{ Análise de Variância para Parâmetro C } \\
\hline \multirow[t]{3}{*}{ Amostra } & \multicolumn{9}{|c|}{ Dureza na LCS (HV) } \\
\hline & \multicolumn{3}{|c|}{$\mathrm{C} 1$} & \multicolumn{3}{|c|}{$\mathrm{C} 2$} & \multicolumn{3}{|c|}{$\mathrm{C} 3$} \\
\hline & $\mathrm{X}_{\mathrm{ij}}$ & $\mathrm{X}_{\mathrm{ij}-490}$ & $\mathrm{X}_{\mathrm{ij}-490^{2}}$ & $\mathrm{X}_{\mathrm{ij}}$ & $\mathrm{X}_{\mathrm{ij}-490}$ & $\mathrm{X}_{\mathrm{ij}-490^{2}}$ & $\mathrm{x}_{\mathrm{ij}}$ & $\mathrm{X}_{\mathrm{ij}-490}$ & $\mathrm{X}_{\mathrm{ij}-490^{2}}$ \\
\hline 1 & 673 & 183 & 33489 & 495 & 5 & 25 & 506 & 16 & 256 \\
\hline 2 & 715 & 225 & 50625 & 498 & 8 & 64 & 457 & -33 & 1089 \\
\hline 3 & 685 & 195 & 38025 & 503 & 13 & 169 & 480 & -10 & 100 \\
\hline 4 & 782 & 292 & 85264 & 480 & -10 & 100 & 488 & -2 & 4 \\
\hline 5 & 738 & 248 & 61504 & 468 & -22 & 484 & 527 & 37 & 1369 \\
\hline 6 & 792 & 302 & 91204 & 468 & -22 & 484 & 506 & 16 & 256 \\
\hline Média & 730,8 & - & - & 485,3 & - & - & 494,0 & - & - \\
\hline$\sigma$ & 49,2 & - & - & 15,5 & - & - & 24,4 & - & - \\
\hline \multicolumn{2}{|c|}{ Fonte de Variação } & \multicolumn{2}{|c|}{$\begin{array}{c}\text { Soma de } \\
\text { Quadrados }\end{array}$} & \multicolumn{2}{|c|}{$\begin{array}{l}\text { Graus de } \\
\text { Liberdade }\end{array}$} & \multicolumn{2}{|c|}{$\begin{array}{c}\text { Quadrado } \\
\text { Médio } \\
\end{array}$} & $\mathrm{F}$ & $\mathrm{F}_{\alpha}$ \\
\hline \multicolumn{2}{|c|}{ Entre Amostras } & \multicolumn{2}{|c|}{$232.870,78$} & \multicolumn{2}{|c|}{2} & \multicolumn{2}{|c|}{$116.435,39$} & 107,28 & $\mathrm{~F}_{15 ; 5 \%}=3,68$ \\
\hline \multicolumn{2}{|c|}{ Residual } & \multicolumn{2}{|c|}{$16.280,17$} & \multicolumn{2}{|c|}{15} & \multicolumn{2}{|c|}{$1.085,34$} & & \\
\hline \multicolumn{2}{|c|}{ Total } & \multicolumn{2}{|c|}{$249.150,94$} & \multicolumn{2}{|c|}{17} & & & & \\
\hline
\end{tabular}

Analogamente, conforme mostrado na tabela 5.16, os valores para t calculado $\left(\mathrm{t}_{5}\right)$ de 9,67 para a comparação das médias $\mathrm{C} 1 \times \mathrm{xC} 2$ e de 11,51 para a comparação das médias $\mathrm{C} 1$ xC3 são maiores que o valor para $t$ tabelado $\left(t_{5 ; 5 \%}\right)$ de 2,57 . Por outro lado, o valor para t calculado $\left(t_{5}\right)$ de $-0,57$ para a comparação das médias C2xC3 é menor em módulo que o valor para t tabelado $\left(\mathrm{t}_{5 ; 5 \%}\right)$ de 2,57. Isto permite concluir, ao nível de 5\% de significância, que o valor médio de dureza na LCS para 
o parâmetro $\mathrm{C} 1$ é diferente dos respectivos valores para $\mathrm{C} 2$ e C3, ao passo que os valores médios de durezas na LCS para os parâmetros C2 e C3 são iguais.

Tabela 5.16 Testes de hipóteses para dureza na LCS dos parâmetros C1, C2 e C3.

\begin{tabular}{|c|c|c|c|c|c|c|c|c|c|}
\hline \multicolumn{10}{|c|}{ Testes de Hipótese para Parâmetro C } \\
\hline \multirow[t]{2}{*}{ Amostra } & \multicolumn{3}{|c|}{ Dureza na LCS (HV) } & \multicolumn{2}{|c|}{$\mathrm{C} 1 \times \mathrm{C} 2$} & \multicolumn{2}{|c|}{$\mathrm{C} 1 \times \mathrm{C} 3$} & \multicolumn{2}{|c|}{$\mathrm{C} 2 \times \mathrm{C} 3$} \\
\hline & $\mathrm{C} 1$ & $\mathrm{C} 2$ & $\mathrm{C} 3$ & $\mathrm{~d}_{\mathrm{ClC} 2}$ & $\mathrm{~d}_{\mathrm{ClC} 2}{ }^{2}$ & $\mathrm{~d}_{\mathrm{ClC} 3}$ & $\mathrm{~d}_{\mathrm{ClC} 3}{ }^{2}$ & $\mathrm{~d}_{\mathrm{C} 2 \mathrm{C} 3}$ & $\mathrm{~d}_{\mathrm{C} 2 \mathrm{C}^{2}}$ \\
\hline 1 & 673 & 495 & 506 & 178 & 31.684 & 167 & 27.889 & -11 & 121 \\
\hline 2 & 715 & 498 & 457 & 217 & 47.089 & 258 & 66.564 & 41 & 1.681 \\
\hline 3 & 685 & 503 & 480 & 182 & 33.124 & 205 & 42.025 & 23 & 529 \\
\hline 4 & 782 & 480 & 488 & 302 & 91.204 & 294 & 86.436 & -8 & 64 \\
\hline 5 & 738 & 468 & 527 & 270 & 72.900 & 211 & 44.521 & -59 & 3.481 \\
\hline 6 & 792 & 468 & 506 & 324 & 104.976 & 286 & 81.796 & -38 & 1.444 \\
\hline & & & $\Sigma$ & 1473 & 380.977 & 1421 & 349.231 & -52 & 7.320 \\
\hline & & & $\mathrm{sd}^{2}$ & \multicolumn{2}{|c|}{$3.871,10$} & \multicolumn{2}{|c|}{$2.538,17$} & \multicolumn{2}{|c|}{$1.373,87$} \\
\hline & & & $\mathrm{sd}$ & \multicolumn{2}{|c|}{62,22} & \multicolumn{2}{|c|}{50,38} & \multicolumn{2}{|c|}{37,07} \\
\hline & & & $t_{5}$ & \multicolumn{2}{|c|}{9,67} & \multicolumn{2}{|c|}{11,51} & \multicolumn{2}{|c|}{$-0,57$} \\
\hline & & & $t_{5 ; 5 \%}$ & \multicolumn{6}{|c|}{2,57} \\
\hline
\end{tabular}

Portanto, conforme pode ser observado na tabela 5.14 e no gráfico 5.28, o tratamento térmico de revenimento reduziu, significativamente, não apenas a dureza na LCS de 730,8 $\pm 56,3 \mathrm{HV}$, para

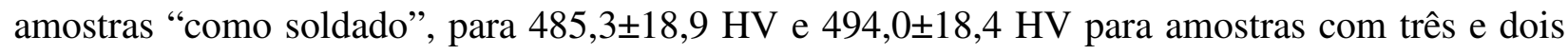
revenidos, respectivamente, como também os valores de dureza na ZAC.

\subsubsection{Variação da Dureza na LCS em Função da Temperatura de Revenido.}

Foram testadas três condições com relação à variação na temperatura de revenido após a soldagem: 
D1: Temperatura de revenido de $500^{\circ} \mathrm{C}$ x 14 s.

D2: Temperatura de revenido de $550^{\circ} \mathrm{C} \times 14 \mathrm{~s}$.

D3: Temperatura de revenido de $650^{\circ} \mathrm{C} \times 14 \mathrm{~s}$.

Os dados dos parâmetros D1, D2 e D3 estão relacionados na tabela "Planejamento dos corpos de prova para ensaios de soldagem em serras de fita bimetálica de $27 \mathrm{~mm}$ " do anexo 01.

A tabela 5.17 e o gráfico da figura 5.29 mostram os valores de dureza na LCS, na ZAC e no MB para os parâmetros D1, D2 e D3 testados.

Tabela 5.17 Variação da Dureza na LCS em Função da Variação da Temperatura de Revenido.

\begin{tabular}{|c|c|c|c|c|c|c|c|c|c|c|c|}
\hline \multicolumn{12}{|c|}{ Variação da Dureza (HV) x Temperatura de Revenido. } \\
\hline \multirow{3}{*}{$\begin{array}{c}\text { Parâmetro } \\
\text { D }\end{array}$} & \multicolumn{11}{|c|}{ Distância da Linha Central da Solda (mm) } \\
\hline & \multicolumn{2}{|c|}{$\mathrm{MB}$} & \multicolumn{3}{|c|}{$\mathrm{ZAC}$} & \multirow{2}{*}{$\begin{array}{c}\text { LCS } \\
0 \\
\end{array}$} & \multicolumn{3}{|c|}{$\mathrm{ZAC}$} & \multicolumn{2}{|c|}{$\mathrm{MB}$} \\
\hline & $-1,0$ & $-0,8$ & $-0,6$ & $-0,4$ & $-0,2$ & & 0,2 & 0,4 & 0,6 & 0,8 & 1,0 \\
\hline Média D1 & 505,0 & 503,0 & 540,3 & 551,5 & 530,3 & 508,3 & 527,5 & 524,8 & 550,8 & 499,3 & 486,7 \\
\hline$\sigma \mathrm{D} 1$ & 9,0 & 0,9 & 63,2 & 51,6 & 20,7 & 14,6 & 3,5 & 4,9 & 51,1 & 1,4 & 6,6 \\
\hline Média D2 & 497,0 & 501,8 & 504,8 & 544,0 & 549,3 & 517,0 & 514,3 & 528,0 & 510,5 & 499,3 & 495,7 \\
\hline$\sigma \mathrm{D} 2$ & 23,6 & 18,1 & 27,6 & 0,0 & 13,2 & 3,8 & 17,0 & 13,7 & 21,4 & 5,7 & 0,9 \\
\hline Média D3 & 487,0 & 499,2 & 520,8 & 513,0 & 504,7 & 494,8 & 531,2 & 533,2 & 539,3 & 484,3 & 484,3 \\
\hline$\sigma \mathrm{D} 3$ & 9,4 & 11,1 & 37,5 & 19,8 & 12,3 & 4,0 & 17,2 & 19,6 & 33,0 & 5,7 & 4,7 \\
\hline
\end{tabular}




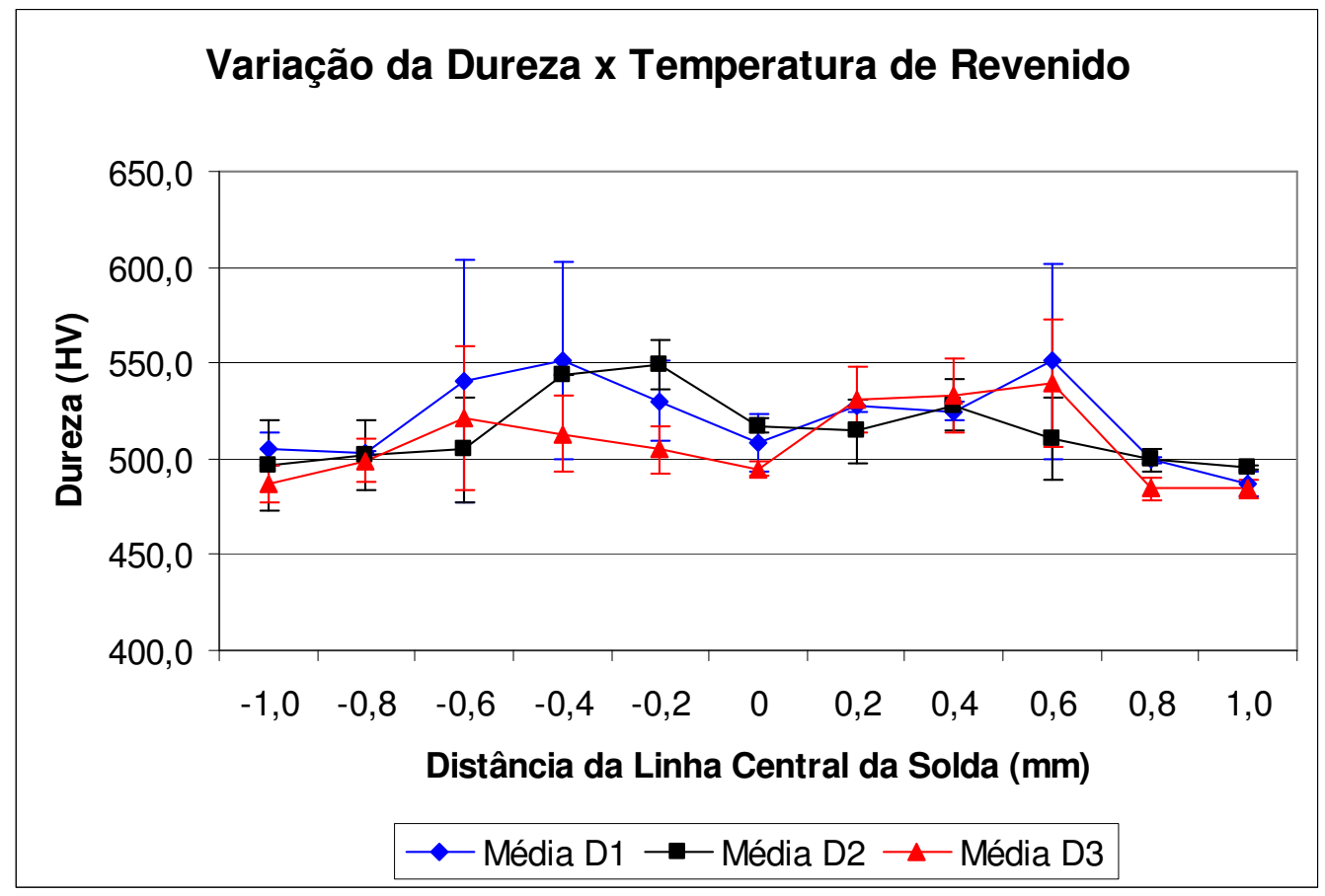

Figura 5.29 Variação da dureza na LCS em função da variação da temperatura de revenido para os parâmetros D1, D2 e D3. Sentido transversal à LCS.

Os valores médios de dureza na LCS, resultantes dos testes com os parâmetros D1, D2 e D3, foram verificados pela Análise de Variância $^{(62)}$ e Testes de Hipóteses ${ }^{(63)}$, considerando-se dados emparelhados, conforme tabelas 5.18 e 5.19 a seguir.

Conforme pode ser visto na tabela 5.18, o valor para $\mathrm{F}$ calculado de 0,59 é menor que o valor para $\mathrm{F}$ tabelado $\left(\mathrm{F}_{15 ; 5 \%}\right)$ de 3,68. Isto permite concluir ao nível de 5\% de significância, que as três médias de durezas dos parâmetros D1, D2 e D3 são iguais, e, desta forma, pode-se afirmar que a dureza na LCS não variou em função da variação da temperatura de revenido, mantido o tempo de 14 s constante. 
Tabela 5.18 Análise de variância para dureza na LCS dos parâmetros D1, D2 e D3.

\begin{tabular}{|c|c|c|c|c|c|c|c|c|c|}
\hline \multicolumn{10}{|c|}{ Análise de Variância para Parâmetro D } \\
\hline \multirow[t]{3}{*}{ Amostra } & \multicolumn{9}{|c|}{ Dureza na LCS (HV) } \\
\hline & \multicolumn{3}{|c|}{ D1 } & \multicolumn{3}{|c|}{ D2 } & \multicolumn{3}{|c|}{ D3 } \\
\hline & $\mathrm{x}_{\mathrm{ij}}$ & $\mathrm{x}_{\mathrm{ij}-490}$ & $\mathrm{x}_{\mathrm{ij}-490^{2}}$ & $x_{i j}$ & $\mathrm{x}_{\mathrm{ij}-490}$ & $x_{i j-490}{ }^{2}$ & $\mathrm{x}_{\mathrm{ij}}$ & $\mathrm{x}_{\mathrm{ij}-490}$ & $\mathrm{X}_{\mathrm{ij}-490^{2}}$ \\
\hline 1 & 508 & 18 & 324 & 539 & 49 & 2401 & 485 & -5 & 25 \\
\hline 2 & 506 & 16 & 256 & 498 & 8 & 64 & 498 & 8 & 64 \\
\hline 3 & 542 & 52 & 2704 & 522 & 32 & 1024 & 493 & 3 & 9 \\
\hline 4 & 452 & -38 & 1444 & 563 & 73 & 5329 & 483 & -7 & 49 \\
\hline 5 & 500 & 10 & 100 & 426 & -64 & 4096 & 488 & -2 & 4 \\
\hline 6 & 542 & 52 & 2704 & 554 & 64 & 4096 & 522 & 32 & 1024 \\
\hline Média & 508,3 & - & - & 517,0 & - & - & 494,8 & - & - \\
\hline$\sigma$ & 33,2 & - & - & 50,3 & - & - & 14,4 & - & - \\
\hline \multicolumn{2}{|c|}{ Fonte de Variação } & \multicolumn{2}{|c|}{$\begin{array}{c}\text { Soma de } \\
\text { Quadrados }\end{array}$} & \multicolumn{2}{|c|}{$\begin{array}{c}\text { Graus de } \\
\text { Liberdade }\end{array}$} & \multicolumn{2}{|c|}{$\begin{array}{l}\text { Quadrado } \\
\text { Médio }\end{array}$} & $\mathrm{F}$ & $\mathrm{F}_{\alpha}$ \\
\hline \multicolumn{2}{|c|}{ Entre Amostras } & \multicolumn{2}{|c|}{$1.497,44$} & \multicolumn{2}{|c|}{2} & \multicolumn{2}{|c|}{748,72} & 0,59 & $\mathrm{~F}_{15 ; 5 \%}=3,68$ \\
\hline \multicolumn{2}{|c|}{ Residual } & \multicolumn{2}{|c|}{$19.186,17$} & \multicolumn{2}{|c|}{15} & \multicolumn{2}{|c|}{$1.279,08$} & & \\
\hline \multicolumn{2}{|c|}{ Total } & \multicolumn{2}{|c|}{$20.683,61$} & \multicolumn{2}{|c|}{17} & & & & \\
\hline
\end{tabular}

Tabela 5.19 Testes de hipóteses para dureza na LCS dos parâmetros D1, D2 e D3.

\begin{tabular}{|c|c|c|c|c|c|c|c|c|c|}
\hline \multicolumn{10}{|c|}{ Testes de Hipótese para Parâmetro D } \\
\hline \multirow[t]{2}{*}{ Amostra } & \multicolumn{3}{|c|}{$\begin{array}{c}\text { Dureza na LCS } \\
(\mathrm{HV})\end{array}$} & \multicolumn{2}{|c|}{ D1 x D2 } & \multicolumn{2}{|c|}{ D1 x D3 } & \multicolumn{2}{|c|}{ D2 x D3 } \\
\hline & D1 & D2 & D3 & $\mathrm{d}_{\mathrm{A} 1 \mathrm{~A} 2}$ & $\mathrm{~d}_{\mathrm{A} 1 \mathrm{~A} 2}{ }^{2}$ & $\mathrm{~d}_{\mathrm{A} 1 \mathrm{~A} 3}$ & $\mathrm{~d}_{\mathrm{A} 1 \mathrm{~A} 3^{2}}$ & $\mathrm{~d}_{\mathrm{A} 2 \mathrm{~A} 3}$ & $\mathrm{~d}_{\mathrm{A} 2 \mathrm{~A} 3^{2}}$ \\
\hline 1 & 508 & 539 & 485 & -31 & 961 & 23 & 529 & 54 & 2.916 \\
\hline 2 & 506 & 498 & 498 & 8 & 64 & 8 & 64 & 0 & 0 \\
\hline 3 & 542 & 522 & 493 & 20 & 400 & 49 & 2.401 & 29 & 841 \\
\hline 4 & 452 & 563 & 483 & -111 & 12.321 & -31 & 961 & 80 & 6.400 \\
\hline 5 & 500 & 426 & 488 & 74 & 5.476 & 12 & 144 & -62 & 3.844 \\
\hline 6 & 542 & 554 & 522 & -12 & 144 & 20 & 400 & 32 & 1.024 \\
\hline & & & $\Sigma$ & -52 & 19.366 & 81 & 4.499 & 133 & 15.025 \\
\hline & & & $\mathrm{sd}^{2}$ & \multicolumn{2}{|c|}{$3.783,07$} & \multicolumn{2}{|c|}{681,10} & \multicolumn{2}{|c|}{$2.415,37$} \\
\hline & & & $\mathrm{sd}$ & \multicolumn{2}{|c|}{61,51} & \multicolumn{2}{|c|}{26,10} & \multicolumn{2}{|c|}{49,15} \\
\hline & & & $\mathrm{t}_{5}$ & \multicolumn{2}{|c|}{$-0,35$} & & & \multicolumn{2}{|c|}{1,10} \\
\hline & & & $t_{5: 5 \%}$ & \multicolumn{6}{|c|}{2,57} \\
\hline
\end{tabular}

Da mesma forma, conforme mostrado na tabela 5.19, os valores para $t$ calculado $\left(\mathrm{t}_{5}\right)$ de $-0,35$ para a comparação das médias $\mathrm{D} 1 x \mathrm{x} 2,1,27$ para a comparação das médias $\mathrm{D} 1 x \mathrm{x} 3$ e 1,10 para a 
comparação das médias D2xD3 são menores em módulo que o valor para t tabelado $\left(\mathrm{t}_{5 ; 5 \%}\right)$ de 2,57. Isto permite concluir, ao nível de 5\% de significância, que o valor médio de dureza na LCS para os parâmetros D1, D2 e D3 são iguais.

Portanto, conforme pode ser observado na tabela 5.17 e no gráfico 5.29, a temperatura de revenimento de $650^{\circ} \mathrm{C}$ resultou na menor dureza na LCS $(494,8 \pm 4,0 \mathrm{HV})$ para amostras com um revenimento a $14 \mathrm{~s}$, em relação às temperatura de $500^{\circ}$ e $550^{\circ}$, o que está de acordo com a literatura ${ }^{(29,37)}$.

\subsubsection{Variação da Dureza na LCS em Função do Tempo de Revenido.}

Foram testadas três condições com relação à variação no tempo de revenido após a soldagem:

E1: Tempo de revenido de $6 \mathrm{~s} \times 650^{\circ} \mathrm{C}$.

E2: Tempo de revenido de $10 \mathrm{~s} \times 650^{\circ} \mathrm{C}$.

E3: Tempo de revenido de $18 \mathrm{~s} \times 650^{\circ} \mathrm{C}$.

Os dados dos parâmetros E1, E2 e E3 estão relacionados na tabela "Planejamento dos corpos de prova para ensaios de soldagem em serras de fita bimetálica de $27 \mathrm{~mm}$ ” do anexo 01 .

A tabela 5.20 e o gráfico da figura 5.30 mostram os valores de dureza na LCS, na ZAC e no MB para os parâmetros E1, E2 e E3 testados. 
Tabela 5.20 Variação da Dureza na LCS em Função da Variação do Tempo de Revenido.

\begin{tabular}{|c|c|c|c|c|c|c|c|c|c|c|c|}
\hline \multicolumn{12}{|c|}{ Variação da Dureza (HV) x Tempo de Revenido. } \\
\hline \multirow{3}{*}{$\begin{array}{c}\text { Parâmetro } \\
\text { E }\end{array}$} & \multicolumn{11}{|c|}{ Distância da Linha Central da Solda (mm) } \\
\hline & \multicolumn{2}{|c|}{ MB } & \multicolumn{3}{|c|}{ ZAC } & \multirow{2}{*}{$\begin{array}{c}\text { LCS } \\
0\end{array}$} & \multicolumn{3}{|c|}{ ZAC } & \multicolumn{2}{|c|}{ MB } \\
\hline & $-1,0$ & $-0,8$ & $-0,6$ & $-0,4$ & $-0,2$ & & 0,2 & 0,4 & 0,6 & 0,8 & 1,0 \\
\hline Média E1 & 473,5 & 475,2 & 507,8 & 509,8 & 502,5 & 490,0 & 506,0 & 508,7 & 513,2 & 482,3 & 482,0 \\
\hline$\sigma \mathrm{E} 1$ & 4,0 & 0,7 & 16,3 & 17,7 & 16,3 & 0,5 & 5,7 & 16,0 & 11,1 & 0,5 & 8,0 \\
\hline Média E2 & 476,5 & 485,5 & 516,8 & 508,5 & 502,0 & 492,2 & 503,3 & 517,3 & 517,0 & 485,0 & 483,7 \\
\hline$\sigma \mathrm{E} 2$ & 15,8 & 29,9 & 2,6 & 7,3 & 1,9 & 9,7 & 6,1 & 11,8 & 22,2 & 10,8 & 3,3 \\
\hline Média E3 & 450,5 & 514,0 & 516,3 & 511,5 & 523,3 & 470,0 & 516,7 & 502,5 & 498,0 & 459,5 & 465,0 \\
\hline$\sigma \mathrm{E} 3$ & 20,5 & 25,5 & 28,3 & 22,9 & 3,3 & 12,3 & 20,3 & 2,1 & 9,4 & 5,9 & 1,4 \\
\hline
\end{tabular}

Os valores médios de dureza na LCS, resultantes dos testes com os parâmetros E1, E2 e E3, foram verificados pela Análise de Variância $^{(62)}$ e Testes de Hipóteses ${ }^{(63)}$, considerando-se dados emparelhados, conforme tabelas 5.21 e 5.22 a seguir.

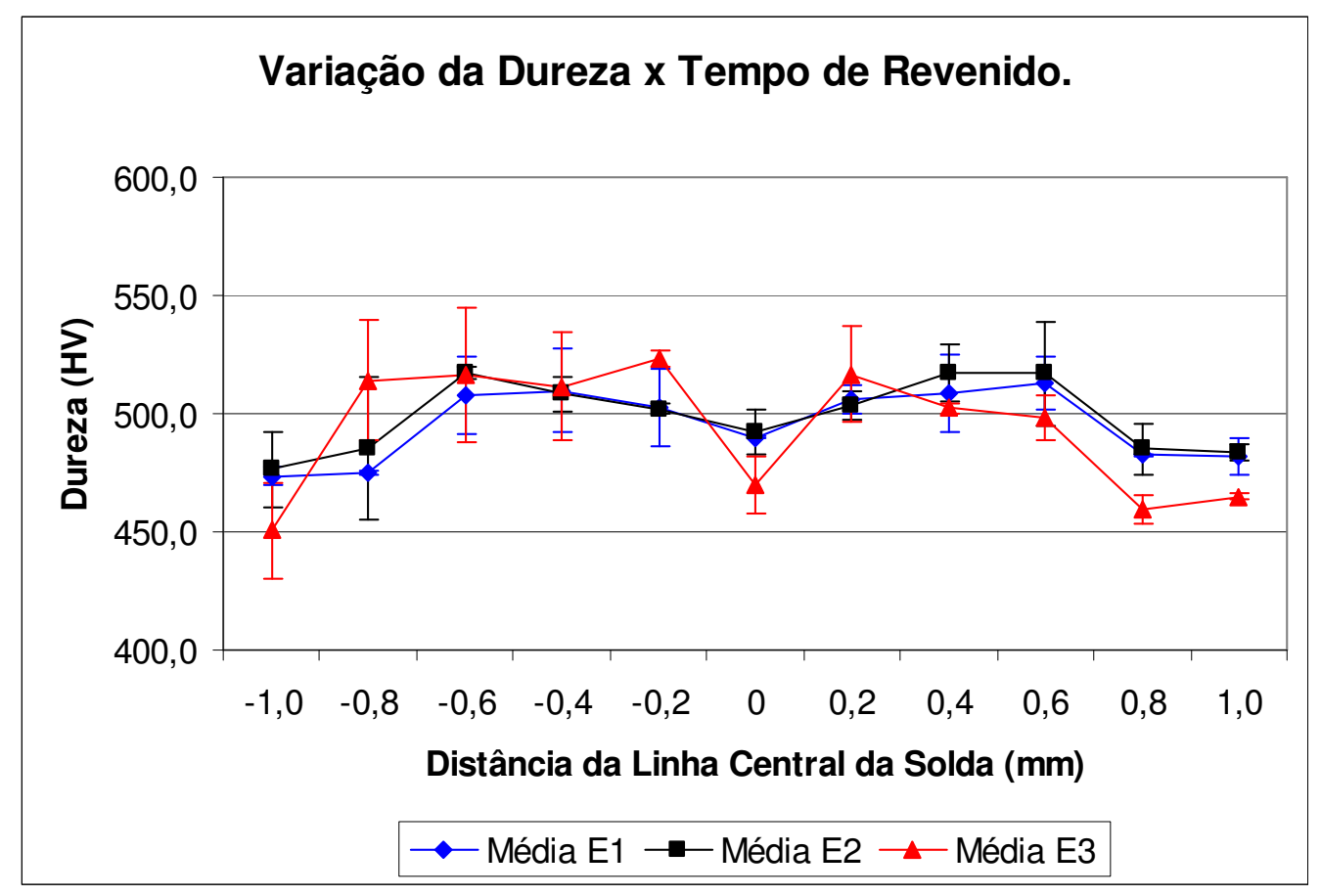

Figura 5.30 Variação da dureza na LCS em função da variação do tempo de revenido para os parâmetros E1, E2 e E3. Sentido transversal à LCS. 
Conforme pode ser visto na tabela 5.21, o valor para $\mathrm{F}$ calculado de 1,55 é menor que o valor para $\mathrm{F}$ tabelado $\left(\mathrm{F}_{15 ; 5 \%}\right)$ de 3,68. Isto permite concluir ao nível de 5\% de significância, que as três médias de durezas dos parâmetros E1, E2 e E3 são iguais, e, desta forma, pode-se afirmar que a dureza na LCS não variou em função da variação do tempo de revenido, mantida a temperatura de $650^{\circ} \mathrm{C}$ constante.

Tabela 5.21 Análise de variância para dureza na LCS dos parâmetros E1, E2 e E3.

\begin{tabular}{|c|c|c|c|c|c|c|c|c|c|}
\hline \multicolumn{10}{|c|}{ Análise de Variância para Parâmetro E } \\
\hline \multirow[t]{3}{*}{ Amostra } & \multicolumn{9}{|c|}{ Dureza na LCS (HV) } \\
\hline & \multicolumn{3}{|c|}{ E1 } & \multicolumn{3}{|c|}{ E2 } & \multicolumn{3}{|c|}{ E3 } \\
\hline & $\mathrm{x}_{\mathrm{ij}}$ & $\mathrm{x}_{\mathrm{ij}-490}$ & $\mathrm{x}_{\mathrm{ij}-490^{2}}$ & $\mathrm{x}_{\mathrm{ij}}$ & $\mathrm{X}_{\mathrm{ij}-490}$ & $\mathrm{x}_{\mathrm{ij}-490^{2}}^{2}$ & $\mathrm{x}_{\mathrm{ij}}$ & $\mathrm{x}_{\mathrm{ij}-490}$ & $\mathrm{x}_{\mathrm{ij}-490^{2}}^{2}$ \\
\hline 1 & 493 & 3 & 9 & 483 & -7 & 49 & 448 & -42 & 1764 \\
\hline 2 & 480 & -10 & 100 & 475 & -15 & 225 & 452 & -38 & 1444 \\
\hline 3 & 498 & 8 & 64 & 539 & 49 & 2401 & 536 & 46 & 2116 \\
\hline 4 & 488 & -2 & 4 & 478 & -12 & 144 & 473 & -17 & 289 \\
\hline 5 & 483 & -7 & 49 & 488 & -2 & 4 & 457 & -33 & 1089 \\
\hline 6 & 498 & 8 & 64 & 490 & 0 & 0 & 454 & -36 & 1296 \\
\hline Média & 490,0 & - & - & 492,2 & - & - & 470,0 & - & - \\
\hline$\sigma$ & 7,6 & - & - & 23,6 & - & - & 33,5 & - & - \\
\hline \multicolumn{2}{|c|}{ Fonte de Variação } & \multicolumn{2}{|c|}{$\begin{array}{c}\text { Soma de } \\
\text { Quadrados }\end{array}$} & \multicolumn{2}{|c|}{$\begin{array}{c}\text { Graus de } \\
\text { Liberdade }\end{array}$} & \multicolumn{2}{|c|}{$\begin{array}{c}\text { Quadrado } \\
\text { Médio } \\
\end{array}$} & $\mathrm{F}$ & $\mathrm{F}_{\alpha}$ \\
\hline \multicolumn{2}{|c|}{ Entre Amostras } & \multicolumn{2}{|c|}{$1.792,11$} & \multicolumn{2}{|c|}{2} & \multicolumn{2}{|c|}{896,06} & 1,55 & $F_{15 ; 5 \%}=3,68$ \\
\hline \multicolumn{2}{|c|}{ Residual } & \multicolumn{2}{|c|}{$8.682,83$} & \multicolumn{2}{|c|}{15} & \multicolumn{2}{|c|}{578,86} & & \\
\hline \multicolumn{2}{|c|}{ Total } & \multicolumn{2}{|c|}{$10.474,94$} & \multicolumn{2}{|c|}{17} & & & & \\
\hline
\end{tabular}

Do mesmo modo, conforme mostrado na tabela 5.22, os valores para $t$ calculado $\left(\mathrm{t}_{5}\right)$ de $-0,27$ para a comparação das médias E1xE2 e de 1,60 para a comparação das médias E1xE3 são menores em módulo que o valor para $\mathrm{t}$ tabelado $\left(\mathrm{t}_{5 ; 5 \%}\right)$ de 2,57, e o valor para t calculado $\left(\mathrm{t}_{5}\right)$ de 3,67 para a comparação das médias E2xE3 é maior que o valor para t tabelado $\left(t_{5 ; 5 \%}\right)$ de 2,57. Isto permite 
concluir, ao nível de 5\% de significância, que o valor médio de dureza na LCS para o parâmetro E1 é igual aos respectivos valores para os parâmetros E2 e E3, devido ao desvio padrão de E3, e que os valores de dureza na LCS para os parâmetros E2 e E3 são diferentes.

Tabela 5.22 Testes de hipóteses para dureza na LCS dos parâmetros E1, E2 e E3.

\begin{tabular}{|c|c|c|c|c|c|c|c|c|c|}
\hline \multicolumn{10}{|c|}{ Teste de Hipótese para Parâmetro E } \\
\hline \multirow[t]{2}{*}{ Amostra } & \multicolumn{3}{|c|}{ Dureza na LCS (HV) } & \multicolumn{2}{|c|}{$\mathrm{E} 1 \times \mathrm{E} 2$} & \multicolumn{2}{|c|}{ E1 $x$ E3 } & \multicolumn{2}{|c|}{ E2 $\times$ E3 } \\
\hline & E1 & E2 & E3 & $d_{A 1 A 2}$ & $d_{A 1 A 2}{ }^{2}$ & $d_{\mathrm{A} 1 \mathrm{~A} 3}$ & $d_{A 1 A 3}{ }^{2}$ & $d_{A 2 A 3}$ & $d_{A 2 A 3^{2}}$ \\
\hline 1 & 493 & 483 & 448 & 10 & 100 & 45 & 2.025 & 35 & 1.225 \\
\hline 2 & 480 & 475 & 452 & 5 & 25 & 28 & 784 & 23 & 529 \\
\hline 3 & 498 & 539 & 536 & -41 & 1.681 & -38 & 1.444 & 3 & 9 \\
\hline 4 & 488 & 478 & 473 & 10 & 100 & 15 & 225 & 5 & 25 \\
\hline 5 & 483 & 488 & 457 & -5 & 25 & 26 & 676 & 31 & 961 \\
\hline 6 & 498 & 490 & 454 & 8 & 64 & 44 & 1.936 & 36 & 1.296 \\
\hline & & & $\Sigma$ & -13 & 1.995 & 120 & 7.090 & 133 & 4.045 \\
\hline & & & $s d^{2}$ & \multicolumn{2}{|c|}{393,37} & \multicolumn{2}{|c|}{938,00} & \multicolumn{2}{|c|}{219,37} \\
\hline & & & $s d$ & \multicolumn{2}{|c|}{19,83} & \multicolumn{2}{|c|}{30,63} & \multicolumn{2}{|c|}{14,81} \\
\hline & & & $t_{5}$ & \multicolumn{2}{|c|}{$-0,27$} & & & \multicolumn{2}{|c|}{3,67} \\
\hline & & & $t_{5 ; 5 \%}$ & \multicolumn{6}{|c|}{2,57} \\
\hline
\end{tabular}

Portanto, conforme pode ser observado na tabela 5.20 e no gráfico 5.30, o tempo de revenido de 18s resultou na menor dureza na LCS $(470,0 \pm 12,3) \mathrm{HV}$ para amostras com um revenimento a 650s, em relação aos tempos de revenidos de 6 s e 10 s, o que está em acordo com a literatura ${ }^{(37)}$.

\subsubsection{Verificação da Dureza nas Regiões de Micro-segregação.}

As regiões de micro-segregação são as linhas claras e escuras observadas nas análises metalográficas da seção transversal à LCS, conforme pode ser observado nas figuras 5.11 e 5.12. A deformação, juntamente com a alta temperatura de soldagem, provoca o alongamento dos grãos na direção contrária às linhas de fluxo de laminação, e isto faz aumentar a dureza da ZAC 
próximo à LCS. A taxa de deformação depende do valor da pressão de recalque. Foi verificado na região da ZAC que as linhas curvas de cor escuras têm dureza maior que a das linhas curvas de cor mais claras na seção transversal à LCS. As durezas foram medidas sobre as regiões claras e escuras mantendo-se um eixo paralelo à LCS, porém variando-se a distância desta linha em relação à LCS. Os resultados destas medições de dureza estão relacionados na tabela 5.23.

Tabela 5.23 Relação de durezas das linhas claras x linhas escuras da ZAC.

\begin{tabular}{|c|c|c|c|c|}
\hline \multirow{5}{*}{ Distância da LCS } & \multicolumn{2}{|c|}{ Amostra A1T2 } & \multicolumn{2}{c|}{ Amostra A3T2 } \\
\cline { 2 - 5 } & Linha Clara (LC) & Linha Escura (LE) & Linha Clara (LC) & Linha Escura (LE) \\
mm & HV & HV & HV & HV \\
\hline 0,2 & 495,2 & 595,2 & 510,9 & 591,9 \\
\hline 0,2 & 485,1 & 553,7 & 500,4 & 572,3 \\
\hline 0,2 & 480,2 & 544,7 & 492,7 & 536,0 \\
\hline 0,4 & 490,1 & 538,9 & 492,7 & 533,1 \\
\hline 0,4 & 490,1 & 533,1 & 465,9 & 527,4 \\
\hline 0,4 & 495,2 & 510,9 & 473,0 & 540,2 \\
\hline Média & $489,3 \pm 7,6$ & $546,1 \pm 26,9$ & $489,3 \pm 9,1$ & $550,2 \pm 28,4$ \\
\hline Relação LE/LC $(\%)$ & - & 11,60 & - & 12,44 \\
\hline
\end{tabular}

Conforme pode ser visto na tabela 5.23 as linhas escuras apresentaram uma dureza de aproximadamente $12 \%$ maior em relação às linhas claras. O mesmo se aplica em relação às linhas claras e escuras das partes onde as linhas de fluxo não foram deformadas, incluindo ZAC e MB, próximo à interface com a ZAC, porém os valores das durezas foram tornando-se reduzidos, conforme se aumentava a distância em relação à LCS, em função do gradiente de temperatura ser menor na direção do metal de base. 


\subsubsection{Verificação da Composição Química por EDS nas Regiões de Micro-segregação.}

Foram feitas análises por EDS nas linhas de fluxo das regiões claras e escuras da ZAC, com o objetivo de determinar os teores de elementos de liga micro-segregados nestas regiões. Os pontos das regiões analisadas foram determinados conforme indicado na figura 5.31 a seguir.

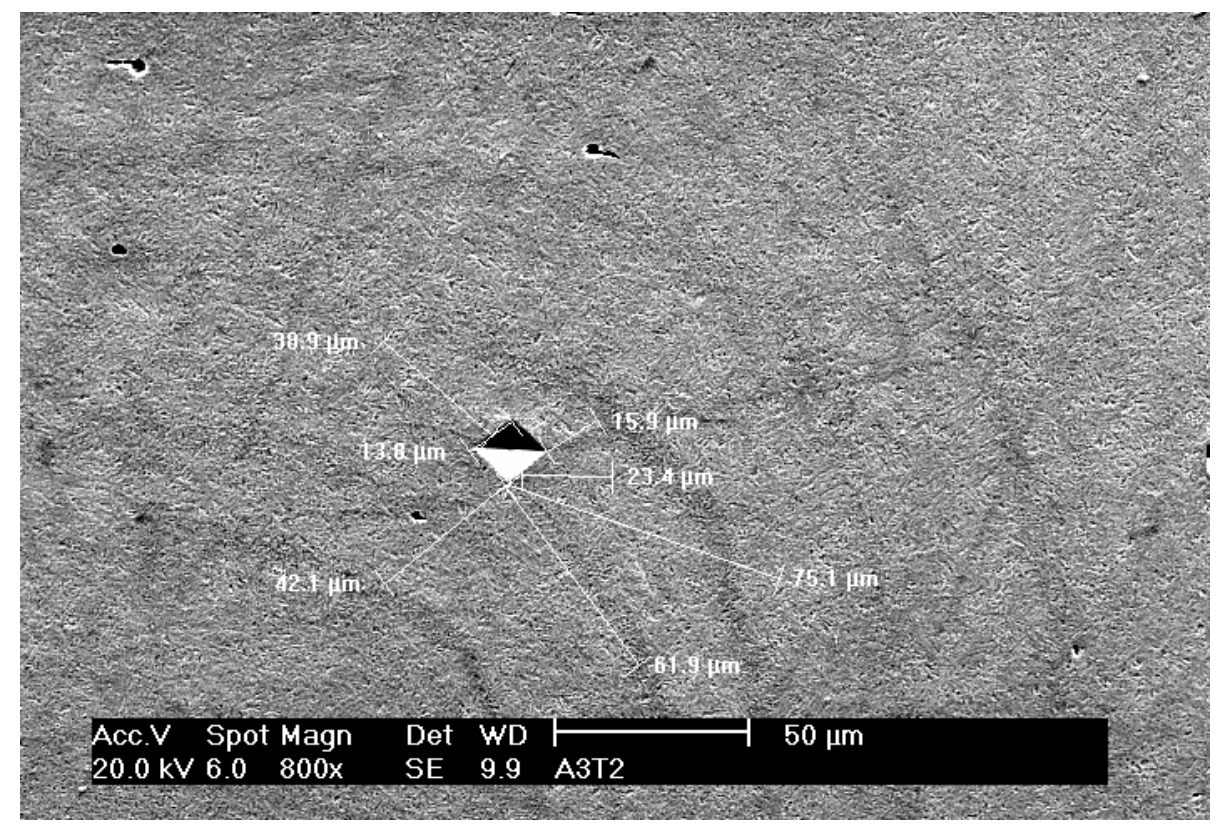

Figura 5.31 Determinação dos pontos sobre as linhas de fluxo claras e escuras da ZAC para execução da análise por EDS. Sentido transversal à LCS. Amostra A3T2. MEV. 800X.

Os resultados das análises por EDS das linhas claras e escuras da ZAC para as amostras A2T2 e A3T2 estão indicados na tabela 5.24, bem como uma comparação com o MB de uma região próxima à interface com a ZAC. Foi considerada a média de seis análises químicas por EDS, sendo três para cada uma das amostras citadas, para a determinação das frações em peso e atômica dos elementos de liga, conforme tabela 5.24. 
Tabela 5.24 Análise EDS nas linhas de fluxo da ZAC e MB das amostras A2T2 e A3T2.

\begin{tabular}{|c|c|c|c|c|c|c|c|c|c|}
\hline \multicolumn{10}{|c|}{ Análise EDS nas linhas de fluxo da ZAC e MB das amostras A2T2 e A3T2. } \\
\hline \multirow[t]{3}{*}{ Elementos } & \multirow{2}{*}{\multicolumn{2}{|c|}{$\begin{array}{c}\text { Linhas Claras (LC) } \\
*^{*} \text { Média }\end{array}$}} & \multirow{2}{*}{\multicolumn{2}{|c|}{$\frac{\text { Linhas Escuras (LE) }}{* \text { Média }}$}} & \multirow{3}{*}{$\begin{array}{c}* * \text { Relação } \\
\text { LE/LC } \\
- \\
\end{array}$} & \multirow{2}{*}{\multicolumn{2}{|c|}{$\frac{\text { MB }}{\text { *Média }}$}} & \multirow{3}{*}{$\begin{array}{c}\text { **Relaçãa } \\
\text { LE/MB } \\
- \\
\end{array}$} & \multirow{3}{*}{$\begin{array}{c}* * \text { Relação } \\
\text { LC/MB } \\
- \\
\end{array}$} \\
\hline & & & & & & & & & \\
\hline & $\% \mathrm{p}$ & $\%$ at & $\% \mathrm{p}$ & $\%$ at & & $\% \mathrm{p}$ & $\%$ at & & \\
\hline $\mathrm{Si}$ & 0,37 & 0,73 & 0,37 & 0,73 & 1,00 & 0,35 & 0,70 & 1,04 & 1,04 \\
\hline Mo & 0,99 & 0,57 & 1,41 & 0,82 & 1,44 & 0,98 & 0,57 & 1,44 & 1,00 \\
\hline $\mathrm{Cr}$ & 1,16 & 1,25 & 1,37 & 1,47 & 1,18 & 1,14 & 1,23 & 1,20 & 1,02 \\
\hline $\mathrm{Mn}$ & 0,95 & 0,96 & 1,12 & 1,13 & 1,18 & 0,94 & 0,96 & 1,18 & 1,00 \\
\hline $\mathrm{Fe}$ & 95,90 & 95,90 & 95,10 & 95,20 & 0,99 & 96,12 & 96,10 & 0,99 & 1,00 \\
\hline $\mathrm{Ni}$ & 0,65 & 0,62 & 0,69 & 0,66 & 1,06 & 0,47 & 0,45 & 1,47 & 1,38 \\
\hline
\end{tabular}

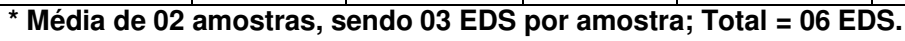

${ }^{\star *}$ Em \%at.

Como pode ser visto na tabela 5.24, as linhas de fluxo escuras são mais ricas em elementos de liga em relação às linhas claras, principalmente com relação ao molibdênio, cromo e manganês. Este fato pode justificar a diferença de dureza entre as duas regiões, uma vez que estes elementos também fazem a dureza aumentar ${ }^{(65)}$. Quando comparadas com o metal de base de uma região próximo à interface com a ZAC, as linhas escuras apresentaram teores bem mais elevados de molibdênio, cromo, manganês e níquel, enquanto que as linhas claras apresentam uma relativa similaridade, tendo apenas o níquel com teor mais elevado.

\subsubsection{Verificação da Composição Química por EDS na LCS.}

Os resultados das análises por EDS da LCS para as amostras A2T2 e A3T2 estão indicados na tabela 5.25, bem como uma comparação com o MB de uma região próxima à interface com a ZAC. Foi considerada a média de seis análises EDS, sendo três para cada uma das amostras citadas, para a determinação das frações em peso e atômica dos elementos de liga, conforme tabela 5.25. 
Tabela 5.25 Análise EDS na LCS e MB das amostras A2T2 e A3T2.

\begin{tabular}{|c|c|c|c|c|c|}
\hline \multicolumn{6}{|c|}{ Análise EDS na LCS e MB das amostras A2T2 e A3T2. } \\
\hline \multirow{3}{*}{ Elementos } & \multirow{2}{*}{\multicolumn{2}{|c|}{$\frac{\text { LCS }}{\text { *Média }}$}} & \multirow{2}{*}{\multicolumn{2}{|c|}{$\begin{array}{c}\text { MB } \\
\text { *Média }\end{array}$}} & \multirow{3}{*}{$\begin{array}{c}\text { **Relação } \\
\text { LCS/MB } \\
- \\
\end{array}$} \\
\hline & & & & & \\
\hline & $\% \mathrm{p}$ & $\%$ at & $\% \mathrm{p}$ & $\%$ at & \\
\hline $\mathrm{Si}$ & 0,35 & 0,71 & 0,35 & 0,70 & 1,01 \\
\hline Mo & 1,11 & 0,65 & 0,98 & 0,57 & 1,14 \\
\hline $\mathrm{Cr}$ & 1,22 & 1,31 & 1,14 & 1,23 & 1,07 \\
\hline $\mathrm{Mn}$ & 0,99 & 1,01 & 0,94 & 0,96 & 1,05 \\
\hline $\mathrm{Fe}$ & 95,82 & 95,85 & 96,12 & 96,10 & 1,00 \\
\hline $\mathrm{Ni}$ & 0,52 & 0,50 & 0,47 & 0,45 & 1,11 \\
\hline
\end{tabular}

Conforme pode ser visto na tabela 5.25, os teores dos elementos de liga da LCS são levemente superiores aos respectivos teores do metal de base de uma região próxima à interface com a ZAC, com exceção dos teores de molibdênio e níquel, que são bem mais elevados em relação ao metal de base.

Este maior teor dos elementos de liga molibdênio e níquel na LCS não foram suficientes para alterar sua dureza ${ }^{(65)}$ em relação ao $\mathrm{MB}$, o que faz com que a dureza na LCS seja aproximadamente igual à dureza no MB de regiões próximas à interface com a ZAC, conforme já visto anteriormente nos gráficos dos itens 5.2.3.1 a 5.2.3.5.

\subsubsection{Verificação da dureza na região de austenita retida.}

Conforme visto anteriormente nas tabelas 5.1 e 5.3, algumas amostras apresentaram austenita retida em sua microestrutura. Foram verificadas as durezas da austenita retida das amostras D1L1 e D1T1, com cargas de 50g e 100g, respectivamente. Os resultados encontram-se relacionados na tabela 5.26. 
Tabela 5.26 Verificação de microdureza na austenita retida da amostra D1L1 e D1T1.

\begin{tabular}{|c|c|c|}
\hline \multicolumn{3}{|c|}{ Medição de Microdureza na Austenita Retida } \\
\hline \multirow{3}{*}{ Pontos de Medição } & \multicolumn{2}{|c|}{ Amostra No (carga de teste) } \\
\cline { 2 - 3 } & D1L1 (50g) & D1T1 (100g) \\
\cline { 2 - 3 } & HV & HV \\
\hline 1 & 685,2 & 665,9 \\
\hline 2 & 634,0 & 719,7 \\
\hline 3 & 728,9 & 713,4 \\
\hline Média & $682,7 \pm 47,5$ & $699,7 \pm 29,4$ \\
\hline
\end{tabular}

A figura 5.32 mostra a medição da microdureza na austenita retida da amostra D1L1.

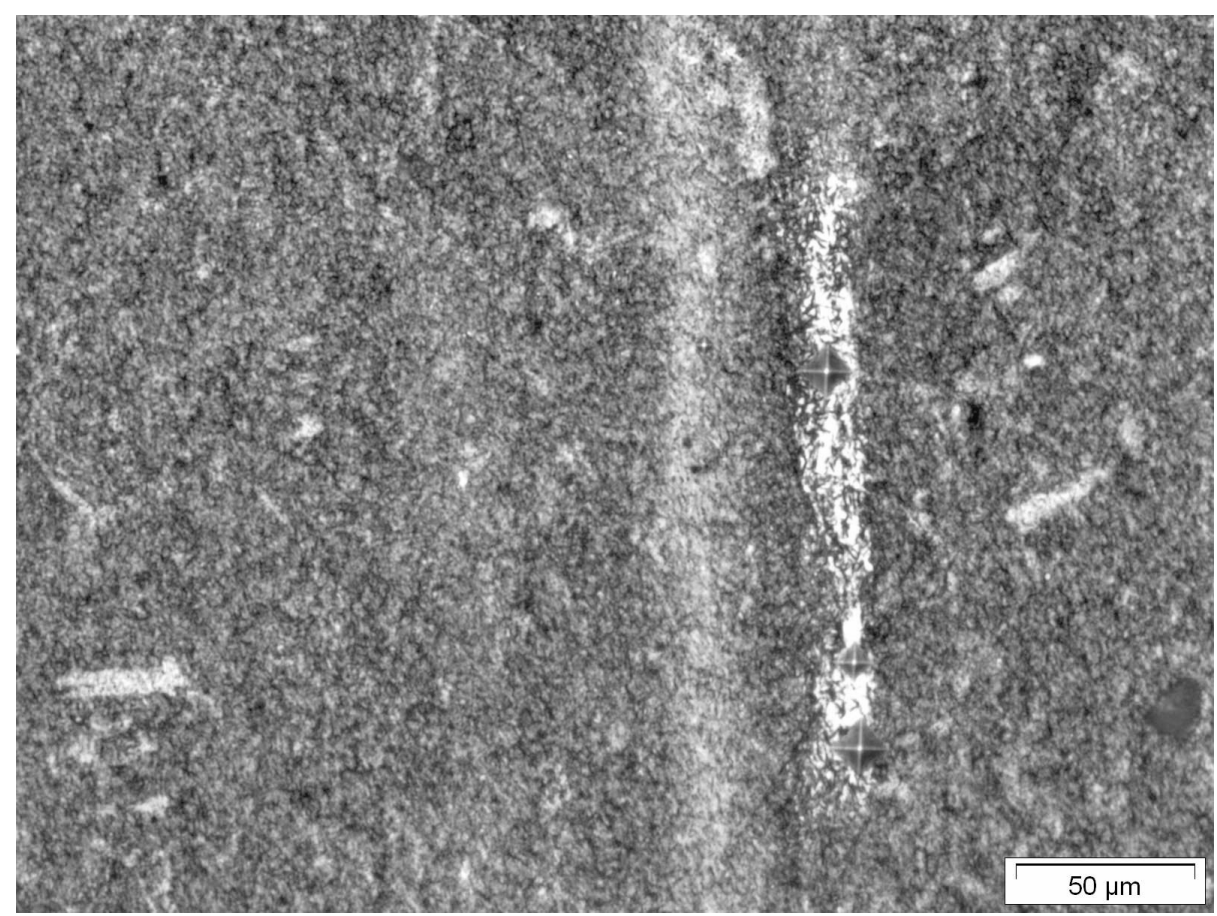

Figura 5.32 Medição de microdureza na austenita retida da amostra D1L1 com carga de 50g. MO. Ataque: Villela. 200X.

A dureza elevada da austenita retida nestas amostras pode ser atribuída à presença de martensita virgem, que é uma outra fase existente nesta região. Caso contrário, a dureza da austenita retida deveria ser de aproximadamente $300 \mathrm{HV}$. 


\subsubsection{Verificação da dureza na ZAC e MB em relação à LCS.}

Foram determinadas as durezas na ZAC e no MB próximo à interface com a ZAC, para ser feita uma comparação com as durezas da LCS. A tabela 5.27 mostra a comparação de durezas na ZAC e MB em relação à LCS.

Tabela 5.27 Comparação de durezas na ZAC e MB em relação à LCS.

\begin{tabular}{|c|c|c|c|c|c|c|c|}
\hline \multirow[t]{3}{*}{ Parâmetro } & \multirow[t]{2}{*}{ LCS } & \multicolumn{3}{|c|}{ ZAC } & \multicolumn{3}{|c|}{ MB } \\
\hline & & ZAC - ESQ & ZAC - DIR & MÉDIA & MB - ESQ & MB - DIR & MÉDIA \\
\hline & $\mathrm{HV}$ & $\mathrm{HV}$ & $\mathrm{HV}$ & $\mathrm{HV}$ & $\mathrm{HV}$ & $\mathrm{HV}$ & $\mathrm{HV}$ \\
\hline $\mathrm{A} 1$ & 472,2 & 512,6 & 494,3 & 503,5 & 480,65 & 485 & 482,8 \\
\hline $\mathrm{A} 2$ & 485,3 & 517,7 & 517,7 & 517,7 & 491 & 493,5 & 492,3 \\
\hline $\mathrm{A} 3$ & 525,7 & 521,3 & 513,7 & 517,5 & 488,15 & 482,75 & 485,5 \\
\hline Média A & $494,4 \pm 27,9$ & $517,2 \pm 4,4$ & $508,6 \pm 12,5$ & $512,9 \pm 8,1$ & $486,6 \pm 5,3$ & $487,1 \pm 5,7$ & $486,9 \pm 4,9$ \\
\hline Relação com LCS & 1,00 & 1,05 & 1,03 & 1,04 & 0,98 & 0,99 & 0,98 \\
\hline B1 & 459,2 & 483,9 & 479 & 481,5 & 472,2 & 489,8 & 481 \\
\hline B2 & 485,3 & 517,7 & 517,7 & 517,7 & 491 & 493,5 & 492,3 \\
\hline B3 & 502,7 & 497,8 & 509,4 & 503,6 & 459 & 481,85 & 470,4 \\
\hline Média B & $482,4 \pm 21,9$ & $499,8 \pm 17,0$ & $502,0 \pm 20,4$ & $500,9 \pm 18,2$ & $474,1 \pm 16,1$ & $488,4 \pm 6,0$ & $481,2 \pm 11,0$ \\
\hline Relação com LCS & 1,00 & 1,04 & 1,04 & 1,04 & 0,98 & 1,01 & 1,00 \\
\hline $\mathrm{C} 2$ & 485,3 & 517,7 & 517,7 & 517,7 & 491 & 493,5 & 492,3 \\
\hline $\mathrm{C} 3$ & 494 & 502,4 & 496,9 & 499,7 & 485,95 & 464,6 & 475,3 \\
\hline Média C & $489,7 \pm 6,2$ & $510,1 \pm 10,8$ & $507,3 \pm 14,7$ & $508,7 \pm 12,7$ & $488,5 \pm 3,6$ & $479,1 \pm 20,4$ & $483,8 \pm 12,0$ \\
\hline Relação com LCS & 1,00 & 1,04 & 1,04 & 1,04 & 1,00 & 0,98 & 0,99 \\
\hline D1 & 508,3 & 540,7 & 534,4 & 537,5 & 504 & 493 & 498,5 \\
\hline D2 & 517 & 532,7 & 517,6 & 525,2 & 499,4 & 497,5 & 498,5 \\
\hline D3 & 494,8 & 512,8 & 534,6 & 523,7 & 493,1 & 484,3 & 488,7 \\
\hline Média D & $506,7 \pm 11,2$ & $528,7 \pm 14,4$ & $528,9 \pm 9,8$ & $528,8 \pm 7,6$ & $498,8 \pm 5,5$ & $491,6 \pm 6,7$ & $495,2 \pm 5,7$ \\
\hline Relação com LCS & 1,00 & 1,04 & 1,04 & 1,04 & 0,98 & 0,97 & 0,98 \\
\hline E1 & 490 & 506,7 & 509,3 & 508 & 474,35 & 482,15 & 478,3 \\
\hline E2 & 492,2 & 509,1 & 512,5 & 510,8 & 481 & 484,35 & 482,7 \\
\hline E3 & 470 & 517 & 505,7 & 511,4 & 482,25 & 462,25 & 472,3 \\
\hline Média E & $484,1 \pm 12,2$ & $510,9 \pm 5,4$ & $509,2 \pm 3,4$ & $510,1 \pm 1,8$ & $479,2 \pm 4,2$ & $476,3 \pm 12,2$ & $477,8 \pm 5,2$ \\
\hline Relação com LCS & 1,00 & 1,06 & 1,05 & 1,05 & 0,99 & 0,98 & 0,99 \\
\hline Média Geral & $491,4 \pm 9,8$ & & & $512,3 \pm 10,2$ & & & $485,0 \pm 6,6$ \\
\hline Relação com LCS & 1,00 & & & 1,04 & & & 0,99 \\
\hline
\end{tabular}


Conforme pode ser observado na tabela 5.27, a ZAC apresentou dureza média $4 \%$ mais elevada que a dureza média na LCS. Acredita-se que a maior dureza da ZAC em relação à LCS seja devido à deformação das fibras do material pela força de recalque, à microsegregação dos elementos silício, molibdênio, cromo, manganês e níquel nas linhas de fluxo e na LCS, conforme análise EDS apresentada nos itens 5.2.3.7 e 5.2.3.8, e também ao gradiente de temperatura na região da solda. Por outro lado, o MB de uma região próximo à interface com a ZAC, apresentou dureza média $1 \%$ inferior à LCS, o que caracteriza uma variação pouco significativa, podendo ser admitido que a dureza do MB e da LCS em termos médios foram praticamente iguais. Considerando-se esta comparação de médias, pode ser admitido que a dureza na LCS da solda não foi reduzida em relação ao $\mathrm{MB}$ pelo processo de soldagem mas sim se tornou menor em relação à ZAC devido ao aumento da dureza desta região, conforme exposto anteriormente.

\subsubsection{Medições de dureza na Microestrutura da Seção Longitudinal à LCS.}

Analogamente ao efetuado no item 5.2.3.1, foi verificado a dureza das amostras dos parâmetros A1, A2 e A3 no sentido longitudinal à LCS.

Foram testadas três variações para o parâmetro A (corrente elétrica), em relação a seus efeitos na dureza da seção longitudinal à LCS, conforme a seguir:

A1: Corrente elétrica com redução de 14,3\% em relação ao valor recomendado.

A2: Corrente elétrica com valor recomendado, conforme tabela 4.5.

A3: Corrente elétrica com aumento de $14,3 \%$ em relação ao valor recomendado. 
A tabela 5.28 e o gráfico da figura 5.33 mostram os valores de dureza na LCS, na ZAC e no MB para os parâmetros A1, A2 e A3 testados.

Tabela 5.28 Variação da Dureza na LCS em Função da Variação da Corrente Elétrica Sentido Longitudinal à LCS.

\begin{tabular}{|c|c|c|c|c|c|c|c|c|c|c|c|}
\hline \multicolumn{12}{|c|}{ Variação da Dureza (HV) x Variação da Corrente Elétrica - Longitudinal } \\
\hline \multirow{3}{*}{$\begin{array}{c}\text { Parâmetro } \\
\text { A }\end{array}$} & \multicolumn{11}{|c|}{ Distância da linha central da solda (mm) } \\
\hline & \multicolumn{2}{|c|}{ MB } & \multicolumn{3}{|c|}{ ZAC } & LCS & \multicolumn{3}{|c|}{ ZAC } & \multicolumn{2}{|c|}{ MB } \\
\hline & $-1,0$ & $-0,8$ & $-0,6$ & $-0,4$ & $-0,2$ & 0 & 0,2 & 0,4 & 0,6 & 0,8 & 1,0 \\
\hline Média A1 & 460,7 & 473,3 & 496,3 & 490,5 & 497,7 & 436,3 & 468,7 & 492,8 & 497,3 & 457,7 & 459,8 \\
\hline$\sigma \mathrm{A} 1$ & 5,2 & 2,4 & 25,0 & 12,0 & 0,9 & 5,2 & 28,3 & 2,1 & 1,9 & 16,0 & 6,4 \\
\hline Média A2 & 471,8 & 461,2 & 467,2 & 499,0 & 487,8 & 447,7 & 490,2 & 497,5 & 485,7 & 450,8 & 433,8 \\
\hline$\sigma \mathrm{A} 2$ & 2,6 & 5,9 & 24,3 & 21,2 & 13,0 & 12,7 & 13,4 & 11,5 & 7,5 & 10,1 & 4,9 \\
\hline Média A3 & 455,5 & 466,7 & 488,2 & 482,3 & 496,2 & 479,2 & 498,8 & 492,5 & 502,0 & 463,5 & 467,8 \\
\hline$\sigma \mathrm{A} 3$ & 5,9 & 2,4 & 10,6 & 4,2 & 8,7 & 0,2 & 0,2 & 11,5 & 3,3 & 3,5 & 11,5 \\
\hline
\end{tabular}

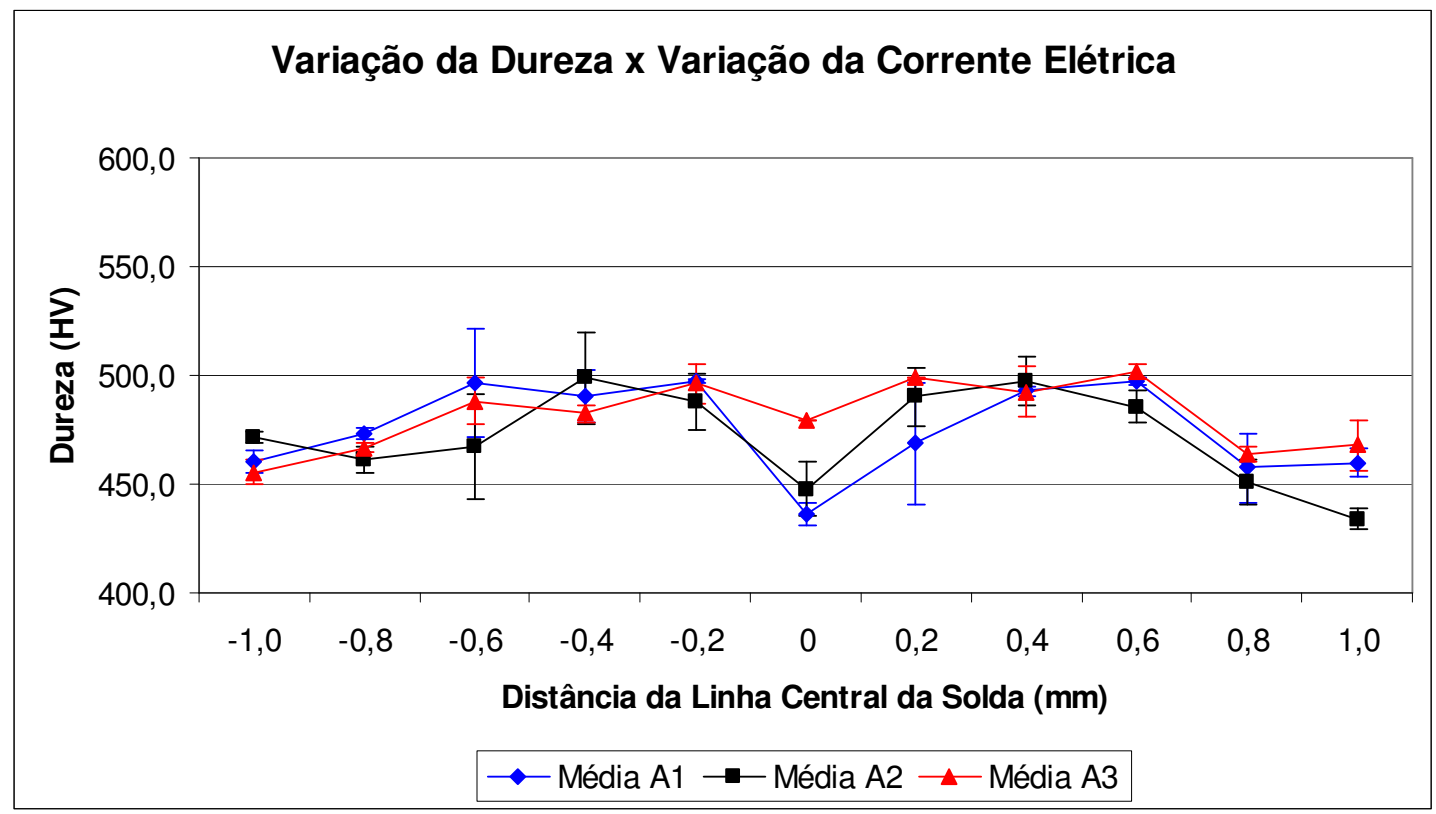

Figura 5.33 Variação da dureza média na LCS em função da variação da corrente elétrica para os parâmetros A1, A2 e A3. Sentido longitudinal à LCS.

Conforme pode ser observado na tabela 5.28 e no gráfico da figura 5.33, o parâmetro A3 apresentou a maior dureza na LCS, e isto está em conformidade com o resultado encontrado no item 5.2.3.1, onde também estão citadas as justificativas para este fato. 
Os valores médios de dureza na LCS, resultantes dos testes com os parâmetros A1, A2 e A3, foram verificados pela Análise de Variância $^{(62)}$ e Testes de Hipóteses ${ }^{(63)}$, considerando-se dados emparelhados, conforme tabelas 5.29 e 5.30 a seguir.

Conforme pode ser visto na tabela 5.29, o valor para $\mathrm{F}$ calculado de 10,04 é maior que o valor para $\mathrm{F}$ tabelado $\left(\mathrm{F}_{15} ; 5 \%\right)$ de 3,68 , e, portanto, a hipótese $\mathrm{H}_{\mathrm{O}}$ é rejeitada. Isto permite concluir ao nível de 5\% de significância, que as três médias de durezas dos parâmetros A1, A2 e A3 são diferentes, e, portanto, a dureza na LCS variou em função da variação da corrente elétrica.

Tabela 5.29 Análise de variância para dureza na LCS dos parâmetros A1, A2 e A3. Sentido Longitudinal à LCS.

\begin{tabular}{|c|c|c|c|c|c|c|c|c|c|}
\hline \multicolumn{10}{|c|}{ Análise de Variância para Parâmetro A } \\
\hline \multirow[t]{3}{*}{ Amostra } & \multicolumn{9}{|c|}{ Dureza na LCS (HV) } \\
\hline & \multicolumn{3}{|c|}{ A1 } & \multicolumn{3}{|c|}{ A2 } & \multicolumn{3}{|c|}{ A3 } \\
\hline & $\mathrm{x}_{\mathrm{ij}}$ & $\mathrm{X}_{\mathrm{ij}-490}$ & $\mathrm{x}_{\mathrm{i}-490^{2}}$ & $\mathrm{x}_{\mathrm{ij}}$ & $\mathrm{X}_{\mathrm{ij}-490}$ & $\mathrm{x}_{\mathrm{ij}-490^{2}}$ & $\mathrm{x}_{\mathrm{ij}}$ & $\mathrm{x}_{\mathrm{i}-490}$ & $\mathrm{x}_{\mathrm{i}-490^{2}}$ \\
\hline 1 & 450 & -40 & 1600 & 471 & -19 & 361 & 490 & 0 & 0 \\
\hline 2 & 420 & -70 & 4900 & 410 & -80 & 6400 & 475 & -15 & 225 \\
\hline 3 & 445 & -45 & 2025 & 435 & -55 & 3025 & 473 & -17 & 289 \\
\hline 4 & 438 & -52 & 2704 & 475 & -15 & 225 & 475 & -15 & 225 \\
\hline 5 & 450 & -40 & 1600 & 450 & -40 & 1600 & 472 & -18 & 324 \\
\hline 6 & 415 & -75 & 5625 & 445 & -45 & 2025 & 490 & 0 & 0 \\
\hline Média & 436,3 & - & - & 447,7 & - & - & 479,2 & - & - \\
\hline$\sigma$ & 15,3 & - & - & 24,0 & - & - & 8,5 & - & - \\
\hline \multicolumn{2}{|c|}{ Fonte de Variação } & \multicolumn{2}{|c|}{$\begin{array}{l}\text { Soma de } \\
\text { Quadrados }\end{array}$} & \multicolumn{2}{|c|}{$\begin{array}{l}\text { Graus de } \\
\text { Liberdade }\end{array}$} & \multicolumn{2}{|c|}{$\begin{array}{c}\text { Quadrado } \\
\text { Médio }\end{array}$} & $\mathrm{F}$ & $\mathrm{F}_{\alpha}$ \\
\hline \multicolumn{2}{|c|}{ Entre Amostras } & \multicolumn{2}{|c|}{$5.910,78$} & \multicolumn{2}{|c|}{2} & \multicolumn{2}{|c|}{$2.955,39$} & 10,04 & $\mathrm{~F}_{15 ; 5 \%}=3,68$ \\
\hline \multicolumn{2}{|c|}{ Residual } & \multicolumn{2}{|c|}{$4.415,50$} & \multicolumn{2}{|c|}{15} & \multicolumn{2}{|c|}{294,37} & & \\
\hline \multicolumn{2}{|c|}{ Total } & \multicolumn{2}{|c|}{$10.326,28$} & \multicolumn{2}{|c|}{17} & \multicolumn{2}{|c|}{ - } & & \\
\hline
\end{tabular}

Do mesmo modo, conforme mostrado na tabela 5.30, o valor para t calculado $\left(\mathrm{t}_{5}\right)$ de $-1,34$ para a comparação das médias A1xA2 é menor em módulo que o valor para t tabelado $\left(\mathrm{t}_{5 ; 5 \%}\right)$ de 2,57. 
Por outro lado, os valores para t calculado $\left(\mathrm{t}_{5}\right)$ de $-5,41$ para a comparação das médias A1xA3 e de -3,39 para a comparação das médias A2xA3 são maiores em módulo que o valor para $\mathrm{t}$ tabelado $\left(\mathrm{t}_{5 ; 5 \%}\right)$ de 2,57 . Isto permite concluir, ao nível de $5 \%$ de significância, que os valores médios de dureza na LCS para os parâmetros A1 e A2 são iguais, ao passo que o valor médio de dureza na LCS para o parâmetro A3 é diferente de A1 e de A2.

Tabela 5.30 Testes de hipóteses para dureza na LCS dos parâmetros A1, A2 e A3.

\begin{tabular}{|c|c|c|c|c|c|c|c|c|c|}
\hline \multicolumn{10}{|c|}{ Teste de Hipótese para Parâmetro A } \\
\hline \multirow[t]{2}{*}{ Amostra } & \multicolumn{3}{|c|}{$\begin{array}{c}\text { Dureza na LCS } \\
(\mathrm{HV})\end{array}$} & \multicolumn{2}{|c|}{$\mathrm{A} 1 \times \mathrm{A} 2$} & \multicolumn{2}{|c|}{$\mathrm{A} 1 \times \mathrm{A} 3$} & \multicolumn{2}{|c|}{$\mathrm{A} 2 \times \mathrm{A} 3$} \\
\hline & A1 & $\mathrm{A} 2$ & $\mathrm{~A} 3$ & $\mathrm{~d}_{\mathrm{A} 1 \mathrm{~A} 2}$ & $\mathrm{~d}_{\mathrm{A} 1 \mathrm{~A} 2}{ }^{2}$ & $\mathrm{~d}_{\mathrm{A} 1 \mathrm{~A} 3}$ & $\mathrm{~d}_{\mathrm{A} 1 \mathrm{~A} 3}{ }^{2}$ & $\mathrm{~d}_{\mathrm{A} 2 \mathrm{~A} 3}$ & $\mathrm{~d}_{\mathrm{A} 2 \mathrm{~A} 3^{2}}$ \\
\hline 1 & 450 & 471 & 490 & -21 & 441 & -40 & 1.600 & -19 & 361 \\
\hline 2 & 420 & 410 & 475 & 10 & 100 & -55 & 3.025 & -65 & 4.225 \\
\hline 3 & 445 & 435 & 473 & 10 & 100 & -28 & 784 & -38 & 1.444 \\
\hline 4 & 438 & 475 & 475 & -37 & 1.369 & -37 & 1.369 & 0 & 0 \\
\hline 5 & 450 & 450 & 472 & 0 & 0 & -22 & 484 & -22 & 484 \\
\hline 6 & 415 & 445 & 490 & -30 & 900 & -75 & 5.625 & -45 & 2.025 \\
\hline & & & $\Sigma$ & -68 & 2.910 & -257 & 12.887 & $\begin{array}{l}-189 \\
\end{array}$ & 8.539 \\
\hline & & & $\mathrm{sd}^{2}$ & \multicolumn{2}{|c|}{427,87} & \multicolumn{2}{|c|}{375,77} & \multicolumn{2}{|c|}{517,10} \\
\hline & & & $\mathrm{sd}$ & \multicolumn{2}{|c|}{20,68} & \multicolumn{2}{|c|}{19,38} & \multicolumn{2}{|c|}{22,74} \\
\hline & & & $\mathrm{t}_{5}$ & \multicolumn{2}{|c|}{$-1,34$} & & 41 & \multicolumn{2}{|c|}{$-3,39$} \\
\hline & & & $\mathrm{t}_{5 ; 5 \%}$ & \multicolumn{6}{|c|}{2,57} \\
\hline
\end{tabular}

Desta forma, pode-se afirmar que o valor médio da dureza na LCS aumentou em 7,0\% quando a intensidade da corrente elétrica aumentou em 14,3\% em relação ao valor recomendado, e que não houve variação significativa de dureza, quando a corrente foi reduzida em 14,3\% em relação ao valor recomendado, conforme análises estatísticas anteriores e tabela 5.31 a seguir. 
Tabela 5.31 Variação da dureza na LCS em função da variação da corrente elétrica. Sentido longitudinal à LCS.

\begin{tabular}{|c|c|c|c|c|c|}
\hline \multirow{2}{*}{ Parâmetro } & \multirow{2}{*}{\begin{tabular}{c} 
Tensão de Soldagem \\
\cline { 3 - 6 }
\end{tabular}} & \multirow{2}{*}{$\mathrm{V}$} & \multicolumn{2}{|c|}{ Corrente de Soldagem } & \multicolumn{2}{c|}{ Dureza na LCS } \\
\cline { 3 - 6 } & & Intensidade & Variação & Valor Médio & Variação \\
\cline { 3 - 6 } & 3,6 & $4.706,6$ & $-14,3$ & 436,3 & $-2,5$ \\
\hline A1 & 4,2 & $5.491,9$ & 0,0 & 447,7 & 0,0 \\
\hline A2 & 4,8 & $6.277,2$ & 14,3 & 479,2 & $+7,0$ \\
\hline A3 & & \multicolumn{2}{c}{} \\
\hline
\end{tabular}

\subsubsection{Comparação de Dureza da Seção Transversal e Longitudinal à LCS.}

A tabela 5.32 mostra a comparação das durezas no sentido transversal e longitudinal à LCS para as amostras do parâmetro A.

Tabela 5.32 Comparação de dureza na seção transversal e longitudinal à LCS para as amostras do parâmetro A.

\begin{tabular}{|c|c|c|c|c|c|c|c|c|}
\hline Seção & $\begin{array}{l}\text { A1 } \\
\text { HV } \\
\end{array}$ & $\begin{array}{c}\text { Relação } \\
(\mathrm{T} / \mathrm{L}) \\
\%\end{array}$ & $\begin{array}{l}\text { A2 } \\
\text { HV } \\
\end{array}$ & $\begin{array}{c}\text { Relação } \\
\text { (T/L) } \\
\%\end{array}$ & $\begin{array}{l}\text { A3 } \\
\text { HV }\end{array}$ & $\begin{array}{c}\text { Relação } \\
(\mathrm{T} / \mathrm{L}) \\
\%\end{array}$ & $\begin{array}{c}\text { Média A } \\
\text { HV }\end{array}$ & $\begin{array}{c}\text { Relação } \\
(\mathrm{T} / \mathrm{L}) \\
\%\end{array}$ \\
\hline Longitudinal (L) & $436,3 \pm 5,2$ & - & $447,7 \pm 12,7$ & - & $479,2 \pm 0,2$ & - & $454,4 \pm 22,2$ & - \\
\hline Transversal (T) & $472,2 \pm 20,0$ & 8,2 & $485,3 \pm 18,9$ & 8,4 & $525,7 \pm 9,4$ & 9,7 & $494,4 \pm 27,9$ & 8,8 \\
\hline
\end{tabular}

Conforme pode ser observado na tabela 5.32, a dureza no sentido transversal à LCS é em média $8,8 \%$ maior que a respectiva dureza no sentido longitudinal Acredita-se que esta diferença de dureza possa advir da deformação das linhas de fluxo do material através da força de recalque e da temperatura de soldagem, que faz com que a dureza na seção transversal à LCS seja maior que a dureza na seção longitudinal. 


\subsubsection{Medições de Dureza na Ponta dos Dentes.}

A dureza na ponta dos dentes foi verificada conforme figura 4.3(a). Os resultados estão indicados na tabela 5.33 e no gráfico da figura 5.34.

Tabela 5.33 Dureza média na ponta dos dentes em função de diferentes parâmetros de soldagem.

\begin{tabular}{|c|c|c|c|c|}
\hline \multirow{5}{*}{ Parâmetro } & \multicolumn{4}{|c|}{ Distância entre Medições (mm) } \\
\cline { 2 - 5 } & $-0,2$ & 0 & 0,2 & Média \\
\hline \multirow{2}{*}{ A1 } & 972,1 & 956,2 & 990,8 & 973,0 \\
\hline$\sigma \mathrm{A} 1$ & 20,2 & 25,1 & 14,0 & 6,3 \\
\hline A2 & 980,1 & 955,2 & 969,1 & 968,1 \\
\hline$\sigma \mathrm{A} 2$ & 18,2 & 9,5 & 10,0 & 5,9 \\
\hline $\mathrm{A} 3$ & 992,3 & 990,6 & 1006,8 & 996,6 \\
\hline$\sigma \mathrm{A} 3$ & 11,7 & 3,3 & 9,4 & 1,9 \\
\hline $\mathrm{C} 1$ & 995,7 & 990,6 & 992,2 & 992,8 \\
\hline$\sigma \mathrm{C} 1$ & 23,9 & 17,1 & 7,9 & 16,3 \\
\hline $\mathrm{D} 3$ & 985,2 & 991,8 & 980,0 & 985,7 \\
\hline$\sigma \mathrm{D} 3$ & 1,6 & 8,7 & 28,6 & 13,0 \\
\hline F1 & 1004,0 & 1002,0 & 1000,5 & 1002,2 \\
\hline$\sigma \mathrm{F} 1$ & 1,8 & 19,6 & 3,7 & 8,4 \\
\hline
\end{tabular}

Conforme pode ser observado na tabela 5.33 e no gráfico da figura 5.34, a dureza na ponta dos dentes próximo da área soldada não foi alterada de forma significativa pelo calor produzido durante a soldagem em comparação à dureza da ponta dos dentes de uma região que não foi soldada (parâmetro F1). Houve uma redução na dureza, porém a dureza da ponta dos dentes permaneceu dentro do especificado para a serra de fita bimetálica. Isto pode ser explicado pelo fato do calor gerado na soldagem e transmitido para os dentes não ter ultrapassado muito além da temperatura de revenimento dos dentes da serra de fita, que é de $650^{\circ} \mathrm{C}$. 


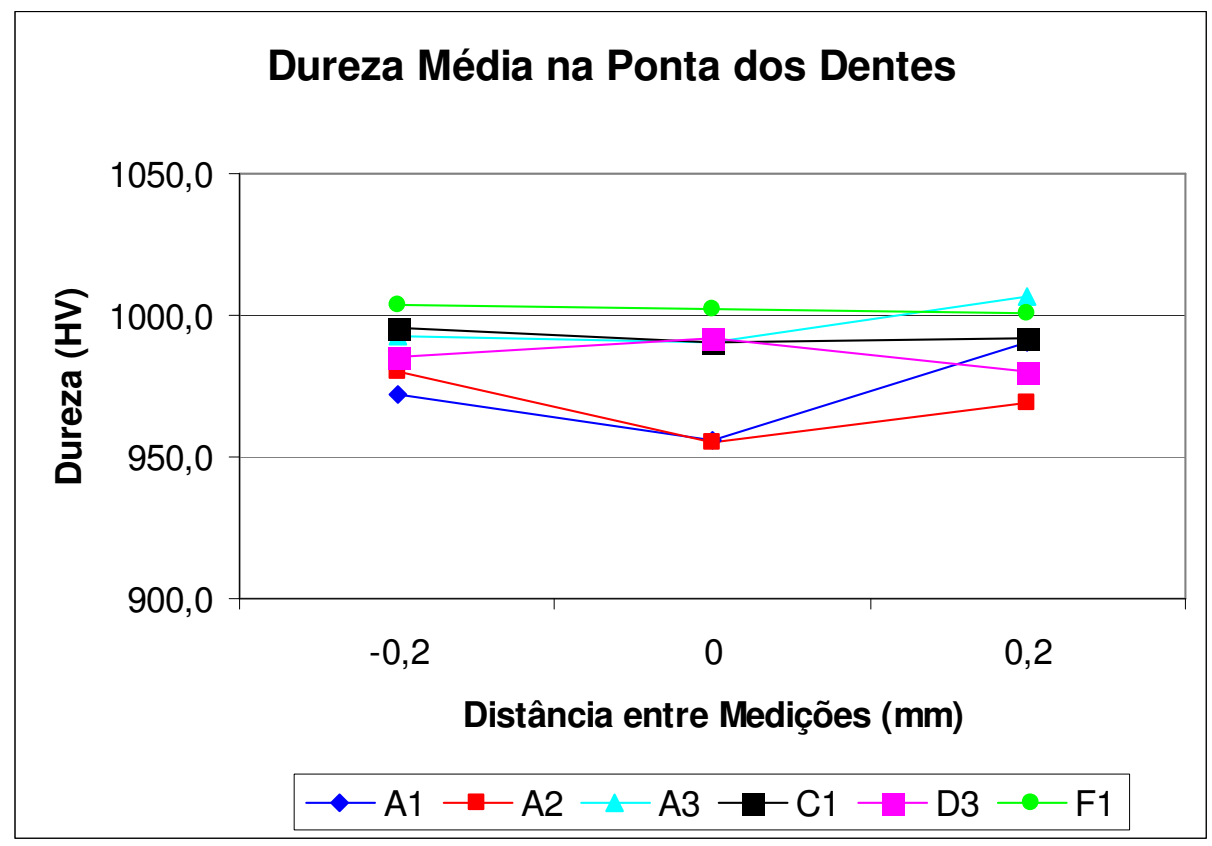

Figura 5.34 Dureza média na ponta dos dentes em função de vários parâmetros de soldagem.

\subsection{RESULTADOS DOS ENSAIOS DE TORÇÃO.}

Os ensaios de torção foram executados conforme descrito no item 4.5.2 do capítulo anterior, com o objetivo de simular um funcionamento real da lâmina de serra de fita bimetálica, onde a mesma está sujeita a torções cíclicas de $90^{\circ}$, quando passam pelos volantes dos equipamentos de serrar.

\subsubsection{Influência dos Parâmetros de Testes nos Ensaios de Torção.}

A maioria dos corpos de prova apresentou resultado satisfatório nos ensaios de torção. Do total de 39 corpos de prova, apenas $11(28,2 \%)$ tiveram ruptura na LCS. Para o restante dos corpos de prova a fratura ocorreu no metal de base. Dos corpos de prova que romperam na LCS, apenas 2 foram reprovados (C12TO e D12TO), conforme procedimento descrito em 4.5.2.2, o que resulta em 5,1\% do total. Os resultados dos ensaios de torção estão relacionados na tabela 5.34. 
Tabela 5.34 Resultados dos Ensaios de Torção.

\begin{tabular}{|c|c|c|c|c|c|c|c|c|c|c|c|}
\hline \multicolumn{12}{|c|}{ Resultados dos Ensaios de Torção } \\
\hline \multirow{2}{*}{$\begin{array}{l}\text { Identif. } \\
\text { do } \\
\text { c.d.p. }\end{array}$} & \multirow{2}{*}{$\begin{array}{l}\begin{array}{c}\text { Ângulo } \\
\text { de }\end{array} \\
\text { Ruptura } \\
\text { o }\end{array}$} & \multicolumn{3}{|c|}{$\begin{array}{l}\text { Local da } \\
\text { Ruptura }\end{array}$} & \multirow{2}{*}{$\begin{array}{c}\text { Característica } \\
\text { da Fratura }\end{array}$} & \multirow{2}{*}{$\begin{array}{l}\text { Identif. } \\
\text { do } \\
\text { c.d.p. }\end{array}$} & \multirow{2}{*}{$\begin{array}{l}\begin{array}{c}\text { Ângulo } \\
\text { de }\end{array} \\
\text { Ruptura } \\
\text { o }\end{array}$} & \multicolumn{3}{|c|}{$\begin{array}{l}\text { Local da } \\
\text { Ruptura }\end{array}$} & \multirow{2}{*}{$\begin{array}{c}\text { Característica } \\
\text { da Fratura }\end{array}$} \\
\hline & & LCS & $\mathrm{ZAC}$ & MB & & & & LCS & $\mathrm{ZAC}$ & MB & \\
\hline A11TO & 585,0 & - & - & $\mathrm{X}$ & Reta e plana. & D11TO & 495,0 & $\mathrm{X}$ & - & - & Reta e plana. \\
\hline $\mathrm{A} 12 \mathrm{TO}$ & 585,0 & - & - & $\mathrm{X}$ & Reta e plana. & D12TO & 337,5 & $\mathrm{X}$ & - & - & Reta e plana. \\
\hline A13TO & 540,0 & - & - & $\mathrm{X}$ & Reta e plana. & D13TO & 450,0 & $\mathrm{X}$ & - & - & Reta e plana. \\
\hline$\mu \mathrm{A} 1$ & 570,0 & - & - & - & - & $\mu \mathrm{D} 1$ & 427,5 & - & - & - & - \\
\hline$\sigma \mathrm{A} 1$ & 26,0 & - & - & - & - & $\sigma \mathrm{D} 1$ & 81,1 & - & - & - & - \\
\hline $\mathrm{A} 21 \mathrm{TO}$ & 315,0 & - & - & $X$ & Reta e plana. & D21TO & 517,5 & - & - & $X$ & Reta e plana. \\
\hline A22TO & 360,0 & $\mathrm{X}$ & - & - & Reta e plana. & D22TO & 382,5 & - & - & $\mathrm{X}$ & Reta e plana. \\
\hline A23TO & 540,0 & - & - & $\mathrm{X}$ & Reta e plana. & D23TO & 517,5 & - & - & $X$ & Reta e plana. \\
\hline$\mu \mathrm{A} 2$ & 405,0 & - & - & - & - & $\mu \mathrm{D} 2$ & 472,5 & - & - & - & - \\
\hline$\sigma \mathrm{A} 2$ & 119,1 & - & - & - & - & $\sigma \mathrm{D} 2$ & 77,9 & - & - & - & - \\
\hline A31TO & 585,0 & - & - & $X$ & Reta e plana. & D31TO & 450,0 & $\mathrm{X}$ & - & - & Reta e plana. \\
\hline A32TO & 540,0 & - & - & $X$ & Reta e plana. & D32TO & 540,0 & - & - & $X$ & Reta e plana. \\
\hline A33TO & 427,5 & $\mathrm{X}$ & - & - & Reta e plana. & D33TO & 450,0 & - & - & $\mathrm{X}$ & Reta e plana. \\
\hline$\mu \mathrm{A} 3$ & 517,5 & - & - & - & - & $\mu \mathrm{D} 3$ & 480,0 & - & - & - & - \\
\hline$\sigma \mathrm{A} 3$ & 81,1 & - & - & - & - & $\sigma \mathrm{D} 3$ & 52,0 & - & - & - & - \\
\hline B11TO & 517,5 & - & - & $\mathrm{X}$ & Reta e plana. & E11TO & 540,0 & - & - & $\mathrm{X}$ & Reta e plana. \\
\hline B12TO & 405,0 & $\mathrm{X}$ & - & - & Reta e plana. & E12TO & 540,0 & - & - & $X$ & Reta e plana. \\
\hline B13TO & 540,0 & - & - & $\mathrm{X}$ & Reta e plana. & E13TO & 495,0 & - & - & $\mathrm{X}$ & Reta e plana. \\
\hline$\mu \mathrm{B} 1$ & 487,5 & - & - & - & - & $\mu \mathrm{E} 1$ & 525,0 & - & - & - & - \\
\hline$\sigma \mathrm{B} 1$ & 72,3 & - & - & - & - & $\sigma \mathrm{E} 1$ & 26,0 & - & - & - & - \\
\hline B31TO & 540,0 & - & - & $\mathrm{X}$ & Reta e plana. & E21TO & 540,0 & $\mathrm{X}$ & - & - & Reta e plana. \\
\hline $\mathrm{B} 32 \mathrm{TO}$ & 585,0 & - & - & $\mathrm{X}$ & Reta e plana. & E22TO & 540,0 & - & - & $\mathrm{X}$ & Reta e plana. \\
\hline B33TO & 405,0 & $\mathrm{X}$ & - & - & Reta e plana. & E23TO & 540,0 & - & - & $X$ & Reta e plana. \\
\hline$\mu \mathrm{B} 3$ & 510,0 & - & - & - & - & $\mu \mathrm{E} 2$ & 540,0 & - & - & - & - \\
\hline$\sigma \mathrm{B} 3$ & 93,7 & - & - & - & - & $\sigma \mathrm{E} 2$ & 0,0 & - & - & - & - \\
\hline C11TO & 585,0 & - & - & $\mathrm{X}$ & Reta e plana. & E31TO & 450,0 & $\mathrm{X}$ & $\mathrm{X}$ & $\mathrm{X}$ & $\begin{array}{c}\text { Irregular com } \\
\text { desvios. }\end{array}$ \\
\hline $\mathrm{C} 12 \mathrm{TO}$ & 270,0 & $\mathrm{X}$ & - & - & Reta e plana. & E32TO & 517,5 & - & - & $\mathrm{X}$ & Reta e plana. \\
\hline C13TO & 495,0 & - & - & $\mathrm{X}$ & Reta e plana. & E33TO & 472,5 & - & - & $\mathrm{X}$ & Reta e plana. \\
\hline$\mu \mathrm{C} 1$ & 450,0 & - & - & - & - & $\mu \mathrm{E} 3$ & 480,0 & - & - & - & - \\
\hline$\sigma \mathrm{C} 1$ & 162,2 & - & - & - & - & $\sigma \mathrm{E} 3$ & 34,4 & - & - & - & - \\
\hline $\mathrm{C} 31 \mathrm{TO}$ & 540,0 & - & - & $\mathrm{X}$ & Reta e plana. & MB 1 & 585,0 & - & - & $\mathrm{X}$ & Reta e plana. \\
\hline $\mathrm{C} 32 \mathrm{TO}$ & 540,0 & - & - & $\mathrm{X}$ & Reta e plana. & MB 2 & 585,0 & - & - & $X$ & Reta e plana. \\
\hline C33TO & 562,5 & - & - & $\mathrm{X}$ & Reta e plana. & MB 3 & 585,0 & - & - & $\mathrm{X}$ & Reta e plana. \\
\hline$\mu \mathrm{C} 3$ & 547,5 & - & - & - & - & $\mu \mathrm{MB}$ & 585,0 & - & - & - & - \\
\hline$\sigma \mathrm{C} 3$ & 13,0 & - & - & - & - & $\sigma \mathrm{MB}$ & 0,0 & - & - & - & - \\
\hline
\end{tabular}


Os corpos de prova dos parâmetros A1, C3 e E1 apresentaram excelente desempenho no ensaio de torção, tendo sido todos aprovados, conforme procedimento descrito no item 4.5.2.2 e conforme comparação com o resultado do ensaio de torção do metal de base sem a solda. Ficou evidente através destes resultados, que uma corrente elétrica de menor intensidade, conforme parâmetro A1, e, analogamente, uma menor influência do tratamento térmico de revenimento, conforme parâmetros C3 e E1, resultaram em uma junta soldada com melhor ductilidade e maior capacidade de suportar os esforços de torção. Uma menor influência do tratamento térmico de revenimento diz respeito a uma redução na quantidade de ciclos de revenimento, associado a uma melhor relação dos parâmetros tempo e temperatura em função do metal de base D-6a.

Por outro lado, todos os corpos de prova do parâmetro D1 resultaram em falhas na LCS, quando submetidos aos esforços de torção. O corpo de prova D12TO rompeu com 337,50, não satisfazendo o requisito mínimo de $360^{\circ}$, conforme item 4.5.2.2. Ficou evidenciado que o tratamento térmico de revenimento executado à temperaturas abaixo de $550^{\circ}\left(500^{\circ} \mathrm{C}\right.$ no caso de D1) não foi suficiente para reduzir as tensões internas do processo de soldagem e proporcionar uma boa resistência à torção para a junta soldada. Isto também pode ser associado ao fato de que o parâmetro D1 apresentou austenita retida de dureza elevada, conforme tabelas 5.1, 5.3 e 5.26, o que tornou a junta soldada mais frágil.

Variações na pressão de recalque não influenciaram significativamente nos resultados dos ensaios de torção. Todos os corpos de prova dos parâmetros B1 e B3 foram aprovados, conforme procedimento citado anteriormente em 4.5.2.2. 
O parâmetro A2 apresentou resultados pouco satisfatórios nos ensaios de torção, pois sua microestrutura revelou presença de austenita retida, conforme análises metalográficas dos itens 5.1.1 e 5.1.3, e isto pode ter contribuído para a pouca eficiência deste parâmetro.

O revenimento influenciou no resultado do ensaio de torção. Menor quantidade de revenidos associado a uma temperatura acima de $550^{\circ} \mathrm{C}$ mostrou resultados mais satisfatórios, conforme aqueles que foram apresentados pelos parâmetros C3, D3, E1, E2 e E3. A ausência do revenimento, conforme parâmetro de teste $\mathrm{C} 1$, não comprometeu o resultado médio do ensaio, porém um dos corpos de prova (C12T0) apresentou um resultado muito deficiente, tendo suportado somente $270^{\circ}$ no ensaio de torção. Por este motivo este parâmetro foi reprovado, por não atender aos requisitos mínimos conforme item 4.5.2.2.

Praticamente todos os corpos de prova apresentaram fraturas do tipo reta e plana nas inspeções visuais. As características das fraturas serão melhor elucidadas no item 5.3.2.

\subsubsection{Análises das Fraturas dos Ensaios de Torção.}

Com o objetivo de caracterizar a natureza das fraturas, alguns corpos de prova dos ensaios de torção foram submetidos à análises no MEV. Todas as amostras analisadas apresentaram uma região dúctil e outra frágil na superfície fraturada, conforme mostrado na figura 5.35, cujas proporções variaram em função dos parâmetros de soldagem utilizados. A região dúctil, de cor clara e levemente mais grosseira, foi caracterizada como fratura por mecanismo de crescimento de auvéolos ${ }^{(66,68,69)}$. A região frágil, de cor escura e levemente mais lisa, foi caracterizada como fratura por mecanismo de clivagem ${ }^{(67-69)}$. 


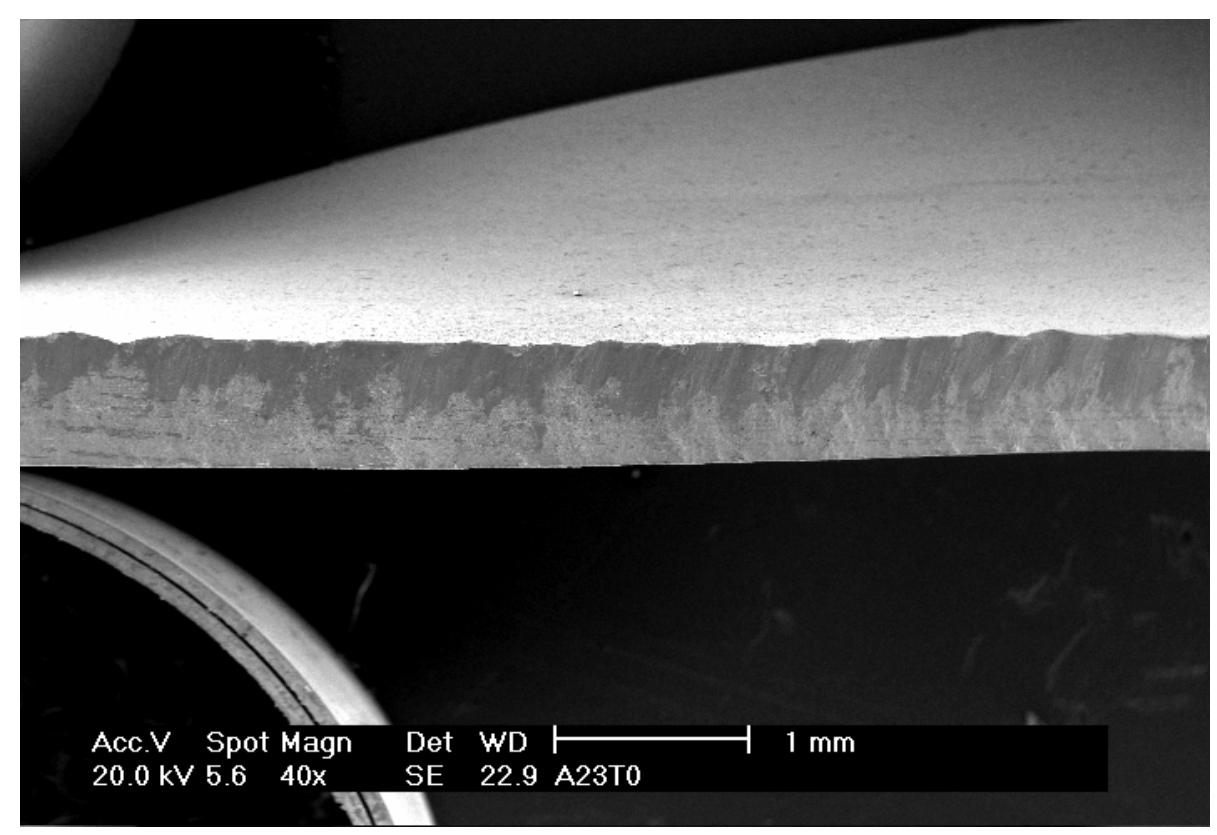

Figura 5.35 Superfície fraturada em ensaio de torção da amostra A23TO, mostrando região clara com característica dúctil (mecanismo alveolar) e região escura com característica frágil (mecanismo por clivagem). MEV. 40X.

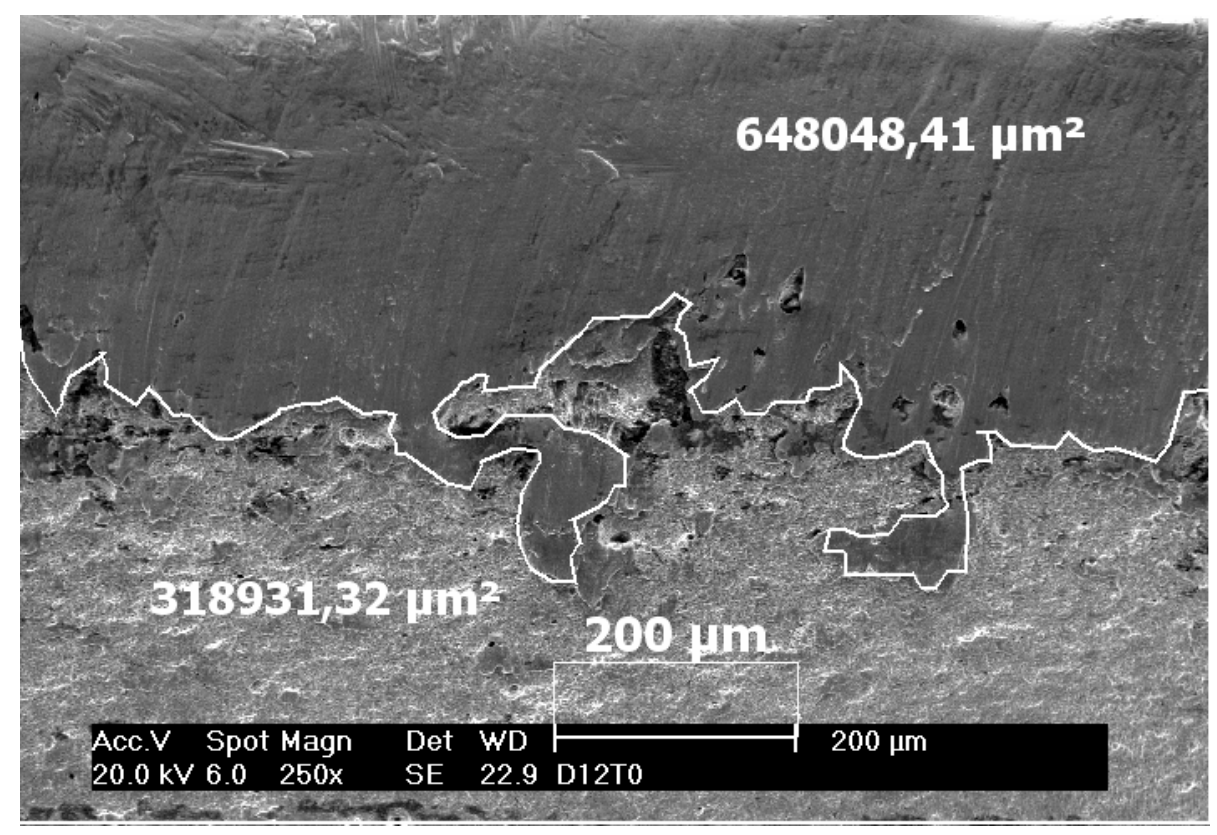

Figura 5.36 Superfície fraturada em ensaio de torção da amostra D12TO, mostrando região clara com característica dúctil (mecanismo alveolar) e região escura com característica frágil (mecanismo por clivagem). MEV. 250X. 


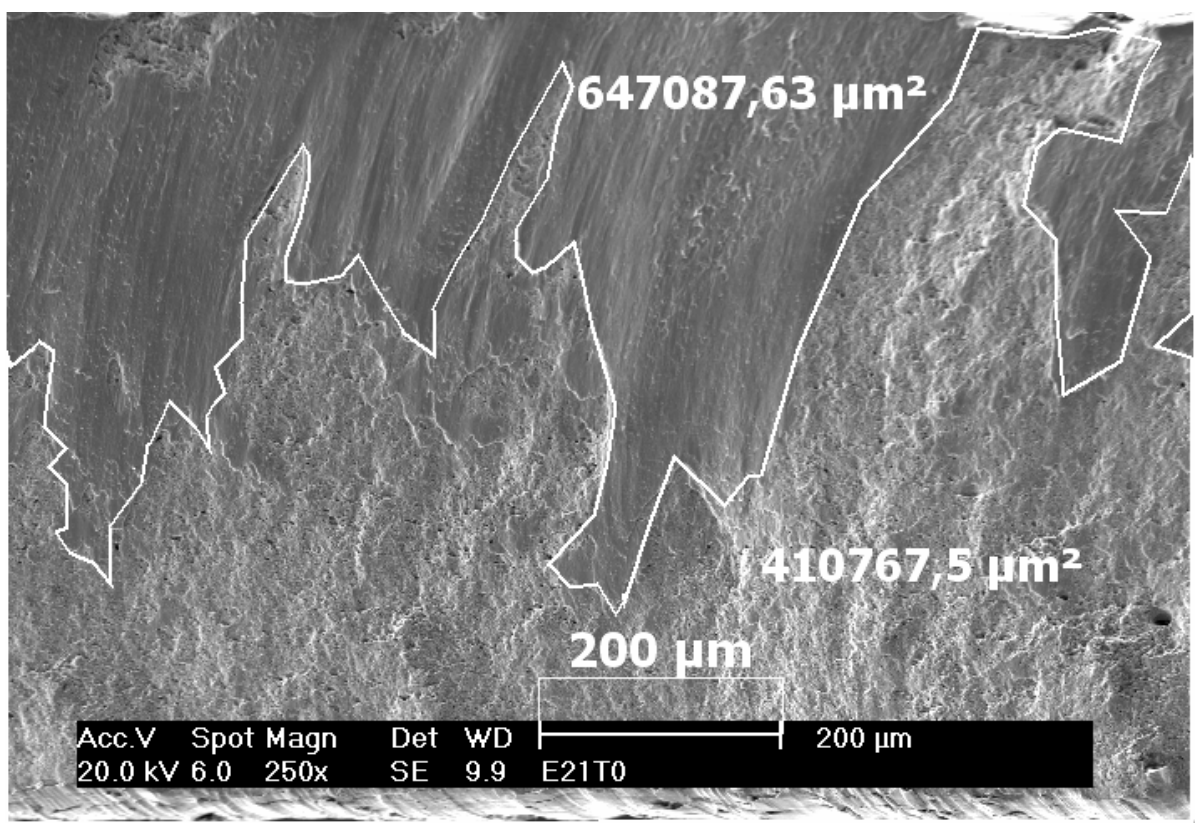

Figura 5.37 Superfície fraturada em ensaio de torção da amostra E21TO, mostrando região clara com característica dúctil (mecanismo alveolar) e região escura com característica frágil (mecanismo por clivagem). MEV. 250X.

Foi determinada a proporção de região dúctil em relação à região total da fratura das amostras analisada no MEV, através da medição das respectivas áreas em lupa estereoscópica, conforme indicado em 4.6, e os resultados estão mostrados na tabela 5.35.

Tabela 5.35 Determinação da relação da área da região dúctil $\mathrm{x}$ área total da fratura.

\begin{tabular}{|c|c|c|c|c|c|c|c|}
\hline \multicolumn{7}{|c|}{ Determinação da relação da área da região dúctil x área total da fratura. } \\
\hline $\begin{array}{c}\text { Identif. } \\
\text { do c.d.p. }\end{array}$ & Parâmetro & Área da Região Dúctil & Área Total & $\begin{array}{c}\text { Relação } \\
\text { Dúctil/Total } \\
\%\end{array}$ & $\begin{array}{c}\text { Ângulo da } \\
\text { Fratura } \\
\text { o }\end{array}$ & $\begin{array}{c}\text { Dureza Média } \\
\text { na LCS } \\
\text { HV }\end{array}$ & $\begin{array}{c}\text { Local da } \\
\text { Fratura }\end{array}$ \\
\hline A22TO & A2 & $420.060,99$ & $652.747,23$ & 64,4 & 360,0 & $485,3 \pm 18,9$ & LCS \\
\hline B12TO & B1 & $400.342,47$ & $648.048,41$ & 61,8 & 405,0 & $459,2 \pm 31,3$ & LCS \\
\hline B33TO & B3 & $360.582,66$ & $650.514,17$ & 55,4 & 405,0 & $502,7 \pm 4,2$ & LCS \\
\hline C33TO & C3 & $382.075,44$ & $650.731,84$ & 58,7 & 562,5 & $494,0 \pm 18,4$ & MB \\
\hline D12TO & D1 & $318.931,32$ & $648.048,41$ & 49,2 & 337,5 & $508,3 \pm 14,6$ & LCS \\
\hline D13TO & D1 & $319.916,49$ & $652.925,50$ & 49,0 & 450,0 & $508,3 \pm 14,7$ & LCS \\
\hline D31TO & D3 & $337.865,45$ & $649.579,66$ & 52,0 & 450,0 & $494,8 \pm 4,0$ & LCS \\
\hline E21TO & E2 & $410.767,50$ & $647.087,63$ & 63,5 & 540,0 & $492,2 \pm 9,7$ & LCS \\
\hline *C12TO & C1 & - & - & - & 270,0 & $730,8 \pm 56,3$ & LCS \\
\hline
\end{tabular}

* Este corpo de prova apresentou fratura com desvios, não sendo possível determinar a região clara. 
Conforme pode ser observado na tabela 5.35 e figuras 5.36 e 5.37, a proporção de região clara é reduzida com o aumento da dureza na LCS, indicando que os corpos de prova que apresentaram maior dureza tiveram uma redução em sua ductilidade, como era esperado.

O corpo de prova A22TO apresentou fratura na LCS com $360^{\circ}$, resultado mínimo aceitável para este ensaio, conforme procedimento de teste do item 4.5.2.2. Por outro lado, a relação das áreas da região clara e total para a amostra deste corpo de prova indica quantidade maior de área dúctil $(64,4 \%)$ em relação à frágil. Isto pode ser explicado pela provável existência de austenita retida muito próximo à LCS, considerando-se que o parâmetro A2 apresentou austenita retida nas análises metalográficas, conforme relacionado anteriormente nas tabelas 5.1 e 5.3.

Ficou evidente a influência da temperatura e tempo de revenido na resistência à torção. Os corpos de prova que foram revenidos a $650^{\circ}(\mathrm{C} 3, \mathrm{E} 1$ e E2) apresentaram melhores resultados nos ensaios de torção, acompanhados por melhor relação de área dúctil/total, do que os corpos de prova que foram revenidos à temperatura de $500^{\circ}$ (D1).

O corpo de prova C12TO rompeu na LCS com apenas $270^{\circ}$. A alta dureza na LCS de $(730,8 \pm 56,3) \mathrm{HV}$ e a fratura com desvios identificada pelo MEV, conforme mostrado na fotomicrografia da figura 5.38, justificam a característica de fratura frágil por clivagem da junta soldada com o parâmetro C1, onde não houve revenimento após a soldagem. 


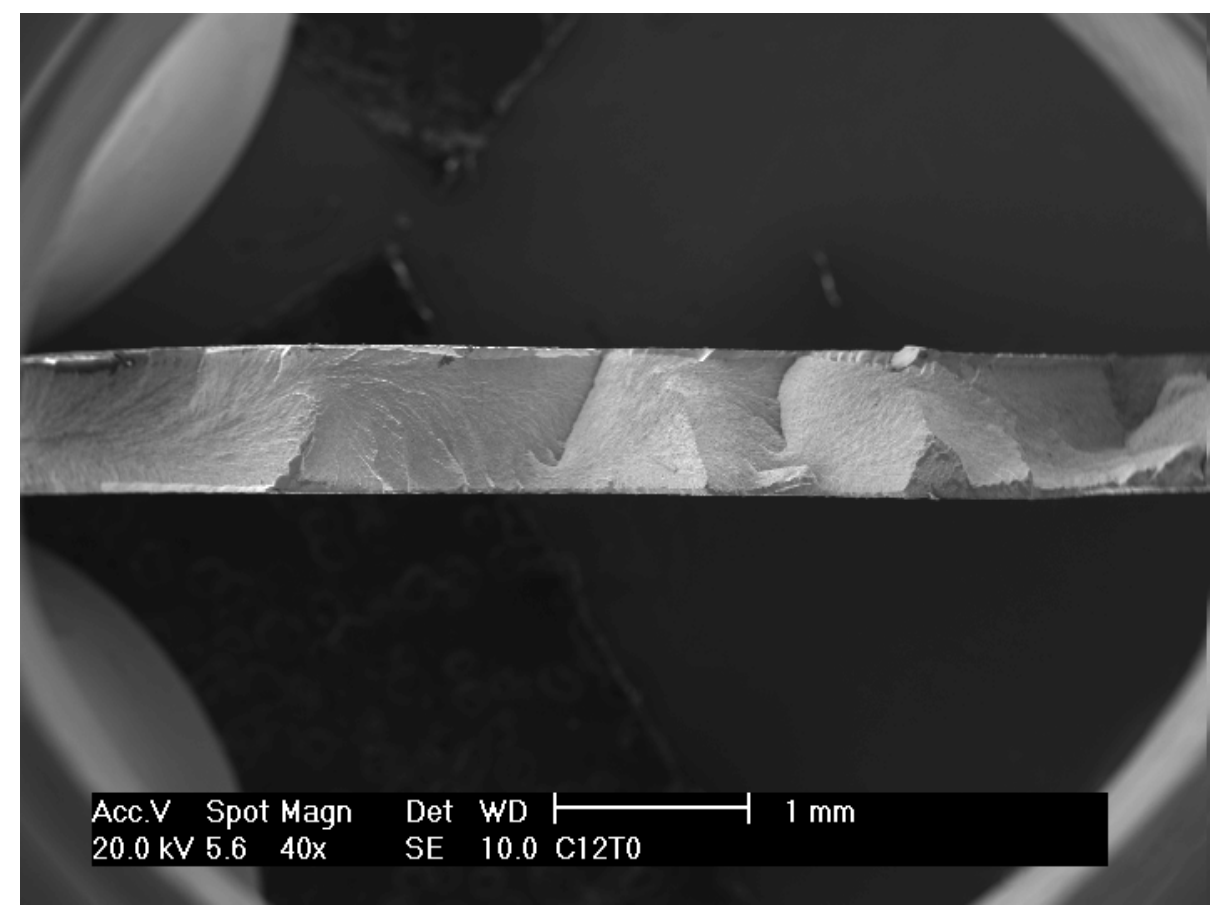

Figura 5.38 Superfície fraturada em ensaio de torção da amostra C12TO, mostrando fratura frágil com desvios. MEV. 40X.

\subsection{RESULTADOS DOS ENSAIOS DE TRAÇÃO.}

Os ensaios de tração foram executados conforme descrito no item 4.5.3 do capítulo anterior, com o objetivo de verificar a eficiência da junta soldada em relação ao metal de base e os efeitos da variação da resistência mecânica no alongamento do material, em função dos diversos parâmetros de soldagem testados.

\subsubsection{Influência dos Parâmetros de Testes nos Ensaios de Tração.}

Os corpos de prova submetidos aos ensaios de tração foram confeccionados conforme item 4.5.3 e norma ASTM SA-370 ${ }^{(60)}$. Os ensaios de tração foram realizados com uma velocidade de tração de $5 \mathrm{~mm} / \mathrm{s}$ e os resultados estão relacionados na tabela 5.36 a seguir. 
Tabela 5.36 Resultados dos Ensaios de Tração.

\begin{tabular}{|c|c|c|c|c|c|c|c|c|c|c|c|c|}
\hline \multicolumn{13}{|c|}{ Resultados dos Ensaios de Tração } \\
\hline \multirow{3}{*}{$\begin{array}{l}\text { Parâ- } \\
\text { metro }\end{array}$} & \multirow{3}{*}{$\begin{array}{c}\text { Identif. } \\
\text { do } \\
\text { c.d.p. }\end{array}$} & \multirow[t]{2}{*}{ LE } & \multirow[t]{2}{*}{ LR } & \multirow[t]{2}{*}{$\mathrm{LR} / \mathrm{LR}_{\mathrm{MB}}$} & \multirow[t]{2}{*}{$\varepsilon$} & \multicolumn{3}{|c|}{ Alongamento em $50 \mathrm{~mm}$} & \multicolumn{3}{|c|}{ Local da Fratura } & \multirow[t]{3}{*}{ Característica da Fratura } \\
\hline & & & & & & $\mathrm{L}_{\mathrm{i}}$ & $\mathrm{L}_{\mathrm{f}}$ & $\Delta \mathrm{L}$ & LCS & $\mathrm{ZAC}$ & MB & \\
\hline & & $\mathrm{MPa}$ & $\mathrm{MPa}$ & $\%$ & $\mathrm{MPa}$ & $\mathrm{mm}$ & $\mathrm{mm}$ & $\%$ & & & & \\
\hline \multirow{5}{*}{ A1 } & A11TR & $1.301,0$ & $1.427,0$ & 96,42 & $184.584,0$ & 50,0 & 51,7 & 3,4 & $\mathrm{X}$ & $\mathrm{X}$ & - & Reta e a $45^{\circ}$. \\
\hline & $\mathrm{A} 12 \mathrm{TR}$ & $1.385,0$ & $1.483,0$ & 100,20 & $217.267,0$ & 50,0 & 51,7 & 3,3 & $\mathrm{X}$ & $\mathrm{X}$ & $\mathrm{X}$ & Diagonal e a $45^{\circ}$. \\
\hline & A13TR & $1.276,0$ & $1.387,0$ & 93,72 & $233.484,0$ & 49,8 & 50,9 & 2,1 & $\mathrm{X}$ & $\mathrm{X}$ & $\mathrm{X}$ & Diagonal e irregular. \\
\hline & $\mu \mathrm{A} 1$ & $1.320,7$ & $1.432,3$ & 96,78 & $211.778,3$ & 49,9 & 51,4 & 2,9 & - & - & - & - \\
\hline & $\sigma \mathrm{A} 1$ & 57,1 & 48,2 & - & $24.907,8$ & 0,1 & 0,5 & 0,7 & - & - & - & - \\
\hline \multirow{5}{*}{ A2 } & $\mathrm{A} 21 \mathrm{TR}$ & $1.328,0$ & $1.427,0$ & 96,42 & $211.277,0$ & 50,1 & 51,4 & 2,5 & - & - & $\mathrm{X}$ & Reta e a $45^{\circ}$. \\
\hline & A22TR & $1.314,0$ & $1.423,0$ & 96,15 & $210.629,0$ & 49,7 & 51,3 & 3,2 & $\mathrm{X}$ & $\mathrm{X}$ & $\mathrm{X}$ & Diagonal e irregular. \\
\hline & A23TR & $1.320,0$ & $1.439,0$ & 97,23 & $209.738,0$ & 49,9 & 51,2 & 2,6 & $\mathrm{X}$ & $\mathrm{X}$ & - & Reta e a $45^{\circ}$. \\
\hline & $\mu \mathrm{A} 2$ & $1.320,7$ & $1.429,7$ & 96,60 & $210.548,0$ & 49,9 & 51,3 & 2,8 & - & - & - & - \\
\hline & $\sigma \mathrm{A} 2$ & 7,0 & 8,3 & - & 772,7 & 0,2 & 0,1 & 0,4 & - & - & - & - \\
\hline \multirow{5}{*}{ A3 } & A31TR & $1.236,0$ & $1.426,0$ & 96,35 & $220.616,0$ & 50,1 & 52,1 & 4,0 & & & $\mathrm{X}$ & Reta e a $45^{\circ}$. \\
\hline & $\mathrm{A} 32 \mathrm{TR}$ & $1.308,0$ & $1.412,0$ & 95,41 & $217.154,0$ & 50,2 & 51,6 & 2,8 & $\mathrm{X}$ & $X$ & $\mathrm{X}$ & Diagonal e irregular. \\
\hline & A33TR & $1.298,0$ & $1.420,0$ & 95,95 & $239.034,0$ & 49,8 & 51,5 & 3,4 & & & $\mathrm{X}$ & Reta e a $45^{\circ}$. \\
\hline & $\mu \mathrm{A} 3$ & $1.280,7$ & $1.419,3$ & 95,90 & $225.601,3$ & 50,0 & 51,7 & 3,4 & - & - & - & - \\
\hline & $\sigma \mathrm{A} 3$ & 39,0 & 7,0 & - & $11.761,1$ & 0,2 & 0,3 & 0,6 & - & - & - & - \\
\hline \multirow{5}{*}{ B1 } & B11TR & $1.331,0$ & $1.430,0$ & 96,62 & $213.650,0$ & 49,8 & 51,6 & 3,6 & & & $\mathrm{X}$ & Reta e a $45^{\circ}$. \\
\hline & $\mathrm{B} 12 \mathrm{TR}$ & $1.288,0$ & $1.393,0$ & 94,12 & $216.192,0$ & 49,8 & 51,2 & 2,8 & $\mathrm{X}$ & $\mathrm{X}$ & $\mathrm{X}$ & Diagonal e irregular. \\
\hline & B13TR & $1.311,0$ & $1.434,0$ & 96,89 & $226.091,0$ & 49,8 & 51,1 & 2,6 & $\mathrm{X}$ & $\mathrm{X}$ & $\mathrm{X}$ & Diagonal e irregular. \\
\hline & $\mu \mathrm{B} 1$ & $1.310,0$ & $1.419,0$ & 95,88 & $218.644,3$ & 49,8 & 51,3 & 3,0 & - & - & - & - \\
\hline & $\sigma \mathrm{B} 1$ & 21,5 & 22,6 & - & $6.573,1$ & 0,0 & 0,3 & 0,5 & - & - & - & - \\
\hline \multirow{5}{*}{ B3 } & B31TR & $1.277,0$ & $1.380,0$ & 93,24 & $196.809,0$ & 50,0 & 51,4 & 2,8 & - & - & $\mathrm{X}$ & Reta e a $45^{\circ}$. \\
\hline & B32TR & $1.299,0$ & $1.420,0$ & 95,95 & $200.747,0$ & 50,1 & 51,7 & 3,2 & - & - & $\mathrm{X}$ & Reta e a $45^{\circ}$. \\
\hline & B33TR & $1.305,0$ & $1.427,0$ & 96,42 & $216.652,0$ & 50,0 & 51,4 & 2,8 & $\mathrm{X}$ & $\mathrm{X}$ & - & Diagonal e irregular. \\
\hline & $\mu \mathrm{B} 3$ & $1.293,7$ & $1.409,0$ & 95,20 & $204.736,0$ & 50,0 & 51,5 & 2,9 & - & - & - & - \\
\hline & $\sigma \mathrm{B} 3$ & 14,7 & 25,4 & - & $10.505,7$ & 0,1 & 0,2 & 0,2 & - & - & - & - \\
\hline \multirow{5}{*}{$\mathrm{C} 1$} & C11TR & $1.314,0$ & $1.435,0$ & 96,96 & $208.154,0$ & 50,7 & 51,4 & 1,4 & $\mathrm{X}$ & - & - & Reta e plana. \\
\hline & $\mathrm{C} 12 \mathrm{TR}$ & $1.353,0$ & $1.508,0$ & 101,89 & $211.221,0$ & 50,9 & 53,1 & 4,3 & $\mathrm{X}$ & $\mathrm{X}$ & - & Reta e plana. \\
\hline & C13TR & $1.333,0$ & $1.475,0$ & 99,66 & $207.562,0$ & 50,9 & 52,5 & 3,0 & $\mathrm{X}$ & $\mathrm{X}$ & - & Reta e plana. \\
\hline & $\mu \mathrm{C} 1$ & $1.333,3$ & $1.472,7$ & 99,50 & $208.979,0$ & 50,8 & 52,3 & 2,9 & - & - & - & - \\
\hline & $\sigma \mathrm{C} 1$ & 19,5 & 36,6 & - & $1.964,1$ & 0,1 & 0,9 & 1,5 & - & - & - & - \\
\hline \multirow{5}{*}{$\mathrm{C} 3$} & $\mathrm{C} 31 \mathrm{TR}$ & $1.285,0$ & $1.429,0$ & 96,55 & $196.402,0$ & 50,1 & 52,1 & 4,0 & - & - & $\mathrm{X}$ & Meia lua e a $45^{\circ}$ \\
\hline & $\mathrm{C} 32 \mathrm{TR}$ & $1.302,0$ & $1.427,0$ & 96,42 & $199.634,0$ & 49,9 & 52,2 & 4,5 & - & - & $\mathrm{X}$ & Meia lua e a $45^{\circ}$ \\
\hline & C33TR & $1.263,0$ & $1.446,0$ & 97,70 & $204.055,0$ & 50,0 & 51,8 & 3,5 & $\mathrm{X}$ & $\mathrm{X}$ & $\mathrm{X}$ & Diagonal e irregular. \\
\hline & $\mu \mathrm{C} 3$ & $1.283,3$ & $1.434,0$ & 96,89 & $200.030,3$ & 50,0 & 52,0 & 4,0 & - & - & - & - \\
\hline & $\sigma \mathrm{C} 3$ & 19,6 & 10,4 & - & $3.841,9$ & 0,1 & 0,2 & 0,5 & - & - & - & - \\
\hline \multirow{5}{*}{ D1 } & D11TR & $1.321,0$ & $1.461,0$ & 98,72 & $205.953,0$ & 50,0 & 52,6 & 5,2 & $\mathrm{X}$ & $\mathrm{X}$ & $\mathrm{X}$ & Diagonal e irregular. \\
\hline & D12TR & $1.344,0$ & $1.476,0$ & 99,73 & $211.692,0$ & 50,2 & 52,2 & 4,0 & $X$ & $\mathrm{X}$ & $\mathrm{X}$ & Diagonal e irregular. \\
\hline & D13TR & $1.347,0$ & $1.474,0$ & 99,59 & $227.767,0$ & 50,0 & 52,2 & 4,4 & $\mathrm{X}$ & $\mathrm{X}$ & $\mathrm{X}$ & Diagonal e irregular. \\
\hline & $\mu \mathrm{D} 1$ & $1.337,3$ & $1.470,3$ & 99,35 & $215.137,3$ & 50,1 & 52,3 & 4,5 & - & - & - & - \\
\hline & $\sigma \mathrm{D} 1$ & 14,2 & 8,1 & - & $11.307,8$ & 0,1 & 0,2 & 0,6 & - & - & - & - \\
\hline
\end{tabular}




\begin{tabular}{|c|c|c|c|c|c|c|c|c|c|c|c|c|}
\hline \multicolumn{13}{|c|}{ Resultados dos Ensaios de Tração - Continuação } \\
\hline \multirow{5}{*}{ D2 } & D21TR & $1.333,0$ & $1.462,0$ & 98,78 & $210.971,0$ & 49,8 & 51,9 & 4,1 & $\mathrm{X}$ & $\mathrm{X}$ & $\mathrm{X}$ & Diagonal e irregular. \\
\hline & D22TR & $1.337,0$ & $1.471,0$ & 99,39 & $217.150,0$ & 49,9 & 51,9 & 4,0 & $\mathrm{X}$ & $\mathrm{X}$ & $\mathrm{X}$ & Diagonal e irregular. \\
\hline & D23TR & $1.265,0$ & $1.462,0$ & 98,78 & $244.337,0$ & 49,9 & 51,7 & 3,6 & $\mathrm{X}$ & $\mathrm{X}$ & $\mathrm{X}$ & Diagonal e irregular. \\
\hline & $\mu \mathrm{D} 2$ & $1.311,7$ & $1.465,0$ & 98,99 & $224.152,7$ & 49,9 & 51,8 & 3,9 & - & - & - & - \\
\hline & $\sigma \mathrm{D} 2$ & 40,5 & 5,2 & - & $17.751,1$ & 0,1 & 0,1 & 0,3 & - & - & - & - \\
\hline \multirow{5}{*}{ D3 } & D31TR & $1.306,0$ & $1.408,0$ & 95,14 & $216.072,0$ & 50,0 & 51,8 & 3,5 & - & - & $\mathrm{X}$ & Reta e plana. \\
\hline & D32TR & $1.329,0$ & $1.440,0$ & 97,30 & $206.023,0$ & 50,0 & 51,4 & 2,8 & - & - & $\mathrm{X}$ & Reta e a $45^{\circ}$. \\
\hline & D33TR & $1.283,0$ & $1.375,0$ & 92,91 & $195.570,0$ & 49,9 & 51,0 & 2,2 & $\mathrm{X}$ & $\mathrm{X}$ & - & Reta e a $45^{\circ}$. \\
\hline & $\mu \mathrm{D} 3$ & $1.306,0$ & $1.407,7$ & 95,11 & $205.888,3$ & 50,0 & 51,4 & 2,8 & - & - & - & - \\
\hline & $\sigma \mathrm{D} 3$ & 23,0 & 32,5 & - & $10.251,7$ & 0,1 & 0,4 & 0,6 & - & - & - & - \\
\hline \multirow{5}{*}{$\mathrm{E} 1$} & E11TR & $1.304,0$ & $1.419,0$ & 95,88 & $208.649,0$ & 49,9 & 51,9 & 3,9 & - & - & $\mathrm{X}$ & Meia lua e a $45^{\circ}$. \\
\hline & E12TR & $1.310,0$ & $1.419,0$ & 95,88 & $204.476,0$ & 50,0 & 51,4 & 2,8 & - & - & $\mathrm{X}$ & Reta e a $45^{\circ}$. \\
\hline & E13TR & $1.316,0$ & $1.441,0$ & 97,36 & $199.838,0$ & 50,1 & 51,7 & 3,2 & - & - & $\mathrm{X}$ & Reta e a $45^{\circ}$. \\
\hline & $\mu \mathrm{E} 1$ & $1.310,0$ & $1.426,3$ & 96,37 & $204.321,0$ & 50,0 & 51,7 & 3,3 & - & - & - & - \\
\hline & $\sigma \mathrm{E} 1$ & 6,0 & 12,7 & - & $4.407,5$ & 0,1 & 0,2 & 0,6 & - & - & - & - \\
\hline \multirow{5}{*}{$\mathrm{E} 2$} & E21TR & $1.313,0$ & $1.426,0$ & 96,35 & $205.392,0$ & 50,0 & 51,6 & 3,2 & - & - & $\mathrm{X}$ & Meia lua e a $45^{\circ}$. \\
\hline & E22TR & $1.330,0$ & $1.446,0$ & 97,70 & $205.269,0$ & 50,1 & 51,6 & 3,0 & $X$ & $\mathrm{X}$ & $\mathrm{X}$ & Diagonal e irregular. \\
\hline & E23TR & $1.319,0$ & $1.431,0$ & 96,69 & $208.927,0$ & 50,0 & 51,4 & 2,8 & - & - & $\mathrm{X}$ & Reta e a $45^{\circ}$. \\
\hline & $\mu \mathrm{E} 2$ & $1.320,7$ & $1.434,3$ & 96,91 & $206.529,3$ & 50,0 & 51,5 & 3,0 & - & - & - & - \\
\hline & $\sigma \mathrm{E} 2$ & 8,6 & 10,4 & - & $2.077,4$ & 0,1 & 0,1 & 0,2 & - & - & - & - \\
\hline \multirow{5}{*}{ E3 } & E31TR & $1.317,0$ & $1.426,0$ & 96,35 & $204.502,0$ & 50,0 & 51,6 & 3,2 & - & - & $\mathrm{X}$ & Meia lua e a $45^{\circ}$. \\
\hline & E32TR & $1.308,0$ & $1.405,0$ & 94,93 & $204.878,0$ & 50,0 & 51,1 & 2,2 & - & - & $\mathrm{X}$ & Reta e a $45 \%$ diagonal. \\
\hline & E33TR & $1.290,0$ & $1.403,0$ & 94,80 & $200.509,0$ & 50,0 & 51,9 & 3,8 & - & $\mathrm{X}$ & $\mathrm{X}$ & Reta e a $45^{\circ}$. \\
\hline & $\mu \mathrm{E} 3$ & $1.305,0$ & $1.411,3$ & 95,36 & $203.296,3$ & 50,0 & 51,5 & 3,1 & - & - & - & - \\
\hline & $\sigma \mathrm{E} 3$ & 13,7 & 12,7 & - & $2.421,2$ & 0,0 & 0,4 & 0,8 & - & - & - & - \\
\hline \multirow{5}{*}{ MB } & MB1TR & $1.334,0$ & $1.492,0$ & 100,81 & $212.640,0$ & 50,0 & 54,4 & 8,8 & - & - & $\mathrm{X}$ & Reta, plana e diagonal \\
\hline & MB2TR & $1.312,0$ & $1.472,0$ & 99,46 & $199.681,0$ & 50,0 & 54,3 & 8,6 & - & - & $\mathrm{X}$ & Reta, plana e diagonal \\
\hline & MB3TR & $1.317,0$ & $1.476,0$ & 99,73 & $208.514,0$ & 50,0 & 54,3 & 8,6 & - & - & $\mathrm{X}$ & Reta, plana e diagonal \\
\hline & $\mu \mathrm{MB}$ & $1.321,0$ & $1.480,0$ & 100,00 & $206.945,0$ & 50,0 & 54,3 & 8,7 & - & - & - & - \\
\hline & $\sigma \mathrm{MB}$ & 11,5 & 10,6 & - & $6.620,4$ & 0,0 & 0,1 & 0,1 & - & - & - & - \\
\hline \multirow{5}{*}{ MP } & MP1TR & 463,0 & 575,0 & 38,85 & $214.290,0$ & 50,0 & 60,7 & 21,4 & - & - & $\mathrm{X}$ & Reta e a $45^{\circ}$. \\
\hline & MP2TR & 473,0 & 606,0 & 40,95 & $204.660,0$ & 49,9 & 61,1 & 22,4 & - & - & $\mathrm{X}$ & Diagonal e irregular. \\
\hline & MP3TR & 461,0 & 595,0 & 40,20 & $204.364,0$ & 50,0 & 61,1 & 22,2 & - & - & $\mathrm{X}$ & Reta, plana e diagonal \\
\hline & $\mu \mathrm{MP}$ & 465,7 & 592,0 & 40,00 & $207.771,3$ & 50,0 & 61,0 & 22,0 & - & - & - & - \\
\hline & $\sigma \mathrm{MP}$ & 6,4 & 15,7 & - & $5.647,3$ & 0,1 & 0,2 & 0,5 & - & - & - & - \\
\hline
\end{tabular}

Conforme pode ser observado na tabela 5.36, a resistência à tração média do metal de base da serra de fita foi de $(1.480,0 \pm 10,6) \mathrm{MPa}$, para um alongamento de $(8,7 \pm 0,1 \%)$. Quando comparado com a matéria prima para o metal de base (fita bimetálica), a resistência à tração média é 
reduzida para $(592 \pm 15,7) \mathrm{MPa}$ e o alongamento aumentado para $(22 \pm 0,5) \%$, devido a este material não estar temperado e revenido.

A maior eficiência de junta soldada ( $\left(\mathrm{RR} / \mathrm{LR}_{\mathrm{MB}}\right)$ média de $99,50 \%$, associada a um alongamento médio de 2,9\%, foi apresentado pelo parâmetro $\mathrm{C} 1$. A menor relação $L R / \mathrm{LR}_{\mathrm{MB}}$ média foi de $95,11 \%$, associada a um alongamento de $2,8 \%$, e foi apresentada pelo parâmetro D3. O parâmetro A2 também apresentou um alongamento médio de 2,8\%, que foi o menor valor observado para esta propriedade. O maior alongamento médio foi de 4,5\% e foi apresentado pelo parâmetro D1.

Desta forma, pode ser observado que, embora a resistência à tração da junta soldada topo-a-topo por centelhamento esteja muito próxima da resistência à tração para o metal de base, houve uma redução significativa no alongamento dos c.d.p. de 8,7\% para 4,5\%, em função da soldagem. Este fenômeno pode ser explicado pela alta deformação provocada pela força de recalque e altas temperaturas de soldagem, que fez aumentar a resistência à tração, com prejuízo da ductilidade. Este comportamento está em conformidade com a referência bibliográfica pesquisada ${ }^{(18-19)}$, conforme item 2.7.2.

Os parâmetros D1, D2 e C3 apresentaram as melhores combinações médias LR/LR $\mathrm{MB}_{\mathrm{e}}$ e alongamento, pela ordem em que estão descritos, ou seja, 99,35\% x 4,5\%, 98,99\% x 3,9\%, e 96,89\% x 4,0\%, respectivamente. Nos testes com os parâmetros D1 e D2 foi possível aumentar a eficiência da junta sem prejuízo do alongamento, o que é uma situação desejada. Entretanto, os parâmetros D1 e D2 apresentaram ruptura à tração na região da solda, assim como o C3. Já para o parâmetro E1, que apresentou eficiência de 96,37\% e alongamento de 3,3\%, todas as fraturas aconteceram no metal de base, indicando que a região da solda apresentou resistência superior a 
do metal de base. Com relação ao parâmetro E3, que foi revenido a $650^{\circ} \mathrm{C}$ por $18 \mathrm{~s}$, a eficiência da junta soldada foi de $95,36 \%$ associada a um alongamento de $3,1 \%$, porém este corpo de prova apresentou ruptura na região da solda, provavelmente devido presença de austenita retida, conforme tabela 5.3.

Alterações na intensidade da corrente elétrica não causaram variações significativas na resistência à tração da junta soldada. Analogamente, mudanças na pressão de recalque não resultaram em variações significativas na resistência à tração. Isto está em conformidade com dados publicados na literatura ${ }^{(64)}$.

O limite de resistência à tração médio dos corpos de prova soldadas ficou entre 95,11\% e 99,50\% do limite de resistência à tração médio do metal de base, conforme tabela 5.36. Este resultado superou o relatado na literatura, que menciona a resistência à tração de juntas soldadas por centelhamento de 90 a 94\% da resistência à tração do metal de base ${ }^{(19)}$

Os corpos de prova dos parâmetros D1 e D2 também apresentaram valores médios de resistência à tração elevados, da ordem de 1.470,30 MPa e 1.465,00 MPa, o que representa uma eficiência da junta soldada de 99,35\% e 98,99\%, respectivamente. Porém estas amostras apresentaram alongamentos significativamente maiores em relação às amostras do parâmetro $\mathrm{C} 1$; ou seja, 4,53\% para D1 e 3,91\% para D2, indicando que o revenimento aplicado nestes corpos de prova contribuiu para o aumento da ductilidade dos mesmos. 
O menor limite de resistência à tração médio ficou associado às amostras do parâmetro de

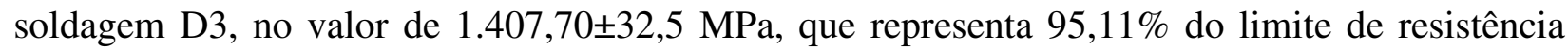
médio do metal de base. Nota-se que para este parâmetro foi utilizado somente um ciclo de revenimento a $650^{\circ} \mathrm{C}$ por $14 \mathrm{~s}$.

Todos os resultados dos ensaios de tração foram considerados satisfatórios, levando-se em conta que o valor médio para a eficiência da junta soldada superou 95\% para todos os parâmetros testados. Pode ser observado, que a soldagem topo-a-topo por centelhamento possui uma alta eficiência da junta soldada, muito próximo do $\mathrm{MB}$, porém foi verificado uma redução significativa no valor do alongamento dos corpos de prova.

\subsubsection{Análises das Fraturas dos Ensaios de Tração.}

Com o objetivo de caracterizar a natureza das fraturas, alguns corpos de prova utilizados nos ensaios de tração foram submetidos à análises no MEV. Conforme pode ser observado nas fotomicrografias das figuras 5.39 a 5.40 a seguir, as amostras analisadas apresentaram características dúcteis e frágeis na superfície fraturada. A região frágil foi caracterizada pela presença de clivagem na superfície da fratura ${ }^{(67-69)}$, conforme pode ser visto nas figuras 5.39 e 5.40. A região dúctil foi caracterizada pela presença de auvéolos na superfície da fratura ${ }^{(66,68,69)}$, conforme pode ser visto também nas figuras 5.39 e 5.40 . 


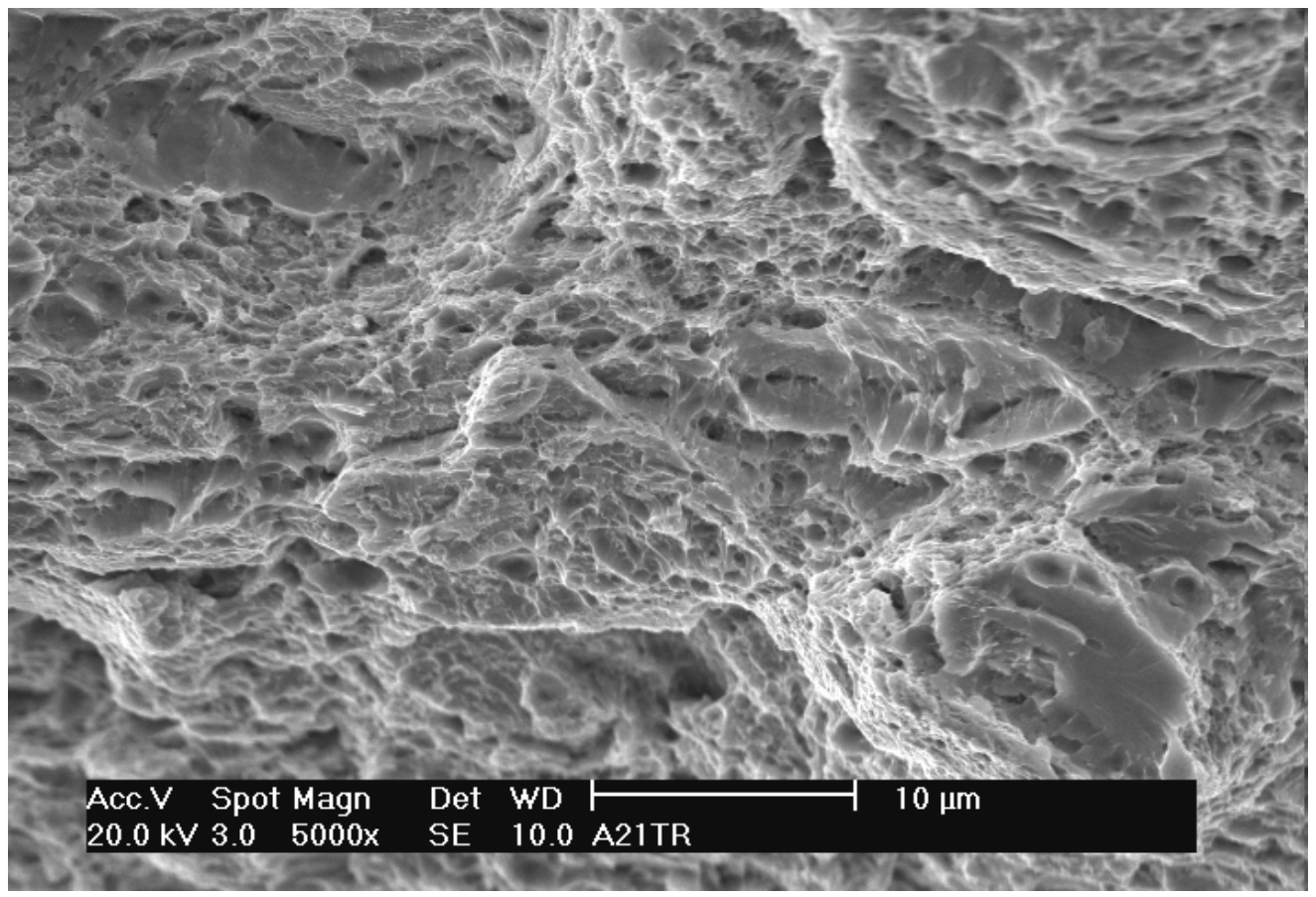

Figura 5.39 Superfície fraturada em ensaio de tração do corpo de prova A21TR, mostrando fratura com aspectos frágil (ao centro) e dúctil (mais a esquerda). MEV. 5.000X.

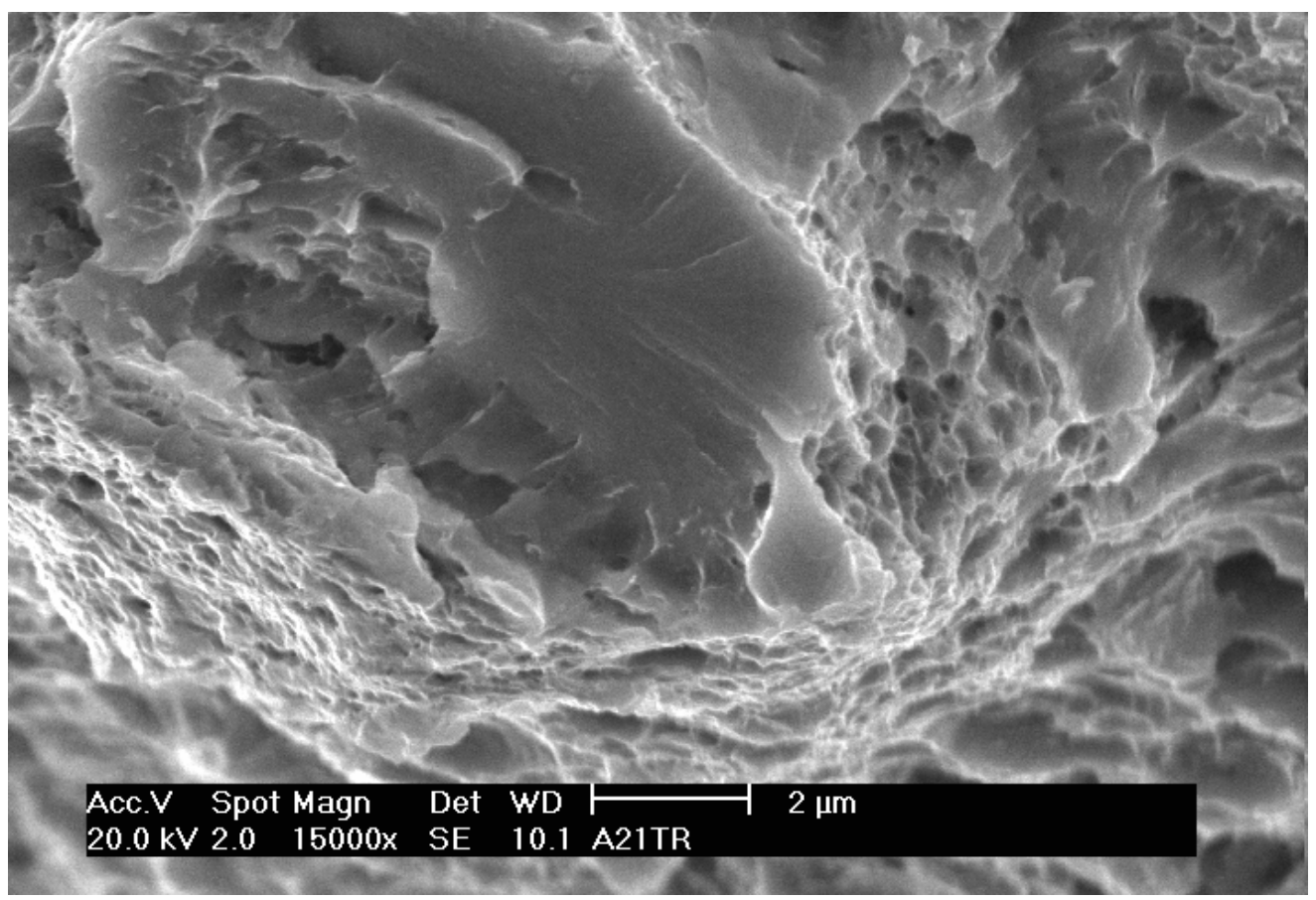

Figura 5.40 Superfície fraturada em ensaio de tração do corpo de prova A21TR, mostrando detalhes da fratura com aspectos frágil (clivagem) circundados por alvéolos (fratura dúctil). MEV. 15.000X. 


\subsection{RESUMO DOS PRINCIPAIS RESULTADOS OBTIDOS CONSIDERANDO-SE OS PARÂMETROS DE SOLDAGEM ESTUDADOS.}

De todos os parâmetros de soldagem estudados neste trabalho, os parâmetros C3, E1 e E2 apresentaram os melhores resultados, considerando-se todas as normas e procedimentos para fabricação e aplicação de serras de fita bimetálica. Dentre estes, o parâmetro E1 foi o único que apresentou resultado satisfatório em todas as análises e testes executados. Dentre as principais características do parâmetro E1 pode ser destacado:

a) Apresentou $100 \%$ de martensita revenida na microestrutura da região da solda (LCS + ZAC) isenta de defeitos.

b) Não apresentou austenita retida nas amostras analisadas transversalmente e longitudinalmente à LCS.

c) Apresentou dureza na região da solda com variações dentro dos padrões especificados para a serra de fita bimetálica.

d) Não afetou a microestrutura e a dureza da ponta dos dentes da região da solda.

e) Apresentou resultados satisfatórios nos ensaios de torção e de tração, com rupturas fora da região da solda.

f) Apresentou resistência à torção (ângulo de fratura) acima dos requisitos especificados.

g) Poderá permitir a racionalização do processo de soldagem, com redução dos atuais três ciclos de revenimento para apenas um.

Vale observar que o parâmetro recomendado A2 apresentou austenita retida em sua microestrutura, o que pode ter influenciado seu resultado ter sido apenas regular nos ensaios de torção e de tração. 


\subsubsection{Verificação do Aumento de Produtividade com Parâmetro E1.}

Foi verificado o aumento de produtividade resultante da economia de tempo de solda mais revenimento em se utilizar o parâmetro E1 em relação ao parâmetro A2 utilizado atualmente, que é recomendado pelo fabricante do equipamento de soldagem.

\section{Parâmetro Recomendado - A2.}

- $\quad \mathrm{N}^{\mathrm{o}}$ de ciclos de revenimento com parâmetro recomendado $\mathrm{A} 2=03$ ciclos.

- Tempo de revenimento com parâmetro recomendado $\mathrm{A} 2=4 \mathrm{~s}+1 \mathrm{~s}+6 \mathrm{~s}+1 \mathrm{~s}+4 \mathrm{~s}=16 \mathrm{~s}$.

Parâmetro Aprovado neste Trabalho - E1.

- $\quad \mathrm{N}^{\mathrm{o}}$ de ciclos de revenimento com parâmetro aprovado $\mathrm{E} 1=01$ ciclo.

- $\quad$ Tempo de revenimento com parâmetro aprovado E1 = 6s.

\section{Economia Projetada com Parâmetro Aprovado neste Trabalho - E1.}

- $\quad$ Tempo de solda atual $=3,1 \mathrm{~s}$

- $\quad$ Tempo de revenimento atual $=16,0 \mathrm{~s}$

- $\quad$ Tempo de solda + revenimento atual $=19,1 \mathrm{~s}$

- Redução no tempo de revenimento com parâmetro E1 = 16,0s - 6,0s = 10,0s

- Economia de tempo de solda + revenimento com parâmetro $\mathrm{E} 1=\frac{10,0 \mathrm{~s}}{19,1 \mathrm{~s}}=0,523$

Economia de tempo no processo de solda + revenimento com parâmetro $\mathrm{E} 1=52,3 \%$ 


\section{CONCLUSÕES.}

A partir das técnicas experimentais utilizadas e dos resultados obtidos pode-se concluir que:

1) A microestrutura na ZAC foi caracterizada por martensita revenida fina em todas as amostras, diferentemente do metal de base, onde a microestrutura apresentou martensita revenida mais grosseira.

2) A LCS apresentou microestrutura um pouco mais grossa em relação à ZAC, em função da temperatura ser maior na interface da solda, devido a maior resistência elétrica da junta neste local.

3) Um aumento na intensidade da corrente elétrica em 14,3\% fez aumentar a dureza na LCS da seção transversal da junta soldada em $8,3 \%$. Uma redução de $14,3 \%$ na intensidade da corrente elétrica, estatisticamente não teve efeito significativo na dureza da LCS.

4) Uma variação na pressão de recalque de $\pm 25 \%$ em relação ao parâmetro recomendado, estatisticamente não teve efeito na dureza da LCS. 
5) O estudo da variação da corrente elétrica e da força de recalque mostrou que o processo pode ser considerado estável com relação à pequenas variações destes parâmetros, que possam ocorrer no dia a dia de uma produção.

6) A menor dureza na região da solda foi medida na LCS para quase todas as amostras, exceto para as amostras dos parâmetros A3 e B3. O aumento da corrente elétrica, conforme parâmetro A3 fez aumentar a energia de soldagem e, consequentemente, a temperatura da junta, fazendo com que a força de recalque expelisse uma quantidade maior de material da interface para fora da junta e isto resultou em uma LCS de maior dureza. O aumento de pressão de recalque, conforme parâmetro B3, praticamente deixou a dureza na LCS nos mesmos valores médios da ZAC.

7) A seção transversal à LCS apresentou diferenciações de dureza em função de microsegregação de silício, molibdênio, cromo, manganês e níquel, que originaram regiões claras e escuras na microestrutura. As regiões de cor escura possuem dureza média de aproximadamente $12 \%$ maior que as regiões de cor clara.

8) O revenimento da junta soldada reduziu a dureza da ZAC em aproximadamente $34 \%$. Da mesma forma, o revenimento reduziu a dureza e a resistência à tração da área soldada (LCS) em aproximadamente $32 \%$ e $10 \%$, respectivamente.

9) Aumentando-se a temperatura ou o tempo de revenido, resultou em redução da dureza na LCS. A menor dureza média na LCS foi de $(470,0 \pm 12,3)$ HV e foi obtida com a temperatura de revenido de $650^{\circ} \mathrm{C}$ e tempo de 18 s (parâmetro E3). 
10) A dureza média na ZAC para todos os parâmetros testados, exceto $C 1$, foi de $(512,28 \pm 10,25)$ HV. Quando comparado com a dureza média na LCS de $(491,46 \pm 9,75)$ HV pode-se observar que a dureza na ZAC foi em média $4 \%$ maior que na LCS.

11) A redução de dureza na LCS em relação à ZAC foi provavelmente devido à microsegregação de elementos de liga nas regiões escuras da ZAC, que fez aumentar sua dureza.

12) A dureza média no $\mathrm{MB}$ de uma região próxima à interface com a ZAC para todos os parâmetros testados, exceto C1, foi de $(484,98 \pm 6,62) \mathrm{HV}$. Quando comparado com a dureza média na LCS de $(491,46 \pm 9,75)$ HV pode-se observar que a dureza na LCS foi praticamente igual a dureza do MB, para todos os parâmetros testados.

13) A dureza no sentido longitudinal à LCS foi em média 8,8\% menor em relação à dureza no sentido transversal. Isto é devido à deformação das linhas de fluxo do material contra a interface da solda, que produz alongamento dos grãos no sentido contrário ao sentido de laminação da chapa.

14) Os corpos de provas dos parâmetros $\mathrm{C} 1$ e D1, que foram soldados sem revenimento e com revenimento insuficiente, respectivamente, foram reprovados nos testes de torção, pois a maior dureza destes corpos de prova não teve ductilidade suficiente para absorver as solicitações destes testes. 
15) Os ensaios de torção tiveram dois corpos de prova reprovados, por terem rompido na região da solda com ângulo de torção menor que $360^{\circ}$, enquanto que todos os testes de tração foram considerados aprovados, pois apresentaram eficiência da junta soldada superior a 95\%. Porém, houve uma redução considerável no alongamento em comparação com o metal de base, o que pode ser explicado pela utilização de uma distância de recalque maior, que provocou um aumento maior na dureza e resistência mecânica da região da solda.

16) Os resultados dos testes de tração e de torção indicaram que a eficiência da junta soldada é comparável às respectivas resistências do metal de base. Os resultados dos ensaios de tração indicaram uma eficiência da junta soldada mínima de 95,11\%, e os resultados dos ensaios de torção apresentaram eficiência de até 100\% em alguns casos, para alguns parâmetros.

17) O aumento da corrente elétrica e da força de recalque não influenciaram a eficiência da junta soldada nos ensaios de tração.

18) O aumento na força de recalque não fez aumentar a dureza da junta nem a resistência à tração dos corpos de prova de forma significativa, o que está coerente com a literatura pesquisada.

19) As fraturas dos ensaios de torção foram caracterizadas por uma região dúctil de cor clara e outra frágil de cor escura, com predomino das regiões dúcteis para parâmetros que apresentaram menores durezas na LCS. 
20) O processo de soldagem topo-a-topo por centelhamento de serras de fita bimetálica mostrou ser um processo tecnicamente capaz para gerar juntas soldadas de alta eficiência e isentas de defeitos, tais como óxidos, porosidades e trincas.

21) A ponta dos dentes da região da solda não sofreu efeitos das altas temperaturas do processo de soldagem. Não foi observado alteração na microestrutura nem na dureza do material M42 da ponta dos dentes.

22) Considerando-se todos os ensaios realizados, o parâmetro E1 foi o que apresentou melhores resultados entre os parâmetros de soldagem pesquisados. Desta forma, a soldagem de serras de fita bimetálica poderá ser otimizada, reduzindo-se a quantidade de revenimentos pós-soldagem de três estágios para apenas um estágio, sem prejuízo da qualidade e da eficiência da junta soldada. Esta otimização poderá gerar um aumento de produtividade de $52,3 \%$ no tempo de soldagem + revenimento para cada solda realizada. 


\section{SUGESTÕES PARA TRABALHOS FUTUROS.}

1) Pesquisar os resultados obtidos neste trabalho, que foi feito para as serras de fita bimetálica de $27 \mathrm{~mm}$, para outras dimensões de serras de fita existentes, para verificação dos efeitos dimensionais da seção transversal da fita bimetálica na absorção e dissipação de calor gerado nas operações de soldagem.

2) Pesquisar a formação e dissolução de carbonetos na microestrutura do corpo da serra de fita bimetálica durante a operação de soldagem e revenimento e qual sua influência na qualidade e resistência das juntas soldadas.

3) Pesquisar a influência do calor gerado na soldagem na tenacidade à fratura dos dentes de aço rápido M42.

4) Pesquisar os efeitos do crescimento de grão na linha central da solda proveniente de aquecimento mais intenso durante a soldagem nas propriedades mecânicas da junta soldada.

5) Pesquisar o efeito da força de recalque nas linhas de fluxo das regiões claras e escuras da ZAC, que fazem aumentar a dureza e reduzir o alongamento da região da solda. 
6) Pesquisar as causas que deram origem à austenita retida presente em algumas amostras soldadas e seu efeito na tenacidade e ductilidade da solda.

7) Pesquisar a redução de dureza da linha central da solda em relação à ZAC com relação à descarbonetação.

8) Pesquisar o comportamento do aço D-6a nas operações de tratamento térmico póssoldagem com relação à fragilidade ao revenido.

9) Estudar os efeitos da soldagem topo-a-topo por centelhamento na resistência à fadiga e tenacidade de juntas soldadas de serras de fita bimetálica. 


\section{REFERÊNCIAS BIBLIOGRÁFICAS.}

1. Informações via e-mail do Gerente de Marketing da Simonds International - EUA - Eric Pfeiffer. E-mail: epfeiffer@simondsint.com. Comunicação pessoal.

2. SIMONDS INTERNATIONAL. Catálogo Técnico de Serras de Fitas. EUA. Rev. 04/2004. 2004, p.13-16. Home page: www.simondsint.com.

3. HOPPER, P.B. Making a Great Set of Teeth. Tool Technology. Industrial Distribution; 88,4; ABI/INFORM Global, April 1999, p.C22-C36.

4. THEIS PRECISION STEEL CORPORATION - USA. Home page: www.theis-usa.com. Product List. Electron Beam Welding (BAR-COMP®). Saw Products.

5. WIKUS-Sägenfabrik - Germany. Catálogo Técnico de Serras de Fitas, 2001. p.18-19. Home page: $\underline{\text { www.wikus.de. }}$

6. SIMONDS INTERNATIONAL - USA. Metallurgical Department. Laboratory Inspection Report. Bill Logan - Metallurgical Engineer. Trabalho não publicado. 10.10.05. E-mail: blogan@simondsint.com.

7. WESPA-METALLSÄGENFABRIK, SIMONDS INDUSTRIES GmbH - Germany. Grundsatzuntersuchung. Laborkontrolle. Christof Peter - Qualitätsicherungsleiter. Trabalho não publicado. 22.02.06. E-mail: peterc@wespa-simonds.de.

8. Informações via e-mail do Gerente de Qualidade da Simonds International - EUA - Eng ${ }^{\circ}$ Salvatore Santoro. E-mail: ssantoro@simondsint.com. Comunicação pessoal.

9. Informações via e-mail do Especialista em Soldagem da Simonds International - EUA - Eng ${ }^{\circ}$ Edward Lashua. E-mail: elashua@ simondsint.com. Comunicação pessoal.

10. BRANDI, S.D. Soldagem por Resistência. In: Soldagem - Processos e Metalurgia. Editora Edgard Blücher Ltda, 1995, p.217-242.

11. OKUMURA, T.; TANIGUCHI, C. Processos de Soldagem e Corte. In: Engenharia de Soldagem e Aplicações. LTC, Rio de Janeiro, 1982, p.41-44.

12. MODENESI, P. J.; MARQUES, P.V. Processos de Soldagem por Deformação. In: Soldagem I - Introdução aos Processos de Soldagem. Universidade Federal de Minas Gerais. Departamento de Engenharia Metalúrgica, Belo Horizonte, novembro de 2000, p. 33-37. www.infosolda.com.br. 
13. BRACARENSE, A. Q. Processo de Soldagem por Resistência - Universidade Federal de Minas Gerais. Escola de Engenharia. Programa de Pós-Graduação em Engenharia Mecânica. Belo Horizonte, maio de 2000. www.infosolda.com.br.

14. MARQUES, P. V.; MODENESI, P. J.; BRACARENSE, A. Q.. Soldagem - Fundamentos e Tecnologia. Editora UFMG, Belo Horizonte, 2005, p. 293-305.

15. LINNERT, G. E.. Welding Methods and Processes. In: Welding Mettalurgy, Carbon and Alloy Steels, Third Edition, Volume 1, Fundamentals, Published by American Welding Society, March 1965, p.135-143.

16. MÜLLER, A. Fundamentos da Técnica de Soldagem por Resistência e sua Aplicação na Prática. LBM Máquinas e Equipamentos de Solda Ltda. Trabalho não publicado. 2002, p.2-8.

17. SAVAGE, W. F. Flash Welding - The Process and Applications. Welding Journal, March 1962, p. 227-237.

18. AMERICAN WELDING SOCIETY. Flash, Upset, and Percussion Welding. In: Welding Handbook - Eighth Edition - Volume 2 - Welding Processes, 1991, p. 582-609.

19. SAVAGE, W. F. Flash Welding - Process Variables and Weld Properties. Welding Journal, March 1962, 109-s-119-s.

20. AMERICAN SOCIETY FOR METALS. Flash and Friction Welding. In: Metals Handbook $8^{\text {th }}$ Edition - Vol. 6 - Welding and Brazing, August 1971, p. 485-506.

21. NIPPES, E. F.; SAVAGE, W. F.; GROTKE, G.; ROBELOTTO, S. M.. Study of the Cooling Rates in Flash Welds in Steel. Welding Journal, July 1954, p.339-s-362-s.

22. SULLIVAN, J. F.; SAVAGE, W. F.. Effect of Phase Control During Flashing on Flash Weld Defects. Welding Journal 50 (5), May 1971, p.213-s-221-s.

23. Informações via e-mail do Engenheiro de Projetos da Ideal Werk - GmbH - Alemanha Eng ${ }^{\circ}$ Dieter Lasarz. E-mail: lasarz@ideal-werk.com. Comunicação pessoal.

24. RILEY, J.J., "Flash-Butt Welding - Welding Technique and Variables in Welding Low Alloy Steels," Ibid., 24 (1), Research Suppl., 12-s to 24-s (1945).

25. GROVER, H.J.; BENNET, R.W.; FOLEY, G.M.. Fatigue Properties of Flash Welds. Welding Journal 24 (11), Welding Research Supplement, November 1945, p. 599-s-617-s.

26. CETINKAYA, C.; ARABACI, U.. Flash Butt Welding Application on 16MnCr5 Chain Steel and Investigations of Mechanical Properties, Elsevier - Science Direct, February 2005, p.1-9.

27. AMERICAN WELDING SOCIETY. Flashing Welding. In: Welding Handbook - Eighth Edition - Volume 1 - Welding Technology, p.17-18. 
28. NIPPES, E. F.; SAVAGE, W. F,; SUZUKI, H.; CHANG, W.H.. A Mathematical Analysis of the Temperature Distribution During Flashing Welding. Welding Journal 34 (6), June 1955, p. 271-s-285-s.

29. TURNER, JR., D.L; PATON, B.E.; LEBEDEV, V.K.; KUTCHUK-YATSENKO, S.I.. Flash Butt Welding of Marine Pipeline Materials. Welding Journal, April 1982, p.17-22.

30. LINNERT, G. E.. Preheating and Postheating. In: Welding Mettalurgy, Carbon and Alloy Steels, Third Edition, Volume 2, Technology, Published by American Welding Society, March 1966, p.158-171.

31. AMERICAN WELDING SOCIETY. Carbon and Low-Alloy Steels. In: Welding Handbook Eighth Edition - Volume 4 - Materials and Applications - Part 2, May, 1998, p. 19-72.

32. BOYER, H. E.; GALL, T. L. Flash Welding. In: Metals Handbook - Desk Edition, American Society for Metals, 1985, p. 30.53-30.55.

33. BARBOSA, C.; DILLE, J.; DELPLANCKE, J.-L.; REBELLO, J.M.A.; ACSELRAD, O.. A microestructural study of flash welded and aged 6061 and 6013 aluminum alloys. Elsevier Materials Characterization 57, 2006, p.187-192.

34. EBRAHIMI, Z.; KRAUSS, G. Mechanisms of Tempered Martensite Embrittlement in Medium-Carbon Steels. Acta Metall., Vol. 32, No. 10, 1984, p. 1767-1777.

35. SKYTTEBOL, A.; JOSEFSON, B.L.; RINGSBERG, J.W.. Fatigue Crack Growth in a Welded Rail under the Influence of Residual Stresses, Elsevier - Science Direct, October 2003, p. 271-285.

36. ASM INTERNATIONAL. Classification and Designation of Carbon and Low-Alloy Steels. In: Metals Handbook - Tenth Edition - Volume 1 - Properties and Selection: Irons, Steels, and High-Performance Alloys, March 1990, p. 140-159.

37. ASM INTERNATIONAL. Carbon and Low-Alloy Steel Sheet and Strip. In: Metals Handbook - Tenth Edition - Volume 1 - Properties and Selection: Irons, Steels, and High-Performance Alloys, March 1990, p. 200-211.

38. CHIAVERINI, V. Aços Carbono e Aços-Liga. Classificação. Propriedades Mecânicas e Fatores de que Dependem. In: Aços e Ferros Fundidos, 4a . Edição, Associação Brasileira de Metais, 1981, p.170-173.

39. ASM INTERNATIONAL. Revised by Philip, T. V. and McCaffrey, T. J.. Ultrahigh-Strength Steels. In: Metals Handbook - Tenth Edition - Volume 1 - Properties and Selection: Irons, Steels, and High Performance Alloys, March 1990, p. 430-438.

40. BECHERER B. A.; WITHEFORD, T. J.. Heat Treating of Ultrahigh-Strength Steels. In: ASM Handbook - Volume 4 - Heat Treating, August 1991, p. 207-213. 
41. ASM INTERNATIONAL. Revised by Kuch, E. R.. Hardenable Carbon and Low-Alloy Steels. In: Metals Handbook - Tenth Edition - Volume 1 - Properties and Selection: Irons, Steels, and High-Performance Alloys, March 1990, p. 451-463.

42. AMERICAN WELDING SOCIETY. Tool and Die Steels. In: Welding Handbook - Eighth Edition - Volume 4 - Materials and Applications - Part 2, May 1998, p. 198-231.

43. ROBERTS, G. A.; CARY, R. A.. Tool Steels - Fourth Edition - American Society for Metals, April, 1980, p. 227-261.

44. CHIAVERINI, V. Aços para Ferramentas e Matrizes. In: Aços e Ferros Fundidos, $4^{\mathbf{a}}$. Edição, Associação Brasileira de Metais, 1981, p. 263-301.

45. HOYLE, G.. High Speed Steels, Butterworth Editor, 1988, p.1-121.

46. ASM INTERNATIONAL. Revised by Burrier Jr., H.; Hardenability of Carbon and LowAlloy Steels. In: Metals Handbook - Tenth Edition - Volume 1 - Properties and Selection: Irons, Steels, and High-Performance Alloys, March 1990, p. 464-484.

47. PORTER, D.A.; EASTERLING, K.E.. Phase Transformation in Metals and Alloys; Second Edition, 1992, p.326-349.

48. KRAUSS, G.. Microstructures, Processing, and Properties of Steels. In: Metals Handbook - Tenth Edition - Volume 1 - Properties and Selection: Irons, Steels, and High-Performance Alloys, ASM International, March 1990, p. 126-139.

49. ASM INTERNATIONAL. Revised by Becherer, B. A. and Witheford, T. J.. Introduction to Heat Treating of Tool Steels. In: ASM Handbook - Volume 4 - Heat Treating. August 1991, p. 711-725.

50. FLETCHER, S. G.; WENDELL, C.R.. ASM Met. Eng. Q., Vol 1, Feb. 1966, p. 146.

51. GRONG, Ø. Metallurgical Modeling of Welding $-2^{\text {nd }}$ Edition, The Institute of Materials, 1997, p.444-453.

52. OKUMURA, T.; TANIGUCHI, C. A Metalurgia da Soldagem. In: Engenharia de Soldagem e Aplicações. LTC, Rio de Janeiro, 1982, p. 49-58.

53. BRANDI, S.D. Metalurgia da Soldagem: Conceitos; Descontinuidades; Soldabilidade de alguns Materiais. In: Soldagem. Coleção Tecnologia Senai, 1997, p. 89-92.

54. BRANDI, S.D. Metalurgia da Soldagem: Conceitos; Descontinuidades; Soldabilidade de alguns Materiais. In: Soldagem. Coleção Tecnologia Senai, 1997, p. 103-123.

55. BRANDI, S.D. Metalurgia da Soldagem: Conceitos; Descontinuidades; Soldabilidade de alguns Materiais. In: Soldagem. Coleção Tecnologia Senai, 1997, p. 115-123. 
56. MADI, V.N.. Transformation Behavior and Weldability of Alloy Rail Steels. Thesis for the Degree of Doctor of Philosophy in Mettalurgical and Materials Engineering in the School of Advanced Studies of Illinois Institute of Technology. Chiccago, May, 1988, p.2.37-2.50.

57. REED-HILL, R. E.. Physical Metallurgy Principles - Second Edition. D. Van Nostrand Company, New York, 1973, p.711-719.

58. LINNERT, G. E.. Welding Alloy Steels. In: Welding Mettalurgy, Carbon and Alloy Steels, Third Edition, Volume 2, Technology, Published by American Welding Society, March 1966, p. 503-517.

59. IDEAL-WERK. Betriebsanleitung Bandsägen-Abbrenn-Schweissmaschine Ideal Typ BAS 100. November, 1998, p. 1-10.

60. AMERICAN SOCIETY FOR TESTING AND MATERIALS. SA-370. Standad Test Methods and Definitions for Mechanical Testing of Steel Products. ASTM. USA. 2001, p. 630-655.

61. BRAMFITT, B. L.. LAWRENCE, S. J.. Metallography and Microstructures of Carbon and Low-Alloy Steels. In: ASM Handbook - Volume 9 - Metallography and Microstructures. ASM International. December 2004, p. 608-626.

62. COSTA NETO, P.L.O.. Comparação de Várias Médias. In: Estatística. Editora Edgard Blücher Ltda. 14ª Reimpressão - 1995, p. 152-174.

63. COSTA NETO, P.L.O.. Testes de Hipóteses. In: Estatística. Editora Edgard Blücher Ltda. 14a Reimpressão - 1995, p. 84-122.

64. KRISHNARAJ, N.; PRASAD RAO, K.; RAMACHANDRAN, G..The Quality of Flash Welded Joints in Mild Steel: A Study on the Effects of Welding Parameters. Welding Research Supplement, June 1993, p.239-s-245-s.

65. VERLAG STAHLSCHLÜSSEL WEGST KG. Stahlschlüssel 20 Jahre. 9. edition 1971, p.4-6

66. DA SILVA, P.S.C.P.. Ductilidade e Fratura Dúctil. In: Comportamento Mecânico e Fratura de Componentes e Estruturas Metálicas, Universidade Federal do Paraná, Curitiba, 1999, p.33-46.

67. DA SILVA, P.S.C.P.. Tenacidade e Fratura Frágil. In: Comportamento Mecânico e Fratura de Componentes e Estruturas Metálicas, Universidade Federal do Paraná, Curitiba, 1999, p.116122.

68. MEYERS, M.A.; CHAWLA, K.K.. Mechanical Behavior of Materials, Prentice-Hall, 1999, p.381-400.

69. HERTZBERG, R.W.. Deformation and Fracture Mechanics of Engineering Materials, $4^{\mathrm{a}}$ Edition, John Wiley \& Sons, Nova Iorque, 1996, p.288-298. 


\section{$9 \quad$ ANEXOS.}

Os seguintes anexos encontram-se nesta seção:

Anexo 01 - Planejamento dos corpos de prova para ensaios de soldagem em serras de fita bimetálica $27 \mathrm{~mm}$.

Anexo 02 - Fotos da máquina de solda Ideal BAS 100. 
ANEXO 01 - Planejamento dos corpos de prova para ensaios de soldagem em serras de fita bimetálica de $27 \mathrm{~mm}$. 


\begin{tabular}{|c|c|c|c|c|c|c|c|c|c|c|c|c|c|c|c|}
\hline \multicolumn{16}{|c|}{ ANEXO 01 - Planejamento dos corpos de prova para ensaios de soldagem em serras de fita bimetálica de $27 \mathrm{~mm}$. } \\
\hline \multicolumn{2}{|c|}{ Variação dos Parâmetros } & \multirow[t]{3}{*}{ Variáveis } & \multirow[t]{3}{*}{ Identif. } & \multirow[t]{3}{*}{ Valores } & \multirow[t]{3}{*}{ Variação } & \multicolumn{6}{|c|}{ Metalografia + Dureza } & \multirow[t]{3}{*}{ Torção } & \multirow[t]{3}{*}{ Identif. } & \multirow[t]{3}{*}{ Tração } & \multirow[t]{3}{*}{ Identif. } \\
\hline \multirow[t]{2}{*}{ Identif. } & \multirow[t]{2}{*}{ Parâmetro } & & & & & \multicolumn{4}{|c|}{ Corpo } & \multirow[t]{2}{*}{ Dente } & \multirow[t]{2}{*}{ Identif. } & & & & \\
\hline & & & & & & $* \mathrm{~L}$ & Identif. & $\mathrm{T}$ & Identif. & & & & & & \\
\hline \multirow{3}{*}{ A } & \multirow{3}{*}{ Corrente Elétrica } & Tap 3 & $\mathrm{~A} 1$ & $\mathrm{~V} 2=3,6 \mathrm{~V}$ & $-14,3 \%$ & 2 & A1L1/2 & 2 & $\mathrm{~A} 1 \mathrm{~T} 1 / 2$ & 2 & $\mathrm{~A} 1 \mathrm{D} 1 / 2$ & 3 & A1TO1/2/3 & 3 & A1TR1/2/3 \\
\hline & & Tap 4 & $\mathrm{~A} 2$ & $\mathrm{~V} 2=4,2 \mathrm{~V}$ & $\mathrm{R}$ & 2 & A2L1/2 & 2 & A2T1/2 & 2 & $\mathrm{~A} 2 \mathrm{D} 1 / 2$ & 3 & A2TO1/2/3 & 3 & A2TR1/2/3 \\
\hline & & Tap 5 & A3 & $\mathrm{V} 2=4,8 \mathrm{~V}$ & $14,3 \%$ & 2 & $\mathrm{~A} 3 \mathrm{~L} 1 / 2$ & 2 & A3T1/2 & 2 & $\mathrm{~A} 3 \mathrm{D} 1 / 2$ & 3 & A3TO1/2/3 & 3 & A3TR $1 / 2 / 3$ \\
\hline \multirow{3}{*}{ B } & \multirow{3}{*}{ Força de Recalque } & 1,5 bar & B1 & - & $-25,0 \%$ & 2 & B1L1/2 & 2 & $\mathrm{~B} 1 \mathrm{~T} 1 / 2$ & - & B1D1/2 & 3 & B1TO1/2/3 & 3 & B1TR1/2/3 \\
\hline & & $2,0 \mathrm{bar}$ & $\mathrm{B} 2$ & - & $\mathrm{R}$ & $* * 0$ & $\mathrm{~B} 2 \mathrm{~L} 1 / 2$ & $* * 0$ & $\mathrm{~B} 2 \mathrm{~T} 1 / 2$ & $* * 0$ & $\mathrm{~B} 2 \mathrm{D} 1 / 2$ & $* * 0$ & В2ТО1/2/3 & $* * 0$ & B2TR1/2/3 \\
\hline & & 2,5 bar & B3 & - & $25,0 \%$ & 2 & B3L1/2 & 2 & B3T1/2 & - & B3D1/2 & 3 & B3TO1/2/3 & 3 & B3TR1/2/3 \\
\hline \multirow{3}{*}{$\mathrm{C}$} & \multirow{3}{*}{ Quantidade de Revenidos } & 0 & $\mathrm{C} 1$ & 0 & & 2 & C1L1/2 & 2 & $\mathrm{C} 1 \mathrm{~T} 1 / 2$ & 2 & $\mathrm{C} 1 \mathrm{D} 1 / 2$ & 3 & $\mathrm{C} 1 \mathrm{TO} 1 / 2 / 3$ & 3 & C1TR1/2/3 \\
\hline & & 3 & $\mathrm{C} 2$ & $\begin{array}{l}\mathrm{T} 1=630^{\circ} \mathrm{C}, \mathrm{t} 1=4 \mathrm{~s}, \mathrm{~T} 1 / \mathrm{T} 2=1 \mathrm{~s} \\
\mathrm{~T} 2=650^{\circ} \mathrm{C}, \mathrm{t} 2=6 \mathrm{~s}, \mathrm{~T} 2 / \mathrm{T} 3=1 \mathrm{~s} \\
\mathrm{~T} 3=620^{\circ} \mathrm{C}, \mathrm{t} 3=4 \mathrm{~s}\end{array}$ & $\mathrm{R}$ & $* * 0$ & $\mathrm{C} 2 \mathrm{~L} 1 / 2$ & $* * 0$ & $\mathrm{C} 2 \mathrm{~T} 1 / 2$ & $* * 0$ & $\mathrm{C} 2 \mathrm{D} 1 / 2$ & $* * 0$ & $\mathrm{C} 2 \mathrm{TO} 1 / 2 / 3$ & $* * 0$ & $\mathrm{C} 2 \mathrm{TR} 1 / 2 / 3$ \\
\hline & & 2 & $\mathrm{C} 3$ & $\begin{array}{l}\mathrm{T} 1=630^{\circ} \mathrm{C}, \mathrm{t} 1=4 \mathrm{~s}, \mathrm{~T} 1 / \mathrm{T} 2=1 \mathrm{~s} \\
\mathrm{~T} 2=650^{\circ} \mathrm{C}, \mathrm{t} 2=6 \mathrm{~s}\end{array}$ & & 2 & $\mathrm{C} 3 \mathrm{~L} 1 / 2$ & 2 & C3T1/2 & - & $\mathrm{C} 3 \mathrm{D} 1 / 2$ & 3 & C3TO1/2/3 & 3 & C3TR $1 / 2 / 3$ \\
\hline \multirow{3}{*}{$\mathrm{D}$} & \multirow{3}{*}{$\begin{array}{l}\text { Temperatura de Revenido } \\
\text { (01 Revenido) }\end{array}$} & $\mathrm{T}=500^{\circ} \mathrm{C}$ & D1 & $\mathrm{T}=500^{\circ} \mathrm{C}, \mathrm{t}=14 \mathrm{~s}$ & - & 2 & D1L1/2 & 2 & $\mathrm{D} 1 \mathrm{~T} 1 / 2$ & - & $\mathrm{D} 1 \mathrm{D} 1 / 2$ & 3 & D1TO1/2/3 & 3 & D1TR1/2/3 \\
\hline & & $\mathrm{T}=550^{\circ} \mathrm{C}$ & $\mathrm{D} 2$ & $\mathrm{~T}=550^{\circ} \mathrm{C}, \mathrm{t}=14 \mathrm{~s}$ & - & 2 & $\mathrm{D} 2 \mathrm{~L} 1 / 2$ & 2 & $\mathrm{D} 2 \mathrm{~T} 1 / 2$ & - & $\mathrm{D} 2 \mathrm{D} 1 / 2$ & 3 & D2TO1/2/3 & 3 & D2TR1/2/3 \\
\hline & & $\mathrm{T}=650^{\circ} \mathrm{C}$ & D3 & $\mathrm{T}=650^{\circ} \mathrm{C}, \mathrm{t}=14 \mathrm{~s}$ & - & 2 & D3L1/2 & 2 & D3T1/2 & 2 & D3D1/2 & 3 & D3TO1/2/3 & 3 & D3TR1/2/3 \\
\hline \multirow{3}{*}{ E } & \multirow{3}{*}{$\begin{array}{l}\text { Tempo de Revenido } \\
\quad(01 \text { revenido })\end{array}$} & $\mathrm{t}=6 \mathrm{~s}$ & E1 & $\mathrm{T}=650^{\circ} \mathrm{C}, \mathrm{t}=6 \mathrm{~s}$ & - & 2 & E1L1/2 & 2 & E1T1/2 & - & E1D1/2 & 3 & E1TO1/2/3 & 3 & E1TR1/2/3 \\
\hline & & $\mathrm{t}=10 \mathrm{~s}$ & E2 & $\mathrm{T}=650^{\circ} \mathrm{C}, \mathrm{t}=10 \mathrm{~s}$ & - & 2 & E2L1/2 & 2 & E2T1/2 & - & E2D1/2 & 3 & E2TO1/2/3 & 3 & E2TR1/2/3 \\
\hline & & $\mathrm{t}=18 \mathrm{~s}$ & E3 & $\mathrm{T}=650^{\circ} \mathrm{C}, \mathrm{t}=18 \mathrm{~s}$ & - & 2 & E3L1/2 & 2 & E3T1/2 & - & E3D1/2 & 3 & E3TO1/2/3 & 3 & E3TR1/2/3 \\
\hline $\mathrm{F}$ & $\begin{array}{l}\text { Ponta do dente de uma } \\
\text { região sem solda. }\end{array}$ & - & $\mathrm{F} 1$ & Sem solda. & - & - & - & - & - & 2 & F1D1/2 & - & - & - & - \\
\hline- & Total de c.d.p. & - & - & - & - & 26 & - & 26 & - & 12 & - & 39 & - & 39 & - \\
\hline
\end{tabular}

R - Parâmetro recomendado conforme tabela 4.5 .

L = Longitudinal à LCS; T = Transversal à LCS.

* Foram feitos ensaios de dureza somente para os parâmetros A1, A2 e A3.

** Não foram feitos ensaios para os parâmetros B2 e C2, pois seus valores são iguais aos do parâmetro A2 (tabela 4.5).

\begin{tabular}{|c|c|}
\hline \multicolumn{2}{|c|}{ Quantidade de Ensaios } \\
\hline Metalografia & 64 \\
\hline * Dureza & 44 \\
\hline Torção & 39 \\
\hline Tração & 39 \\
\hline Total & 186 \\
\hline
\end{tabular}


ANEXO 02 - Equipamento de Soldagem marca Ideal Werk, modelo BAS 100. 


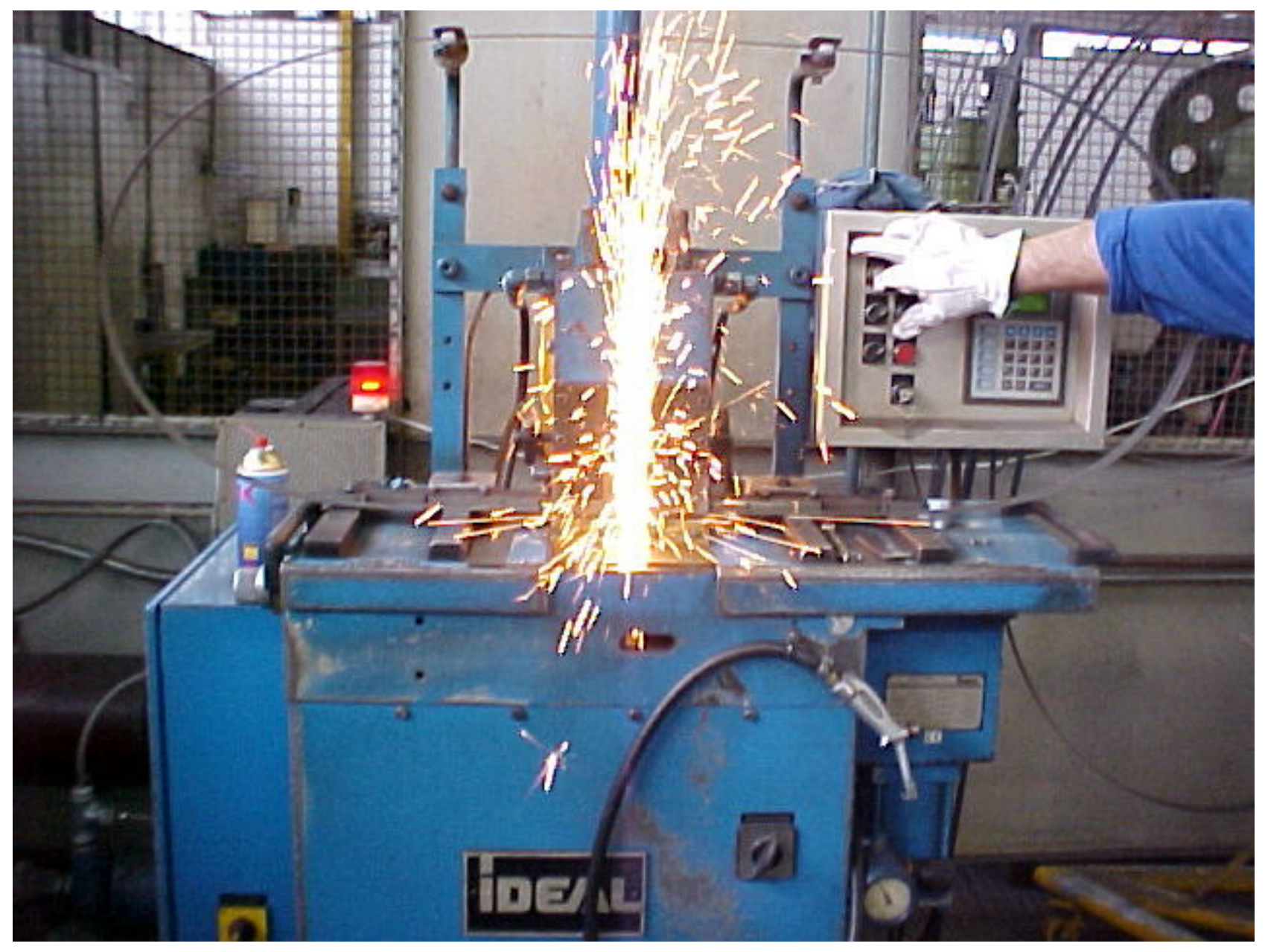

